2008

\title{
Cultural Resources Survey of Fairfield Lake State Park, Freestone County, Texas
}

David M. Yelacic

Gregory J. LaBudde

Center for Archaeological Studies

Jon C. Lohse

Center for Archaeological Studies

Follow this and additional works at: https://scholarworks.sfasu.edu/ita

Part of the American Material Culture Commons, Archaeological Anthropology Commons, Environmental Studies Commons, Other American Studies Commons, Other Arts and Humanities Commons, Other History of Art, Architecture, and Archaeology Commons, and the United States History Commons

Tell us how this article helped you.

This Article is brought to you for free and open access by the Center for Regional Heritage Research at SFA ScholarWorks. It has been accepted for inclusion in Index of Texas Archaeology: Open Access Gray Literature from the Lone Star State by an authorized editor of SFA ScholarWorks. For more information, please contact cdsscholarworks@sfasu.edu. 
Cultural Resources Survey of Fairfield Lake State Park, Freestone County, Texas

Creative Commons License

(c) (1) \& 8

This work is licensed under a Creative Commons Attribution-NonCommercial 4.0 International License 
Cultural Resources Survey of Fairfield Lake State Park, Freestone County, Texas

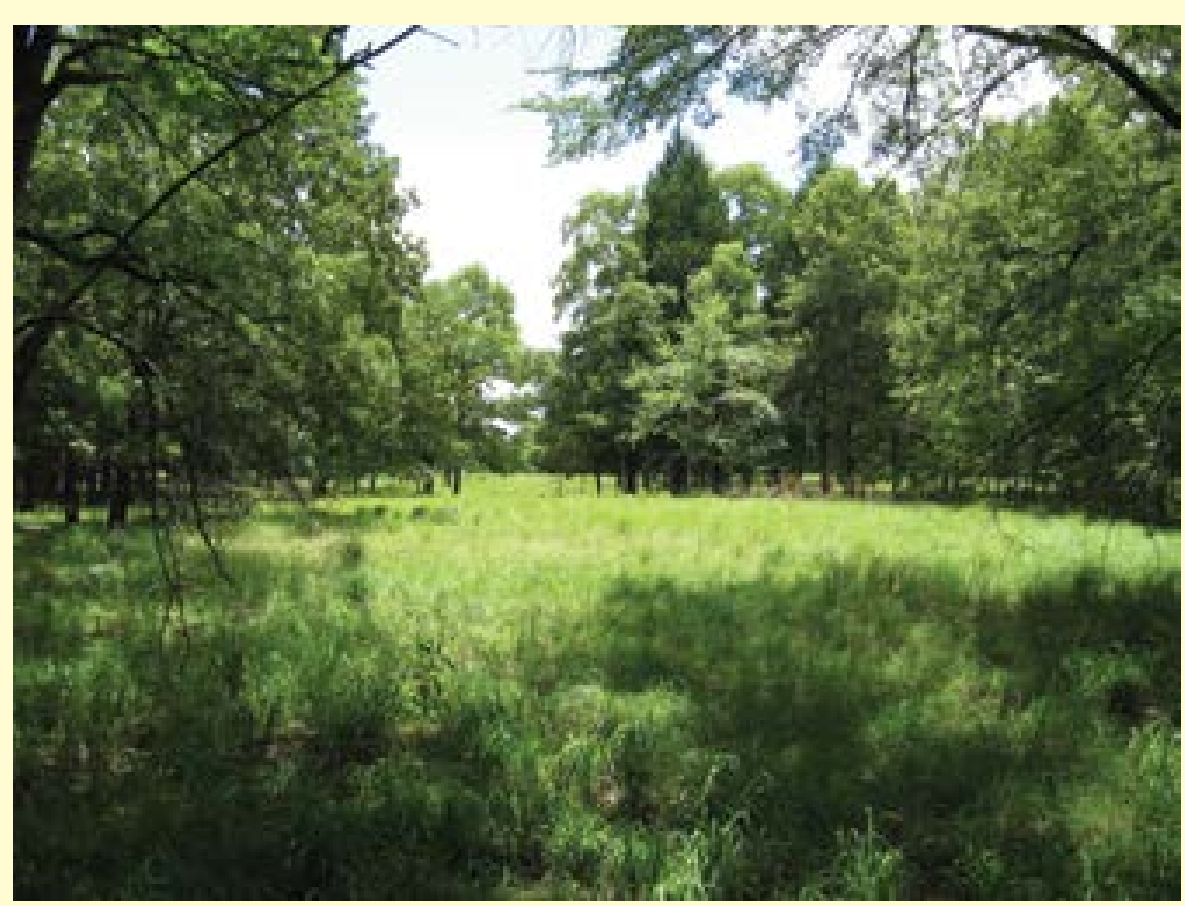

by

David M. Yelacic, Gregory J. LaBudde, and Jon C. Lohse

Principal Investigators: James E. Corbin (1996) and Jon C. Lohse (2008)

\section{TEXAS PARKS AND WILDLIFE}

Archaeological Studies Report No. 15

Center for Archaeological Studies Texas State University-San Marcos 


\title{
Cultural Resources Survey of Fairfield Lake State Park, Freestone County, Texas
}

\author{
by \\ David M. Yelacic, Gregory J. LaBudde, and Jon C. Lohse
}

Principal Investigators:

James E. Corbin (1996) and Jon C. Lohse (2008)

Archaeological Studies Report No. 15

Center for Archaeological Studies

Texas State University-San Marcos

2008 
The following information is provided in accordance with the General Rules of Practice and Procedures, Title 13, Chapter 26, Texas Administrative Code:

1. Type of investigation: Survey of cultural resources.

2. Project name: Cultural Resources Survey of Fairfield Lake State Park, Freestone County, Texas.

3. County: Freestone

4. Principal Investigators: James E. Corbin (1996) and Jon C. Lohse (2008)

5. Name and location of sponsoring agency: Texas Parks and Wildlife Department, 4200 Smith School Road, Austin, Texas, 78744.

6. Published by the Center for Archaeological Studies, Texas State University-San Marcos, 601 University Drive, San Marcos, Texas, 78666-4616 (2008)

Texas State University-San Marcos is a member of the Texas State University System Copyright (C) 2008 by the Center for Archaeological Studies at Texas State University-San Marcos

All rights reserved.

No part of this book may be reproduced or utilized in any form or by any means, electronic or mechanical, including photocopying, recording, or by any information storage and retrieval system without permission in writing.

For further information on this and other publications by the Center for Archaeological Studies, please contact:

Center for Archaeological Studies Texas State University-San Marcos 601 University Drive San Marcos, TX 78666-4616 www.txstate.edu/anthropology/cas/

Editor: Jessica L. Hurley and Brooke Boyer

Cover Photograph: Fairfield Lake State Park

Printed in the United States of America

by

Center for Archaeological Studies, Texas State University-San Marcos 


\section{Management Summary}

\section{Management Objectives}

Fairfield Lake State Park occupies 1,460 acres in Freestone County, approximately five miles northeast of Fairfield, Texas. The land was acquired for lease by Texas Parks and Wildlife Department (TPWD) from Texas Utilities in the 1970s. Under provisions of the Texas Antiquities Code, TPWD is responsible for managing any possible cultural resources on park land. In an effort to begin building an inventory of sites, a cultural resource survey of the park was conducted by Stephen F. Austin State University (SFA) in 1996 under Texas Antiquities Permit No. 1698, granted to Dr. James E. Corbin. The SFA crew that performed the 1996 fieldwork recorded or revisited a total of 34 sites in the park's 1,460 acres. However, due to unforeseen circumstances, this initial assessment was never completed; all of the fieldwork was performed, but analysis, curation, and the completion of the report went unfinished. In 2008, TPWD contracted the Center for Archaeological Studies at Texas State University-San Marcos (CAS) to complete the project. Working under contract with TPWD and the reactivated Permit No. 1698, CAS revisited and reassessed each of the 34 sites, recorded an additional site, completed the report, and finalized the analysis and curation of all documents and artifacts recovered in 1996 and 2008. Fieldwork was performed in June of 2008 by Gregory J. LaBudde, Project Archaeologist, David M. Yelacic, CAS Archaeologist, and Jon C. Lohse, who served as the Principal Investigator for the CAS work.

To assist TPWD Cultural Resource staff and park personnel in effectively managing the cultural resources at the park, CAS classified each site in terms of management priority. In addition to the considerations for site worthiness that are defined in the Texas Antiquities Code, CAS also evaluated each site in terms of its potential eligibility for inclusion to the National Register of Historic Places (NRHP) in the event that any future development or activities might take place at the park under federal permit or with federal funding. The Texas Antiquities Code and National Historic Preservation Act (NHPA) are detailed in Chapter 3 of this report. Each level of site integrity and research potential is described below.

Level 1 sites (41FT280, 41FT408, 41FT409, 41FT470, 41FT481, 41FT482, and 41FT630) are considered to have the highest potential significance in terms of intactness, integrity, and the cultural materials they contain. Level 1 sites are eligible for designations as SALs or nomination to the NRHP. CAS recommends that Level 1 sites be avoided during future park developments if at all possible. If these sites cannot be avoided, CAS recommends that additional fieldwork be carried out to offset the resultant loss of information. Such future work should include archaeological testing and, in the case of historic sites, archival research so that the affected site(s) can be contextualized in local, regional, and state historical developments and events.

Level 2 sites (41FT279, 41FT464, 41FT465, 41FT466, 41FT467, 41FT468, 41FT473, 41FT474, $41 \mathrm{FT} 477,41 \mathrm{FT} 483$, and 41FT485) appear to be intact and retain integrity, although for various reasons 
their potential significance is not fully demonstrated. Therefore, Level 2 sites are of unknown eligibility for designation as SALs or nomination to the NRHP. CAS recommends that if future park developments will impact these sites, additional work should be carried out in advance of those impacts to assess the site's potential significance. In many cases, this additional work might consist merely of archival research (in the case of some historic sites), additional shovel testing, or light, controlled, hand-excavation. Based on this work, recommendations may be made about the need for any additional research to offset the loss of important cultural information that may result from the proposed developments.

Level 3 sites (41FT463, 41FT469, 41FT471, 41FT475, 41FT476, 41FT478, 41FT479, 41FT480, 41FT484, 41FT486, and 41FT488) are considered to have very little to no research potential, but are of unknown eligibility for designation as SALs or nomination to the NRHP for a number of reasons. These include that the sites are on deflated or moderately disturbed landforms, or that they lack an artifact content capable of yielding useful information about historic or prehistoric activities that may have been carried out at these locations. CAS recommends that the THC should review these sites in the event of future impacts.

An assessment of Level 4 was reserved for sites which had been mostly or completely destroyed by recent development, were significantly impacted by erosion, or were entirely deflated. A small number of sites were classified as Level 4, including 41FT472, 41FT487, 41FT496, 41FT497, 41FT498, and 41FT499. Level 4 sites are considered ineligible for designation as SALs or nomination to the NRHP. The primary distinction between Level 3 and 4 sites is that Level 3 sites, while having low research value, remain present and retain evidence of prehistoric or historic activities that were once carried out there. In contrast, at Level 4 sites, all such integrity and evidence is gone. CAS recommends that TPWD be permitted to develop these areas.

To summarize, in the event that future park developments will impact the aforementioned cultural resources, CAS offers the following recommendations. Level 1 sites are considered eligible for listing to the NRHP and/or being designated as SALs and should be avoided to the degree possible or feasible in the context of proposed development. If these sites cannot be avoided, CAS recommends that TPWD conduct additional archaeological and, in the case of historic sites, archival research to mitigate the loss of important cultural information that these sites contain. In the event that Level 2 sites cannot be avoided and will be impacted by future developments, CAS recommends that TPWD conduct additional archaeological and/or archival research to finalize assessments about the potential significance of these sites. This research should focus on assessing whether these sites meet any of the significance or worthiness criteria set forth in the NHPA or the Texas Antiquities Code (see Chapter 3, this report). Based on the results of this work, additional research may or may not be warranted. Level 3 sites are considered to have very little to no research potential, but are of unknown eligibility for designation as SALs or nomination to the NRHP. The THC should review these sites in the event of future impacts. Level 4 sites are not considered eligible for listing to the NRHP or worthy of being designated as SALs. If future developments are proposed that will impact Level 4 sites, CAS recommends that TPWD be granted regulatory clearance to proceed with those activities without further consideration for any potential loss of information that may result from that development. 


\section{Table of Contents}

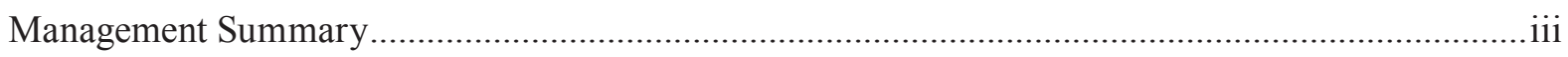

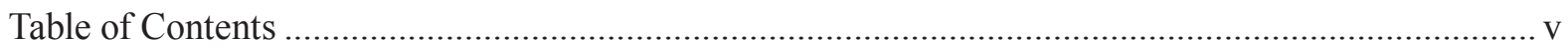

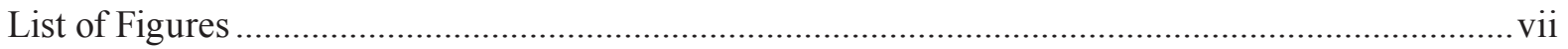

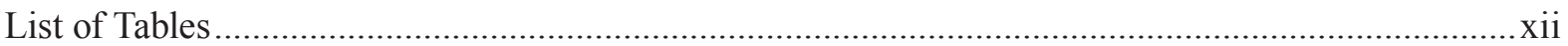

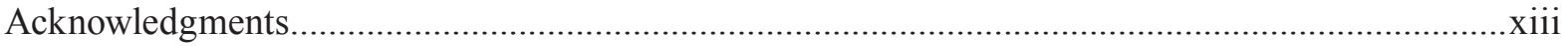

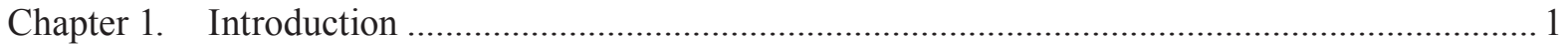

Chapter 2. Project Setting, Cultural Chronology, and Previous Investigations ............................... 5

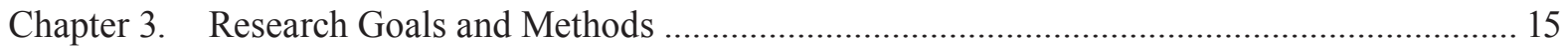

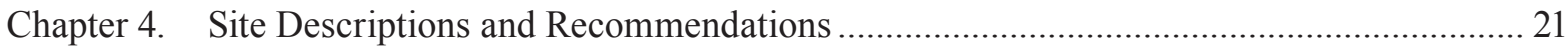

Chapter 5. Management Level and Recommedations..................................................................... 77

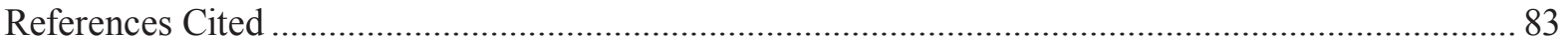

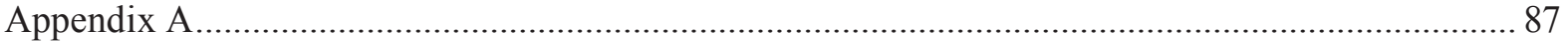

Appendix B ................................................................................................. inside back cover 


\section{List OF Figures}

1-1. Location of Fairfield Lake State Park and survey area of the 1996 project plotted on the Young 7.5' United States Geologic Survey topographic sheet

2-1. Level III Ecoregions map of Texas with Freestone County outlined in red ............................. 6

2-2. Soils found across Fairfield Lake State Park, bounded in yellow (after Janak

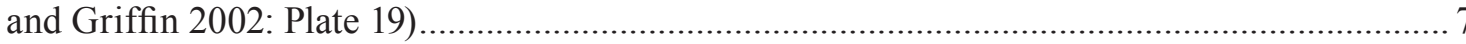

4-1. Southern boundary of site showing the amphitheater, well, and restroom facilities;

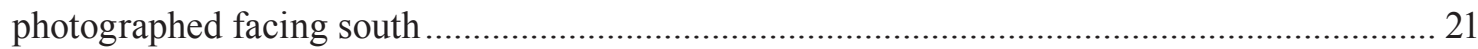

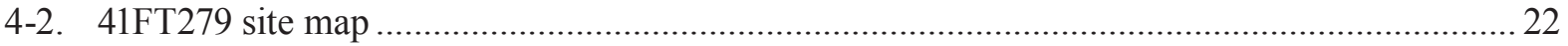

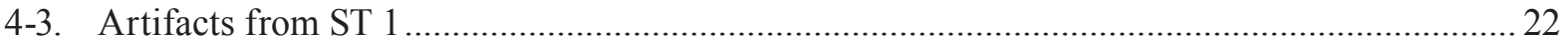

4-4. Profile of ST 2 showing complex, cultural stratigraphy ...................................................... 23

4-5. Overview of site 41FT280; photographed facing east ........................................................... 24

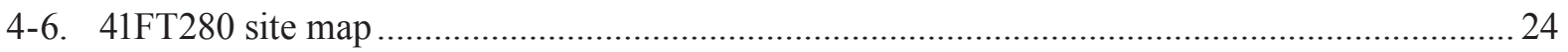

4-7. Low-fired bricks found on the surface near the two depressions ............................................ 25

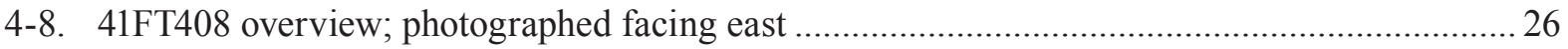

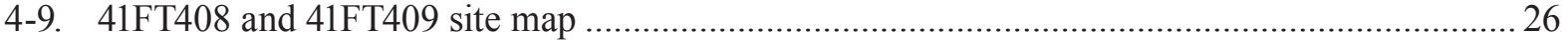

4-10. Intersecting historic road cuts northwest of 41FT409; photographed facing north.................. 27

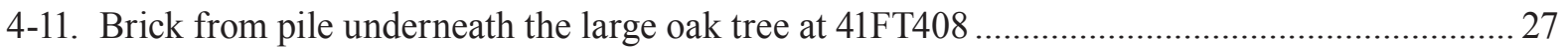

4-12. Overview of 41FT463; photographed facing east ................................................................ 28

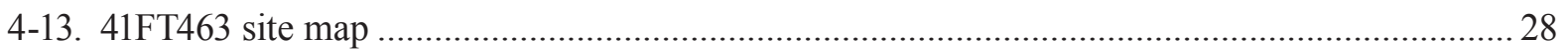

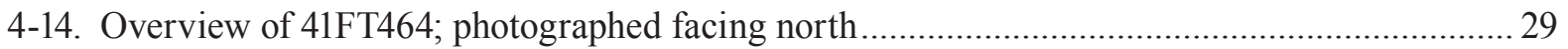

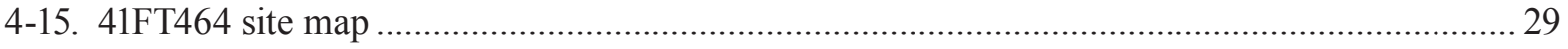

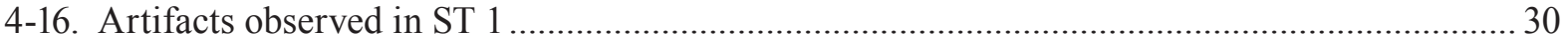

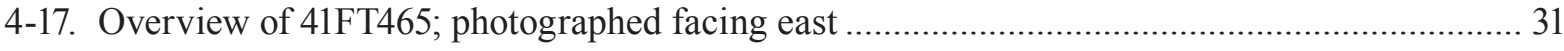

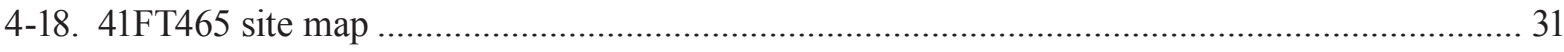

4-19. Gary projectile point recovered from 41FT465 (Lot 1) .......................................................... 32

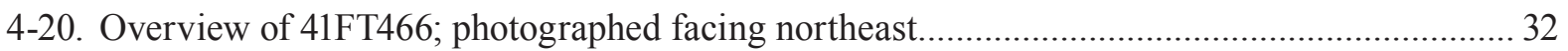




\section{List OF Figures (CONTinued)}

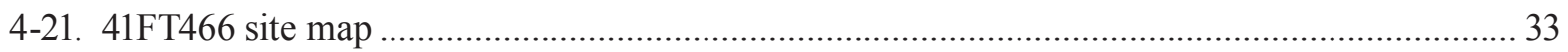

4-22. Overview of 41FT467 showing barbed wire fence; photographed facing north ....................... 34

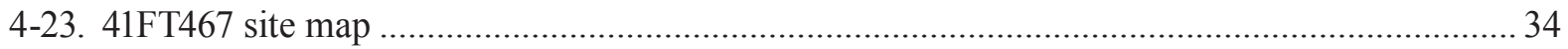

4-24. Overview of 41FT468; photographed facing north ............................................................... 35

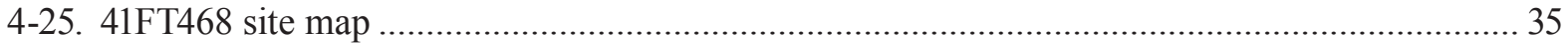

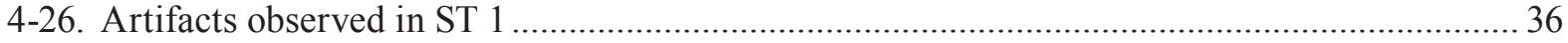

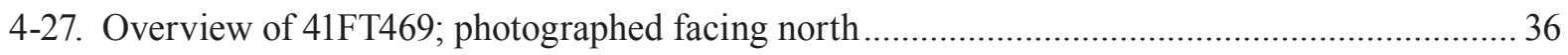

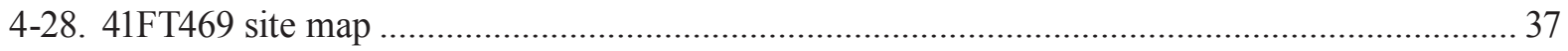

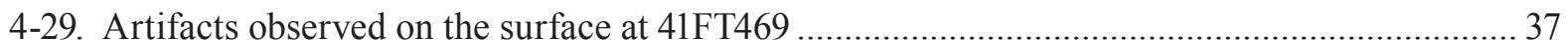

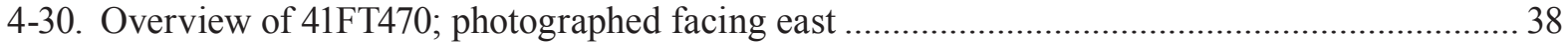

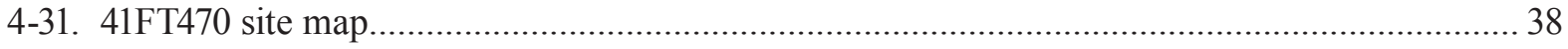

4-32. Pile of ferruginous sandstone rocks; photographed facing southeast....................................... 39

4-33. Overview of 41FT471 and adjacent cut bank; photographed facing east ................................. 40

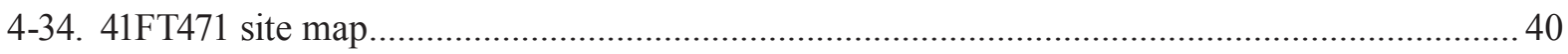

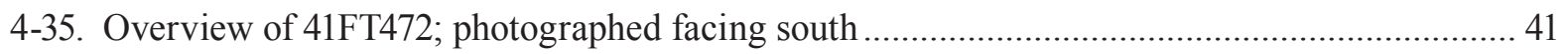

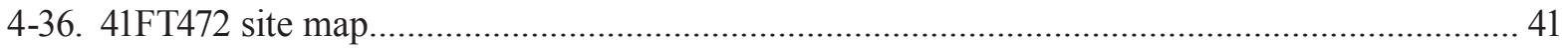

4-37. Overview of parking lot and boat ramp access road; photographed facing

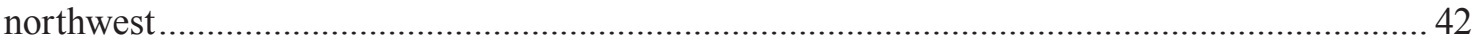

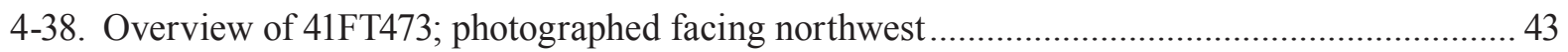

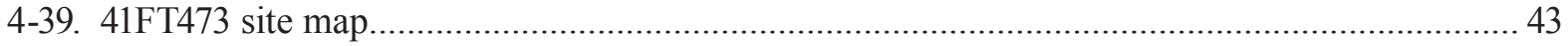

4-40. Overview of 41FT474 featuring miscellaneous metal (far left center) and a depression (far right center); photographed facing east .......................................................... 44

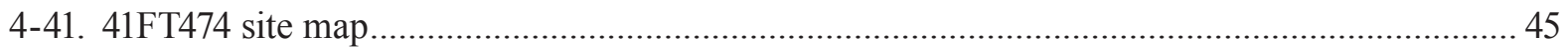

4-42. Depression at 41FT474; photographed facing southeast ........................................................ 45

4-43. Overview of 41FT475; photographed facing southeast ....................................................... 46

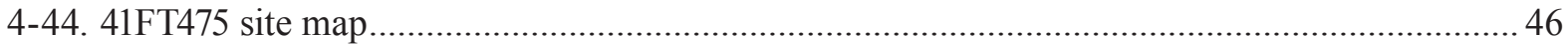




\section{List OF Figures (Continued)}

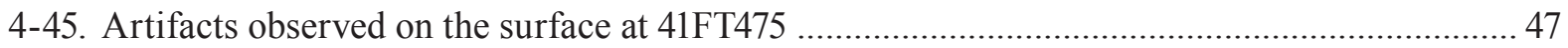

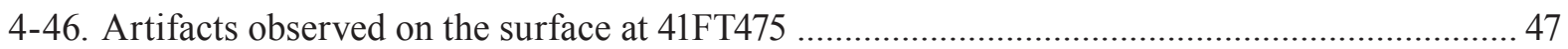

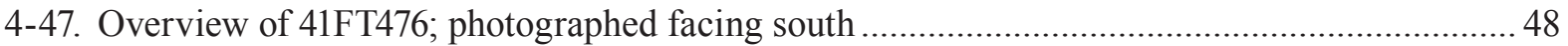

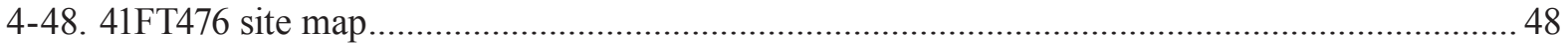

4-49. Overview of 41FT477; photographed facing southeast ........................................................... 49

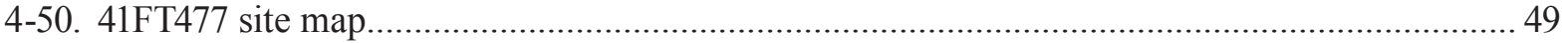

4-51. Overview of 41FT478; photographed facing southeast.................................................... 50

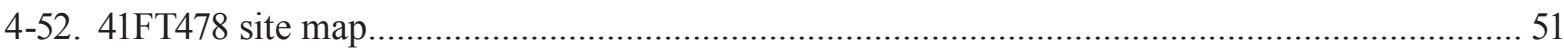

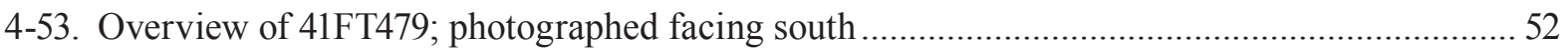

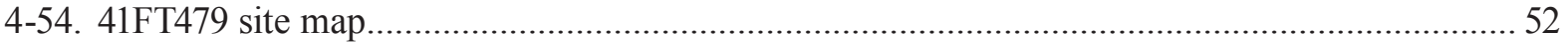

4-55. Overview of 41FT480 featuring thick vegetation; photographed facing west........................... 53

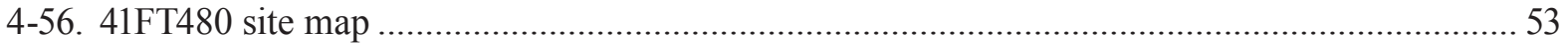

4-57. Overview of 41FT481; photographed facing southeast .......................................................... 54

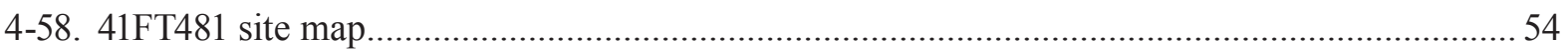

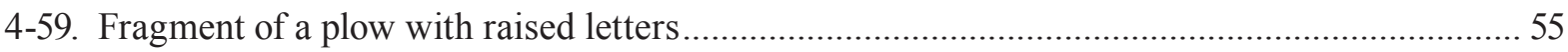

4-60. Overview of 41FT482 with Springfield Camping Area road in the foreground;

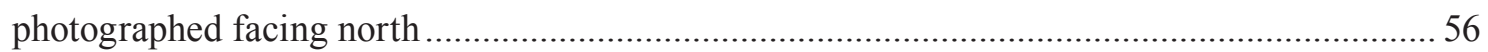

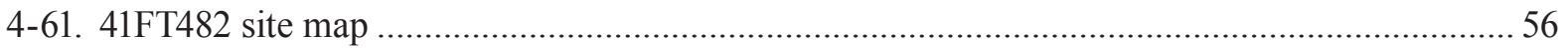

4-62. "Clover's Imperial Medicine” bottle recovered from dry gully (Lot 5) ................................... 57

4-63. Bulldozed mound; photographed facing southwest ................................................................. 58

4-64. Artifacts observed on the surface in the vicinity of the bulldozed mound ..............................58

4-65. Overview of 41FT483 with Primitive Camping Area hiking trail; photographed

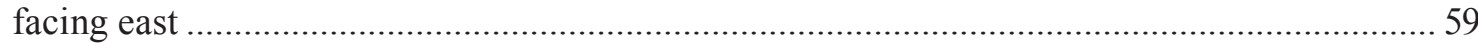

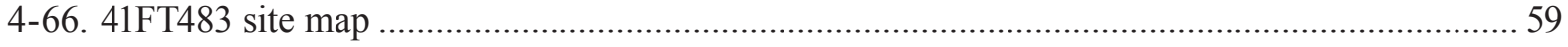

4-67. Nutting stone recovered from the northern portion of 41FT483 (Lot 3) .................................. 60

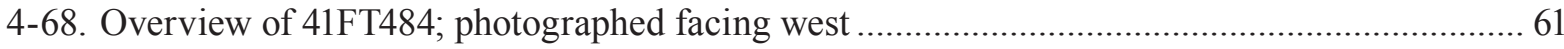




\section{List OF Figures (Continued)}

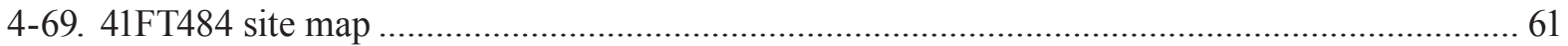

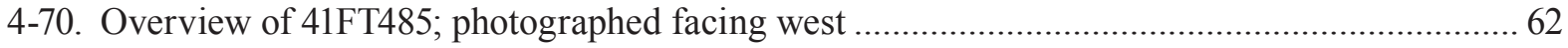

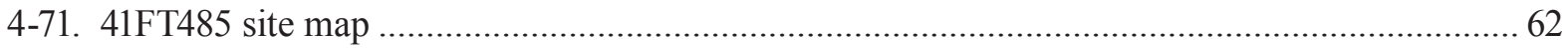

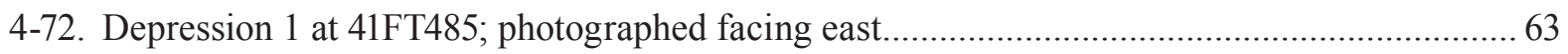

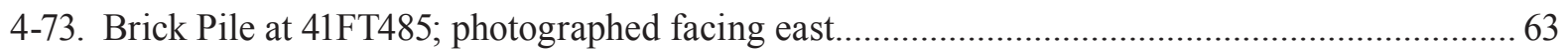

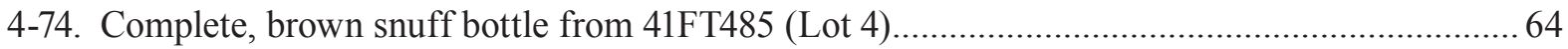

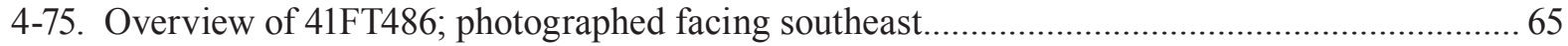

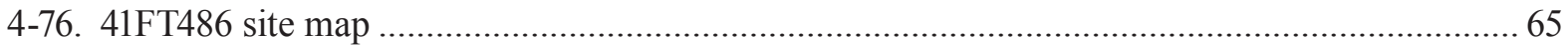

4-77. Linear rock feature, possible pier support, at 41FT486; photographed facing

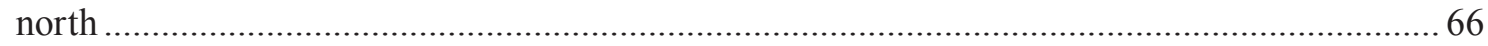

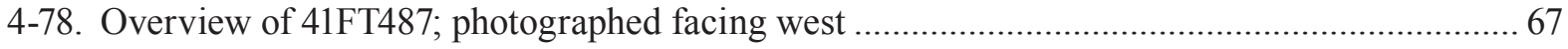

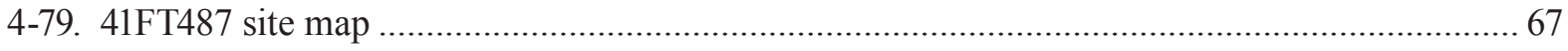

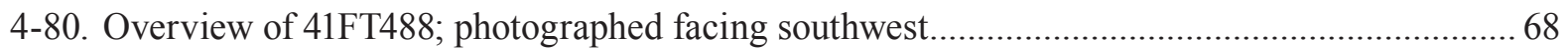

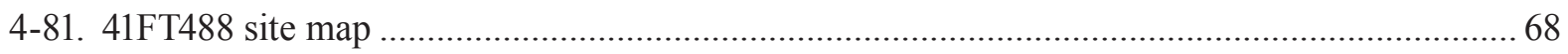

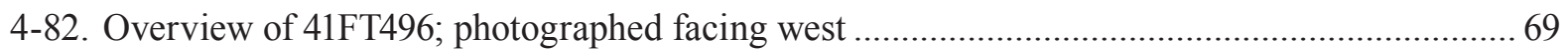

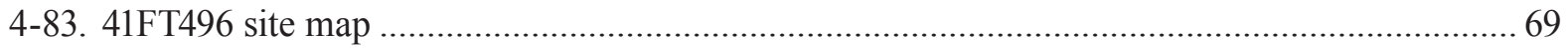

4-84. Untyped, Archaic projectile point recovered from 41FT496 (Lot 1) ...................................... 70

4-85. Overview of 41FT497; photographed facing south ............................................................. 71

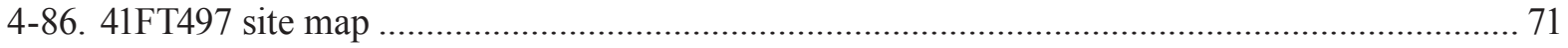

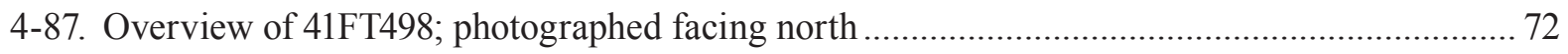

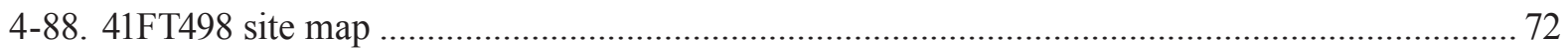

4-89. Overview of 41FT499 feature a historic road cut; photographed facing

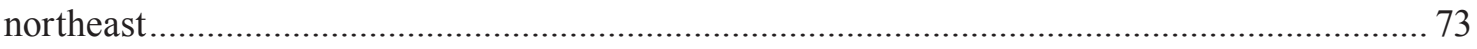

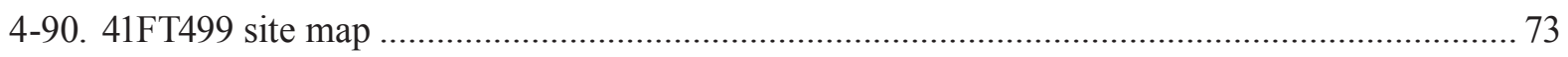

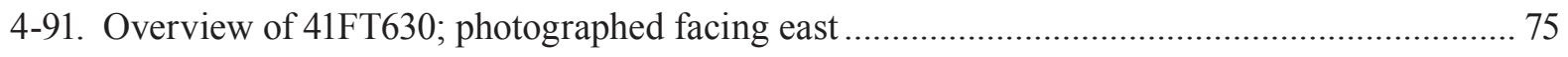

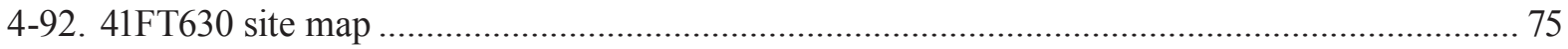




\section{List OF Figures (continued)}

4-93. Headstone at 41FT630... 


\section{List of Tables}

5-1. Sites, their components, and assigned management priority levels....................................... 79 


\section{ACKNOWLEDGMENTS}

Initial fieldwork for this project was carried out by dedicated staff and students of the late Dr. James Corbin of Stephen F. Austin State University. These crews included Don Becker, Stacee Sager, Perry Brown, and Anne Eubanks. The authors would like to acknowledge their important contributions to this project. Additionally, thanks are extended to Ms. Dawn Ramsey, Cultural Resources Coordinator for Region III of Texas Parks and Wildlife Department, who made this project possible and was extremely helpful throughout every phase. We would also like to express our appreciation for Park Superintendent Mike Kleinert and his staff for their assistance with facilitating park access and fieldwork coordination. The fieldwork described in this report was conducted by Gregory LaBudde, Project Archaeologist, and David Yelacic, CAS Archaeologist. Dr. Jon Lohse served as the Principal Investigator for the CAS investigations, and contributed to the fieldwork as well. Maps and illustrations for this publication were prepared by David Yelacic, who also prepared the artifacts, photographs, and documents for curation. Jessica Hurley assembled and edited this report with editing assistance from Brooke Boyer. 



\title{
Chapter 1
}

\section{INTRODUCTION}

\author{
Gregory J. LaBudde
}

This report presents the results of an archaeological survey and site assessment of Fairfield Lake State Park in Freestone County, Texas (Figure 1-1). The initial survey of the 1,460 acre park was conducted during the summer of 1996 by students under the direction of Dr. James E. Corbin of Stephen F. Austin University (SFA). At the request of the Texas Parks and Wildlife Department (TPWD), the Center for Archaeological Studies (CAS) at Texas State University-San Marcos completed the inventory and assessment of the sites in June of 2008 to assist TPWD in the management and stewardship of the park's cultural resources.

During the 1996 survey, conducted under Texas Antiquities Permit No. 1698, a total of 34 sites were recorded or revisited. Shovel tests were excavated on many of the sites, and field maps were drawn of all but two sites. With site documents and records, artifacts, and photographs from the SFA survey, CAS resumed and completed the fieldwork and subsequent report under the same permit number in 2008. In addition to the 34 previously-identified sites, CAS recorded the location and condition of another site, an abandoned historic cemetery within the park. The results of the original survey and subsequent re-evaluations were used to determine each site's eligibility for nomination to the National Register of Historic Places (NRHP) and/or eligibility for designation as a State Archeological Landmark (SAL). In consultation with TPWD personnel, each site was also given an assessment of relative management priority/research potential on a ranked scale of 1 (highest) to 4 (lowest). Specific recommendations are provided for each site in order to address long-term stewardship and management of the sites, and to assist the TPWD in developing a management plan in the event that future developments or undertakings have the potential of impacting cultural resources recorded within the park.

\section{Report Organization}

Including this introductory chapter, the report is divided into a total of five chapters and two appendices. Chapter 2 provides an overview of the environmental setting and the cultural background of the study area, and briefly details previous archaeological investigations. The project's research goals and field and laboratory methods are described in Chapter 3. Chapter 4 provides descriptions of recorded sites and isolated finds, levels and results of work conducted, and offers conclusions and recommendations for each site. A project management summary and overall conclusions and recommendations are presented in Chapter 5.

Appendix A presents the profiles of all positive shovel tests excavated during the 2008 reassessment. Appendix B is a United States Geologic Survey (USGS) Quadrangle map showing the locations of the recorded sites and is 


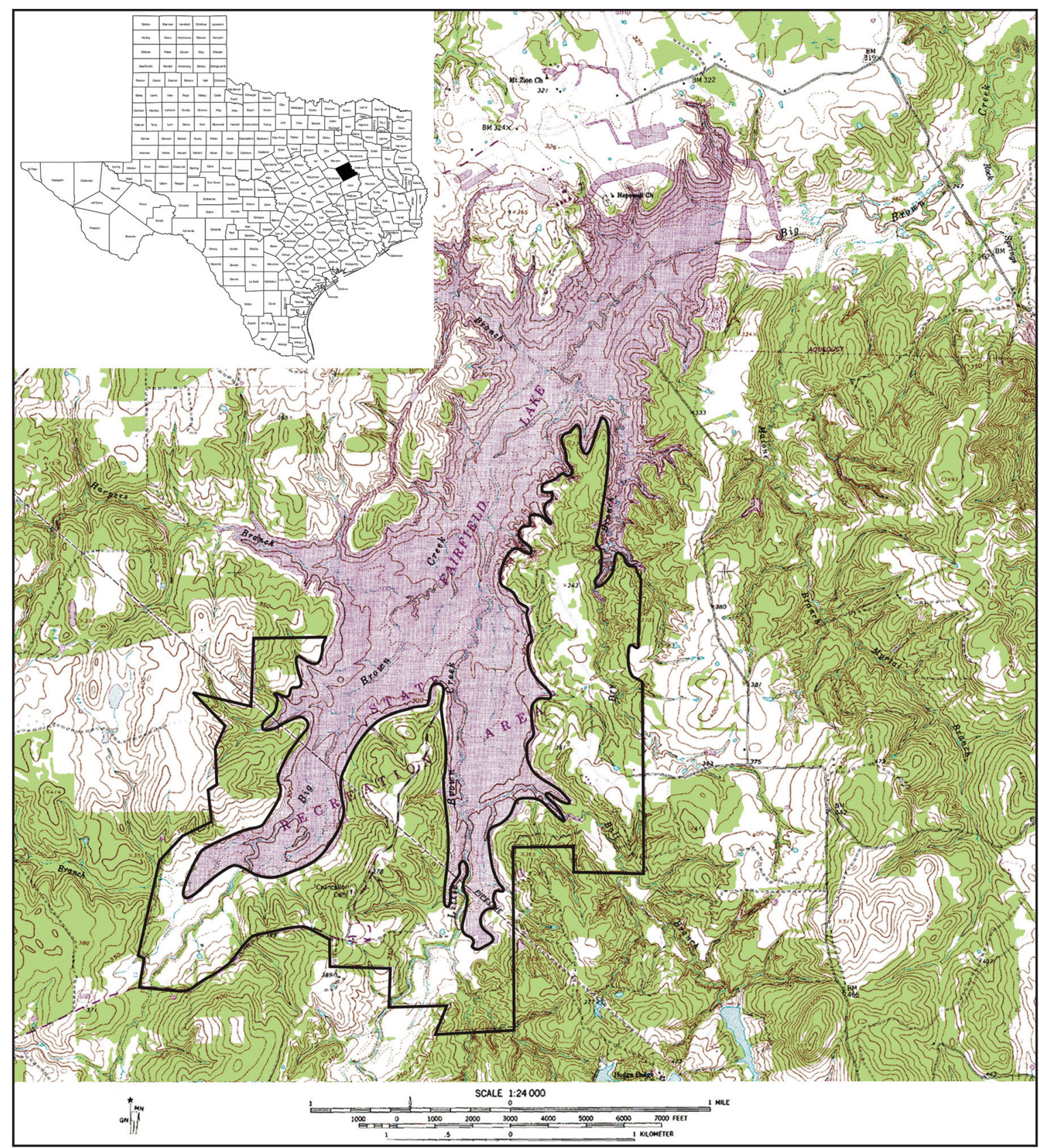

Figure 1-1. Location of Fairfield Lake State Park and survey area of the 1996 project plotted on the Young 7.5' United States Geologic Survey topographic sheet. Inset map shows location of Freestone County in Texas.

included in a pocket envelope at the back of this report. In addition to these project and sitespecific data sets, TexSite forms for all of the sites described in this report were completed or updated as needed. These are available at the Texas Archaeological Research Laboratory, University of Texas, Austin.
Fieldwork was performed by Jon C. Lohse, Principal Investigator, Gregory J. LaBudde, Project Archaeologist, and David M. Yelacic, CAS Archaeologist, during June of 2008. 


\section{Chapter 2}

\section{Project Setting, Cultural Chronology, and Previous Investigations}

David M. Yelacic

\section{Project Area Setting}

Freestone County occupies 892 square miles in northeast Central Texas. The eastern border of the county is demarcated by the Trinity River, and the project area, Fairfield Lake State Park, is located at the confluence of Big Brown Creek and Little Brown Creek, secondary tributaries of the Trinity River .

\section{Post Oak Savannah}

As recently defined by the United States Environmental Protection Agency (USEPA), the United States Geographic Survey (USGS), and other federal and state agencies using a four-tiered hierarchical framework with climate, vegetation, physiography, and other biotic and abiotic phenomena taken into consideration, Fairfield Lake State Park lies entirely within the Level III ecoregion East Central Texas Plains (Griffith et al. 2004) (Figure 2-1). As described by Fields (1995) and supported by Griffith et al. (2004), the East Central Texas Plains, also referred to as the Post Oak Savannah, separates the prairies to the south, north, and west from the Piney Woods to the east. Accordingly, this region is a transitional one consisting of irregular plains and containing stands of pine trees intermixed with hardwoods such as mesquite, oak, and hickory. However, much of the land in this region has been modified for use as pasture and/or farmland.

\section{Fairfield Lake}

In the late-1960s, Dallas Power and Light Company, Texas Electric Service Company, and Texas Power \& Light Company acquired land at the confluence of Big Brown and Little Brown Creeks in order to construct the Big Brown Steam Electric Station (Jasinski 2002). Plans for construction included creating a 2,500-acre, 15 billion gallon lake, which would be used to cool the two generators. Before the Big Brown Steam Electric Station was erected in 1969, Big Brown Creek was dammed. Big Brown Creek, a secondary tributary of the Trinity River, flows from its headwaters northeast for approximately 20 miles to where it empties into Tehuacana Creek, a primary tributary of the Trinity River.

\section{Sediments}

Soils in the project area have been mapped and described by Janak and Griffin (2002) (Figure 2-2). Units include Edge fine sandy loam, 5 to 12 percent slopes (EgE); Nahatche-Hatliff association, frequently flooded (NH); Rader fine sandy loam, 0 to 3 percent slopes $(\mathrm{RaB})$; Silawa fine sandy loam, 5 to 12 percent slopes (SaE); Silstid loamy fine sand, 1 to 5 percent slopes (SsB); Silstid loamy fine sand, 5 to 8 percent slopes (SsD); and Tabor fine sandy loam, 1 to 3 percent slopes $(\mathrm{TaB})$.

Most of these soil associations are found on flat to nearly flat terrain. However, the high sand content leaves topsoil deposits vulnerable to 


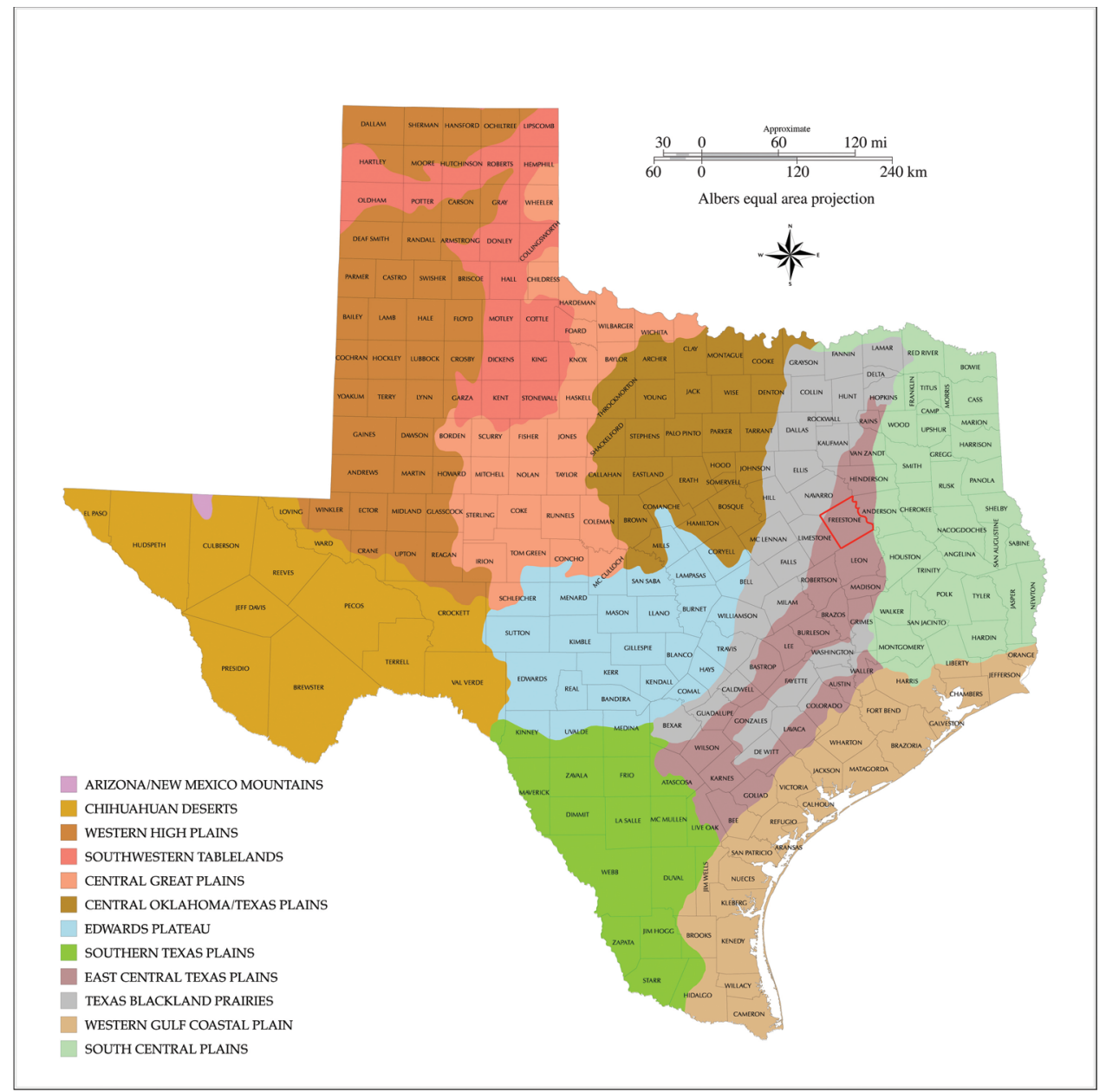

Figure 2-1. Level III Ecoregions map of Texas with Freestone County outlined in red.

runoff and erosion during even light-to-moderate rainfall events. Typical soil depths are often shallow, averaging from as little as about $7.6 \mathrm{~cm}$ in depth $(\mathrm{SaE})$ to approximately $66 \mathrm{~cm}(\mathrm{SsD})$. Subsoils are very often high in clay content, which causes surface water to pool in spite of the permeability of the topsoils. These soils support a limited range of uses, the most notable of which are as pasture and agricultural lands. Salt domes in the southern part of Freestone County (Janak and Griffin 2002:116) are associated with some oil and natural gas production. Additionally, lignite coal deposits are present in the region and have been actively mined for the past several decades and up to the present.

\section{Cultural Chronology for Northeast Central Texas}

Abundant waterways and fertile land have long lured human occupation to northeast Central Texas. The rich human occupation of the region, divided into prehistoric and historic components, is presented in the following paragraphs.

\section{Prehistoric}

Previous investigations have shown that the greater east Central Texas region shares cultural affinities with Central Texas, East Texas, and north Central Texas (Bruseth and Moir 1987); diagnostic artifact types from each of these three regions can be found here. In terms of Prehistoric occupation, the Post Oak Savannah region is best 


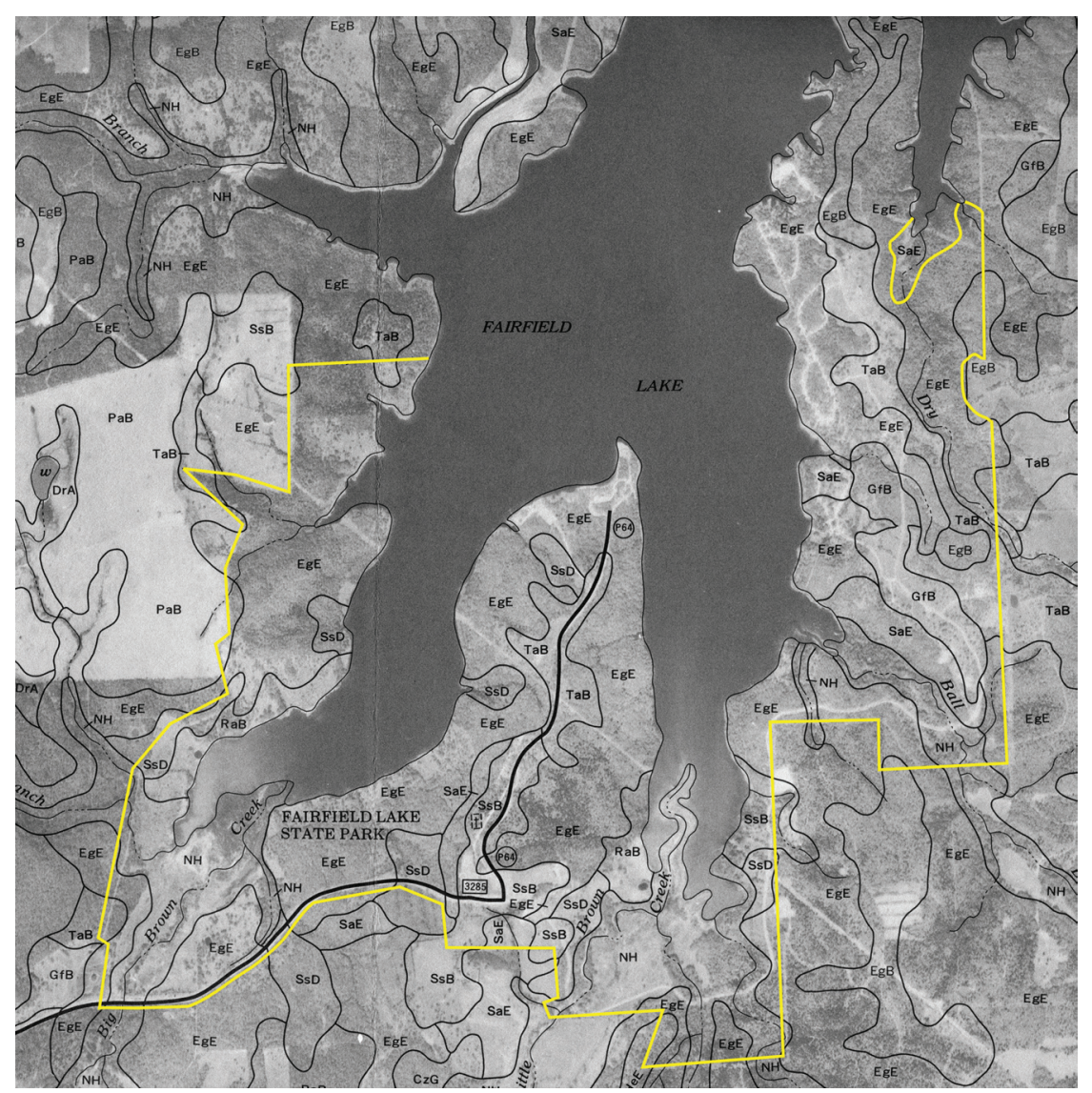

Figure 2-2. Soils found across Fairfield Lake State Park, bounded in yellow (after Janak and Griffin 2002: Plate 19).

known for its Late Archaic and post-Archaic Woodland adaptations (Fields 1995). Although some finds dating to the Paleoindian and Early/ Middle Archaic periods are present, these tend to be scarce. The following cultural chronology of the Prehistoric period is based on the research and interpretations of Dee Ann Story (1965) and Ross C. Fields $(1995,2004)$. A compilation of their data divides the region's prehistoric occupation into four periods whose titles reflect the overlapping of neighboring regions: Paleoindian, Archaic, Woodland, and Late Prehistoric. Supplementing the cultural chronology of northeast Central Texas with comparisons of adjacent cultures is necessary due to the mobile nature of early populations and the dispersive quality of culture. Division within the prehistoric occupation of the region is not meant to indicate discrete temporal units in the region's cultural chronology. Dates provided are approximated in radiocarbon years before present (B.P.).

\section{Paleoindian}

The Paleoindian period, as seen in divisions of Central Texas cultural chronology as predating 8,800 years B.P., is hardly visible in northeast Central Texas' material record. It is represented by scattered, isolated finds of temporally diagnostic dart points including Clovis, Folsom, and Angostura (Story 1965; Meltzer and Bever 1995). Paleoindian discoveries in the region are typically surficial, but they do exist and have been found in subsurface contexts (Fields 1995, 2004; Richner and Bagot 1978). Unfortunately, the subsurface discoveries show evidence of disturbance representing either post-depositional 
erosional movement or later populations' interest in archaeology. The lack of available evidence from the region results in reliance on general trends in Paleoindian populations provided by studies of the earliest occupants in Central and East Texas.

A large distribution of Clovis points across North and Central America suggests a wide dispersal of their makers (Wenke 1990:201). Meltzer and Bever (1995) documented the presence of 406 Clovis points at 128 of the 254 counties in Texas. These early populations in Texas were most-likely small groups of highly mobile, specialized hunter-gatherers. Herds of megafauna and the availability of edible flora are the assumed forces behind the migration of early populations toward the plains of northeast Texas (Perttula 1995, 2004).

\section{Archaic}

Archaeologists' ability to clearly discern differences between traditional Archaic components (i.e. early, middle, and late subperiods) is often hindered by a number of factors. These include the sandy nature of regional sediments, which facilitates the translocation of artifacts beyond original component boundaries and therefore obscures otherwise stratified deposits; the deflated nature of many upland settings; and the generally poor temporal resolution of diagnostic artifact types (Fields 1995). In general, however, the long Archaic occupation (ca. 8,800 to 1,200 years B.P.) of the region is characterized by the gradual emergence of strongly localized cultural traditions; overall reduction in annual and seasonal mobility; an apparent diversification of subsistence resources in response to increasing fluctuations of climate, available moisture, and plant and animal communities; and a corresponding diversification of regional artifact styles and technologies that were designed to exploit this quickly changing environment.

Story (1965) describes Archaic sites as having a high percentage of expedient cutting/scraping tools and rectangular/expanding stemmed, temporally diagnostic dart points. Burned rock features also appear in association with Archaic sites. Sites studied in northeast Central Texas show a concentration of lithic material around burned rock middens and/or hearths, but the environment does not support preservation of floral or faunal remains (Fields 1995, 2004). Evidence suggests that Archaic sites in the region, though slightly and understandably deflated, are in their original context. These sites indicate short-lived, isolated occupations and suggest that their inhabitants were still mobile hunters and gatherers.

\section{Woodland}

Woodland adaptations appear not only in the study area by approximately 1,800 years B.P., but also across the greater Trans-Mississippi south of the southeastern United States (Story 1990). This period is characterized by the introduction of ceramics (in some areas); partial reliance on cultigens, particularly as a complement to seasonally available foraged foods; more prolonged stays at certain locales; social and ritual elaboration; and, later on, the introduction of the bow and arrow. The adoption of ceramic technologies by approximately 1,700 years B.P. implies increasing emphasis on storage of certain foodstuffs. Early vessels are thick and have only simple surface treatments. Temper materials frequently utilized include sand or clay, bone, and grog. Gary points, with sharply triangular blades, contracting stems, and strong shoulders are perhaps the most common point type. Woodland adaptations are more clearly distinguished to the east of the study area, though many of the traits just described are found in Freestone County. 
While postholes are evidence of increasing intensity and longevity of site use, postholes, or possible postholes, and intrusive pits associated with Woodland deposits occur in low numbers. The presence of cultivated botanical remains would suggest that the economy of this time period was transitional, however, the lack of prominence in the organic material record indicates that the populations did not significantly rely on horticulture (Fields 1995:307). The increase in domestic activities represented in the material record from Woodland cultural deposits are evidence of increasing population densities, decreasing mobility, and the multi-seasonal use of sites, which Fields (1995:307) describes as "residential bases" (Perttula 1990:276-277, cited in Fields 1995).

\section{Late Prehistoric}

The Late Prehistoric period occupies the time from ca. 1200 years B.P. to ca. 500 years B.P. (Fields 1995, 2004; Story 1965). The introduction of the bow-and-arrow, the intensification of food production, and the elaboration of architectural forms and ceramic technologies define the Late Prehistoric period. It is notable that despite the prominence of arrow points, dart points continue to be recovered from this period's cultural deposits, suggesting that atlatl and bow-and-arrow technologies overlap (Fields 1995:310). Structures of this time period are more common. Postholes indicate sub-rectangular to rectangular shaped structures, and at some sites, postholes were overlapping and indicate multiple construction events (Fields 1995, 2004). Intrusive pits, hearths, trash middens, and burials associated with remnants of structures are evidence of increased domestic activity and the spatial distribution of intrasite activities (Fields 1995). Botanical remains from cultivated species, as well as foraged species, are present in association with Late Prehistoric cultural deposits and are evidence of an increased reliance on horticulture
(Fields 1995, 2004). However, the botanical evidence still indicates that these populations relied mainly on wild plant food. Despite the more dominant structures, spatial patterning of activities, and evidence of increased horticulture practices, there is no evidence supporting yearround, sedentary occupations of this region's populations during the Late Prehistoric period (Fields 1995). Ceramic technology of this period continues to advance and plays a more prominent role in the culture. Although sherds recovered at many sites are too small to indicate any specific type of vessel, a low percentage does reveal some important stylistic innovations. Decoration including neck-banding, incision, engraving, punctation, and pinching show evidence of trade with and/or cultural influence from Caddo neighbors to the north and east (Fields 1995:315). Contemporary Caddoan groups in the Piney Woods and Red River regions are considered to have more complex social systems than the populations in this region (Fields 1995; Perttula 1995).

\section{Historic: A Brief History of Freestone County}

The history of Freestone County, and specifically the land that now constitutes Fairfield Lake State Park, is provided by a report written by Laurie E. Jasinski (2002) on behalf of Texas Parks and Wildlife Department (TPWD).

European exploration of the county began as early as 1542 . According to a 1939 study by the United States De Soto Commission, Luis de Moscoso Alvarado led an expedition that may have traversed the county. More definitively, the 1690s was a decade in which trails including the Upper Presidio Road, which skirted the southern border of present day Freestone County, were improved upon and provided a route for Spanish explorers, militia, government officials, and 
clergy to travel on between east and south Texas. In the eighteenth century, Spanish colonists and French explorers and entrepreneurs, who were navigating east Texas' plentiful waterways, took notice of Native American groups migrating into the region. Nomadic groups followed bison into the area while groups of semi-sedentary people found fertile land and abundant trade with other indigenous groups and Europeans.

During the transition from the eighteenth to the nineteenth century, American explorers from the colonies on the Atlantic coast began to venture into the region, much to the dismay of the Spaniards. One notable figure, Phillip Nolan, traveled through Louisiana and allegedly produced the first map of Texas; neither he nor the map survived this final journey in 1801 as they were intercepted by Spanish soldiers. In 1821, Mexico, which then included the present state of Texas, gained independence from Spain. Unlike Spain's miserly views on settlement in the region, the newly formed Mexican government allowed individual states to regulate colonization on their own accord. The State Colonization Law of March 24, 1825 opened the door for the settlement of Texas. Subsequently, David G. Burnet of Ohio secured a contract with the Mexican government in 1826 to bring 300 families of settlers into Texas. However, financial misfortunes kept Burnet from executing his plan, and the rights to the land were sold to the Galveston Bay and Texas Land Company in 1830. Also in 1830, a suspicious Mexican government passed the Law of April 6th to put an end to the American colonization and influence of the region. Not long after American settlement in Texas was stemmed, the Mexican government awarded two statesmen with significant land grants. Juan Nepomuceno Acosta, priest and one-time President of the Senate of the National Congress, and Mariano Rivas Palacios, who would later become the governor of the State of Mexico, received adjacent land grants of 48,712.4 acres each. In 1832 , before the land was officially surveyed and awarded, Mariano Rivas Palacios turned over his land grant rights to his godson, Enrique Antonio Mexia. The Mexia family, at an unknown date, either claimed or purchased the Acosta grant and consequently controlled a sizeable tract of land. All the while, these bureaucratic exchanges of land rights did not affect the occupying groups of Native Americans.

Independence from Mexico gained by the Republic of Texas in 1836 added more to the confusion over land ownership. In the middle of the nineteenth century, the area that would later become Freestone County was largely unsettled. Surveyors plotted new tracts with no regard to previous titles, such as the Mexia family's, and the Republic of Texas issued headrights to citizens and immigrants. Benjamin Edwards of North Carolina was an early settler of Freestone County, and in 1847, he received a headright that included land adjacent to Big Brown Creek. It is possible that his property extended to the present Post Oak Campsites in the northeast corner of Fairfield Lake State Park. Headright parcels adjacent to Edward's were surveyed and awarded throughout the 1840s and 1850s, but rights to the grants were exchanged several times. In some cases, headrights were forfeited and the title defaulted to the Mexia family. Shortly after the annexation of Texas into the United States in 1845 , migration to the region increased with a majority of the population coming from southern states. Many families who settled the area near Big Brown Creek came from Wilcox County, Alabama. In the early days of Fairfield, which was officially established in 1851 as the county seat of Freestone, farms fueled the economy and the Trinity River provided transportation to market places. Many of the pioneer families brought their slaves and established farms or plantations to grow cotton, corn, and tobacco. 
In 1851, Benjamin Edwards sold his headright to Dr. William D. Strain. The Edwards family moved to what is presently the southwestern portion of the park, and the Strain family set up a cotton plantation. Also settled in the southern end of the present park was the Chancellor Family. In the 1850s, the Chancellors and their slaves moved to Freestone County from Wilcox County, Alabama. On the Chancellor's parcel, a one-room church and school was built. An adjacent cemetery, the Chancellor Union Cemetery, served as the final resting place for members of the Chancellor family, other related families, and their slaves. Another prominent family along Big Brown Creek was the Oliver Family. William W. Oliver, a wealthy merchant and landowner in Limestone County, purchased from the Mexia family an 1,100-acre tract that the Olivers had occupied for half of the previous decade. One of W. W. Oliver's daughters married into the Stroud family, one of the largest slave holding families in Freestone County. Slaves were figuratively invaluable to the farming community of Freestone County. In the years before the Civil War, Freestone County was one of the leading slave and cotton counties in the state of Texas, and its economy and population prospered as a result.

In late 1860, on the verge of the Civil War, Freestone County voted 585-to-3 in favor of seceding from the union. Many prominent members of the community served in the war, but of the 1,000 men that left, only 300 survived. During the war, plantations continued to thrive, and Freestone County's prosperity, owed in large part to free labor, went uninterrupted. The end of the Civil War and consequent Emancipation Proclamation marked the beginning of difficult times for the economy of the county. White and black families alike struggled with the economic and social changes. During Reconstruction, many freed slaves continued to work land belonging to their former masters as sharecroppers. Impoverished white families also found work as sharecroppers and tenant farmers, and this agricultural practice continued into the 1960s in Freestone County. In the 1870 s and 1880s, although railroad lines just grazed the county's borders to the north and south, the proximity of the railways to Fairfield allowed the population and the number of farms to increase significantly.

Land adjacent to Big Brown Creek, which would later become Fairfield Lake State Park, was maintained by many of the families that had acquired or purchased the land prior to the Civil War, but a few tracts were exchanged often between residents of the county. The east side of the present park was consistently owned by the Oliver and Stroud families to the turn of the twentieth century, and the Chancellor family maintained the southern portion of the present park into the 1900s. The Hill family purchased the Oliver/Stroud tract in the early 1890s, and soon became a prominent family in Fairfield. The Huckaby, McDonald, and Miller families were also notable newcomers to the land adjacent to Big Brown Creek. On the Chancellor tract, the one-room building that was both a church and a school continued to serve the growing farming community. Cook's Ferry Road and a number of back roads connected the Big Brown Creek area farming families with each other, Fairfield, and the Trinity River. Natural gas and oil discoveries in the region during the early twentieth century introduced new prosperity to the economy. While land leasing and prospecting grew rapidly, farming continued to lead the area's economy. However, in the 1920s, farming in Freestone County went into decline in response to the Great Depression and the boll weevil infestation. In order to compensate for the failing agricultural market, some rural residents turned to bootlegging liquor. Prohibition did not stop Freestone County from becoming nationally recognized for its 
quality and quantity of whiskey. Despite attempts by local authorities, this illegal industry persisted for several decades.

While the Depression forced some of the Big Brown Creek area families to part with their land and move on, it provided the opportunity for other families, the Hill family specifically, to increase their holdings. In the 1930s and 1940s, the Hills bought large tracts from the Huckaby and McDonald families. When land surrounding Big Brown Creek was bought out by energy companies in the 1960s, the Hills owned a majority of the property that would become the park. In the 1930s, the one-room church and school on the Chancellor tract was struck by lightning and burned down. It was never rebuilt, and the Chancellors sold their property to the Bonner family in 1947. The Bonners were an old and prominent family in the county, at one time operating one of the largest plantations in the county and contributing significantly to the development of the Masonic Lodge and Fairfield Female College.

In the 1950s, what was left of tenant farms faded into pasture and range for ranching. The overgrown fields and old roads also provided recreational areas for descendents of the families who had settled the region.

\section{Previous Archaeological Investigations}

Freestone County's proximity to the Trinity River and aforementioned ecotone provide living conditions that human populations have found suitable since the early Holocene. The county has rich subsurface mineral resources and an abundance of waterways, and these natural resources have long been exploited. In recent history, developmental protocols requiring cultural resource investigations prior to construction have added significantly to the archaeological record of the area. Three regionally relevant, large scale investigations, including the Jewett Mine Project, Tennessee Colony III project, and Richland/Chambers project, will be discussed briefly. The current project area, entirely within Fairfield Lake State Park boundaries, encompasses approximately 35 prehistoric and historic sites. Four of these, 41FT279, 41FT280, 41FT408, and 41FT409, all historic sites, were discovered during investigations prior to SFA's 1996 project. While previous investigations of 41FT279, 41FT280, 41FT408, and 41FT409 are described below, because SFA's mid-1990s cultural resources inventory of the park is the focus of the current project, evaluations and reevaluations of recorded sites will be discussed as results.

\section{Jewett Mine Project}

Jewett Mine is a 35,000-acre mining complex which supplies two Limestone Electric Generating Stations in northeast Central Texas with approximately 7.5 million tons of lignite per year (Westmoreland Coal Company 2008). This large operation required that a number of surveys, testing projects, and mitigations be performed by several private firms beginning in 1979. Investigations resulted in the discovery of 418 total sites (Fields et al. 1995). Of these 418 sites, 239 contained prehistoric components and 179 contained historic components. A total of 79 sites were tested and 17 sites were mitigated (Fields et al. 1995).

This extensive archaeological investigation, reported by Fields et al. (1995) of Prewitt and Associates Inc., supplied basic knowledge about the prehistory of the region, which was previously not well understood. However, gaps in the project area's cultural chronology do exist. Occupation predating the Late Archaic period is not as well represented as occupations 
associated with the Late Archaic, Woodland, and Late Prehistoric periods; therefore, little is known about the Paleoindian and Early to Middle Archaic inhabitants of the region. Evidence of the region's inhabitants during the early Historic period is not present in the material assemblage either. Another aspect of the region's prehistoric culture that is missing from the material record is evidence of subsistence practices before the Late Prehistoric. Unfortunately, the environment does not support the preservation of organic material.

\section{Tennessee Colony III and Richland/ Chambers Projects}

In the mid- to late-1970s, archaeological investigations were conducted prior to the construction of a dam that would create a large reservoir in the northern portion of Freestone County. Initially, the reservoir was going to be called Tennessee Colony Lake. Southern Methodist University's (SMU) Archaeology Research Program, on behalf of the Army Corps of Engineers, performed three surveys in the area that would potentially be affected by Tennessee Colony Lake; 311 prehistoric and historic sites were discovered (Richner 1982). Many of these sites, at the time, contained cultural material worth mitigating. Partly as a result of these finds, plans for Tennessee Colony Lake were abandoned for the Richland/Chambers reservoir. The Richland/Chambers Reservoir was a fraction of Tennessee Colony Lake's size. The project area was also investigated by SMU's Archaeology Research Program. During investigations, a total of 53 prehistoric and historic sites were mitigated. Results of mitigations from prehistoric sites revealed trends similar to those of the Jewett Mine project: evidence of Paleoindian and Early to Middle Archaic occupations was minimal and evidence of economic/subsistence practices before the Late Prehistoric period was not preserved (Bruseth and Moir 1987). Extensive research of historic records and historic site mitigations were also performed during investigations for the Richland/Chambers Reservoir.

\section{Additional Investigations}

The projects described above contributed tremendously to the understanding of the region's cultural chronology. In addition, other intensive investigations of Fairfield Lake State Park land were conducted prior to various lignite mining projects. The following four sites are included in the current project but were discovered prior to 1996. They have all been evaluated on numerous occasions under different auspices, and the following paragraphs are short histories of their archaeological records. Information regarding these sites was obtained from the Texas Historical Commission's Texas Archeological Site Atlas Database Forms (TASDF).

\section{$41 F T 279$}

Site 41FT279, "Springfield Camp Ground Site" and later "the Hill House Site," is a historic site. It was originally discovered by George Kegley in 1972, shortly after the land was acquired by the state and before the park was opened to the public. In 1983 and 1991, the site was re-evaluated by the TPWD, first by Ron Ralph of the Master Planning Branch and later by Dan Crouch of the Historic and Restoration Branch. Dan Crouch's 1991 re-evaluation of 41FT279 is the earliest available on the TASDF. In 1996, SFA included a re-evaluation of 41FT279 in their scope of work. The site is described and discussed further Chapter 4.

\section{$41 F T 280$}

Similar to 41FT279, 41FT280 is a historic site discovered by George Kegley in 1972. The site was re-evaluated by Ron Ralph of the Master Planning Branch in 1983 and again in 1991 by Dan Crouch of the Historic and Restoration Branch of the TPWD. 41FT280 will also be discussed in 
detail as part of both SFA's 1996 project and the current project in Chapter 4.

\section{$41 F T 408$ and $41 F T 409$}

The discovery of sites 41FT408 and 41FT409 is somewhat mysterious. It is possible that George Kegley and Art Black of TPWD discovered them prior to 1980 , but no date is disclosed. In 1980, Dr. James E. Corbin of SFA, working under the auspices of Prewitt and Associates, Inc., performed a survey prior to the installation of a buried cable. Sterile shovel tests along the proposed route suggested that the sites would not be impacted by development. TPWD surveys in 1993 and 1997, performed by Ron Ralph, re-evaluated these sites, as, on both occasions, they had the potential to be impacted by a park trail extension. On recommendation, the park trail extensions avoided 41FT408 and 41FT409. Evaluations of these sites by SFA in 1996 and CAS in 2008 will be discussed in Chapter 4. 


\title{
Chapter 3
}

\section{Research Goals and Methods}

\author{
Gregory J. LaBudde
}

\section{Project Goals}

This project documents the efforts of CAS to assess and report the findings of an intensive archaeological survey of Fairfield Lake State Park conducted during the summer of 1996 by Stephen F. Austin (SFA) students under the direction of Dr. James E. Corbin. CAS's efforts focused primarily on three distinct activities: (1) compilation of the forms, notes, documents, and other records generated during the 1996 survey; (2) verification of the locations, descriptions, and present conditions of the 34 recorded sites, and documentation of one newly recorded site; and (3) preparation of the records and artifacts generated during the initial survey and subsequent reassessment for long-term curation.

Archaeological sites were evaluated with reference to the criteria presented in Sections 26.7 and 26.8 of the Rules of Practice and Procedure in the Antiquities Code of Texas, as well as the criteria set forth in the National Register Criteria for Evaluation (36 CFR Part 60). In consultation with Texas Parks and Wildlife (TPWD) personnel, each site was also given an assessment of relative management priority on a ranked scale of 1 (highest) to 4 (lowest). Specific management recommendations, sometimes including the need for further research not covered under the scope of this report, are provided in Chapter 4.

\section{Management Level}

Thirty-five sites were documented inside the park and were graded for management priority. The following factors weighed heavily in the decision of management priority level: the integrity and depth of the sediments if the site was beneath the surface; the amount, distribution, and degree of disturbance of artifacts and features; the amount of modern disturbances; and the geographic and topographic location of the site. A full list of sites, their components, and assigned management priority levels can be viewed in Chapter 5, Table 5-1.

Keeping the aforementioned considerations in mind, Level 1 was reserved for sites which appeared to be intact, whose integrity was superb, and whose research potential seemed great. Only a small number of sites received this classification. Level 2 was assigned to sites which appeared to be intact and had maintained integrity, but whose research potential was moderate. Level 3 was assigned to sites with low or poor integrity and research potential. Most sites were assigned a priority of Level 2 or Level 3. Level 4 was reserved for sites which had been all but destroyed by modern development, were seriously impacted by erosion and deflated landforms, or were entirely deflated. 


\section{Archaeological Site Evaluation Criteria}

Although there are no immediate plans to develop the archaeological sites hitherto identified within the park, guidelines set forth by federal and state agencies for eligibility on the National Register of Historic Places (NRHP) and as State Archaeological Landmarks (SALs) will be used as a rubric for determining site significance. Archaeological sites identified as significant cultural resources may be protected by federal law, primarily by the National Historic Preservation Act (NHPA) of 1966, which is invoked when federal funds are utilized or when federal permitting is required for a proposed undertaking. The NHPA created the NRHP, and states that the Advisory Council for Historic Preservation (ACHP) must be afforded the opportunity to comment when any cultural resources potentially eligible for inclusion in the NRHP are present in an area affected by federal agency actions, or by any actions funded or permitted by federal agencies. The federal regulatory process is described in detail in the ACHP regulation 36 CFR 800.

Protection of cultural resources under federal law is tied to eligibility for the NRHP, which depends on site significance as defined by National Park Service (NPS) rule 36 CFR Part 60. Four criteria are applied to archaeological sites in determining their significance. These address properties that are:

(a) associated with events that have made a significant contribution to the broad patterns of our history; or

(b) that are associated with the lives of persons significant in our past; or

(c) that embody the distinctive characteristics of a type, period, or method of construction, or that represent the work of a master, or that possess high artistic values, or that represent a significant and distinguishable entity whose components may lack individual distinction; or

(d) that have yielded, or may be likely to yield, information important in prehistory or history.

Cultural resources located on land owned or controlled by the State of Texas or its political subdivisions are protected by the Texas Antiquities Code (Texas Natural Resources Code, Title 9, Chapter 191), which identifies significant sites as SALs. Should any historic or prehistoric sites located on land that is designated for impact during development be determined eligible for formal designation of landmark status under the Texas Antiquities Code, some measure of protection or mitigation of impact may be necessary. The formal designation of SALs and their administration is the responsibility of the Texas Historical Commission (THC).

The Texas Antiquities Code generally requires that a complete archaeological survey be undertaken in conjunction with projects that fall under its purview, particularly in previously unsurveyed areas and in regions where cultural resources are expected. Any resources determined to be significant must then be avoided, protected, or their destruction mitigated by approved data recovery programs.

Worthiness for designation as a SAL is defined in the Texas Antiquities Code, which states:

Archeological sites may be considered significant and be recognized or designated as State Archeological Landmarks, provided that at least one of the following conditions is met (Rules and Practice, Chapter 41:10): 
The archeological site is situated on land owned or controlled by the State of Texas or one of its political subdivisions; [and then]

(a) preservation of materials must be sufficient to allow application of standard archeological techniques to advantage; and/ or

(b) the majority of artifacts are in place so that a significant portion of the site's original characteristics can be defined through investigation; and/or

(c) the site has the potential to contribute to cumulative cultural history by the addition of new information; and/or

(d) the site offers evidence of unique or rare attributes; and/or

(e) the site offers a unique or rare opportunity to test techniques, theory, or method of preservation, thereby contributing to scientific knowledge.

\section{Field Methods}

\section{Surface and Subsurface Investigations}

Aftercompilingand reviewing theinformation collected during the 1996 student-conducted survey, CAS archaeologists returned to the park in June of 2008. No attempt was made to fully document each of the 34 individual sites recorded during the initial survey. Instead, emphasis was placed on relocating and reassessing each site.

Site assessments began with thorough inspections of ground surfaces for features and artifacts. Limited shovel tests were excavated to establish or verify sites boundaries as needed. At least one shovel test was excavated on each prehistoric site to record the composition and depth of the sediments, and when possible, the vertical extent of artifact deposition. Shovel tests measured $30 \mathrm{~cm}$ in diameter, and were excavated in 20-cm levels to sterile subsoil or a depth of approximately $100 \mathrm{~cm}$ below surface $(\mathrm{cmbs})$. Sediments were screened through 1/4-inch wire mesh, and all shovel test pits were backfilled after completion.

\section{Field Documentation and Artifact Collection}

All but three of the sites had been mapped in varying degrees of detail and accuracy by the SFA crew. Sketches of unmapped sites were generated using tape and a compass. SFA site maps, when available, were digitized and corrected and/ or amended as needed. Amendments include the locations of previously unrecorded surface features and changes in vegetation (i.e., tree lines). The locations of new shovel tests and datum tags were also added to the SFA site maps. To facilitate the relocation of the sites, datum tags were affixed to healthy trees four to six feet above ground. With few exceptions, a single datum tag was placed near the center of each site. Two datum tags were used on one especially large site, and conditions at some sites required that the datum tags be placed along site boundaries. The locations of datum tags were recorded with a Garmin map76 GPS (Global Positioning System) receiver.

Digital photography was used to document sites. A minimum of two general overview shots of each site was taken to illustrate the site setting. When appropriate, additional photographs were taken of surface features, datum tag locations, and artifacts recovered but not collected from shovel tests. Information about each photograph was recorded on a photographic log.

In addition to the 34 sites that the SFA crew recorded or revisited, CAS archaeologists examined an abandoned cemetery within the boundaries of the park. Although the cemetery was not marked with a datum tag, its UTM 
coordinates were recorded. After careful inspection of the ground surface, a map was drawn of the area depicting the location of a single headstone and the outlines of several possible unmarked, sunken graves. The cemetery was documented with photographs, but no subsurface testing was conducted. A full description of the cemetery is provided at the end of Chapter 4 .

Since the SFA crew collected artifacts from many of the sites they recorded or revisited, artifacts were collected during the 2008 reassessment only under certain circumstances. Collection was limited to artifacts found on the surface that either (1) could be used to date a site with a reasonable level of accuracy, or (2) were susceptible to collection by park visitors. Special attention was paid to glass bottles and bottle fragments displaying maker's marks. With one exception, artifacts recovered from shovel tests during the reassessment were returned to their respective pits prior to backfilling.

\section{Laboratory Methods}

\section{Laboratory Methods and Curation}

Artifacts recovered during the initial survey of the park had been washed, labeled, and preliminarily inventoried by SFA staff. Unfortunately, some information regarding artifact provenience was apparently lost between the initial survey and subsequent reassessment. Cultural materials collected during the reassessment were transported to the CAS lab in San Marcos for processing and inventory. Artifacts collected in 2008 were processed in accordance with the TPWD Archeology Lab Manual. Artifacts collected in 1996 and 2008 were prepared for storage in accordance with federal regulation 36CFR 79, TPWD Archeology Lab Manual, and the Texas Archeological Research Laboratory (TARL) guidelines. All artifacts from the park were placed in 4 mil, resealing bags made of virgin polyethylene. Acid-free labels with provenience information were placed in all artifact bags. Artifacts collected in 2008 were individually labeled with acryloid B-72 and archival ink. All artifacts were separated by site and material, and stored in acid-free boxes.

All field records, artifacts, maps, photographs (digital and hardcopy), and photographic logs were submitted to TPWD along with copies of this final report on acid-free paper. Texas Archeological Site Data Forms (TASDF) were completed for all archaeological sites described in this report. These forms were submitted in TexSite database and paper formats to TPWD and TARL.

\section{Artifact Categories and Analysis}

Artifacts recovered from the park during the 1996 survey and 2008 reassessment were categorized following the TPWD Archeology Lab Manual, but with some minor modifications. Lithic artifacts were categorized as formal tools, bifaces, cores, debitage, fire-cracked rock, cobbles, and lithic-other. Formal tools included projectile points, nutting stones (pitted stones), and grinding stones (metates). Bifaces are defined as tools that exhibit retouch scars on both sides, but lack the hafting modifications that characterize projectile points. Cores are defined as cobbles that exhibit faceted platforms from which flakes have been deliberately removed. Debitage, the by-product of stone tool production, was categorized as exterior flakes, interior flakes, and possible flakes. Exterior (or cortical) flakes are debitage resulting from early stages of tool production. Interior flakes lack cortex and are usually produced during the later stages of tool production. Possible flakes include several pieces of silicified wood collected in 1996 that show no unequivocal indications of cultural modification. Burned quartzite and sandstone rocks were categorized as fire-cracked rock. Rounded, 
unmodified stones collected during the 1996 survey were categorized as cobbles. The category lithic-other was reserved for specimens collected during the 1996 survey that exhibit either minor or questionable modifications.

The historic artifacts were sorted into five broad material types: ceramic, glass, metal, plastic, and structural debris (e.g., brick, mortar, and plaster). Although most of the categories within these material types are self-explanatory, glass artifacts were categorized by inferred form. More specifically, the category bottle glass was reserved for sherds that could be confidently identified as bottle fragments. Vessel glass was used for sherds exhibiting curvature consistent with either bottles or tableware. Vessel glass was also used for specimens that could be clearly identified as jar fragments. The category miscellaneous glass was reserved for a single specimen of unknown origin and function.

\section{Estimated Dates of Occupation}

The estimated dates of occupation of the sites described in this report were determined primarily from the known date ranges of certain types of artifacts. Temporal associations for prehistoric artifacts diagnostic of specific periods follow Turner and Hester (1999). Historic occupations were estimated using ceramics, glass, nails, and to a lesser degree, bricks. The ceramics collected and observed during the survey and reassessment of the park include various earthenwares, stonewares, and porcelain. The earthenwares, which consist primarily of whiteware and ironstone, are commonly found on late nineteenth to early twentieth century sites. British whiteware was commonly imported to the U.S. from 1820 to 1880. After 1880, American potters began producing large quantities of refined earthenwares for the American market (Ketchum 2000). Developed in 1845, ironstone was an inexpensive and durable form of whiteware commonly used as tableware through the first quarter of the twentieth century (Ketchum 2000). White earthenwares are still produced today, and dating undecorated sherds can be difficult (Miller 1993). Special attention was paid to specimens of refined earthenware exhibiting maker's marks. The dates for specimens with identifiable marks were taken from Barber (2001).

Stoneware is a utilitarian ware with a long history in Europe and America. Increasingly available in North America during the nineteenth century, small stoneware potters continued to manufacture utilitarian vessels for local consumption until the mid-twentieth century (Greer 2005). Stonewares identified within the park exhibit three glaze types: salt, Bristol, and Albany. Salt glazes exhibit a distinctive orange peel texture. First developed in Germany during the fifteenth century, salt glazes were largely replaced with other glazes in the U.S. near the turn of the twentieth century (Greer 2005:180181). Albany glazes are characterized by a smooth brown appearance. First developed during the first quarter of the nineteenth century, Albanylike slip glazes became increasingly popular during the late nineteenth century, and were employed by American stoneware potters until the first quarter of the twentieth century (Greer 2005:194). Bristol glaze is characterized by its smooth white appearance. Developed during the late nineteenth century, Bristol glaze became very popular during the Victorian era and continued to be used on American stonewares through the mid-twentieth century (Greer 2005:211-212).

Two types of glass were especially useful in dating the sites described in this report. Dark olive, sometimes called "black," wine bottle glass has some diagnostic utility. Mass produced in America between the 1840s and 1880s, socalled black glass was uncommon after 1880 (Lindsey 2008). Solarized glass was also useful. 
The amethyst color of solarized glass is the result of ultraviolet exposure of manganese, which was used by manufacturers to neutralize the natural hues of unaltered glass between 1880 and 1915 (Munsey 1970:55). Another glass with some diagnostic utility is opaque white glass, commonly called milk glass, which was used in a variety of bottles and jars from the 1870 s to the mid-twentieth century (Lindsey 2008). As with earthenwares, special attention was paid to bottles exhibiting maker's marks, the dates of which were taken from Toulouse (1971).

Structural debris, specifically nails and brick, can sometimes be used to date sites, although with less resolution than many other types of historic artifacts. Commonly found on historic sites, nails take three basic forms: wrought, cut, and wire. Hand wrought nails, first made in Europe during the Middle Ages and used in the U.S. into the nineteenth century (Hume 1969:252), are rare in
Texas. Cut nails, sometimes referred to as square nails, were first produced around 1790 (Hume 1969:253). Although still in use today, cut nails were largely replaced with wire nails during the last quarter of the nineteenth century (Hume 1969:254). In sum, structural debris containing cut nails can generally be dated to a period between 1790 and 1900 .

In this report, bricks are categorized as either low-fired or machine-made. Early Texas settlers commonly made and used hand-made, low-fired bricks manufactured of local clays from the 1820 s through the first quarter of the twentieth century, when brick-making became largely industrialized (Steinbomer 1982:33-70). The hand-made brick industry was defunct by 1955 (Cook 1998:137). As with some bottles and ceramics, machinemade bricks sometimes display maker's marks which can be used to identify the location and date of manufacture. 


\title{
Chapter 4
}

\section{Site Descriptions and Recommendations}

\author{
Gregory J. LaBudde and David M. Yelacic
}

\section{FT279}

Named after the Hill family who owned this land prior to the construction of Fairfield Lake, the "Hill House" site is in the northeast portion of the park and occupies the flat top of a westerlytrending ridge. The horizontal extent of the site, as delineated partially by park development and partially by CAS 2008 shovel tests, measures approximately 50-m (N/S)-x-65-m (E/W) (Figure 4-1). Except for in a small copse of trees at the center of the site, the Silawa fine sandy loam $(\mathrm{SaE})$ is shallow and eroded.

41FT279 was discovered in 1972 by Texas Parks and Wildlife Department (TPWD) archaeologist, George Kegley. The site was revisited in 1983 by TPWD archaeologist, Ron Ralph, and againin 1992 by TPWD historian, Dan Crouch. Currently, what remains of the site is surrounded by developments, including six Springfield Campsites, a clearing that was recently used as a playground, an amphitheater, and restroom facilities (Figure 4-2). There is also a buried cable cutting through the northeastern portion of 41FT279. Just north of the amphitheater and restroom facilities, there is a brick-lined well that measures approximately one meter in diameter and is approximately $10-\mathrm{m}$ deep. It is presumably associated with the Hill homestead.

\section{Levels of Work and Results}

When the Stephen F. Austin (SFA) survey crew revisited 41FT279 in 1996, they collected a small sample of historic artifacts from the surface, including sandy mortar, a ceramic marble, a cut nail, and a single sherd of decorated earthenware. In 2008, CAS archaeologists excavated a total of six shovel tests to delineate the site's southern and eastern boundaries and also to investigate subsurface deposits. Four shovel tests contained cultural material and complete descriptions can be found in Appendix A. Shovel Test (ST) 1, near the center of the small copse of trees, contained:

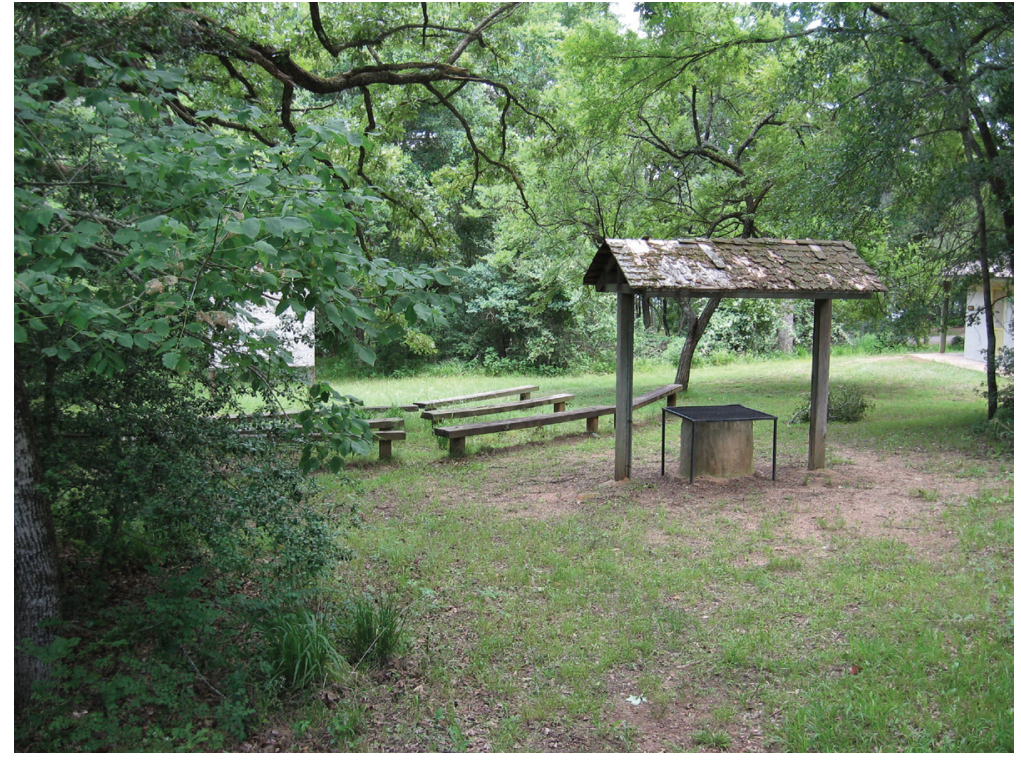

Figure 4-1. Southern boundary of site showing the amphitheater, well, and restroom facilities; photographed facing south. 
five wire nails, a cut nail, a staple, a lead finial, a piece of burned bone, two undecorated earthenware sherds, a brown vessel glass sherd, seven clear vessel glass sherds, and four flat glass sherds (Figure 4-3). At the interface between the sediment which contained the cultural material and the sterile subsoil, there was a concentration of charcoalflecking. Approximately 10-m south of ST 1, ST 2 also contained a dense concentration of cultural material, including two wire nails, a staple, a miscellaneous ferrous metal fragment, a brass eyelet, a metal button, an earthenware sherd, a bone fragment, a brown bottle lip sherd, and six clear vessel glass sherds. The profile of ST 2 revealed complex cultural stratigraphy with two disparate sterile strata above the stratum containing artifacts, and like ST 1, charcoal flecking was concentrated at the interface betweentheartifactladencultural deposit and the underlying sterile subsoil (Figure 4-4). ST 3 , approximately $15-\mathrm{m}$ south of ST 2, contained significantly less cultural material. A single earthenware sherd and one clear vessel glass sherd were recovered. No charcoal was present in ST 3.

Approximately 40-m west of shovel test 2, ST 5 contained two wire nails and an earthenware sherd. ST 5 was located near the center of the playground clearing and the soil was remarkably

Figure 4-2. 41FT279 site map.

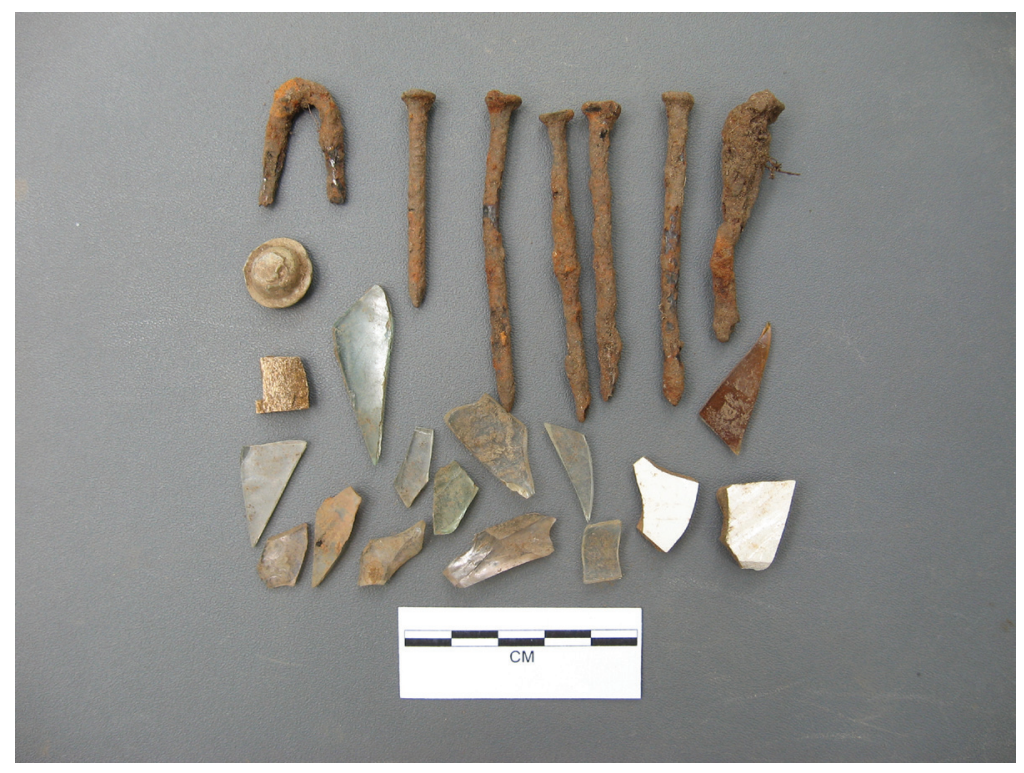

Figure 4-3. Artifacts from ST 1.

shallow. Cultural materials recovered from ST 1, 3 , and 5 were found at $0-20 \mathrm{cmbs}$, and in ST 2, cultural materials were recovered $22-34 \mathrm{cmbs}$. On the northern edge of the site, near Springfield Campsite numbers 12 and 17, a light scatter of 


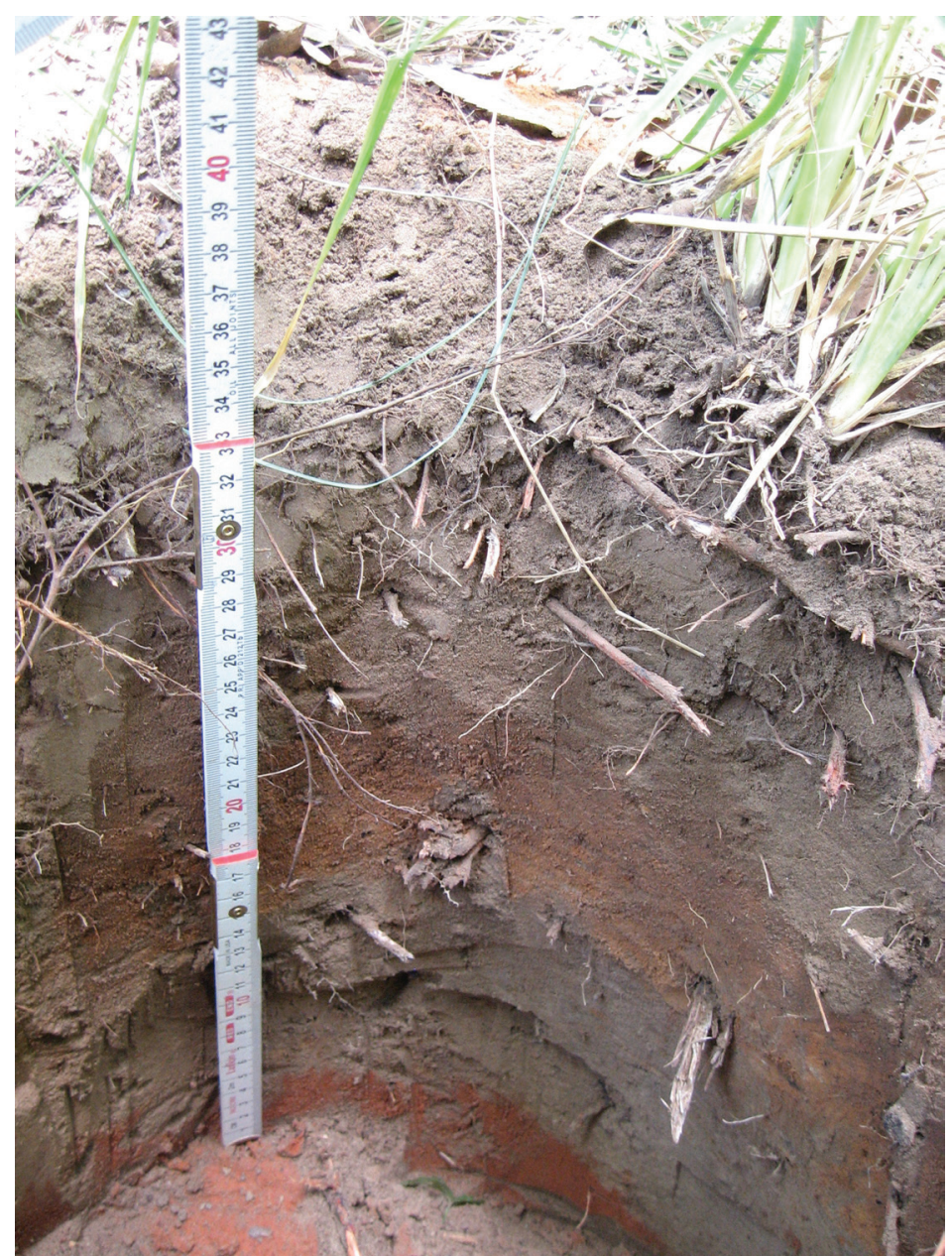

Figure 4-4. Profile of ST 2 showing complex, cultural stratigraphy.

\section{Conclusions/Recommendations}

A majority of land surrounding this historic structure has been developed by the park for several patron amenities, and thus, 41FT279 has been severely disturbed. However, in the small copse of trees, cultural stratigraphy is intact, and further investigations could prove useful in identifying the occupants of this historic site. As such, 41FT279 is classified as a Level 2 site (Moderate to High Management Priority). Currently, 41FT279's eligibility for National Register of Historic Places (NRHP) nomination or State Archaeological Landmark (SAL) designation is unknown. Due to the site's moderate to good research potential, further eligibility testing will be necessary if future projects will impact the site.

\section{FT280}

artifacts was visible on the surface, but the artifacts were neither collected nor photographed.

Prior to the construction of the park, the land on which 41FT279 is located was occupied by a number of different families. The Hills were the most recent occupants (1891-1968), but prior to them, the Oliver and Stroud families settled there (Jasinski 2002). Artifacts found on the surface by the SFA crew and in the shovel test probes by CAS archaeologists suggest that this homestead dates from the late-nineteenth to early-twentieth century. Though the site cannot be determined as the house of the Hill family, it dates to the early period of their occupation of the land.
Located on a gentle, westerlytrending slope on the east side of the park, 41FT280 is an expansive historic site defined by surficial artifacts and features, as well as subsurface cultural deposits. 41FT280 measures approximately 85-m (N/S)-x-200-m (E/W) and covers both wooded areas and clearings (Figure 4-5). Site boundaries are delineated to the east by Park Road 64 and to the north, south, and west by sterile shovel tests (Figure 4-6). Oaks are the prominent species of tree. Edge fine sandy loam (EgE) supports a thick understory of various shrubs, vines, and patchy grass.

41FT280 was discovered in 1972 by TPWD archaeologist, George Kegley, and the site was revisited in 1983 and 1990 by TPWD 
archaeologists. 41FT280 has been referred to as the "Stage Coach Stop" by previous TPWD and SFA investigations. A scenic trail skirts the site's southern boundary, and a fishing pond for children has been constructed in the eastern portion of the site.

\section{Levels of Work and Results}

In 1996, the SFA crew revisited 41FT280 and delineated the western boundary of the site by excavating two shovel tests. Of the two shovel tests, one was positive and the other

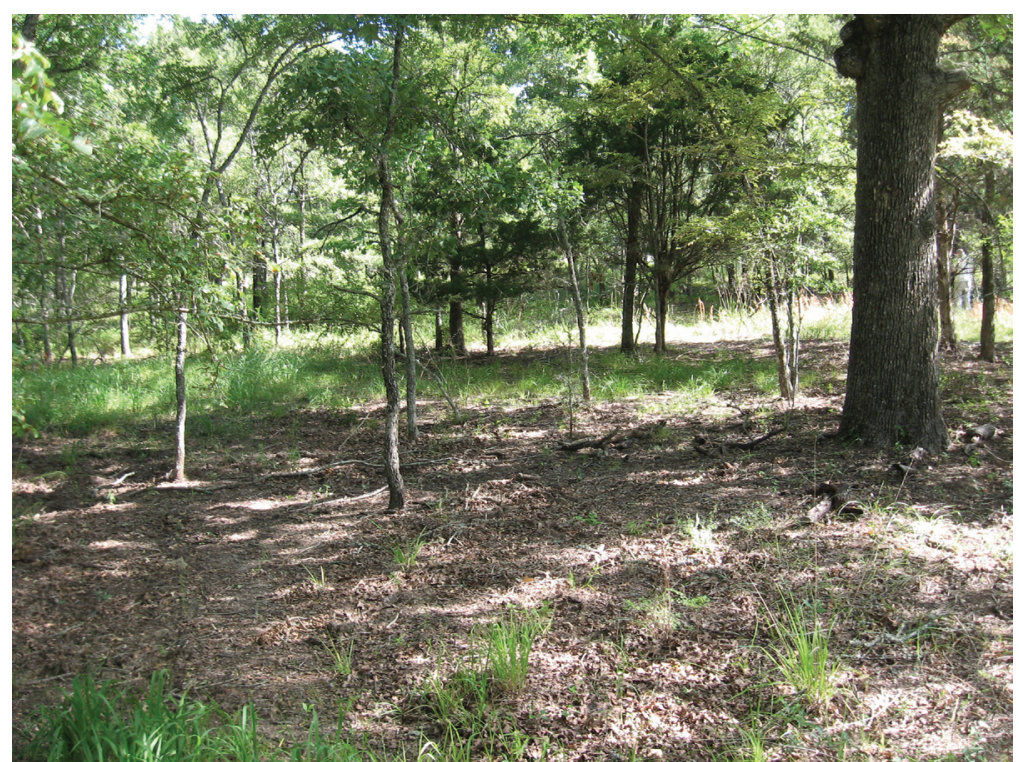

Figure 4-5. Overview of site 41FT280; photographed facing east. negative, but it is not certain whether the single earthenware rim sherd collected came from the shovel test or from the surface. The field map drawn by an SFA crew member indicates that there were several concentrations of surficial artifacts, as well as two depressions that were determined to be erosional in origin. CAS archaeologists' investigation of the erosional depressions FIGURE 4-6. REDACTED revealed that they are, in fact, cultural features. Upon careful inspection, the larger, eastern depression looked to be square in shape $\left(2.5 \mathrm{~m}^{2}\right)$, and the western depression appeared to be rectangular (2-x-3-m). A shovel test (ST 1) was excavated in order to investigate subsurface deposits. This test revealed partially glayed, hydric soils extending to at least a depth

of $50 \mathrm{cmbs}$. Two brick fragments were observed in the profile of ST 1 between 15 and $25 \mathrm{cmbs}$. ST 2 was placed approximately 5-m south of ST 1 on a mound of sediment that looked to be associated with the square depression. Three cut nails and a fragment of a brass buckle were recovered from ST 2. The profile of ST 2 revealed that there was a clay cap, composed of sediments similar to 
those that were excavated from ST 1, on top of a stratum with cultural material with underlying sterile subsoil; the cultural deposit buried by sterile subsoil confirms the anthropogenic nature of the depression and spoil pile. On the surface in the vicinity of the two depressions, three lowfired brick fragments, one of which was saltglazed, were observed (Figure 4-7).

CAS archaeologists delineated the northern and southern boundaries with shovel tests (ST 3 and ST 4) at the extent of surficial cultural materials. A porcelain insulator and a stamped bottle glass base sherd were collected by CAS archaeologists, as was the brass buckle fragment from ST 2. These artifacts, along with others that were visible on the surface and in shovel tests, suggest an occupation of the site from the late-nineteenth century well into the twentieth century.

\section{Conclusions/Recommendations}

Aside from the fishing pond, 41FT280 has not been disturbed significantly. Given intact soils (inside the tree line), cultural surface features, and probable nineteenth century occupation, 41FT280 has been classified as a Level 1 site (High Management Priority). This site has good to excellent research potential, and it is recommended as eligible for NRHP nomination or SAL designation. If this site cannot be protected from future developments, data recovery may be necessary to offset the loss of information.

\section{FT408 and 41FT409}

41FT408 is a historic site with surface and subsurface cultural material, ornamental plants, and possible agricultural landscape modification. The site occupies the gently sloping top of a northerly-trending ridge in the northeastern portion of the park. Aside from a large oak tree and grapevines at the center of the site, 41FT408 is located in a field with abundant, tall grasses (Figure 4-8). Surface visibility is less than 10 percent, but the vegetation is managed by park personnel with an occasional controlled burn. Fourteen shovel tests excavated by the SFA crew in 1996 delineate 41FT408's boundary. The site measures approximately 37-m (N/S)-x-50-m (E/ W) (Figure 4-9).

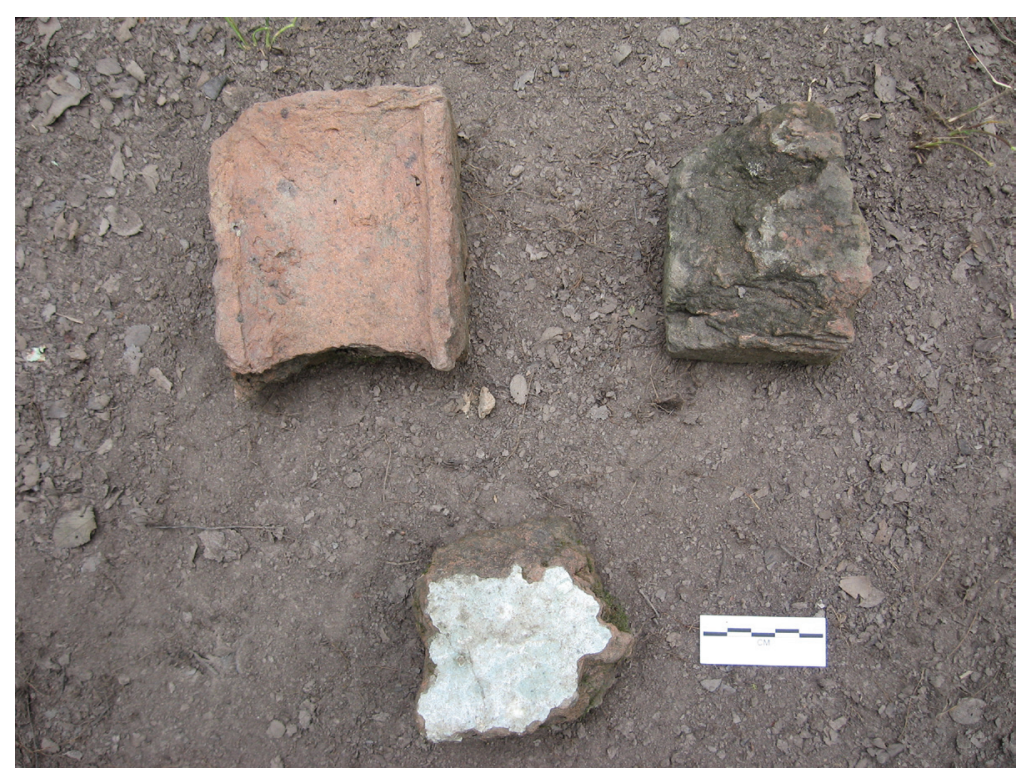

Figure 4-7. Low-fired bricks found on the surface near the two depressions.
41FT409 is a historic dump approximately 40 -m northeast of 41FT408 (see Figure 4-9); the two sites are probably associated with each other. 41FT409 occupies a portion of the western slope of the same northerly-trending ridge and is found just within a tree line. Defined by the extent of surficial historic debris, 41FT409 measures approximately 20$m$ (N/S)-x-25-m (E/W). Two intersecting, deep historic road cuts are adjacent to the north of the dump, and between sites 41FT408 and 41FT409, there 


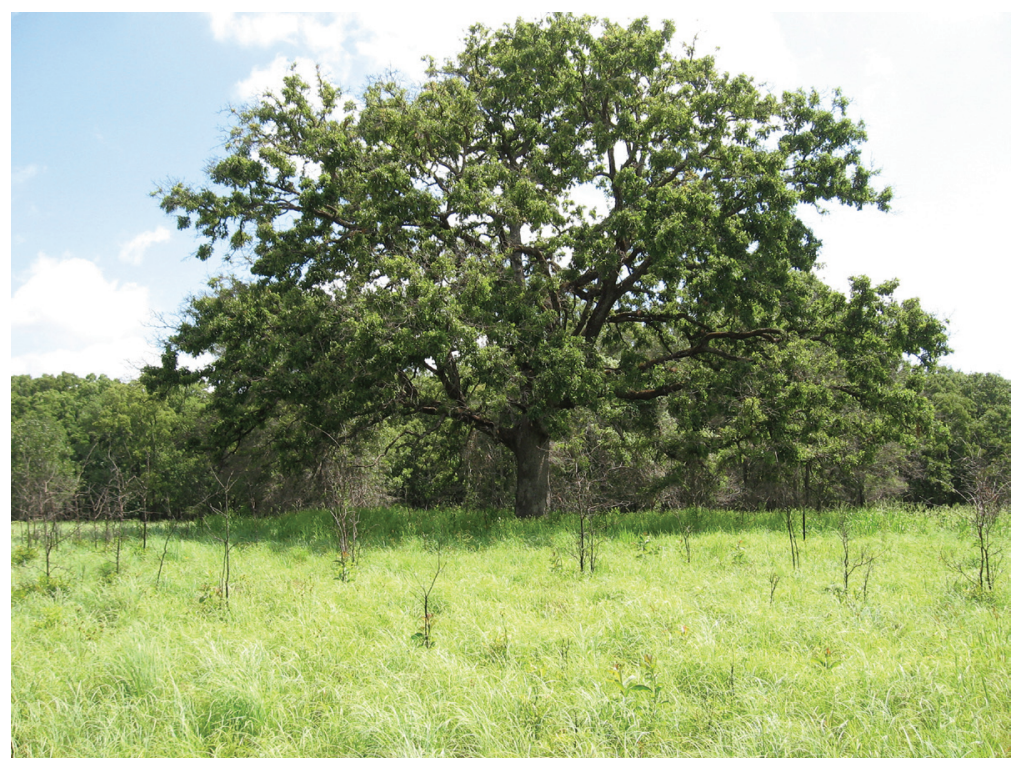

Figure 4-8. 41FT408 overview; photographed facing east.

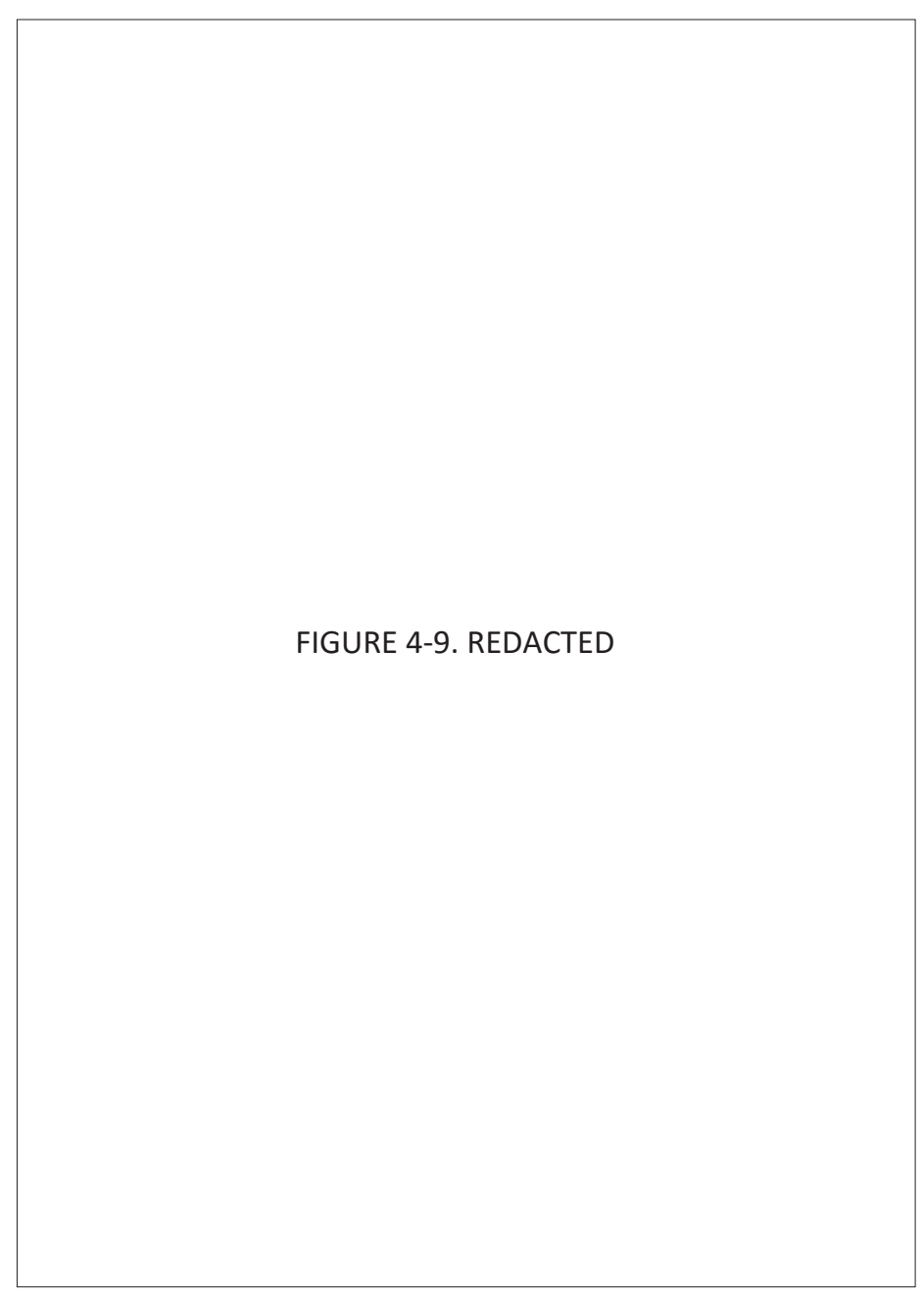

Figure 4-9. 41FT408 and 41FT409 site map. is a shallow, linear ditch and hummock running north-south (Figure 4-10). Tabor fine sandy loam $(\mathrm{TaB})$ is the soil mapping unit within which both of the sites are located.

Sites 41FT408 and 41FT409 may have been discovered prior to 1980 , but the earliest record of them comes from the results of a survey Dr. James E. Corbin performed on behalf of Prewitt and Associates, Inc.

\section{Level of Effort and Results}

In 1996, the SFA field crew revisited sites 41FT408 and 41FT409; their levels of effort varied with each site. Site 41FT408's boundary was delineated with 14 shovel tests. Historic debris found in nine of the shovel tests included clear vessel glass, flat glass, earthenware, solarized bottle glass, low-fired brick, and cut nails. According to the field map from 1996, ornamental plants were located near grapevines. When CAS archaeologists returned to 41FT408 in 2008, no shovel tests were excavated as the site's boundary was previously well defined; instead, a surface inspection was performed and two notable features were discovered. Underneath the central, large oak tree, there is a pile of machine-made bricks with "Whiteselle, Corsicana" inscribed on them (Figure 4-11). To the north of the site, the aforementioned shallow, linear ditch and hummock, possible remnants of agricultural landscape modification, runs northsouth for approximately $80-\mathrm{m}$. The 


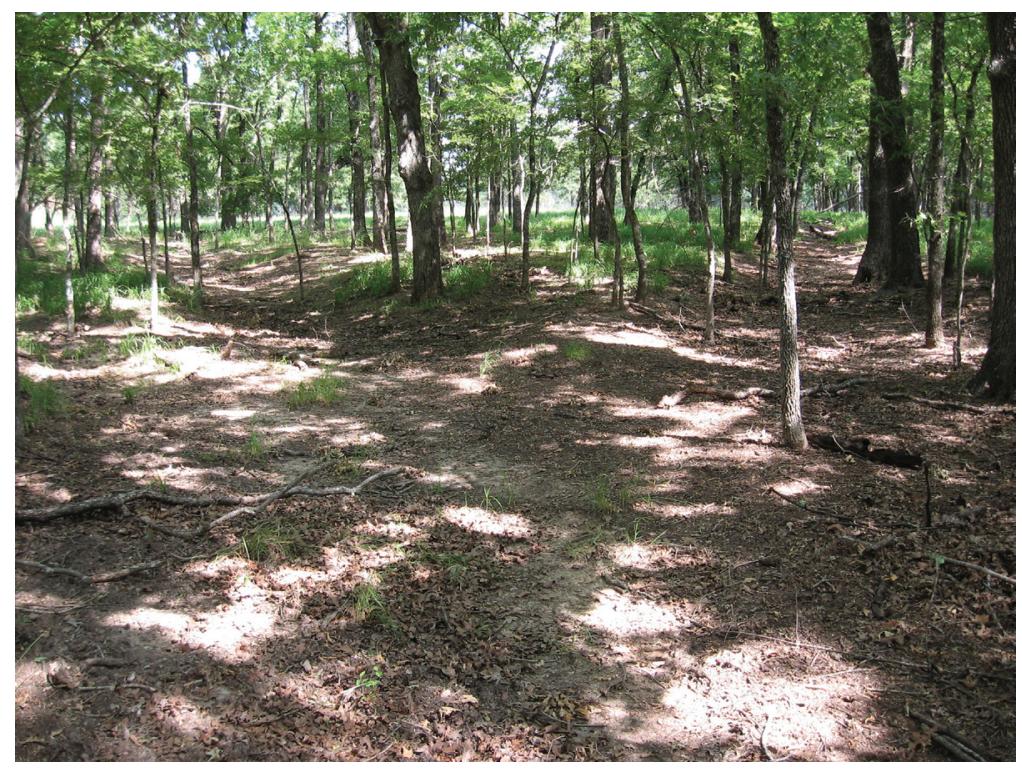

Figure 4-10. Intersecting historic road cuts northwest of 41FT409; photographed facing north.

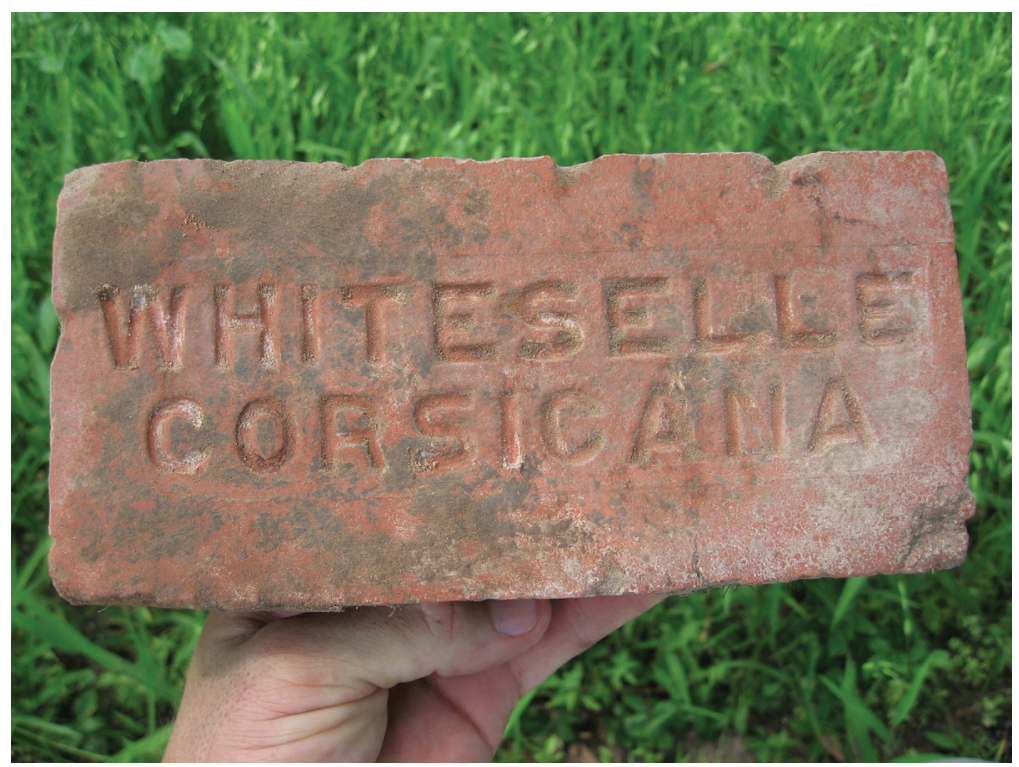

Figure 4-11. Brick from pile underneath the large oak tree at 41FT408. the site in 2008. Two deep historic road cuts that intersect approximately $25-\mathrm{m}$ northwest of the site were also observed in 1996 and 2008. One historic road cut, oriented more northsouth than the other, appears to dead end into the dump. Just inside 41FT409's boundary, near the intersection of the historic road cut and the dump, CAS archaeologists observed a linear patternoflargeferruginous rocks. The feature is approximately six meters long and the rocks range in size from $10-\mathrm{x}-15-\mathrm{cm}$ to $30-$ $\mathrm{x}-30-\mathrm{cm}$. It is not clear whether or not these rocks are a natural outcrop or a possible foundation for a structure. Other artifacts observed but not collected by CAS archaeologists included a large ceramic vessel, two ceramic mixing bowl rim sherds, enameled steel cookware, miscellaneous metal, iron stove parts, brick fragments, and glass. One rectangular, clear bottle with an Owens-Illinois maker's mark (ca. 1932-43), and two milk glass mason jar lids were collected by CAS archaeologists (Toulouse 1971).

The artifacts observed grapevines were still at the site, but possibly due to a relatively recent controlled burning; the ornamental plants were not visible.

When the SFA field crew revisited 41FT409, they made many observations, but did not collect anything. Bricks, stoneware, buggy springs, and other domestic items were present at the dump in 1996 and when CAS archaeologists revisited and collected from both 41FT408 and 41FT409 suggest that the sites were occupied from the late nineteenth century into the twentieth century, which provides support to the hypothesis that these sites are associated with each other. 


\section{Conclusions/ \\ Recommendations}

Sites 41FT408 and 41FT409 have been minimally affected by development of the park, have an abundance of artifacts, and have cultural features present. Both sites are classified as Level 1 (High Management Priority). This site has good to excellent research potential, and it is recommended as eligible for NRHP nomination or SAL designation. If this site cannot be protected from future developments, data recovery may be necessary to offset the loss of information.

\section{FT463}

Site 41FT463, a prehistoric lithic scatter, is on the base of a gentle, easterlytrending slope on a peninsula less than 40-m west of Fairfield Lake in the northeast portion of the park. A scenic hike and bike trail surrounds the site and follows the perimeter of the peninsula. The vegetation at the site consists primarily of oak and cedar. Edge fine sandy loam (EgE) also supports an understory of various shrubs, vines, and patchy grass, all of which were present in the vicinity of 41FT463 (Figure 4-12). At approximately 10 $\mathrm{m}$ in diameter, the site is small and circular in shape according to the shovel tested delineation

Figure 4-13. 41FT463 site map.

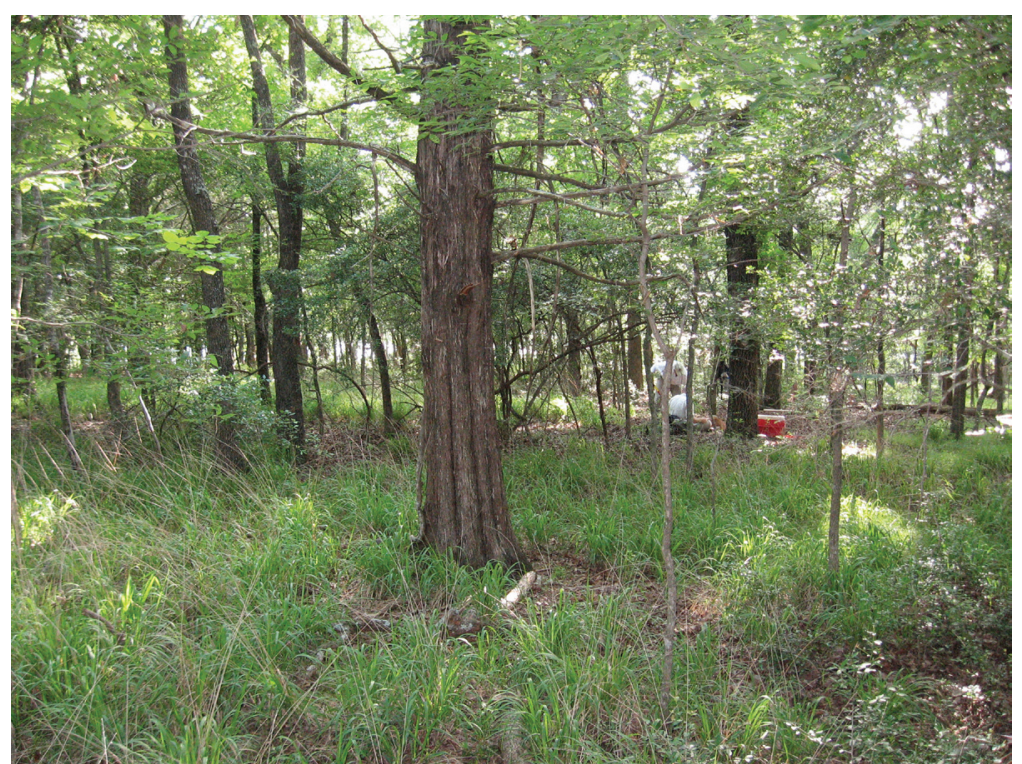

Figure 4-12. Overview of 41FT463; photographed facing east.

FIGURE 4-13. REDACTED

performed by the SFA crew in 1996 (Figure 413).

\section{Level of Effort and Results}

In 1996, the SFA field crew excavated a total of 19 shovel tests within $40 \mathrm{~m}$ of 41FT463. Only two of the shovel tests, placed approximately 
5-m apart, contained cultural material; two interior chert flakes and two possible flakes made of silicified wood were recovered. When CAS archaeologists revisited the site in 2008, two shovel tests were excavated to determine the integrity of subsurface deposits and confirm the site's boundaries. Both shovel tests were devoid of cultural material, but they revealed deep, intact sandy soils with the potential for buried deposits.

\section{Conclusions/ \\ Recommendations}

Given the low amount of cultural material but the potential for buried deposits, 41FT463 has been classified as a Level 3 site (Moderate to Low Management Priority). In the case that future construction will impact 41FT463, the location of the site should be noted. Although the site's eligibility for NRHP nomination or SAL designation is unknown, CAS recommends that the THC be allowed to comment on any work that might be necessary.

\section{FT464}

This site is a prehistoric campsite located in a clearing adjacent to State Park Road 64 near the southern boundary of the park (Figure 4-14 and Figure 4-15). The site is situated on a small ridge finger overlooking the floodplain of Little Brown Creek to the east. The recorded portion of the site measures approximately 35-m (N/S)-x-29-m (E/W). Silstid loamy fine sand (SsB) supports tall grasses, weeds, and a few hickory and oak trees. The site is marked by an access box for a cable buried.

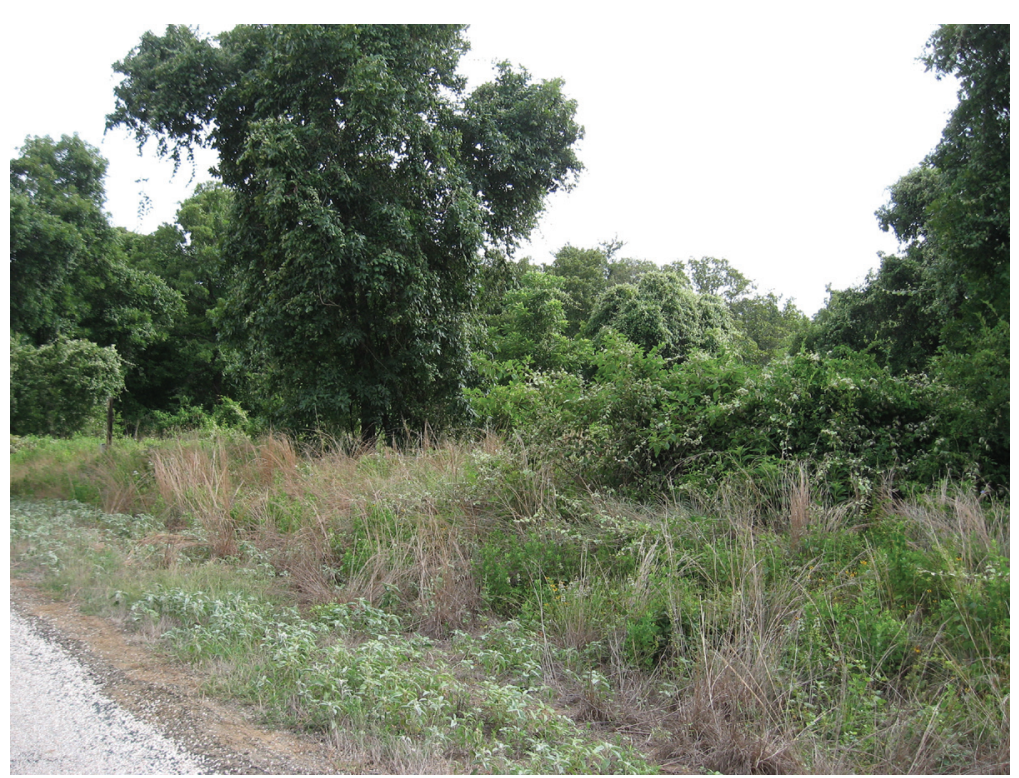

Figure 4-14. Overview of 41FT464; photographed facing north.

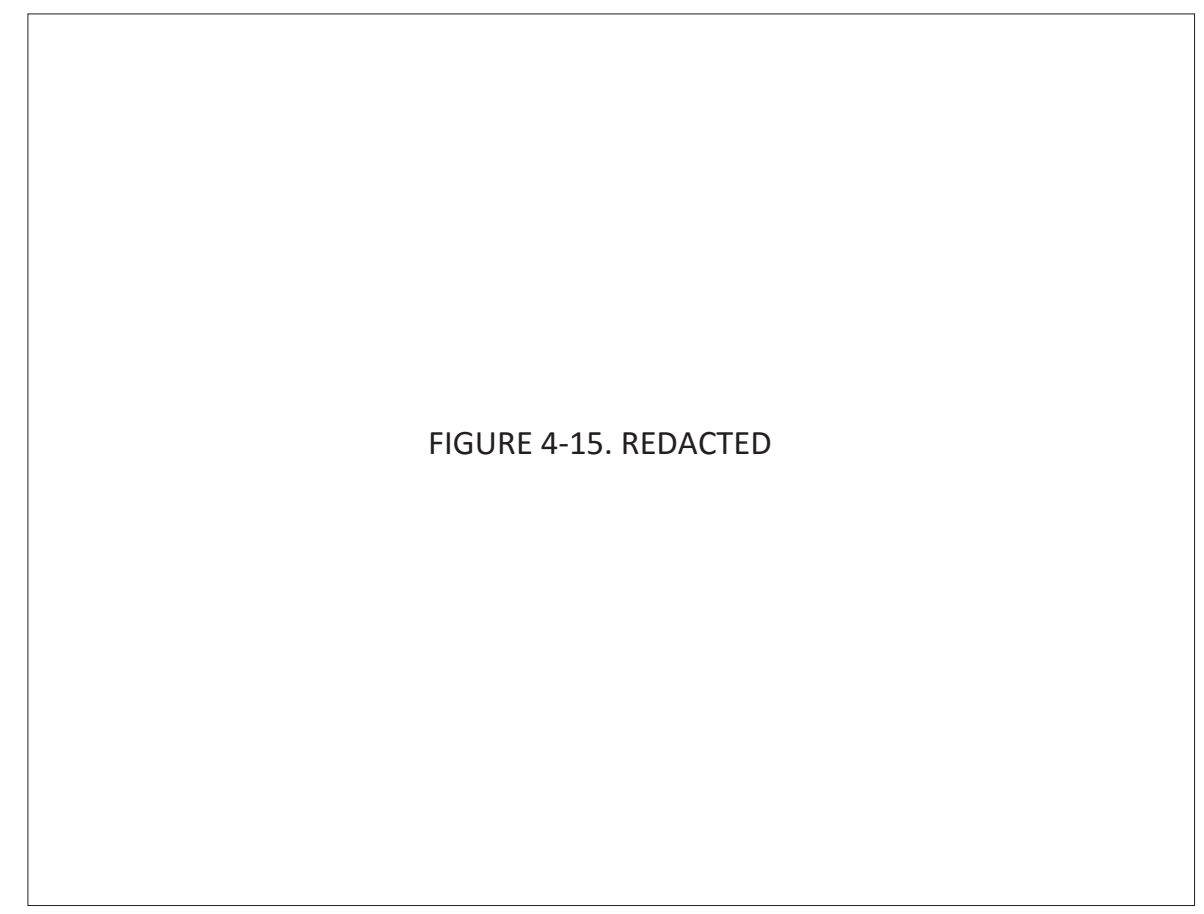

Figure 4-15. 41FT464 site map. 


\section{Levels of Work and Results}

41FT464 was discovered in 1996 during the excavation of two shovel tests in close proximity to the cable box. One of these shovel tests recovered two interior flakes and three pieces of fire-cracked rock, one of which appeared to have been intentionally pitted and may have served as a small nutting stone, which are typically attributed to Archaic and Late Prehistoric occupations (Turner and Hester 1999:308). The other shovel test recovered two interior flakes and one fire-cracked rock. The northern boundary of the site was defined by the SFA crew by five additional negative shovel tests. In 2008, CAS archaeologists excavated three additional shovel tests to determine the southern and eastern boundaries and evaluate the integrity of the site. These tests encountered a relatively deep topsoil of loamy sand overlying sandy clay subsoil at a depth of 44-56 cmbs. ST 1 recovered one interior flake and one probable fire-cracked rock at a depth of 0-20 cmbs (Figure 4-16). These artifacts were not collected. STs 2 and 3 were sterile and determined the eastern and southern site boundaries, respectively. The paved road defines the western site boundary.

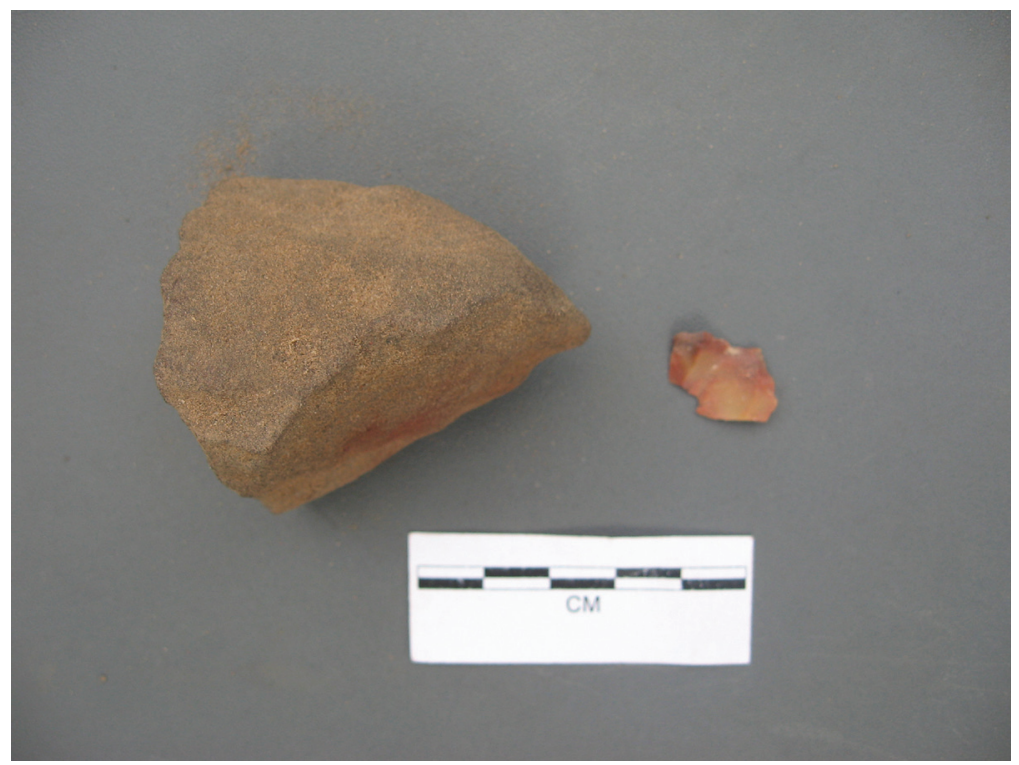

Figure 4-16. Artifacts observed in ST 1.

\section{Conclusions/Recommendations}

Site 41FT464 is a small prehistoric campsite probably dating to the Archaic and/or Late Prehistoric periods. Although the western edge of this site was probably disturbed by the adjacent road and buried cable, the remaining portions appear to be relatively intact and may contain undisturbed deposits. As such, this site may have good to moderate research value but its eligibility for NRHP nomination or SAL designation is unknown without further work. 41FT464 is classified as a Level 2 site (Moderate to High Management Priority). Further eligibility testing will be necessary if future projects will impact the site.

\section{FT465}

Site 41FT465, a prehistoric lithic scatter, is located on a cleared, easterly-trending ridge spur overlooking Little Brown Creek in the southern portion of the park. Vegetation in the vicinity of the site includes grass, various weeds, and a few small clusters of young oak and cedar trees supported by Rader fine sandy loam (RaB) (Figure 4-17). Site 41FT465, as delineated by slope to the south and sterile shovel tests to the north, east, and west, measures approximately $100-\mathrm{m}$ (N/S)-x-180-m (E/W) (Figure 418). Modern disturbances in the vicinity include a gas pipeline running north-south through the center of the site, and a stock tank constructed just east of the site boundary.

\section{Level of Effort and Results}

The SFA survey crew discovered 41FT465 in 1996. At the time of discovery, 25 shovel tests were excavated in the area 


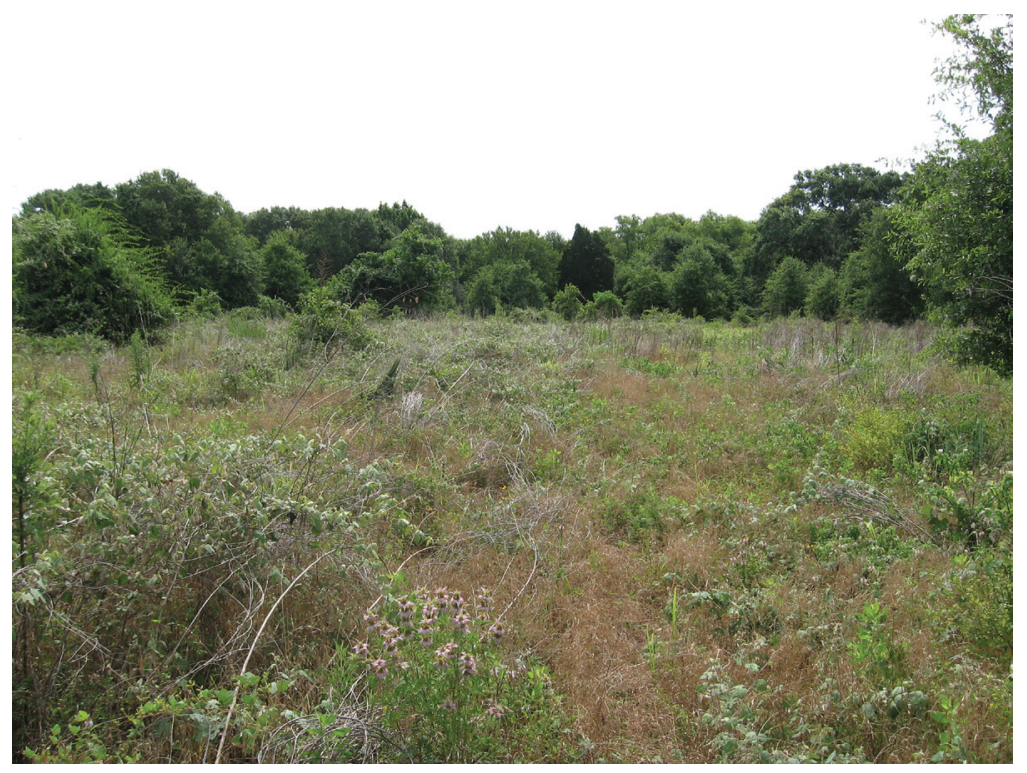

Figure 4-17. Overview of 41FT465; photographed facing east.

Archaic (ca. 2500 BC-AD 700/800) sites (Turner and Hester 1999) (Figure 4-19, Lot 1). One quartzite cobble, a ferruginous sandstone metate, and tinted, modern glass sherds were also collected from the surface by the SFA crew. In 2008, when CAS archaeologists revisited the site, two shovel tests were excavated to inspect subsurface deposits and delineate the site's northern boundary. Both shovel tests were devoid of cultural material but revealed very deep, intact sandy deposits. No artifacts were visible on the surface,

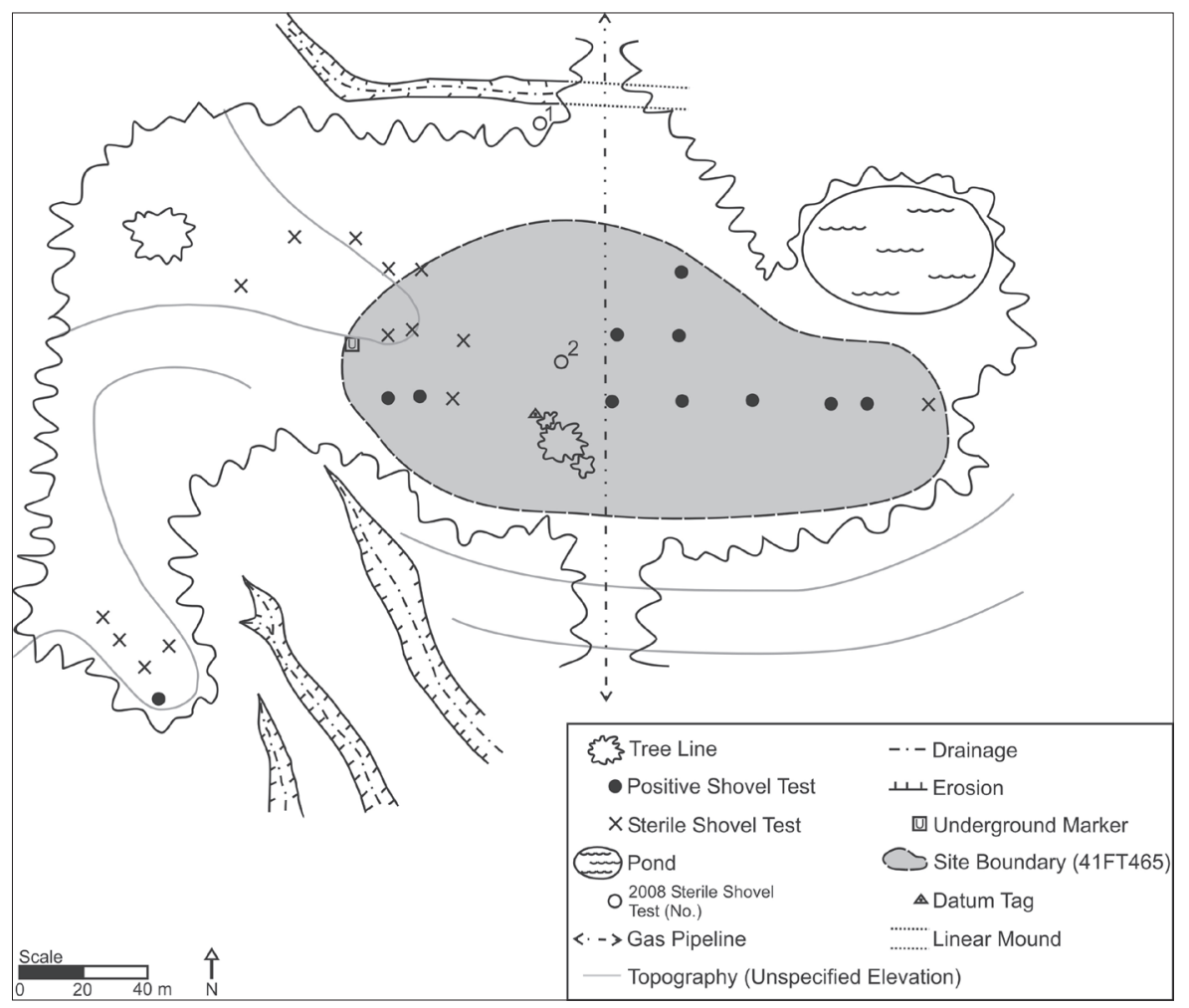

Figure 4-18. 41FT465 site map.

of the site. A total of 11 shovel tests contained cultural material, including various types of chert and quartzite debitage, acorns, and one projectile point. The projectile point collected, typed Gary, are common in East Texas Middle to Transitional but a linear mound feature was observed just north of the site. The linear feature was interpreted by CAS archaeologists to be either erosion control or a measure taken to divert surface water to the stock tank; nonetheless, it is a modern construction.

\section{Conclusions/}

\section{Recommendations}

41 FT465 is a
prehistoric lithic scatter with one diagnostic artifact dating to the Middle/ Transitional Archaic period. Although the site has been impacted by the gas pipeline and the construction of a stock tank, there appears to be the potential for buried deposits. 41FT466 is classified as a Level 2 site (Moderate to High 


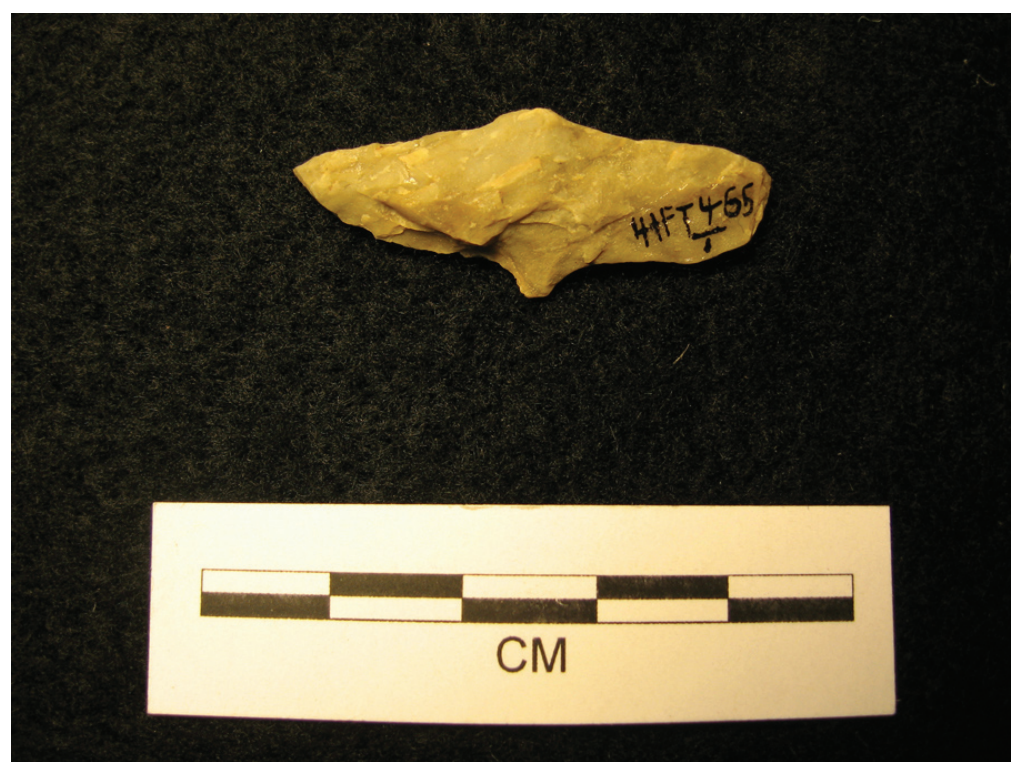

Figure 4-19. Gary projectile point recovered from 41FT465 (Lot 1).
21). It is almost certain that the park road impacted the site, and to the west of the road, there is another subsurface disturbance in the form of a buried high voltage line.

\section{Level of Effort and Results}

In 1996 when the SFA crew discovered 41FT466, they excavated 20 shovel tests and observed three surficial artifact concentrations. Of the 20 shovel tests excavated, four contained cultural material, including brown vessel glass, chert debitage, earthenware, andbrown Management Priority), but the site's eligibility for NRHP nomination or SAL designation is unknown. Further eligibility testing will be necessary if future projects will impact the site.

\section{FT466}

Situated on top of a grassy knoll between Big Brown Creek and Little Brown Creek in the center of the park, 41FT466 is a scatter of historic artifacts. The site is marked by three massive oak trees along the paved park road (Figure 420). The paved park road bisects the site; to its east, there are oak trees and a grassy knoll, and to the west, tall weeds, shrubs, and young trees constitute the vegetation. 41FT466 is located on the cusp of soil mapping units Tabor fine sandy loam $(\mathrm{TaB})$ and Edge fine sandy loam (EgE). The boundary of the site, delineated by surficial artifacts and shovel tests containing culturalmaterial, measures approximately $115-\mathrm{m}$ (N/S)-x-125-m (E/W) (Figure 4-

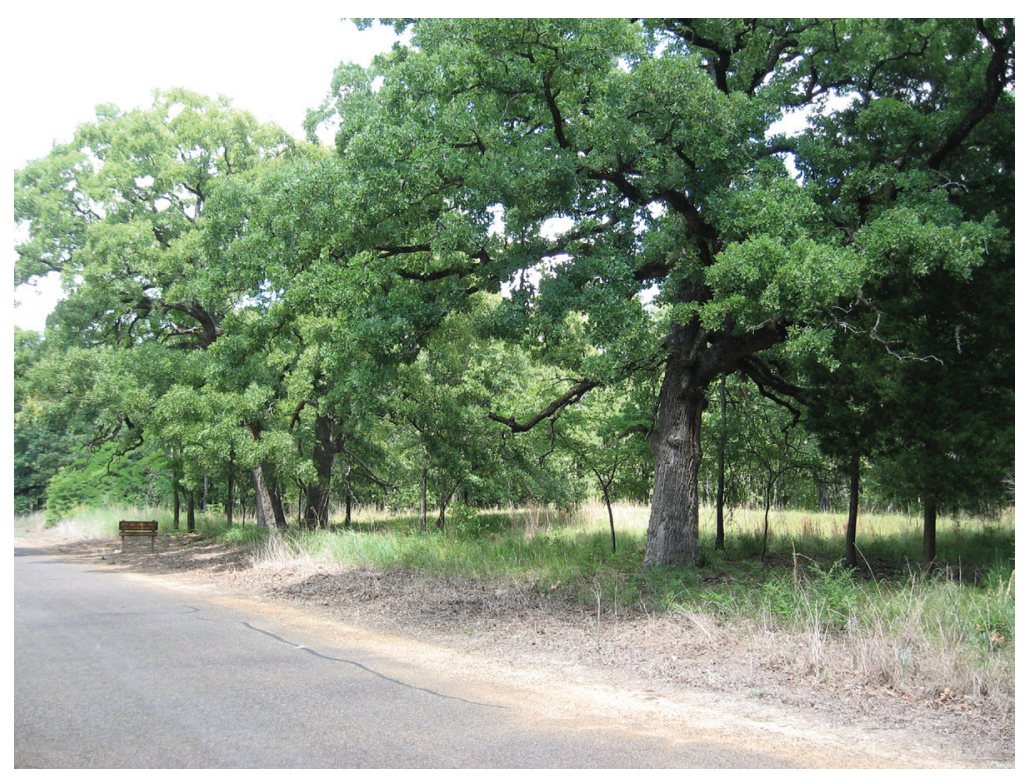

Figure 4-20. Overview of 41FT466; photographed facing northeast. 
was observed in the southeast corner of the site in both 1996 and 2008. When CAS archaeologists revisited 41FT466, surface visibility across the site was generally low, less than five percent. Despite the poor surface visibility, CAS archaeologists observed machinemade and low-fired brick, whiteware sherds and bottle glass. One small, FIGURE 4-21. REDACTED

Figure 4-21. 41FT466 site map.

broken bottle with

an Owens Bottle Co. maker's mark (ca. 1911-29) was collected (Toulouse 1971). No shovel tests were excavated in 2008 as the site was previously well-defined by the SFA crew.

\section{Conclusions/Recommendations}

The presence of both prehistoric and historic artifacts at 41FT466 complicates the dating of the occupation(s). Non-diagnostic lithic artifacts collected by the SFA crew do not clearly discern a time period of prehistoric occupation, but historic debris suggest that the site was occupied around the turn of the twentieth century. Although 41FT466 was almost certainly impacted by the construction of the park road and the buried high voltage cable, remaining portions of the site have a good potential to yield valuable information concerning early-twentieth century occupation of the area, and thus, the site is classified as a Level 2 site (Moderate to High Management Priority). Without further investigations, the site's eligibility for NRHP nomination or SAL designation is unknown. Further eligibility testing will be necessary if future projects will impact the site.

\section{FT467}

This site is a small, prehistoric lithic scatter located in the western portion of the park now designated as a primitive camping area (Figure 422 and Figure 4-23). 41FT467 is situated on a low rise on the point of a bifurcated ridge overlooking Fairfield Lake. The site measures approximately 20-m (N/S)-x-37-m (E/W). The point of the ridge, marked by the intersection of old barbed wire fencing, is a wooded area composed of mixed hardwoods with oak predominating. Edge fine sandy loam (EgE) also supports dense undergrowth of young cedar, briar, shrubs, and small patches of grass. Surface visibility is 10 percent or less.

\section{Levels of Work and Results}

Site 41FT467 was identified by artifacts from four positive shovel tests excavated in 1996 by the SFA survey crew. The materials recovered 


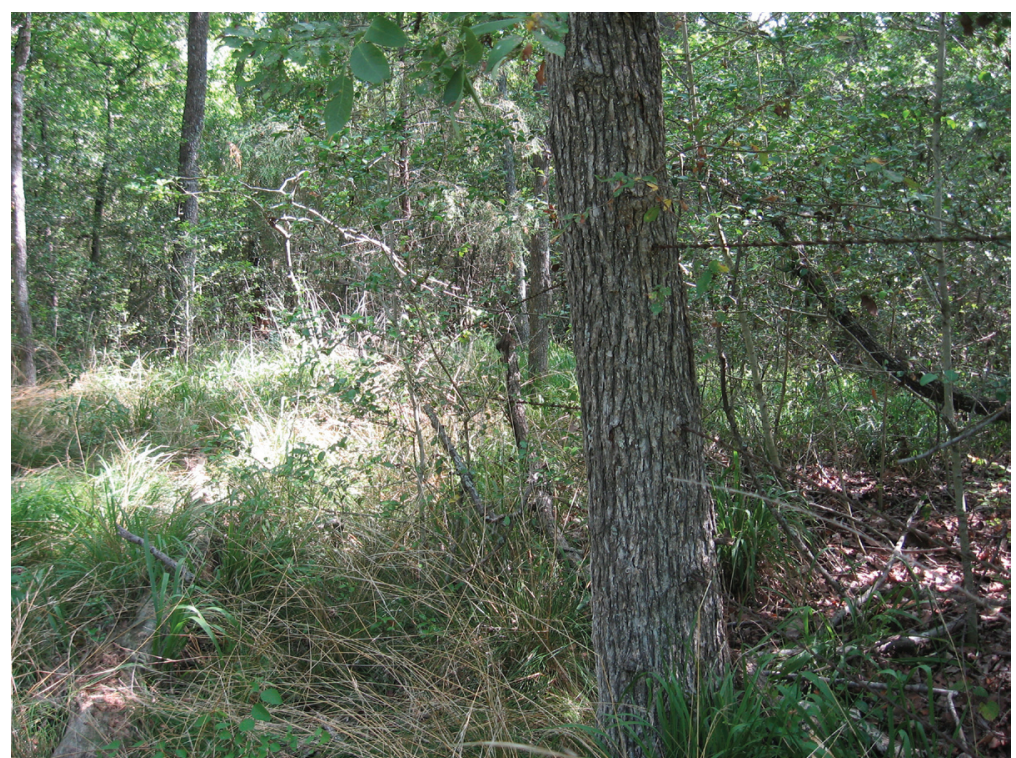

Figure 4-22. Overview of 41FT467 showing barbed wire fence; photographed facing north.

FIGURE 4-23. REDACTED

Figure 4-23. 41FT467 site map. from this site were reportedly recovered at depths of 20-72 cmbs and include one early stage chert biface, an interior chert flake, an interior quartzite flake, an exterior quartzite flake, a possible flake of silicified wood, and a quartzite cobble. The boundaries of the site were determined by sterile shovel tests. In 2008, CAS archaeologists excavated one shovel test to evaluate the site's integrity. This shovel test encountered deep loamy sands overlying sandy clay subsoil at $76 \mathrm{cmbs}$. A chert thermal spall, possibly cultural in origin, was recovered but not collected from an approximate depth of $50 \mathrm{cmbs}$.

\section{Conclusions and Recommendations}

41FT467 is a small prehistoric lithic scatter or possible campsite of unknown age. Although diminutive in size, the site appears to contain deeply buried cultural deposits. As such, this site may have good research potential. Site 41FT467 is classified as a Level 2 site (Moderate to High Management Priority). Its eligibility for NRHP nomination or SAL designation is unknown without further investigations. Further eligibility testing will be necessary if future projects will impact the site.

\section{FT468}

Located on the crest of a northwesterlytrending ridge, 41FT468 is a lithic scatter with a low amount of historic debris. The site overlooks Fairfield Lake and is located in the center of the Post Oak Campgrounds. 
A paved road and campsites confine the site to a relatively small area (Figure 4-24). As delineated by shovel tests, the site measures approximately 30 m (N/S)-x-35-m (E/W) (Figure 4-25). The vegetation at 41FT468 consists primarily of young oak trees, various shrubs, and thick, bunch grass supported by Edge fine sandy loam (EgE).

\section{Level of Effort and Results}

The SFA survey crew discovered 41FT468 in 1996, and they delineated the site boundary with 13 shovel tests. Of the 13 shovel tests, six contained cultural material, including one chert biface, cut nails, miscellaneous metal, clear vessel glass, a quartzite cobble, an interior chert flake, and a possible flake made of silicified wood. All of this material was collected. The chert biface is a probable projectile point tip, but it is not clearly discernible nor is it diagnostic. When the site was revisited in 2008 by CAS archaeologists, a single shovel test was excavated in order to investigate subsurface deposits and the western extent of the site. This shovel test yielded cultural material, including two chert flakes and one coarse chert biface (Figure 4-26); no artifacts were found deeper than $60 \mathrm{cmbs}$ in this shovel test. The shovel test also revealed that the sediments at the site were deep $(100+\mathrm{cmbs})$ and appeared intact. No artifacts

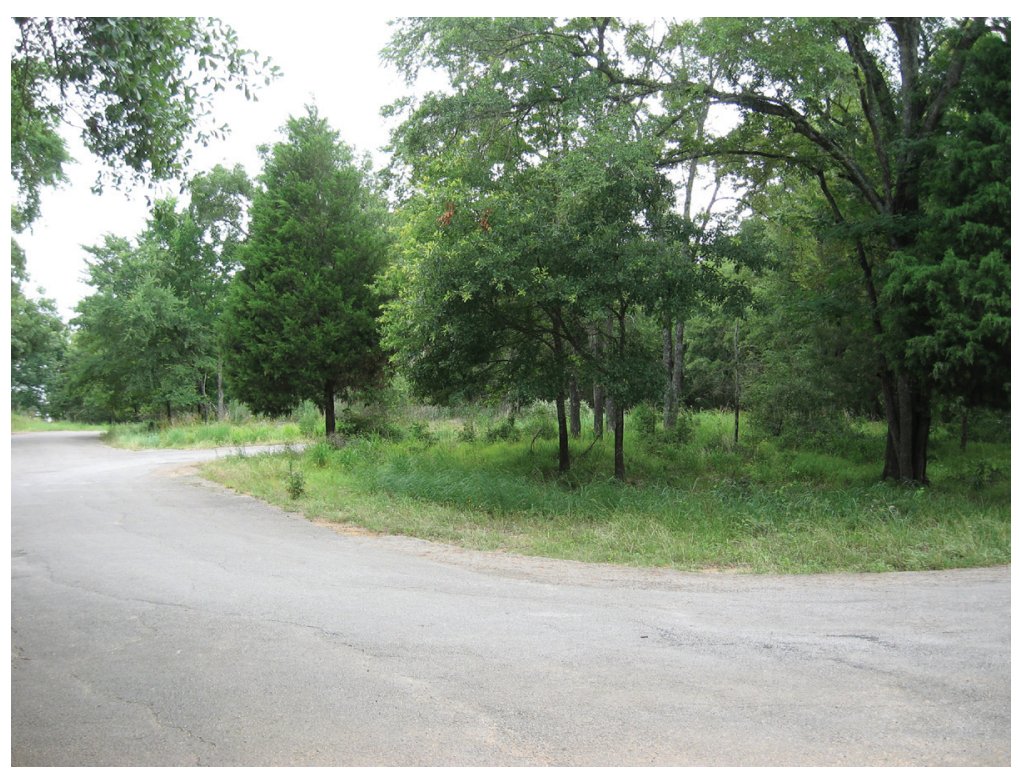

Figure 4-24. Overview of 41FT468; photographed facing north.

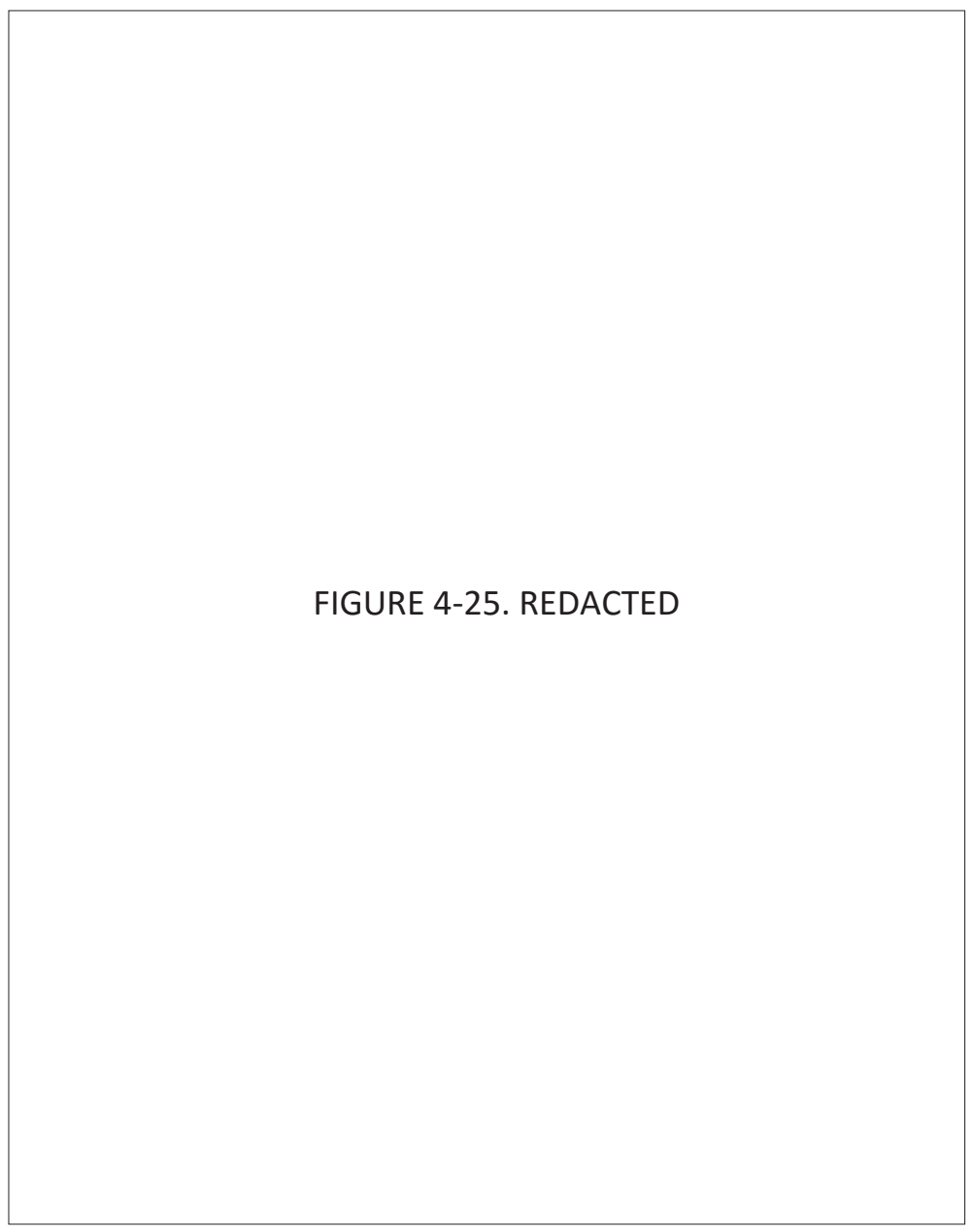

Figure 4-25. 41FT468 site map. were observed on eroded and/ 


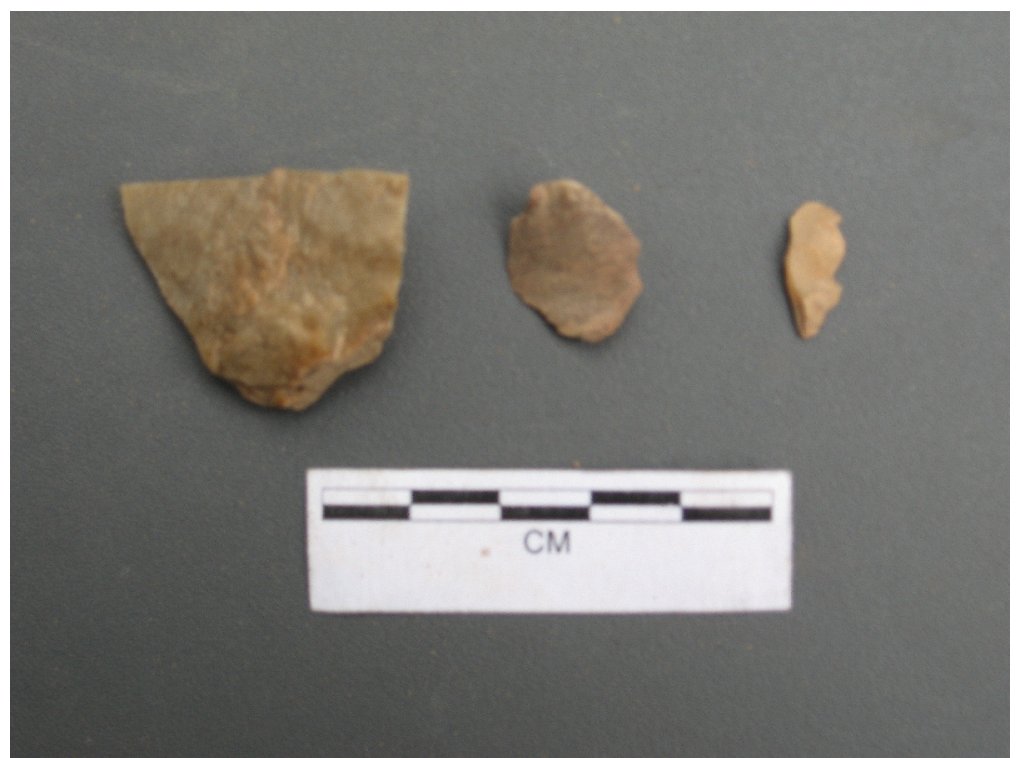

Figure 4-26. Artifacts observed in ST 1.

or disturbed surfaces adjacent to the site. CAS archaeologists did not observe any historic cultural material.

\section{Conclusions/Recommendations}

The absence of diagnostic lithic artifacts and the presence of historic material make it unreasonable to discern a distinct prehistoric occupation at 41FT468. Cut nails date the historic component of the site to the midnineteenth century at the earliest. Where not disturbed by park developments, the site appears to have maintained subsurface integrity. As such, 41FT468 has good research potential and is classified as a Level 2 site (Moderate to High Management Priority). Without further work, the site's eligibility for NRHP nomination or SAL designation is unknown. Further eligibility testing will be necessary if future projects will impact the site.

\section{FT469}

Site 41FT469 is a historic dump that occupies a westerly sloping hillside in the southeast portion of the park. The site area is primarily wooded, but the western edge of the site extends into a small clearing (Figure 4-27). Vegetation at the site consists of young oak and cedar trees and a light understory of shrubs and vines supported by Nahatche-Hatliff (NH) association soils. At the base of the hill, bioturbation in the form of hog rooting and wallowing is present. As delineated by the extent of historic material visible on the surface, 41FT469 measures approximately 25-m (N/S)-x35-m (E/W) (Figure 4-28).

\section{Level of Effort and Results}

In 1996, the SFA crew discovered this site and delineated the boundary by the extent of historic material present on the surface. No shovel tests

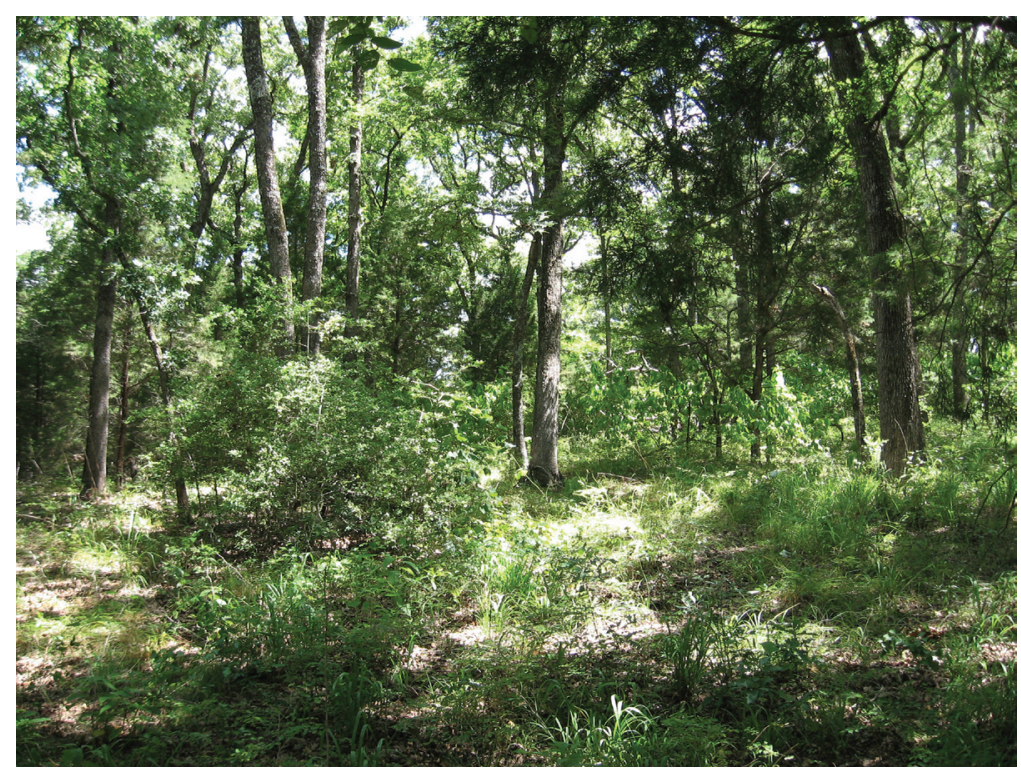

Figure 4-27. Overview of 41FT469; photographed facing north. 
were excavated in the vicinity in 1996 or 2008. The SFA crew collected a number of artifacts, including plain earthenware, a glass rod, snuff bottle fragments, miscellaneous metal fragments, bottle glass fragments, an earthenware sherd with a partial/ unidentifiable maker's mark, a handpainted earthenware sherd, yelloware, and a stoneware sherd with Albany slip. In addition to the artifacts collected, the SFA crew observed a large piece of a plow and a large petrified wood log. In 2008, CAS archaeologists revisited the site. Historic debris was still in abundance and visible on the surface (Figure 4-29). Artifacts observed included various types of glass sherds, a metal wash tub, the petrified log, and earthenware sherds; the plow was not located. CAS archaeologists collected a single artifact: an aqua bottle glass base sherd with an Adolphus Busch maker's mark (ca. 1886-1928) (Toulouse 1971). Due to the slope of the hillside and the high amount of bioturbation, the site has been severely deflated.

\section{Conclusions/ \\ Recommendations}

The variety of historic artifacts observed at and collected from 41FT469 date the site to the first half of the twentieth century and suggest that it indeed functioned as a dump. Due to the current deflated nature and low research potential of the site, 41FT469 is classified as Level 3 (Moderate to Low Management Priority). Although the site's eligibility for NRHP nomination

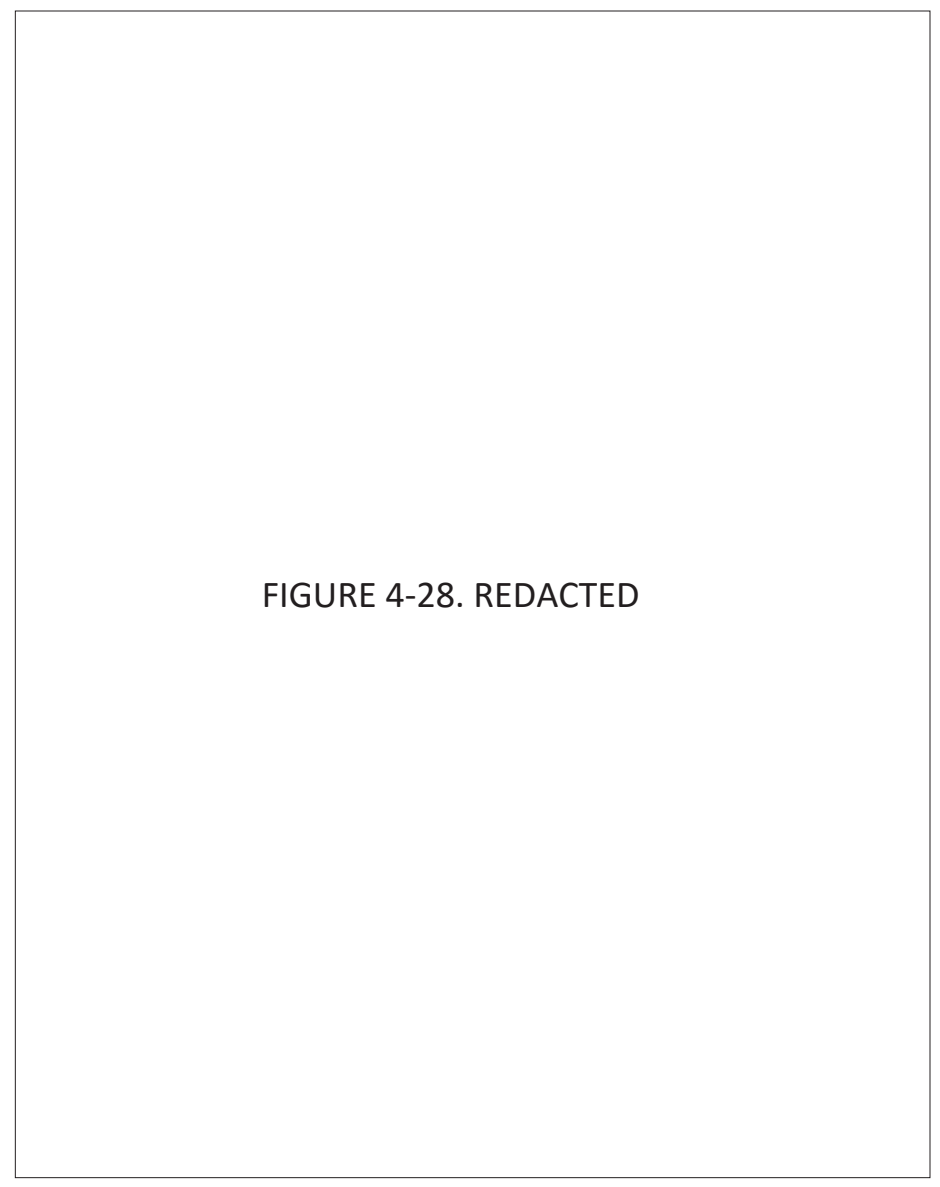

Figure 4-28. 41FT469 site map.

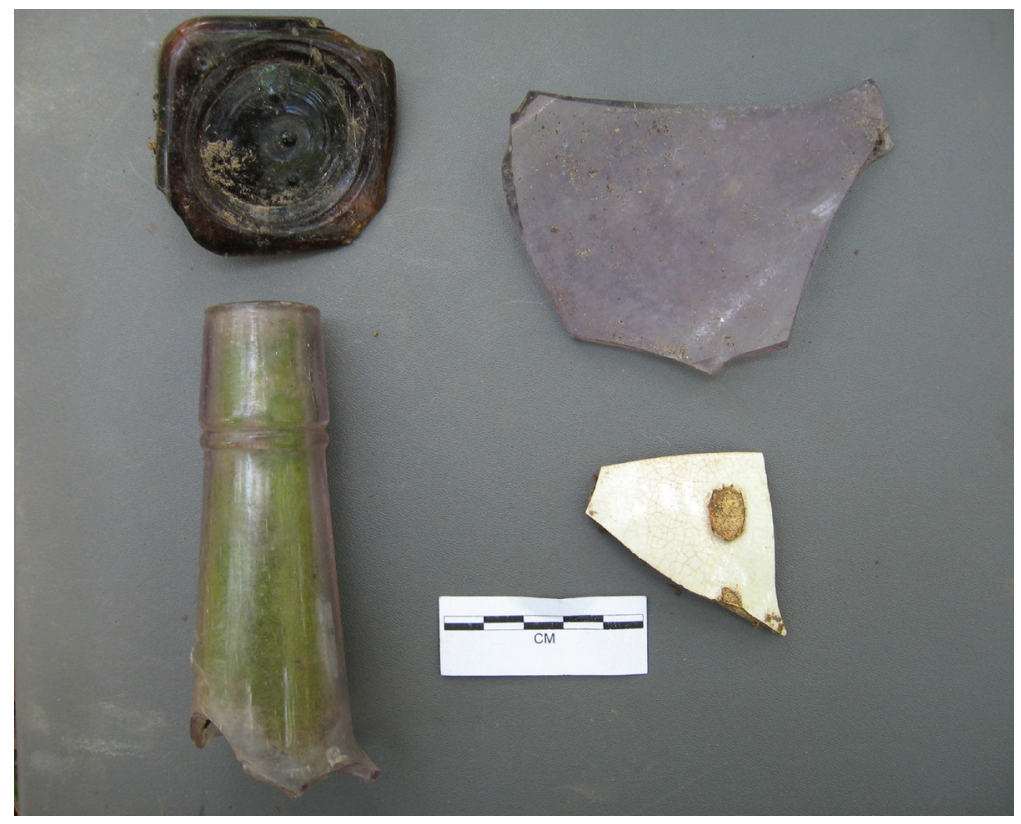

Figure 4-29. Artifacts observed on the surface at 41FT469. 
or SAL designation is unknown, CAS recommends that the THC be allowed to comment on any work that might be necessary.

\section{FT470}

Situated on a broad, flat ridge to the west of Fairfield Lake in the northwest corner of the park, 41FT470 is marked by an irregularly shaped clearing with several large oak trees near the center. The clearing is grassy with clusters of young cedar and oak trees supported by Edge fine sandy loam (EgE) (Figure 4-30). The site consists of scattered historic material and multiple surface features, and it represents a possible historic structure/homestead. The extensive distribution of surface features and positive shovel tests delineate the site's boundary; 41FT470 measures approximately 110-m (N/S)-x60-m (E/W) (Figure 4-31).

\section{Level of Effort and Results}

When the SFA crew discovered 41FT470 in 1996, they excavated a total of eight shovel tests. Four of these shovel tests contained cultural material. Only three of these initial, positive shovel tests are accounted for in the mass of artifacts collected by SFA and processed by CAS. Coincidentally, these three shovel tests contained only sherds of clear vessel glass; three sherds each for ST 1 and 2, and two sherds for ST 3.

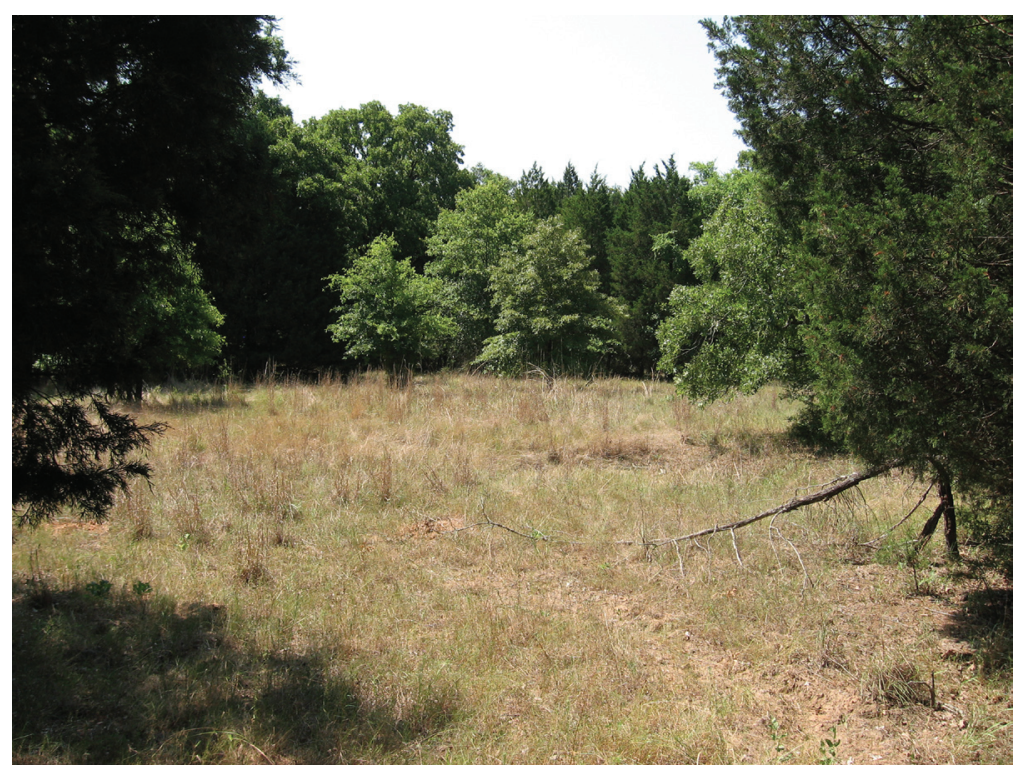

Figure 4-30. Overview of 41FT470; photographed facing east.

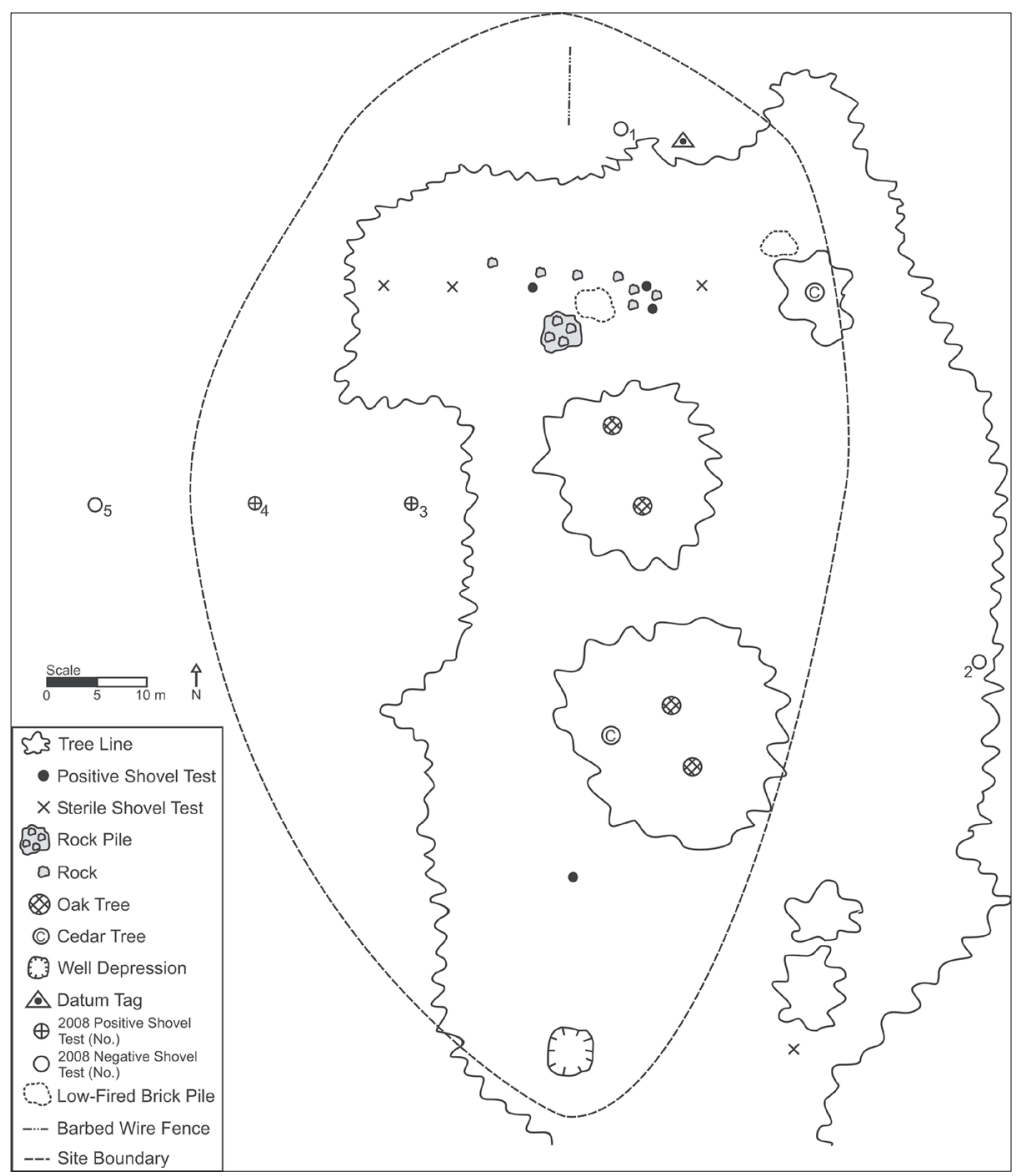

Figure 4-31. 41FT470 site map.

In addition to cultural deposits observed during subsurface testing, surface features, including a 
pile of rocks and a possible well/cistern depression were noted and mapped.

When CAS archaeologists revisited 41FT470 in 2008, amendments were made to the 1996 field map and the site's boundary was extended north and west. CAS archaeologists excavated a total of five shovel tests; two of them contained cultural material. ST 3, which was located just inside the tree line on the west side of the clearing, contained a whiteware sherd and a ferrous staple (0-16 cmbs). This shovel test reached sterile clay at $16 \mathrm{cmbs}$ and was terminated at $27 \mathrm{cmbs}$. ST 4, approximately $15-\mathrm{m}$ west of ST 3, contained a bottle glass sherd $(0-20 \mathrm{cmbs})$. ST 4 reached sterile clay at $27 \mathrm{cmbs}$ and was terminated at 34 cmbs. Both ST 3 and 4 were excavated in wooded areas with thick undergrowth. ST 5, which was approximately $15-\mathrm{m}$ west of ST 4, was sterile. ST 1 and 2, to the north and east of the site, respectively, were both sterile as well. Artifacts from the two positive shovel tests were photographed but not collected. In addition to the artifacts observed in the shovel tests, a light scatter of artifacts, including small amounts of whiteware, bottle glass, and miscellaneous metal, were visible on the surface. The pile of rocks and possible well depression, noted by the SFA crew, is still present. The rock pile is three to four meters in diameter and is composed of ferruginous sandstone (Figure 432); the possible well depression was approximately four to five meters in diameter and about $75-\mathrm{cm}$ deep. CAS archaeologists also observed two small scatters of low-fired brick and remnants of a barbed wire fence near the rock pile on the site's north side. In 2008, the site boundary was extended to the north and to the west in order to include the barbed wire fence remnant and STs 3 and 4.

\section{Conclusions/Recommendations}

The small amount of temporally diagnostic historic artifacts present at 41FT470 suggests that the site was occupied during the late nineteenth and first half of the twentieth century. Although the artifact density appears low, the scatters of low-fired brick and the pile of ferruginous sandstone suggest that the large site was probably marked by a structure. Site 41FT470 appears to have excellent research potential and is classified as a Level 1 site (High Management Priority). This site has good to excellent research potential, and it is recommended as eligible for NRHP nomination or SAL designation. In the case of future developments impacting 41FT470, further work is necessary to confirm the date and type of occupation, and to offset the loss of information.

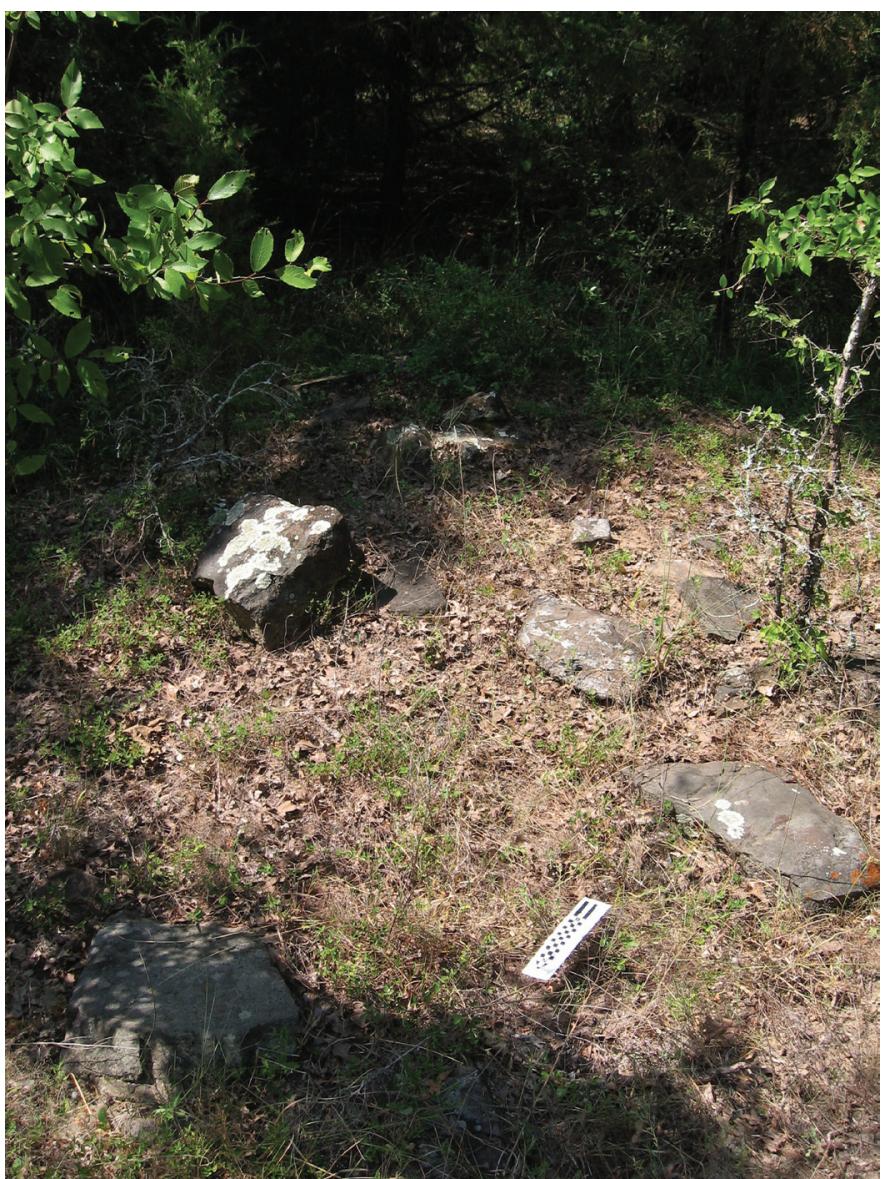

Figure 4-32. Pile of ferruginous sandstone rocks; photographed facing southeast. 


\section{FT471}

Site 41FT471 is questionable as a site. In 1996 only one prehistoric lithic artifact was recovered at the base of a ridge spur overlooking Dry Branch, a seasonal tributary of Little Brown Creek on the east side of the park. Vegetation at the site consists of dense oak and cedar trees and a sparse, grassy understory supported by Edge fine sandy loam (EgE) (Figure 433). Site 41FT471's boundary is undetermined due to the lack of a field map produced by the SFA crew and sterile shovel tests excavated by CAS archaeologists (Figure 4-34). The general location of 41FT471 was found using a topographic map with the site plotted on it.

\section{Level of Effort and Results}

In 1996, the SFA crew excavated one shovel test at the base of a ridge spur overlooking a dry drainage bed. The single shovel test was terminated at a depth of five cmbs due to clay. At or just below the surface, a single, chertybifacefragment was recovered. No other shovel tests were excavated in the vicinity

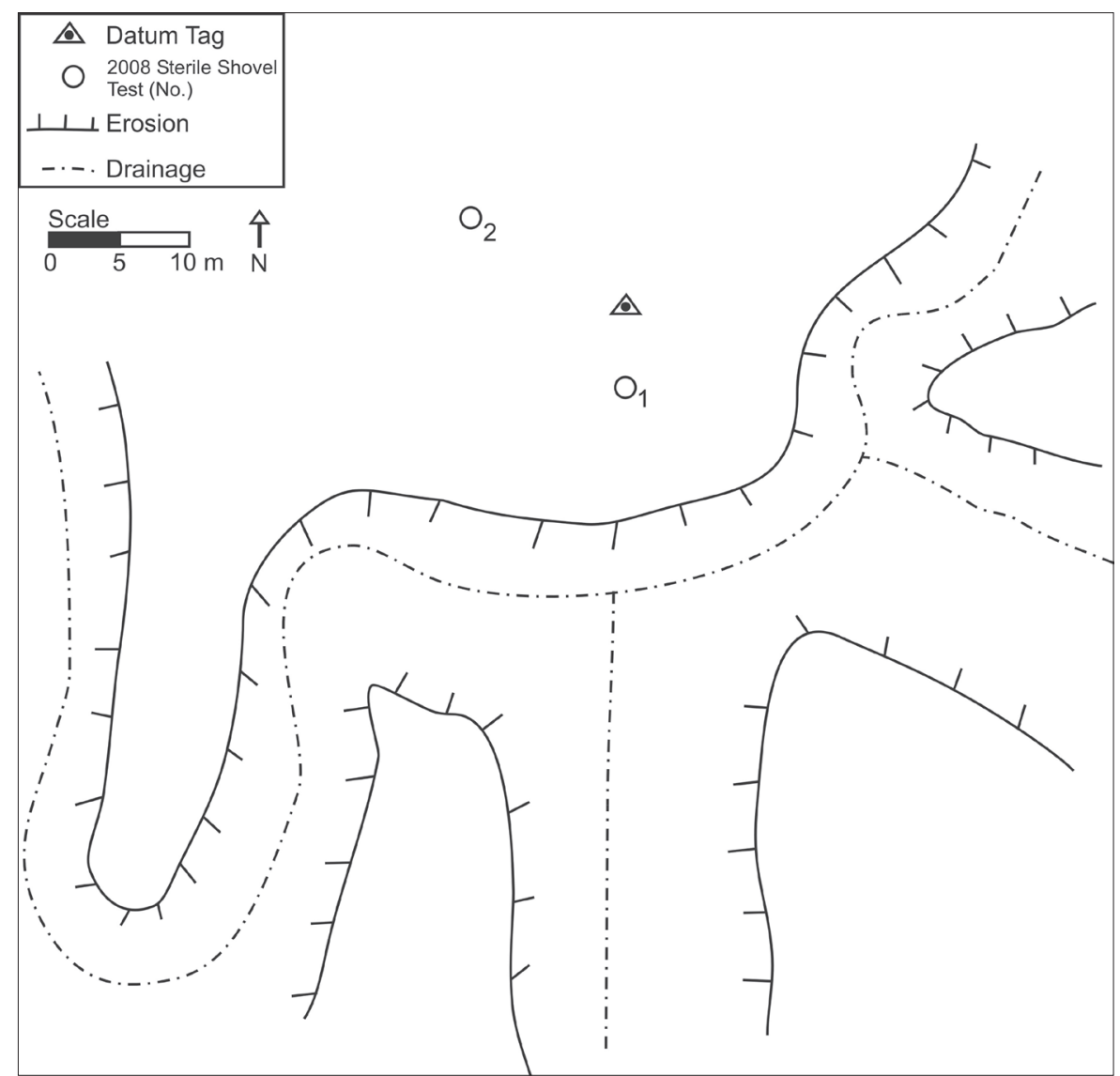

Figure 4-34. 41FT471 site map.

Figure 4-33. Overview of 41FT471 and adjacent cut bank; photographed facing east. 
excavated to investigate subsurface deposits. oak trees. A light understory of grass and shrubs Both shovel tests were devoid of cultural material are supported by Edge fine sandy loam (EgE). and encountered subsoil at 21 to 32 cmbs. CAS archaeologists proceeded to make a field map of the location of the alleged site.

\section{Conclusions/ \\ Recommendations}

Site 41FT471, which may best be described as an isolated find, is a possible prehistoric site of unknown age. Given the shallow, eroded soils and apparently low artifact density, 41FT471 has low research potential and is classified as a Level 3 site (Moderate to Low Management Priority). Although the site's eligibility for NRHP nomination or SAL designation is unknown, CAS recommends that the $\mathrm{THC}$ be allowed to comment on any work that might be necessary.

\section{FT472}

Near the northeast corner of the park, 41FT472 is located on the edge of a northwesterlytrending ridge top. The ridge slopes significantly towards Fairfield Lake north of the parking lot that marks the site (Figure 4-35 and Figure 4-36). The parking lot is provided to park patrons who are using the boat ramp at the north end of the road. Wooded portions of the site consist of a mixture of hardwoods and cedar, including three large

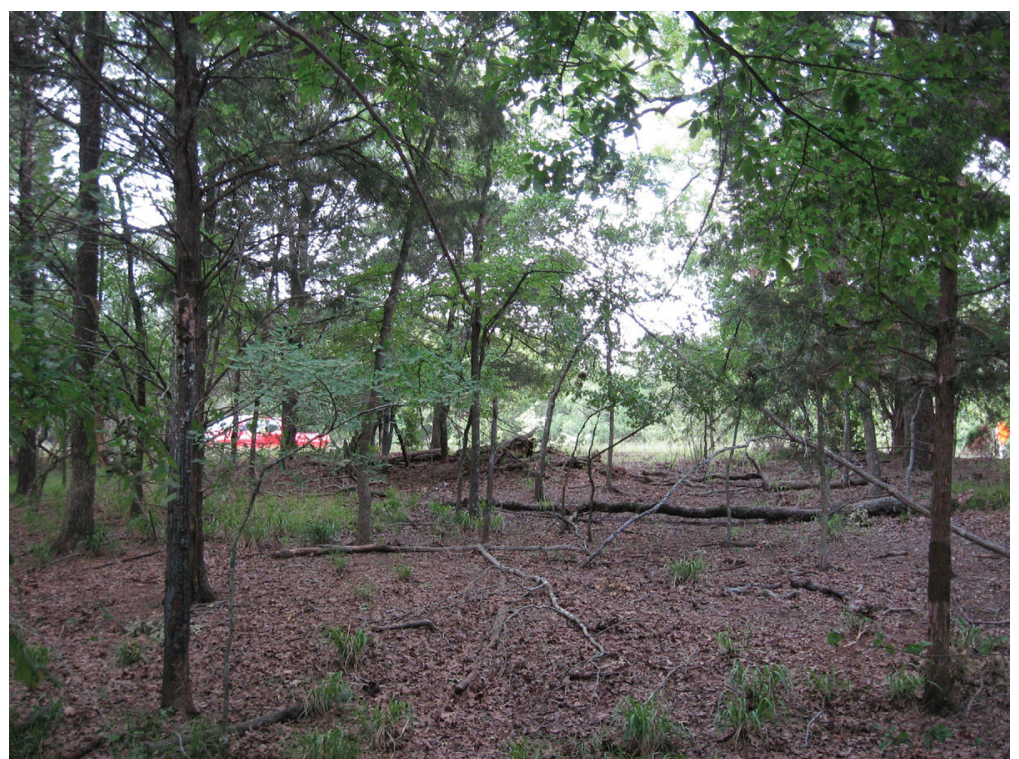

Figure 4-35. Overview of 41FT472; photographed facing south.
FIGURE 4-36. REDACTED

Figure 4-36. 41FT472 site map. 
Delineated by the extent of surficial artifacts and shovel tests containing cultural material, 41FT472's boundary measures approximately 40-m (N/S)-x-45-m (E/W).

\section{Level of Effort and Results}

Site 41FT472 was discovered and shovel tested were excavated by the SFA crew in 1996. A total of 11 shovel tests, two of which contained cultural material, were excavated at that time. One shovel test contained a possible flake made of silicified wood, and the other shovel test contained two possible flakes of silicified wood and a clear bottle glass sherd. In addition to cultural material recovered from subsurface tests, many artifacts were recovered from the surface. Surficial artifacts include three interior silicified wood flakes, a cut nail, a porcelain doll limb, four exterior quartzite flakes, three exterior chert flakes, nine interior chert flakes, a battered chert cobble, eight plain earthenware sherds, a piece of sandy mortar, a stoneware base sherd, a piece of flat glass, a stoneware sherd with Bristol glaze, a brown bottle glass sherd, two dark-olive bottle glass sherds, two aqua vessel glass sherds, a clear vessel glass sherd with evidence of burning, a silicified wood uniface, a quartzite cobble, and a ferruginous sandstone metate. Artifacts from the surface were recovered from two, separate concentrations, one east of the road and the other west of the road. Field records do not specify which artifacts came from which particular concentration.

When CAS archaeologists revisited the site in 2008, there were no longer dense concentrations of artifacts visible on the surface; a nineteenth century bottle fragment (dark olive/black) was observed and collected, and a few sherds of whiteware were only observed. CAS archaeologists excavated two shovel tests to investigate subsurface deposits and delineate the site's northern boundary. Both shovel tests were located in a wooded area on the northerly slope towards the river. Subsoil was encountered in ST 1 and 2 within $10 \mathrm{cmbs}$, and no cultural material was observed. In some areas on the slope, subsoil was visible at the surface. The majority of the site appears to have been disturbed by the construction of the parking lot and road leading down to the boat ramp (Figure 4-37).

\section{Conclusions/Recommendations}

Site 41FT472 has both prehistoric and historic components. Lithic artifacts, presumably prehistoric, are temporally non-diagnostic, and historic artifacts date from the late-nineteenth to early-twentieth century. Due to the amount of modern development, 41FT472 is classified as a Level 4 site (Low Management Priority) and is considered ineligible for NRHP nomination and SAL designation.

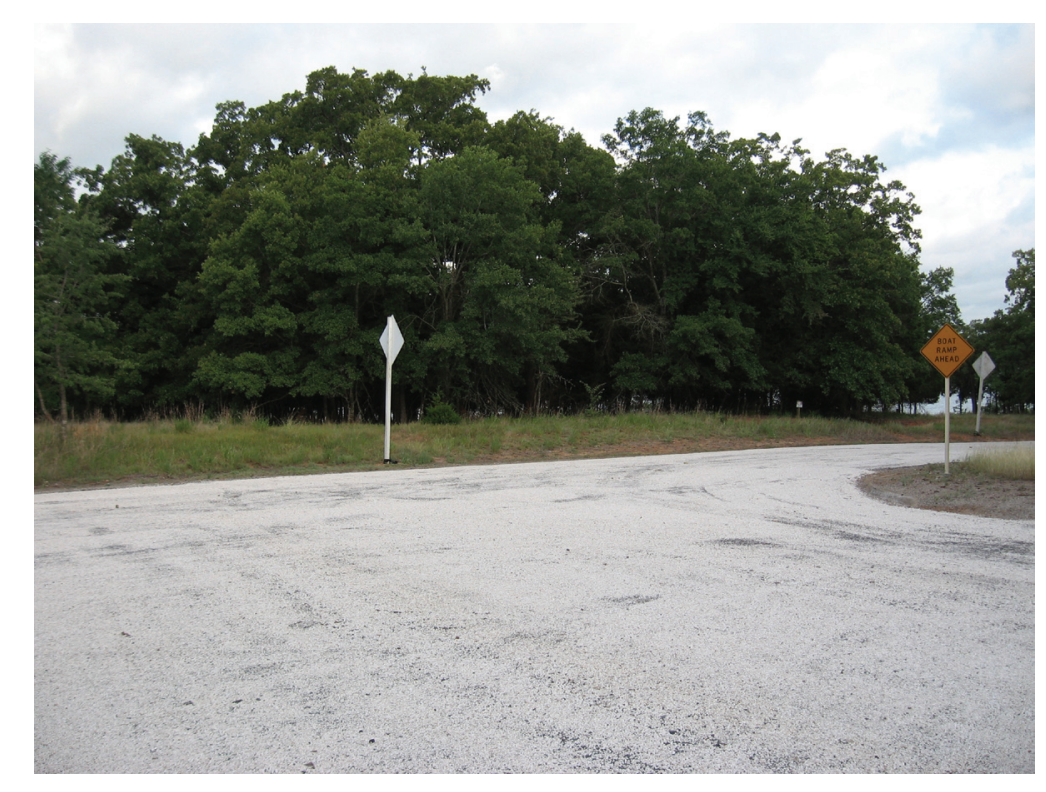

Figure 4-37. Overview of parking lot and boat ramp access road; photographed facing northwest. 


\section{FT473}

Site 41FT473 is a prehistoric lithic scatter situated on a low rise above a branch of Little Brown Creek and between the bases of a bifurcated ridge. The site is located in a small clearing (Figure 4-38). Vegetation in the area consists primarily of tall grasses/weeds and is supported by Nahatche-Hatliff (NH) association soils. As delineated by shovel tests, 41FT473 extends approximately $\quad 40-\mathrm{m} \quad$ (N/S)$\mathrm{x}-25-\mathrm{m}$ (E/W) (Figure 4-39). A historic dump, 41FT469, is located approximately 60-m northwest of 41FT473.

\section{Level of Effort and Results}

In 1996, 41FT473 was discovered by the SFA crew. At that time, the crew excavated nine shovel tests, three of which contained cultural material. Recovered from the three positive shovel tests were two interior chert flakes, a possible flake made of silicified wood, an exterior chert flake, an exterior quartzite flake, and a chert core with evidence of burning. When SFA archaeologists revisited the site three months later, they recovered one piece of ferruginous sandstone firecracked rock from the surface.

When CAS revisited 41FT473 in 2008, there was a significant amount of feral hog rooting visible. One shovel test was excavated to investigate subsurface deposits and delineate the western boundary of the site. The single shovel test excavated in 2008

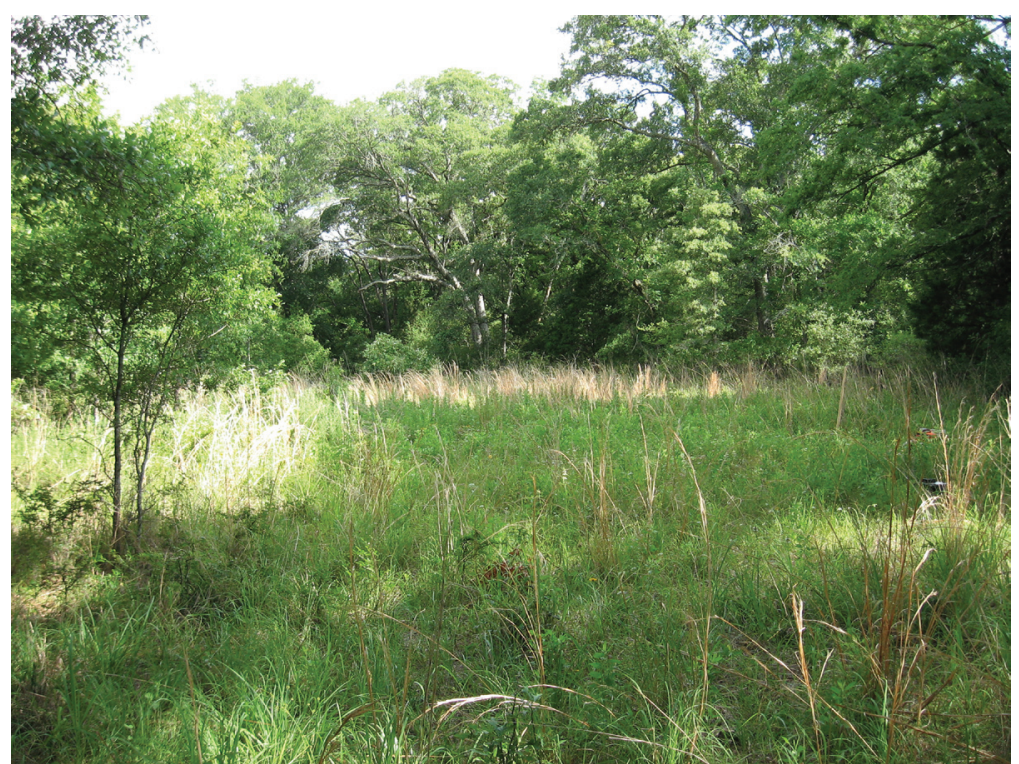

Figure 4-38. Overview of 41FT473; photographed facing northwest.

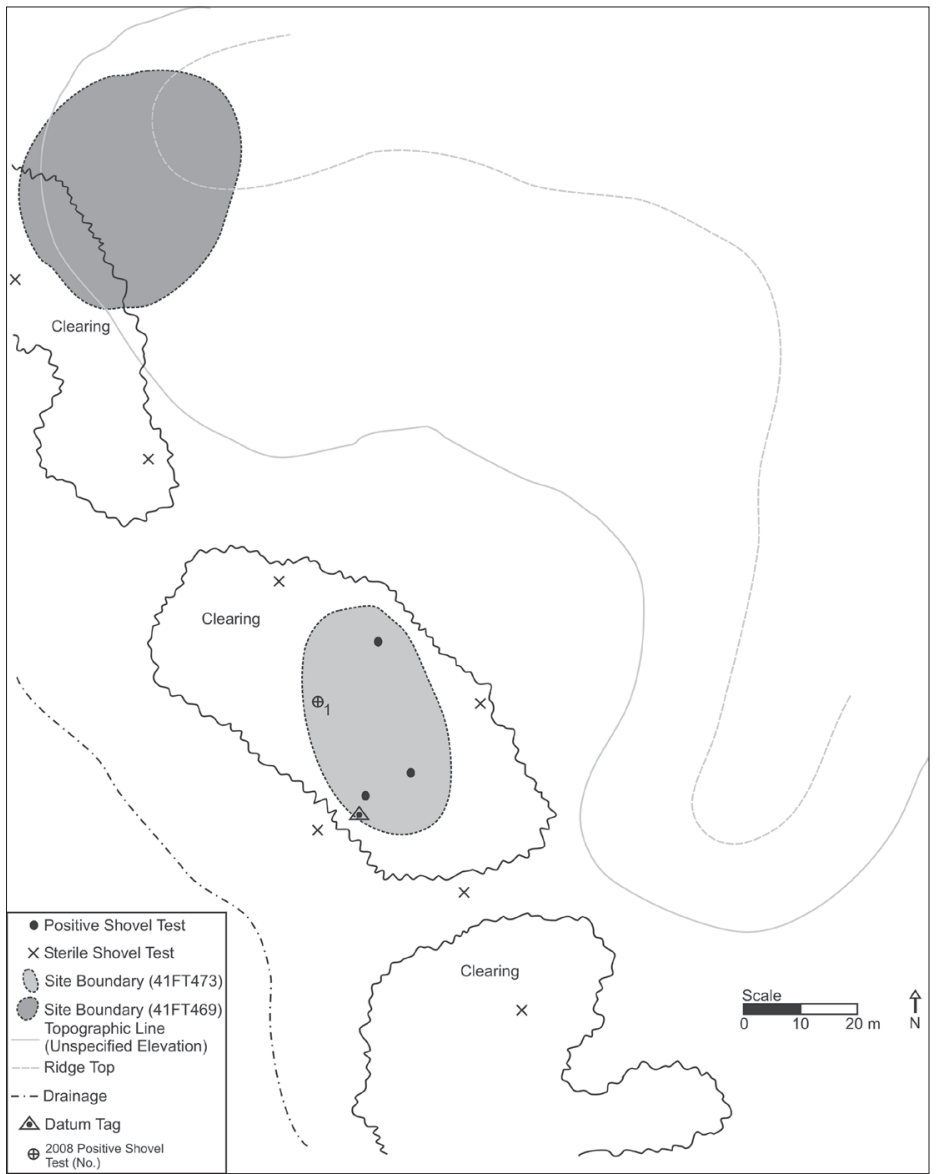

Figure 4-39. 41FT473 site map.

was located in the previously mentioned area of bioturbation, and it yielded one whiteware sherd 
$(0-20$ cmbs $)$. The sediments excavated were loamy sand and were probably alluvial/colluvial in origin. The subsoil, encountered at $34 \mathrm{cmbs}$, was mottled with grey suggesting that the area is seasonally wet or hydric. Due to the proximity to 41FT469 and to the amount of bioturbation, the whiteware sherd recovered from the shovel test was considered not to be in primary context.

\section{Conclusions/Recommendations}

Site 41FT473 is a prehistoric site of unknown age. Despite bioturbation, the presence of a historic artifact, and the small size of the site, 41FT473 is classified as a Level 2 site (Moderate to High Management Priority) due to the paucity of prehistoric sites in the area. Site 41FT473 appears to have good research potential. Without further work, the site's eligibility for NRHP nomination or SAL designation is unknown. Further eligibility testing will be necessary if future projects will impact the site.

\section{FT474}

Occupying the base of a low, narrow ridge approximately 100 $m$ south of the confluence of two tributaries of Little Brown Creek, $41 \mathrm{FT} 474$ is a historic site and probably represents the location of an alcohol still. The site is located in a densely wooded area with a thick understory of shrubs, briar, and vines supported by Nahatche-Hatliff $(\mathrm{NH})$ association soils and Edge fine sandy loam (EgE) (Figure 4-40). Site 41FT474's boundary is delineated by the extent of cultural material present on the surface. The site measures approximately 20-m (N/S)-x-20$\mathrm{m}(\mathrm{E} / \mathrm{W})$ (Figure 4-41).

\section{Level of Effort and Results}

The SFA crew discovered 41FT474 in 1996, and excavated four shovel tests in the vicinity of the concentrated surficial artifacts and features. All four shovel tests were devoid of cultural material. On the surface, the SFA crew observed pieces of sheet metal, barrel hoops, a 50-gallon metal drum, a sherd of glass with evidence of burning, and a depression approximately five meters in diameter. No cultural material was collected by the SFA crew. When CAS archaeologists revisited 41FT474 in 2008, barrel hoops, glass sherds, and the depression were still present. The depression is circular in shape, measures approximately 4.5 $\mathrm{m}$ in diameter, and is $60-80-\mathrm{cm}$ deep (Figure 4-42). One bottle glass base sherd with a HazelAtlas maker's mark, dating to ca. 1920-64, was collected from the surface at the site (Toulouse 1971). CAS archaeologists did not observe sheet metal or the 50-gallon metal drum that the SFA crew recorded, though the surface visibility was very low in 2008. CAS archaeologists determined that shovel tests were not necessary to confirm 41FT474's boundary.

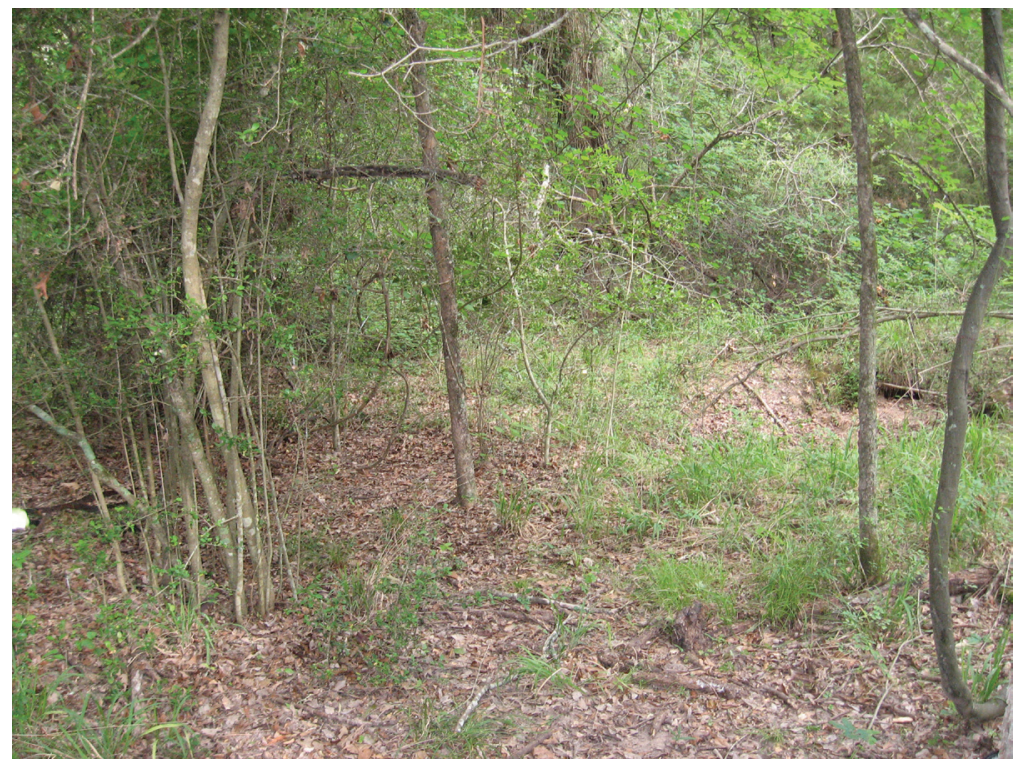

Figure 4-40. Overview of 41FT474 featuring miscellaneous metal (far left center) and a depression (far right center); photographed facing east. 


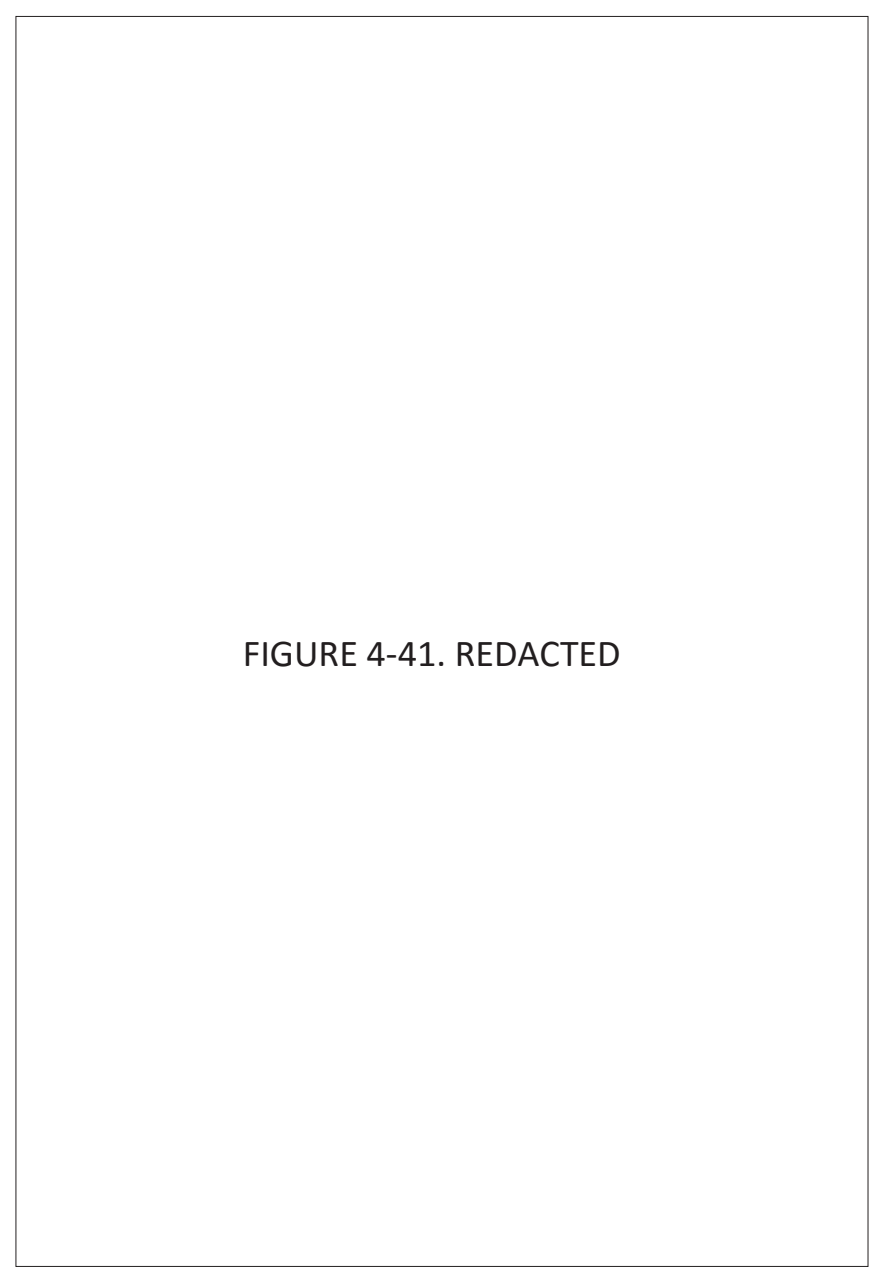

Figure 4-41. 41FT474 site map.

\section{Conclusions/Recommendations}

The artifacts present at 41FT474 and the history of Freestone County as a prominent producer of bootlegged liquor during Prohibition suggests that this site is, in fact, the location of an old still. The site appears to be intact and to have good research potential, and it is therefore classified as Level 2 (Moderate to High Management Priority). In the event that this site is threatened by future developments, CAS recommends additional work to confirm the date of this site and to determine the site's eligibility for NRHP nomination or SAL designation. Without additional investigations, the site's eligibility for NRHP nomination or SAL designation is unknown.

\section{FT475}

Site 41FT475 is located on the northern slope of a north-south trending ridge overlooking Fairfield Lake. The landform is wooded with various hardwoods, mostly oak, and has a thin, grassy understory supported by Edge fine sandy loam (EgE) (Figure 4-43). Site 41FT475 consists of a scatter of historic debris measuring approximately $20-\mathrm{m}$ (N/S)-x-45-m (E/W) (Figure 444). The site is bisected by theroad that provides access to the point of the park's central peninsula at the former confluence of Big Brown Creek and Little Brown Creek. A recently buried cable on the west side of the road has also impacted a portion of the site.

Figure 4-42. Depression at 41FT474; photographed facing southeast. 


\section{Level of Effort and Results}

In 1996, the SFA field crew discovered the scatter of historic debris that composes 41FT475. They observed, but did not collect, bottle glass sherds, barrel hoops, a portion of a propeller, stoneware, white earthenware, machine-made bricks with "Mexia" stamps, bucket fragments, barbed wire, and a large piece of metal equipment that was possibly once part of a plow. The SFA crew excavated one shovel test two meters west of the paved park

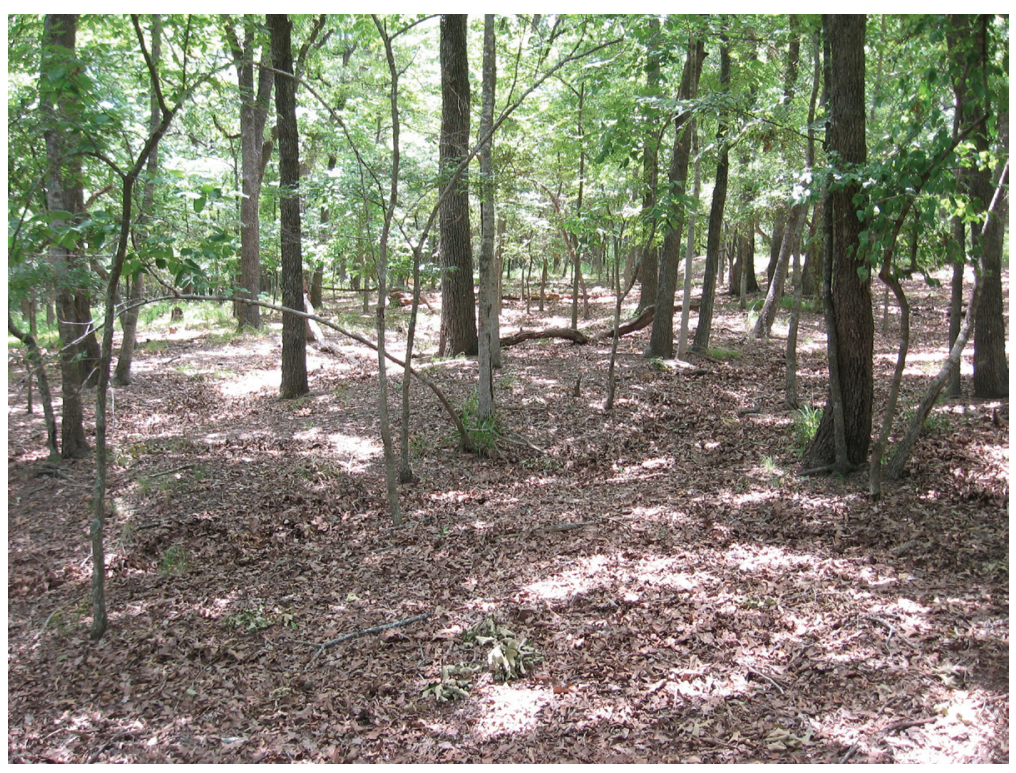

Figure 4-43. Overview of 41FT475; photographed facing southeast. road and another shovel test two meters east of the road. Both shovel tests were devoid of cultural material. In 2008 when CAS archaeologists revisited the site, one shovel test was excavated in the center of the scatter to the east side of the road (approximately 18-m east of the road). ST 1 was devoid of cultural material and encountered subsoil at $15 \mathrm{cmbs}$. The slope of the ridge that the site occupies is heavily eroded and marked by rainwater runoff gullies. Artifacts observed but not collected by CAS archaeologists on the east side of the road include machine-made "Mexia" brick, stoneware, solarized glass sherds, brown bottle glass, a fragment of a boat propeller, and other miscellaneous metal objects (Figure 4-45 and Figure 4-46).

CAS archaeologists also observed, to the southeast of the site, a possible historic road cut. This feature on the landscape may have connected to the historic road cut east of site 41FT466, but this association was not clearly discernible. On the west side of the park road, only a few sherds of whiteware were observed on the surface, but they were associated with

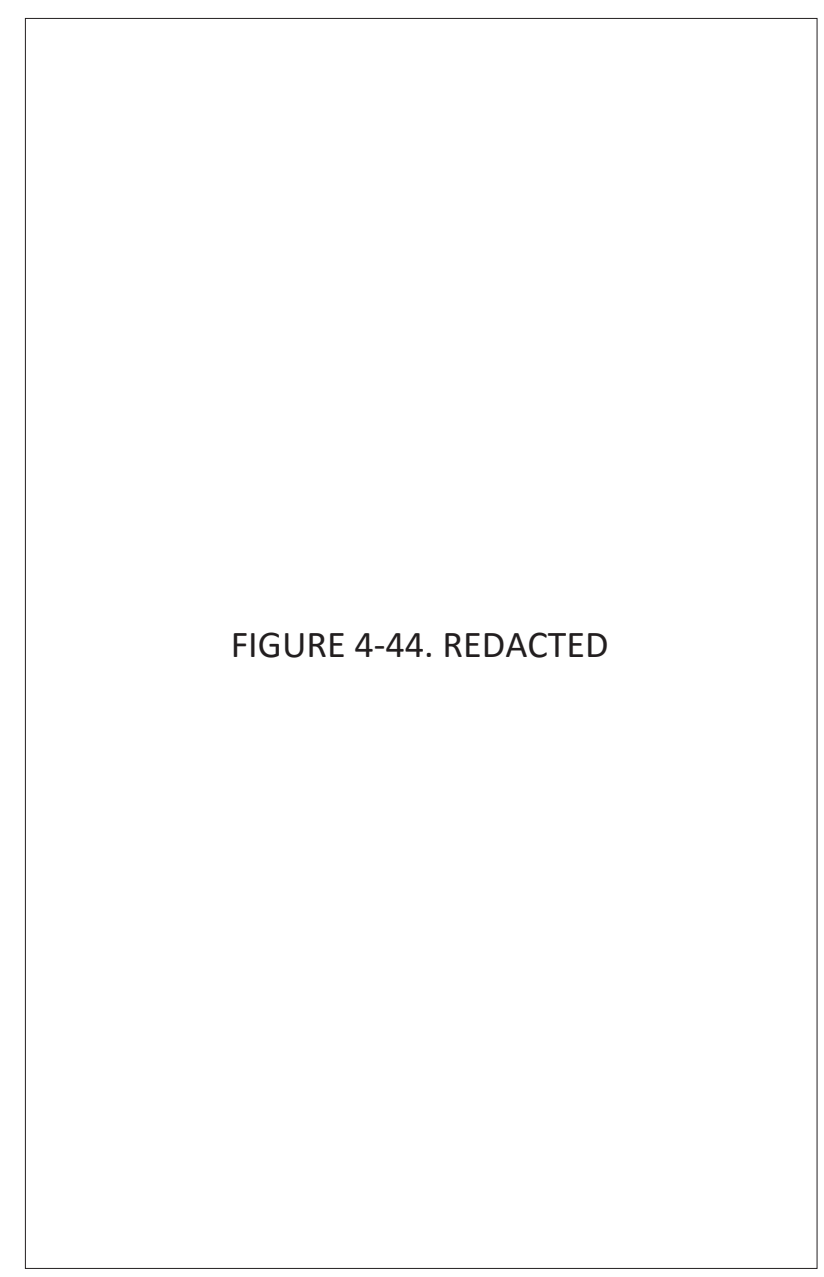

Figure 4-44. 41FT475 site map. 


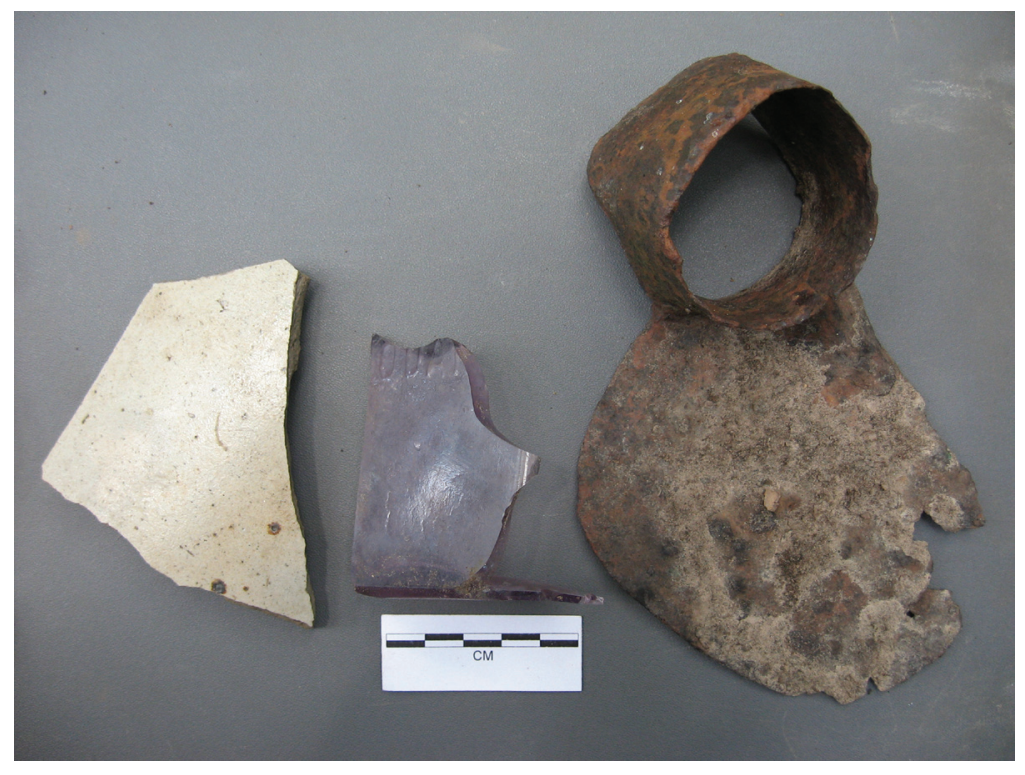

Figure 4-45. Artifacts observed on the surface at 41FT475.

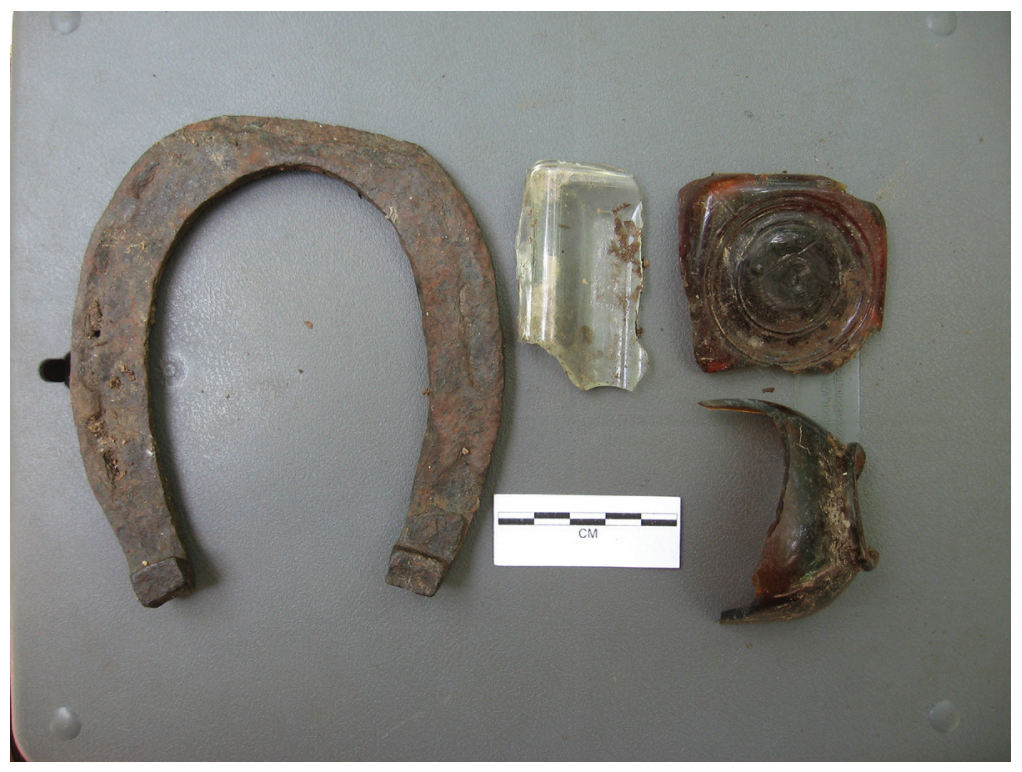

Figure 4-46. Artifacts observed on the surface at 41FT475.

the trench that had recently been excavated and filled in order to bury a high voltage cable.

\section{Conclusions/Recommendations}

As a deflated and disturbed historic dump, 41FT475 is classified as a Level 3 site (Moderate to Low ManagementPriority). Further investigations into the possible association between 41FT475 and 41FT466 could increase 41FT475's currently low research potential. Although the site's eligibility for NRHP nomination or SAL designation is unknown, CAS recommends that the THC be allowed to comment on any work that might be necessary.

\section{FT476}

Site 41FT476 is a prehistoric lithic scatter located on a low ridge spur overlooking a small, intermittent drainage in the southern portion of the park. The vegetation on this landform, supported by Silstid loamy fine sand $(\mathrm{SsB})$, consists of a grassy clearing and a wooded area composed of mature oaks and a thick understory of vines and shrubs near the drainage (Figure 4-47). The boundaries of 41 FT476 are defined by a road to the east, a drainage to the south, and sterile shovel tests to the west and north; the site measures approximately $15-\mathrm{m}(\mathrm{NE} / \mathrm{SW})$-x35-m (NW/SE) (Figure 4-48).

\section{Level of Effort and Results}

The SFA crew discovered 41FT476 in 1996. At that time, a total of 12 shovel tests were excavated, and three of them contained cultural material. Cultural material collected from the three positive shovel tests included an interior sandstone flake, a quartzite flake, and a sherd of clear, water-worn flat glass $3.03 \mathrm{~mm}$ thick. The hydric ware on the sherd of flat glass suggests the possibility that it was translocated by the drainage adjacent to the site during a heavy rainfall event. In addition to the material recovered from the 
subsurface tests, one piece of ferruginous sandstone firecracked rock was recovered from the surface.

In 2008, CAS archaeologists revisited 41FT476. Between the extensive shovel testing performed by the SFA crew, the drainage adjacent to the south of the site, and the road adjacent to the east, the site was well-defined and no further shovel testing was determined to be necessary by CAS archaeologists.

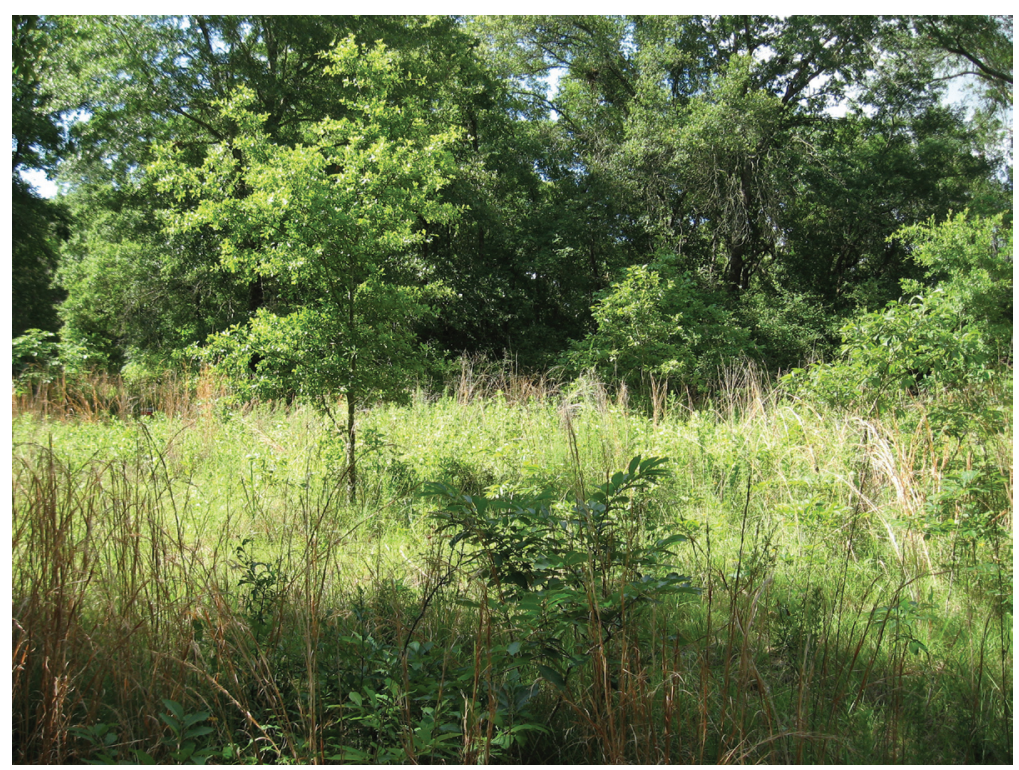

Figure 4-47. Overview of 41FT476; photographed facing south.

\section{Conclusions/ \\ Recommendations}

Site $41 \mathrm{FT} 476$ is a prehistoric lithic scatter of unknown age. Given its small size and apparently low artifact density, $41 \mathrm{FT} 476$ is classified as a Level 3 site (Moderate to Low Management Priority) and appears to have low research potential. Although the site's eligibility for NRHP nomination or SAL designation is unknown, CAS recommends that the THC be allowed to comment on any work that might be necessary.

\section{FT477}

Site $41 \mathrm{FT} 477$ is a scatter of historic debris located on the gentle northwestern slope of a relatively narrow ridge spur near the confluence of a small, dry
FIGURE 4-48. REDACTED

Figure 4-48. 41FT476 site map.

tributary of Ball Branch and Fairfield Lake. The vegetation at the site is heavily overgrown with vines, briars, and shrubs supported by Edge 
fine loamy sand (EgE) (Figure 4-49). Ornamental plants were noted by the SFA crew and are still present at the northern edge of the site. Site 41FT477 is delineated to the north, east, and west by the confluence of the lake and intermittent drainage, and to the south by a sterile shovel test excavated by the SFA crew in 1996. The site measures approximately 125-m (N/S)-x55-m (E/W) (Figure 4-50).

\section{Level of Effort and Results}

In 1996, the SFA crew discovered site 41FT477 and excavated 10 shovel tests on the narrow ridge spur. Eight of the shovel tests yielded cultural material, including a brown bottle glass sherd, a fence staple, two wire nails, six clear vessel glass sherds, three milk glass mason jar lid fragments, an earthenware body sherd with repousse, two plain earthenware body sherds, two pieces of plastic, two cut nails, two modern vessel glass sherds, two wire tacks, a burned bone fragment, a screwon metal lid, a metal button with a star design, eight metal lid fragments, and three pieces of miscellaneous metal. All of the above-listed artifacts were collected for curation. In addition to the artifacts recovered from subsurface testing, a pile of bricks was observed on the surface just south of the ornamental plants at the north end of the site.

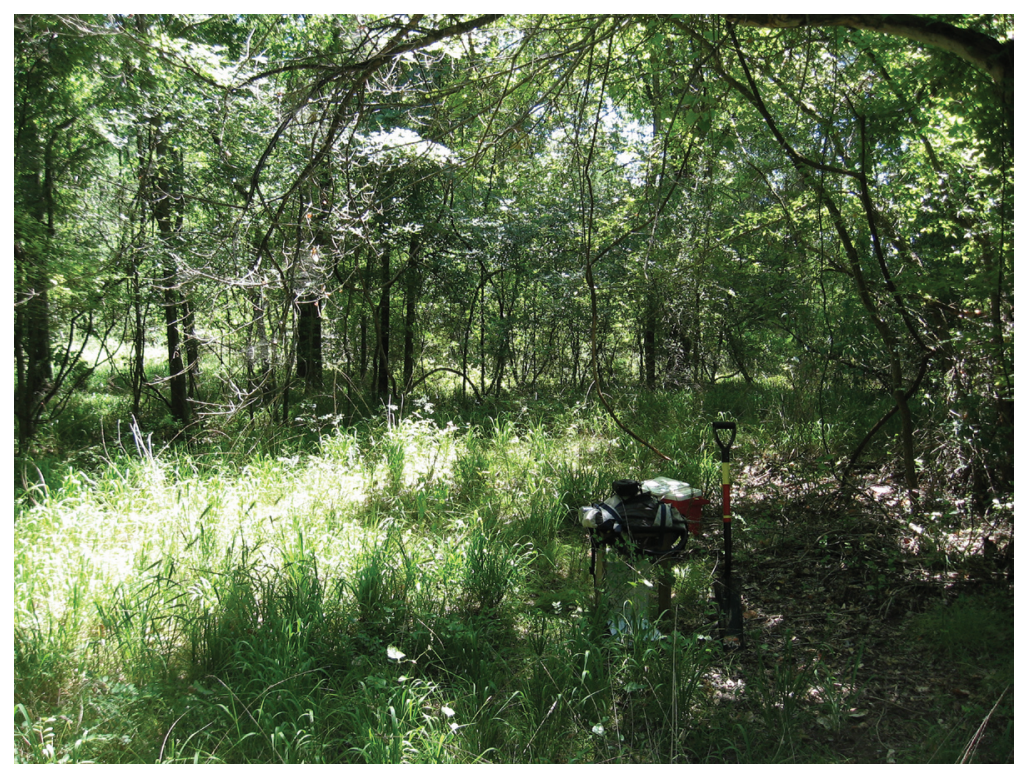

Figure 4-49. Overview of 41FT477; photographed facing southeast.

FIGURE 4-50. REDACTED

Figure 4-50. 41FT477 site map. 
In 2008, CAS archaeologists revisited site 41FT477. The cluster of ornamental plants and the pile of bricks were still present and visible on the surface. The pile of bricks is composed of low-fired bricks and is partially submerged under vegetation and soil. The ornamental plants have rhizomes, but identification of the specific plant is uncertain without flowers. Artifacts observed in the drainage to the east of the site included solarized glass, miscellaneous metal fragments, and one complete bottle were. The collected complete bottle has an Owens-Illinois maker's mark dating to ca. 1924-54 (Toulouse 1971). No shovel tests were excavated by CAS archaeologists as the site's boundaries were adequately defined by shovel testing in 1996.

\section{Conclusions/Recommendations}

Site 41FT477 is an early-twentieth century historic scatter and possibly marks the location of a historic structure. An unusually thick understory prohibited thorough assessment of the site, but it appears that intact cultural deposits are present. Site 41FT477 has good research potential and is classified as a Level 2 site (Moderate to High Management Priority). Currently, the site's eligibility for NRHP nomination or SAL designation is unknown. In the case that the site will be affected by future impact, further testing would be necessary to delineate precise site boundaries and to investigate the site's eligibility for NRHP nomination and SAL designation.

\section{FT478}

Located on a broad, lobed, easterly-trending ridge overlooking Little Brown Creek to the north is a prehistoric lithic scatter, 41FT478. The site occupies a clearing with moderately thick grass, weeds, and shrubs supported by Silstid fine sandy loam (SsB) (Figure 4-51). The general location of the site is marked by the intersection of the main park road and the road providing access to the maintenance barn, but the site size is undetermined (Figure 4-52). Just north of the site is a dry drainage bed which intersects with the maintenance barn access road.

\section{Level of Efforts and Results}

In 1996, the SFA crew excavated nine shovel tests in the clearing on the broad, lobed ridge. One of the shovel tests, located near the center of the clearing, contained cultural material. An interior chert flake was the only artifact recovered from the single, positive shovel test. In 2008, CAS archaeologists revisited 41FT478. In order to delineate the northern extent of the site and to investigate subsurface deposits, CAS archaeologists excavated one shovel test approximately $10-\mathrm{m}$ north of the approximate location of the positive shovel test excavated in 1996. The shovel test excavated in 2008 was devoid of cultural material. The sediment excavated was gravelly, loamy sand, and clayey subsoil was encountered at 19 cmbs.

\section{Conclusions/Recommendations}

Given the small size and low artifact density, 41FT478 is considered to be an isolated find and is classified as a Level 3 site (Moderate to Low Management Priority) with low research potential. Although the site's eligibility for NRHP nomination or SAL designation is unknown, CAS recommends that the THC be allowed to comment on any work that might be necessary.

\section{FT479}

Site $41 F T 479$ is a prehistoric lithic scatter located on a slight rise on the eastern edge of a wide, flat, southerly-trending ridge overlooking Little Brown Creek. Modern development in the vicinity of the site includes a fence marking a portion of the park's southern boundary, a trail which follows the park's boundary, and a 


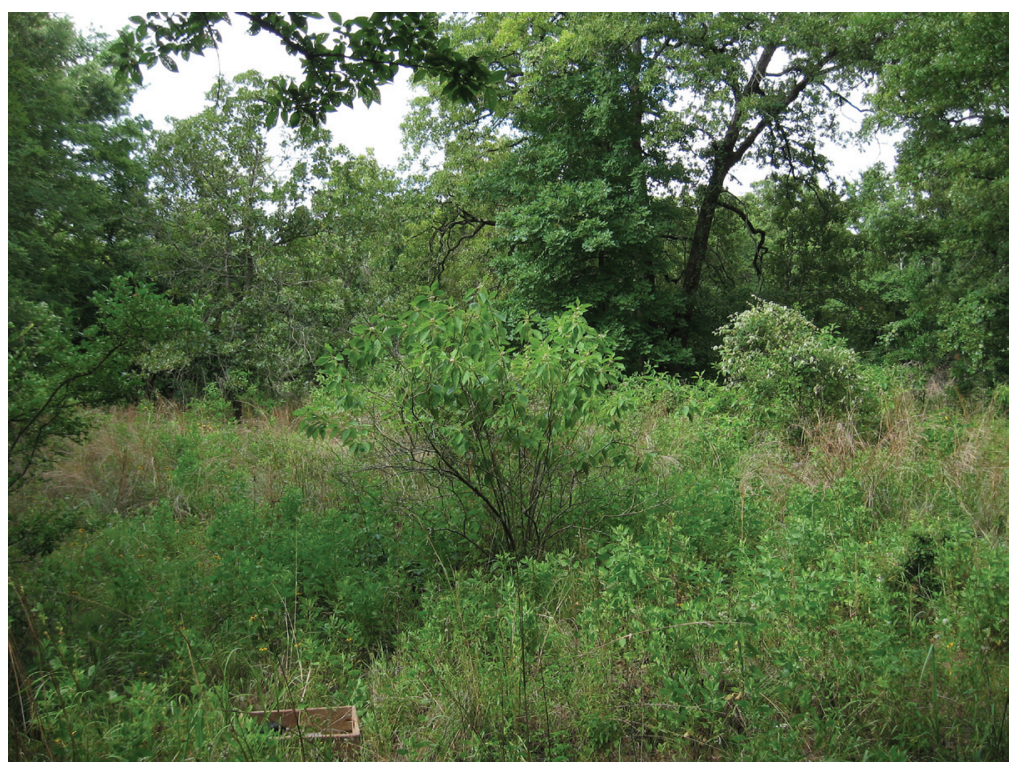

Figure 4-51. Overview of 41FT478; photographed facing southeast.

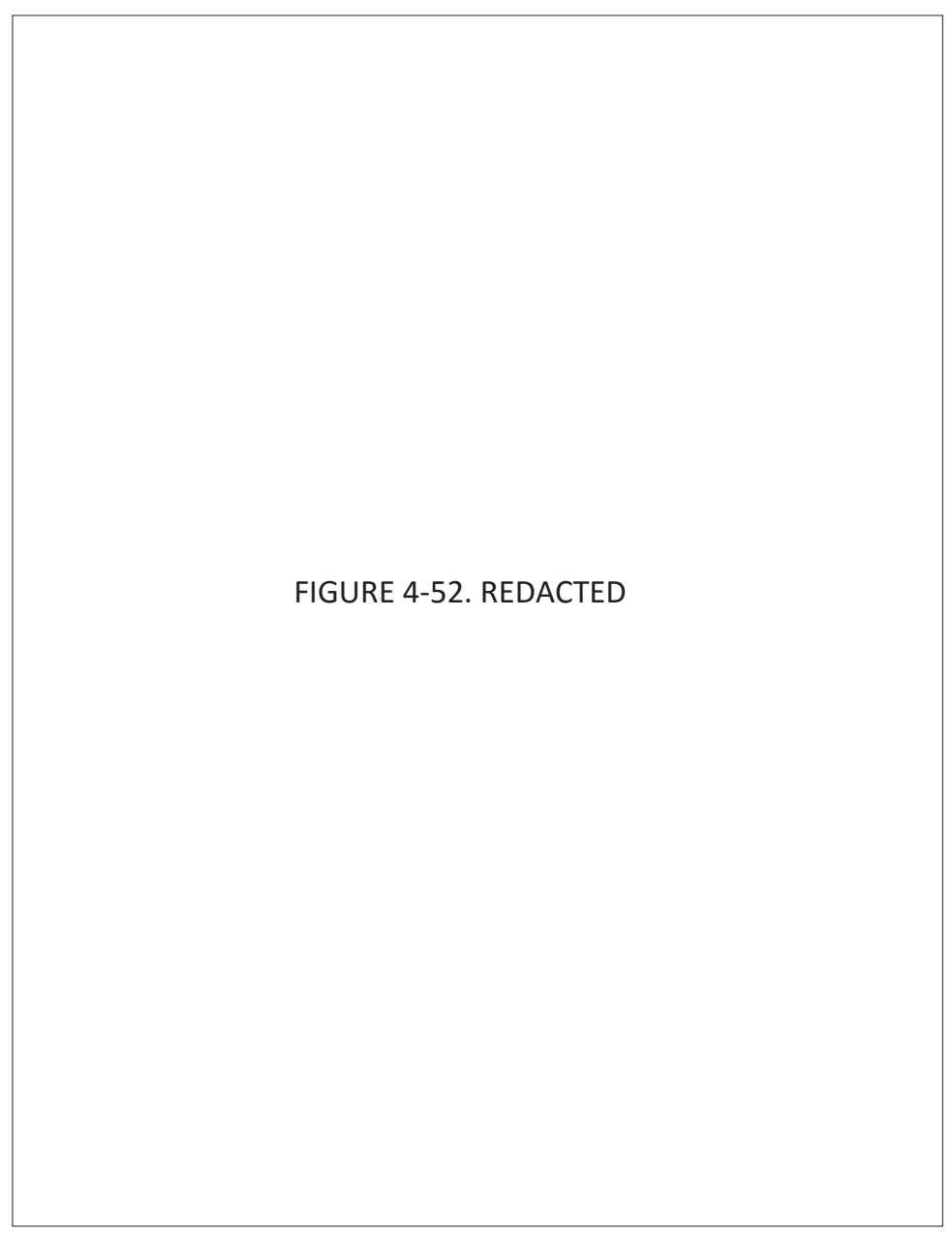

Figure 4-52. 41FT478 site map. paved, park road approximately $30 \mathrm{~m}$ to the east. Vegetation on this landform includes mixed hardwoods (primarily oak and hickory) and a thick understory of weeds and shrubs supported by Silstid loamy fine sand (SsD) (Figure 4-53). The extent of the site beyond the park's boundary is undetermined. Within the park, the site measures approximately 40-m (N/S)-x-12-m (E/W) (Figure 4-54).

\section{Level of Effort and Results}

In 1996 when the SFA crew surveyed the park, it appears that they shovel tested the top of this wide, flat, southerly-trending ridge along the park boundary trail. Five shovel tests were excavated, and two of them contained cultural material. An interior chert flake was found in each shovel test.

CAS archaeologists revisited 41FT479 in 2008. To investigate the site's eastern boundary and subsurface deposits, one shovel test was excavated approximately $15-\mathrm{m}$ east of the fence line at the center of the site. No cultural material was observed in this shovel test, but the excavation did reveal that the sediments are moderately deep. Subsoil was encountered at 57 cmbs. Accordingly, amendments to the site boundary were made by CAS archaeologists. 


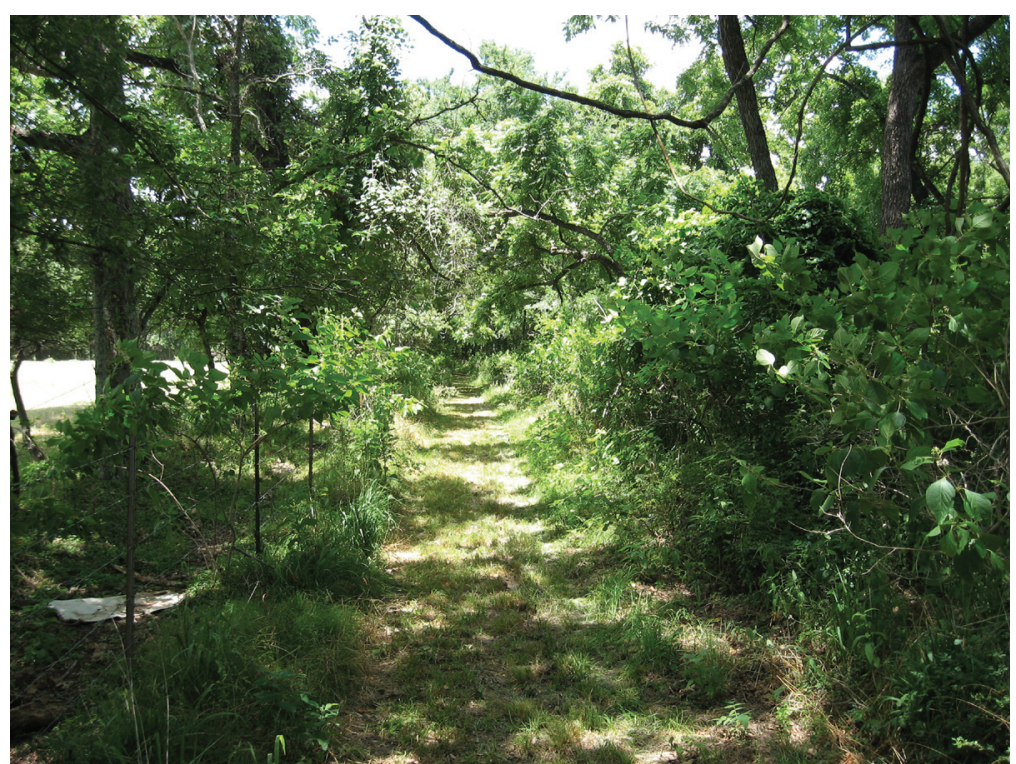

Figure 4-53. Overview of 41FT479; photographed facing south.

\section{Conclusions/ Recommendations}

Site 41FT479 is a small prehistoric lithic scatter with low artifact density. Both the private land adjacent to the park and the park land itself have been modified, and only a small portion of this site probably remains intact. As such, 41FT479 has low research potential and has been classified as a Level 3 site (Moderate to Low Management Priority). Although the site's eligibility for NRHP nomination or SAL designation is unknown, CAS recommends that the THC be allowed to comment on any work that might be necessary.

\section{FT480}

Site 41 FT480 is a prehistoric lithic scatter located on the crest of a somewhat narrow ridge on the west side of the park. The site occupies a heavily wooded area with a mix of hardwoods of varying age; the understory is relatively thick and consists of young trees, shrubs, and grass (Figure 4-55). Soil in the area of the site is mapped as Edge fine sandy loam (EgE). Delineated by shovel tests, 41FT480 measures approximately 10-m (N/S)-x-15$\mathrm{m}(\mathrm{E} / \mathrm{W})$ (Figure 4-56).

\section{Level of Effort and Results}

The SFA crew discovered 41FT480 in 1996. At that time, they excavated 14 shovel tests on the crest of this narrow ridge. Two of the shovel tests contained cultural material. From one shovel test, the SFA crew recovered an interior quartzite 
flake and two worked/modified quartzite cobbles. One interior quartzite flake was recovered from the other positive shovel test. The two positive shovel tests were located within five meters of one another and just to the southwest of the top of the ridge crest. The other 12 shovel tests excavated in 1996 surrounded the two positives shovel tests, effectively delineating the site. CAS archaeologists revisited the site in 2008 and determined that further shovel testing was unnecessary. Leaf litter and patchy grass obscured the ground

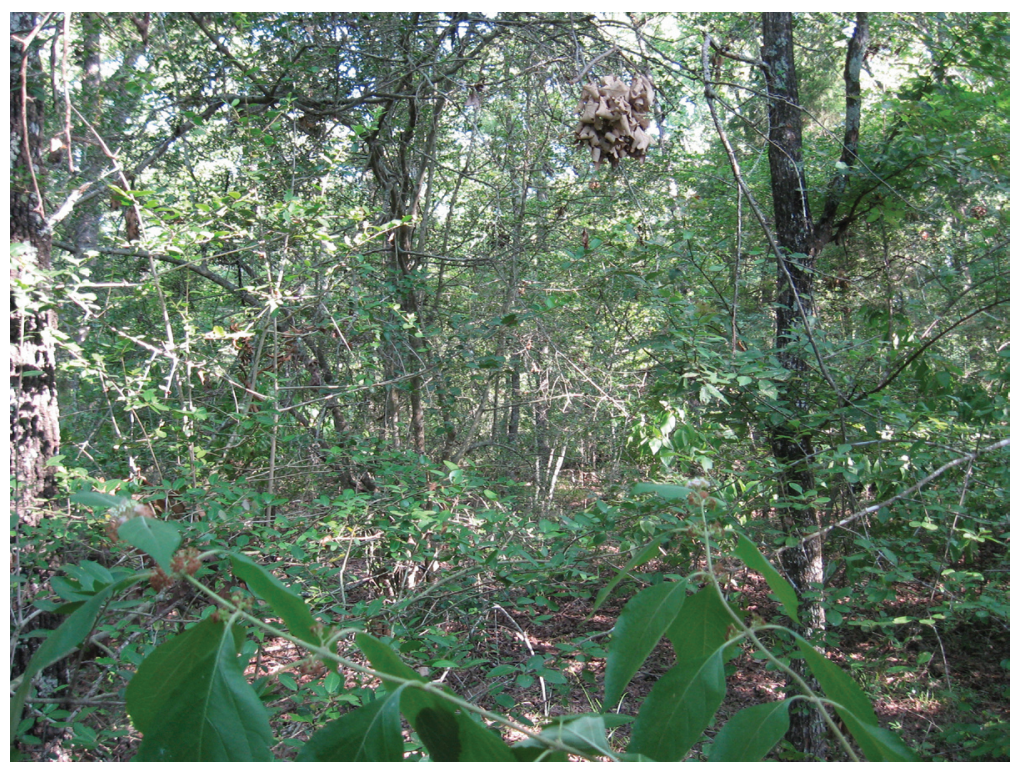

Figure 4-55. Overview of 41FT480 featuring thick vegetation; photographed facing west.

surface (less than five percent surface visibility), and no cultural material was observed.

\section{Conclusions/Recommendations}

Site 41FT480 is a small prehistoric lithic scatter with relatively low artifact density and low research potential. Accordingly, 41FT480 is classified as a Level 3 site (Moderate to Low Management Priority). Although the site's eligibility for NRHP nomination or SAL designation is unknown, CAS recommends that the THC be allowed to comment on any work that might be necessary.

\section{FT481}

Located in a grassy clearing on a wide, relatively flat ridge that slopes gently to the northwest, 41FT481 is a scatter of historic debris and possibly marks the former location of a historic structure. Supported by Edge fine loamy sand $(\mathrm{EgE})$, the vegetation consists FIGURE 4-56. REDACTED

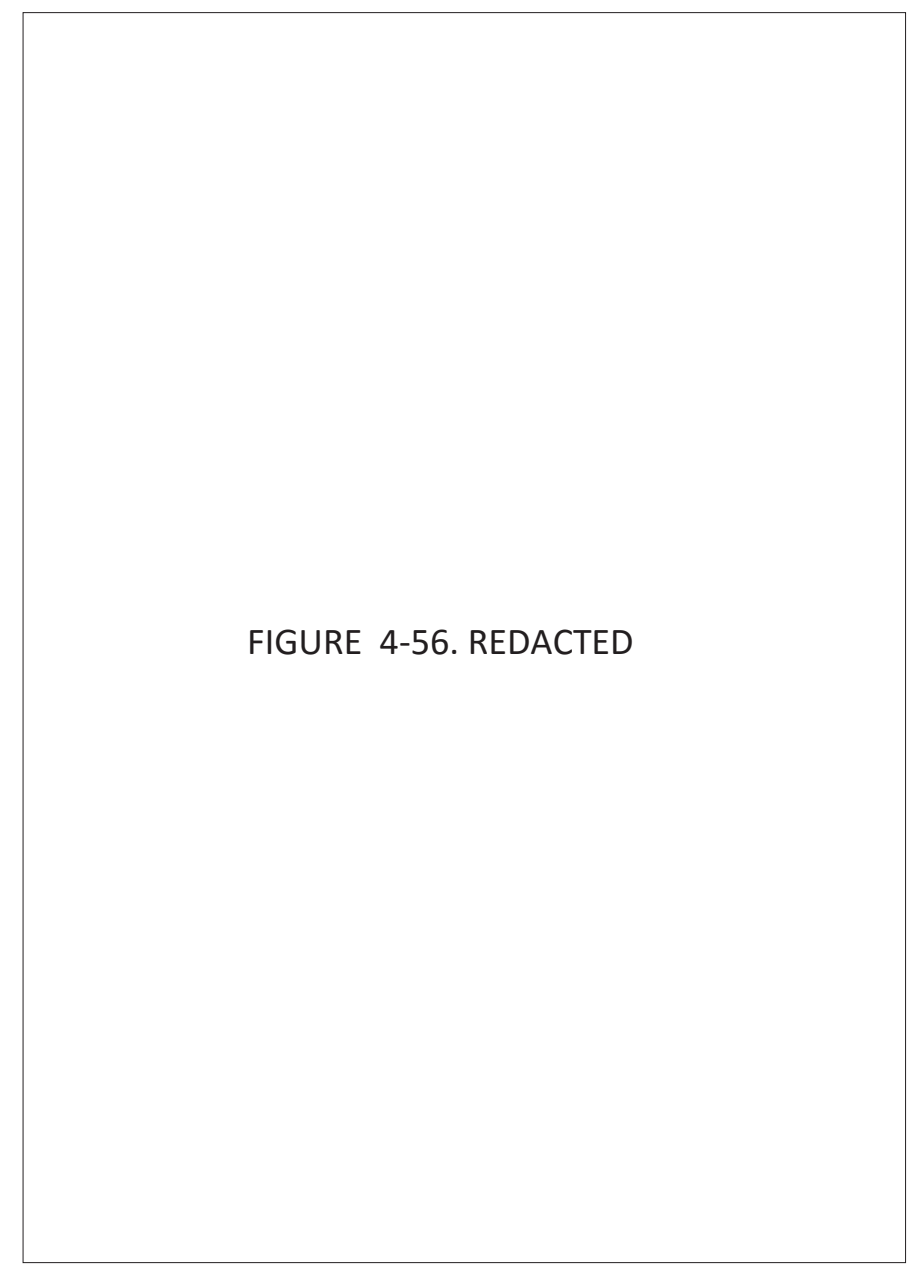

Figure 4-56. 41FT480 site map. 
primarily of thick grasses and mixed hardwoods of varying age (Figure 4-57). Site 41FT480's boundary is defined by shovel tests to the north, east, and west, and to the south by the extent of the surficial historic scatter. As observed by the SFA crew, a dry, heavily eroded drainage to the southwest of the site was once the location of a concentration of historic debris considered to be a dump, but due to the work of park personnel or heavy rainfall events, the drainage is nearly void of cultural material and is not included in the site boundary. Site 41FT481 measures approximately $60-\mathrm{m}(\mathrm{N} / \mathrm{S})-\mathrm{x}-$ 50-m (E/W) (Figure 4-58).

\section{Level of Efforts and Results}

The SFA crew discovered 41FT481 in 1996. At that time, 10 shovel tests were excavated on the landform. Seven of the shovel tests contained cultural material, including a clear vessel glass sherd with evidence of burning, six pieces of miscellaneous metal, two low-fired brick fragments, a clear bottle glass sherd, two clear vessel glass sherds, a flat glass sherd (measuring $1.88 \mathrm{~mm}$ thick), and 10 brown bottle glass sherds. Cultural material from subsurface testing was collected for curation. In addition to the items collected from the seven shovel tests, cultural material was observed and collected from the surface. Material collected from the surface includes a clear bottle glass sherd, a brown bottle glass base sherd, a stoneware sherd with Albany slip, an earthenware rim sherd with flow blue, a green bottle glass base

FIGURE 4-58. REDACTED

Figure 4-58. 41FT481 site map. 
sherd, a metal strap fragment, a clear paneled and embossed bottle glass sherd, a cut nail, six plain earthenware sherds, an earthenware plate fragment with declamania and gold trim, and a low-fired brick fragment. It is not certain where the artifacts were recovered from on the surface. Cultural material was visible on the surface in a concentration near the shovel tests and also in the dry drainage where the purported historic dump was located. In any case, all of the artifacts collected by the SFA crew from this area are representative of a single site.

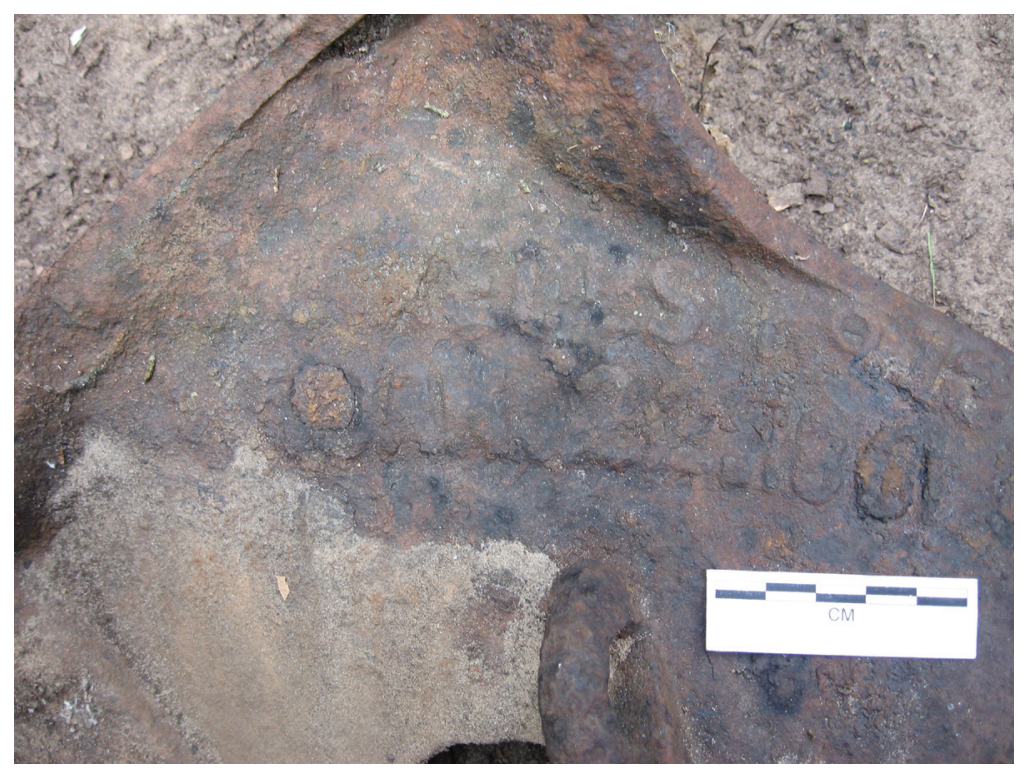

Figure 4-59. Fragment of a plow with raised letters.

Level 1 (High Management Priority). It is recommended as eligible for NRHP nomination

CAS archaeologists returned to 41FT481 in 2008. Cultural material was still present and visible on the surface in the clearing, but only a few pieces of miscellaneous metal and 1 whiteware sherd were observed in the drainage. Among the historic debris observed on the surface in the clearing were scattered low-fired brick fragments and a fragment of a plow with raised letters reading: "W(?)ELLS NO. 13, JAN 22, 1861" (Figure 4-59: IMG 60). CAS archaeologists confirmed 41FT481's boundary to the east by excavating a shovel test approximately $40-\mathrm{m}$ east of the datum. ST 1 was sterile, and subsoil was encountered at $30 \mathrm{cmbs}$. CAS archaeologists redefined the southern boundary of the site to include the entire range of the low-fired brick scatter.

\section{Conclusions/Recommendations}

Site 41FT481 is a historic site dating from the late-nineteenth century to early-twentieth century. Given the high density of artifacts, deposits that appear to be intact, and excellent research potential, 41FT481 is classified as or SAL designation. In the event that this site is threatened by future developments, CAS recommends additional shovel testing and archival research to confirm the date of this site and to offset the resulting loss of information.

\section{FT482}

Site 41FT482 is a large historic site located along the western edge of an irregularly shaped ridge in the eastern portion of the park. The ridge gently slopes west towards Fairfield Lake, and a dry, erosional gully skirts the southern boundary of the site. The paved access road to the Springfield Camping Area bisects 41FT482. The site occupies a wooded area and a clearing. The vegetation, supported by Edge fine sandy loam (EgE), ranges from mixed hardwoods with a light, grassy understory to thick, tall bunch grasses and weeds (Figure 4-60). Surface visibility varies from less than five percent to greater than 50 percent with vegetation. As delineated by shovel tests, an erosional gully, and the extent of surficial artifacts and features, 
41FT482 measuresapproximately 95-m (N/S)-x-95-m (E/W) (Figure 4-61).

\section{Level of Effort and Results}

In 1996, the SFA field crew discovered 41FT482. Initially, 41FT482 was delineated by shovel tests to the northeast and by the extent of surficial artifacts and features to the southwest; the site was limited to an area just north of the erosional gully. The SFA crew excavated a total of six shovel tests, all located north of Springfield Camping Area road, in the vicinity of the surficial scatter of artifacts. Three of the shovel tests contained cultural material, including 16 brick fragments, 14 of which were low fired, one with green lead glaze, and one with white salt glaze; all of the brick fragments were collected. From the surface on both sides of the road, the SFA crew collected a milk glass plate rim sherd, an earthenware base sherd with an unidentifiable portion of a maker's mark, an earthenware plain base sherd, a porcelain plain base sherd, a blue vessel glass rim sherd, a milk glass mason jar lid fragment, two

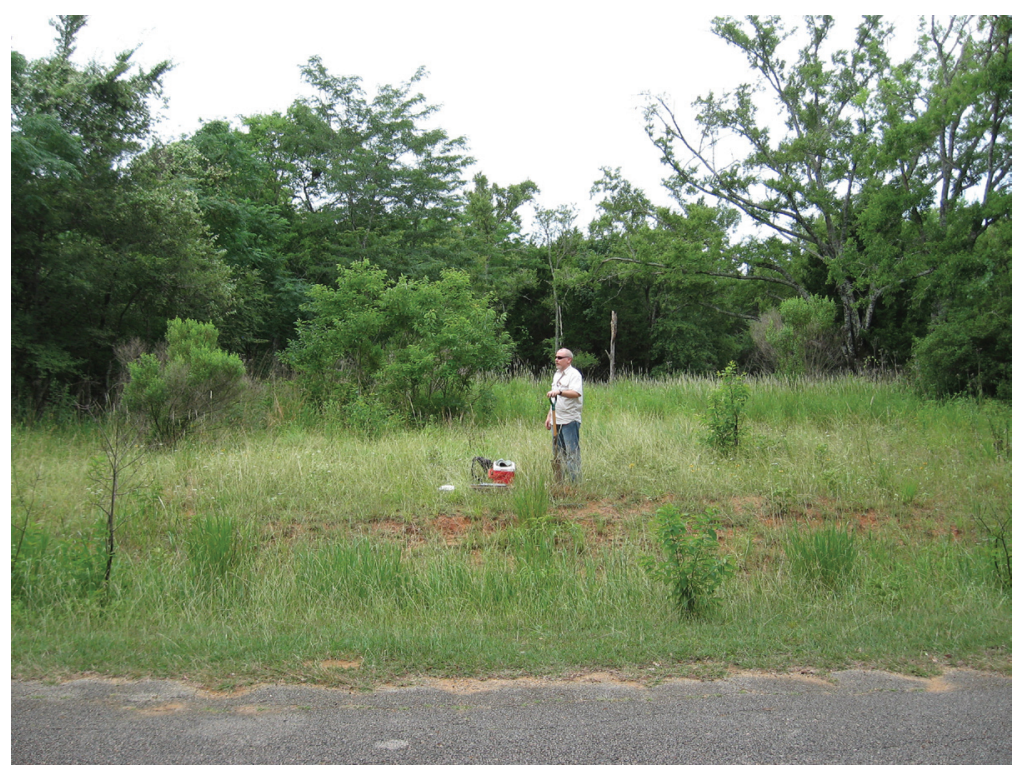

Figure 4-60. Overview of 41FT482 with Springfield Camping Area road in the foreground; photographed facing north.
FIGURE 4-61. REDACTED

Figure 4-61. 41FT482 site map. 
earthenware pitcher sherds with declamania and repousse, and an earthenware rim and base sherd with repousse and evidence of burning.

Other material observed but not collected by the SFA crew included tin cans, chicken wire, barbed wire, squared wire, metal hoops and miscellaneous tin fragments. The artifacts observed and/or collected by the SFA crew were distributed in piles which were probably the result of the road constructions and thus, not in primary context. Records from the SFA crew's initial survey also indicate that at the center of the site, on the south side of the road, there was a previously surveyed benchmark.

In 2008, CAS archaeologists returned to 41FT482. Artifacts, including miscellaneous tin, barbed wire, and low-fired brick, were still visible along the dry, erosional gully. A brown glass bottle with raised lettering reading "Clover's Imperial Medicine," produced by Whitall-Tatum Co. and dated to ca. 1935-38, was collected from the scatter of historic debris along the gully (Toulouse 1971) (Figure 4-62, Lot 5). One shovel test was excavated by CAS archaeologists in the southeastern portion of the site; no cultural material was encountered, but the soils were moderately deep and intact. In the northern portion of the site, a mound of bricks, approximately $10-\mathrm{x}-15-\mathrm{m}$ and 40-50-cm tall, was observed and loosely corresponded with the map of the site produced by the SFA crew in 1996 (Figure 463). The bricks which compose the mound are machine-made and have inscriptions reading either "Corsicana" or "Mexia." According to Park Ranger Don Boyd (personal communication
2008), the mound is the bulldozed remains of a general store. Further investigation north of the site boundary revealed that cultural material was spread over a greater area than previously noted. Artifacts collected by CAS archaeologists from the northern expansion of site boundary included one stoneware lug handle fragment with gray salt glaze and Albany slip interior, a stoneware body sherd with brown and gray slip, a stoneware body sherd with Bristol glaze, and a metal keyhole (Figure 4-64).

In addition to artifacts observed on the surface, CAS archaeologists excavated six more shovel tests, four of which contained cultural material. ST 2 was located approximately $15-\mathrm{m}$ northwest of the purportedly bulldozed mound and contained a whiteware sherd with decoration at 8-25 cmbs. ST 4, located approximately 15$\mathrm{m}$ south of the mound, contained a brown bottle glass sherd at $0-10 \mathrm{cmbs}$. ST 6 was located approximately $25-\mathrm{m}$ north of the road and contained a whiteware sherd at $8-19$ cmbs. ST 7, located approximately $15-\mathrm{m}$ north of ST 6, contained a brown bottle glass sherd at 40-60 cmbs. ST 1, 5, and 7 were notably deeper and

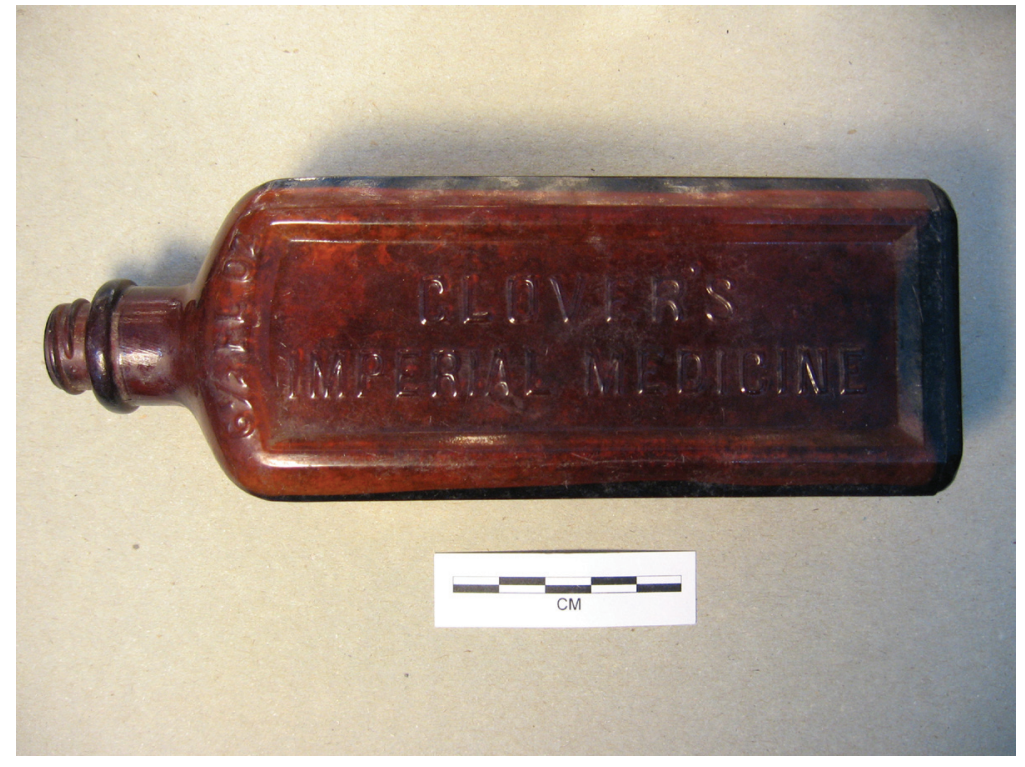

Figure 4-62. "Clover's Imperial Medicine" bottle recovered from dry gully (Lot 5). 


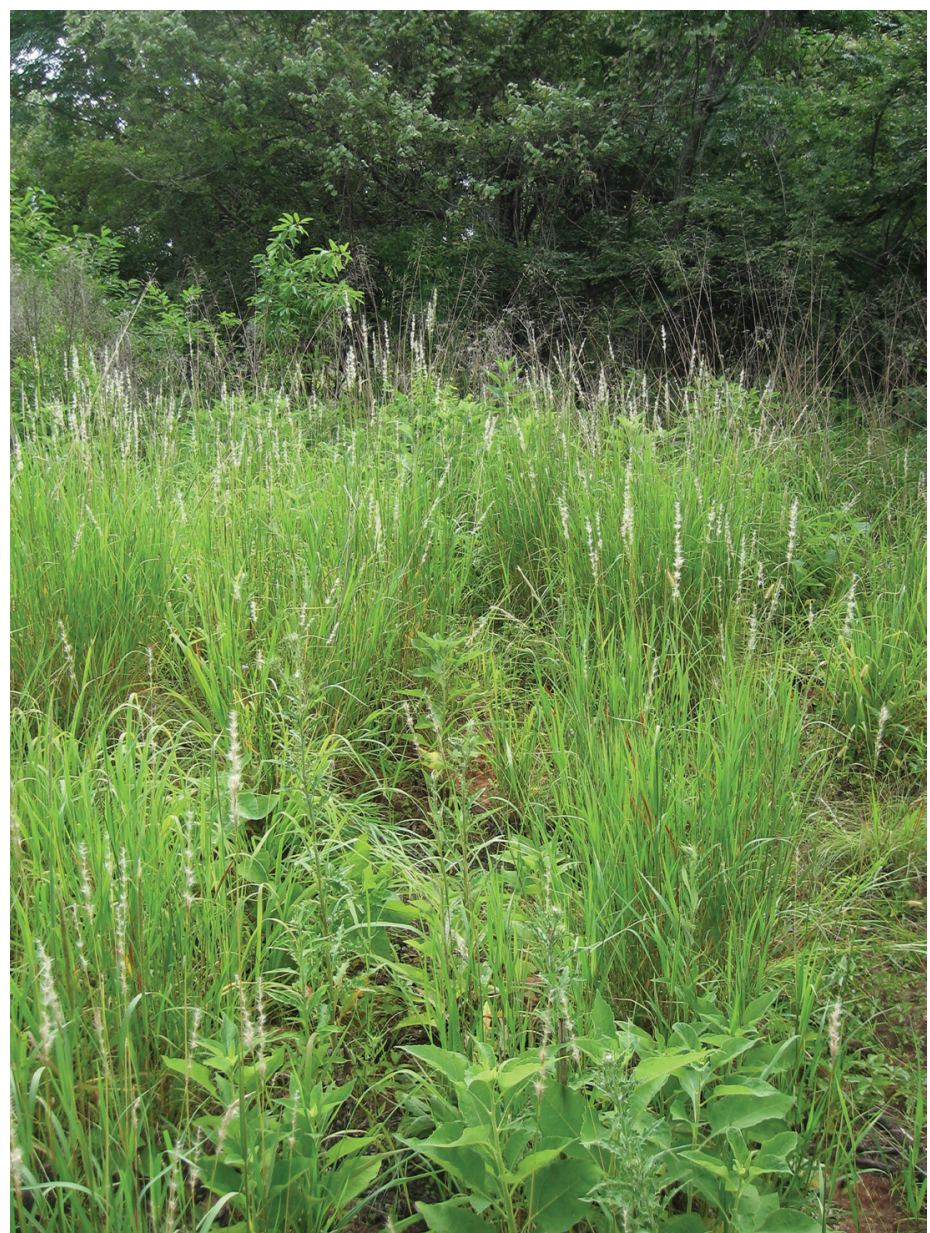

Figure 4-63. Bulldozed mound; photographed facing southwest.

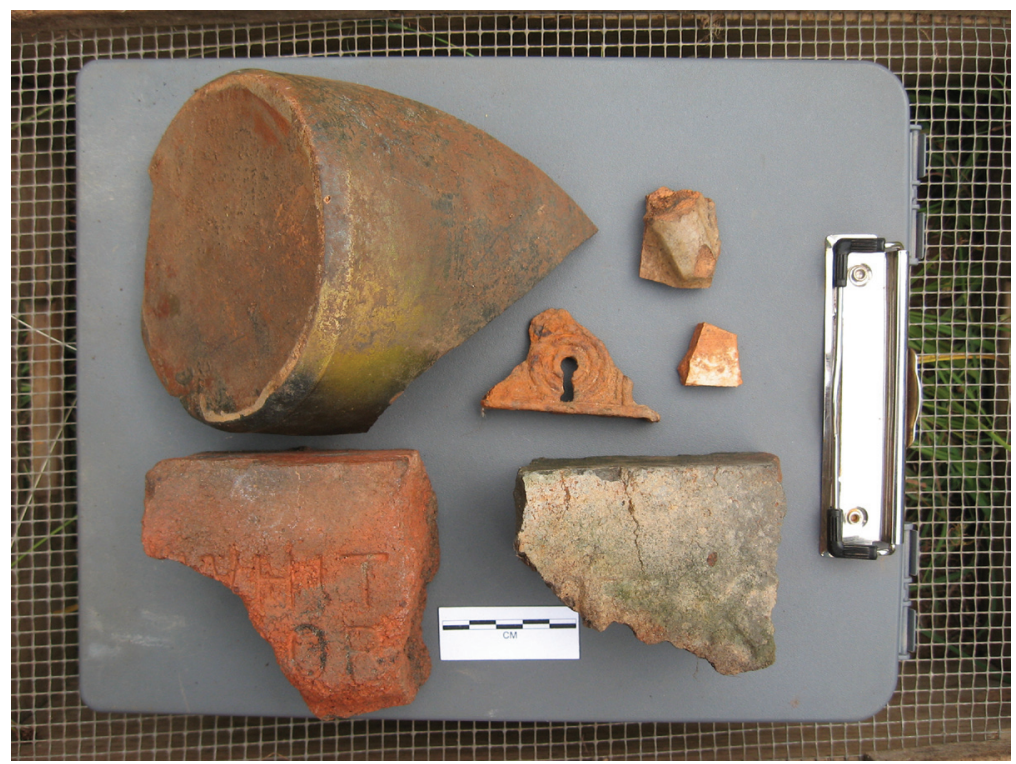

Figure 4-64. Artifacts observed on the surface in the vicinity of the bulldozed mound. determined to be colluvial sediments, while ST 2, 3, 4, and 6 were relatively shallow and reached subsoil at a depth no greater than $19 \mathrm{cmbs}$. No shovel tests were excavated north of ST 7 as ST 7 was a considerable distance from the mound and the soils appeared to be colluvial. As a result of the investigations in the area surrounding the mound, 41FT482's boundary was expanded to include positive shovel tests and surficial cultural material. In the northwest corner of the expanded site boundary, there is an eroded, historic road cut which may have provided access to the general store.

\section{Conclusions/Recommendations}

Site 41FT482 is a historic site dating to the early-twentieth to mid-twentieth century. According to Park Ranger Don Boyd (personal communication 2008), a general store occupied this location. The extensive distribution of historic material suggests they there may have been multiple structures on this landform. Further investigations in the form of archival research would be necessary to confirm dates and occupations of the site. Given the amount of material present and the intact appearance of the soils, 41FT482 is classified as a Level 1 site (High Management Priority) with excellent research potential. It is recommended as eligible for NRHP nomination or SAL designation. If this site cannot be protected from future developments, data recovery may be necessary to offset the loss of information. 


\section{FT483}

This site is a large prehistoric campsite located on the footslope of a bifurcated ridge in the southwestern portion of the park (Figure 4-65 and Figure 4-66). The ridge gently slopes down to the confluence of Big Brown Creek and the marshy backwater of Fairfield Lake. The site is mostly wooded, predominately with oak and cedar of varying ages. Edge fine sandy loam (EgE) also supports an understory of varying density and composition, from nearly impenetrable vines and shrubs beneath young trees to patches of grass in open areas and below mature hardwoods. Surface visibility also varies from less than five percent in heavily wooded areas to greater than 30 percent along the hiking trail that cuts across the site. Site 41FT483 measures approximately 60-m (N/S)-x-110-m (E/W). Modern features include hiking trails and a park bench.

\section{Levels of Work and Results}

$41 F T 483$ was
identified in 1996
when two interior
chert flakes were
recovered from a
single shovel test,
which according to
SFA records, was
found at a depth of
about 25 cmbs. Seven
additional shovel tests
excavated by the SFA
survey crew defined
the northern, western,

and southern site boundaries. In 2008, CAS archaeologists excavated additional shovel tests to define the eastern boundary and evaluate the site's integrity. A total of seven additional shovel tests, four of which were positive for cultural material, greatly expanded the boundaries of 41FT483 to the east. These positive shovel tests, numbered 1 to 4 consecutively, encountered deep sandy loams and loamy sands extending to depths

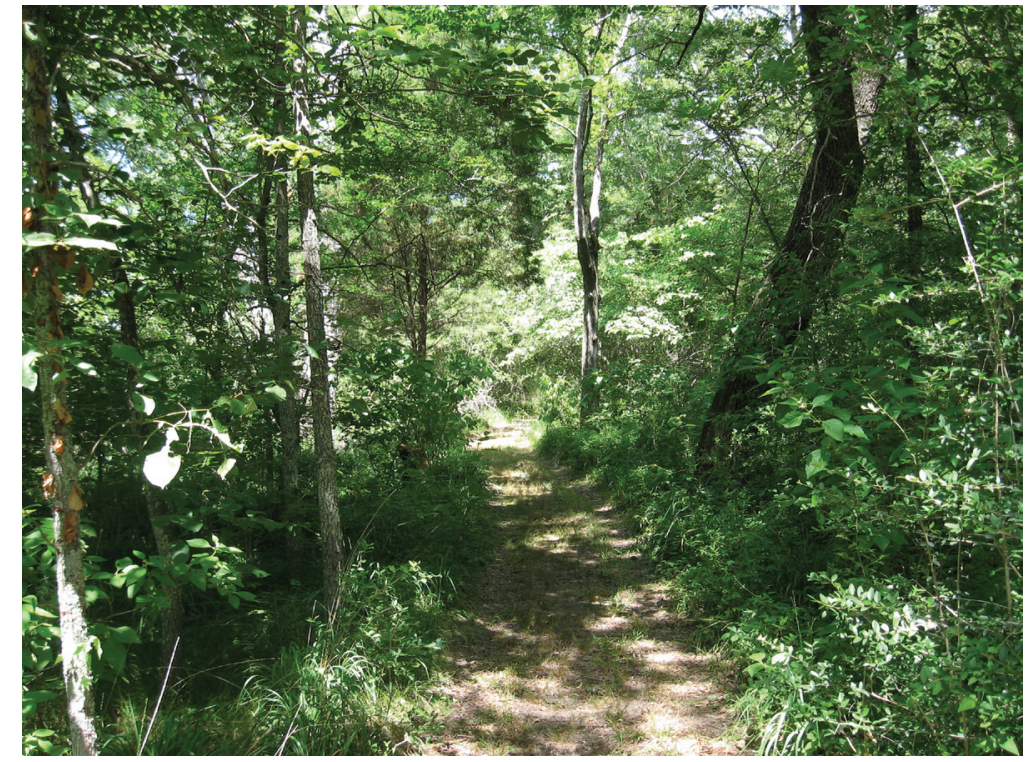

Figure 4-65. Overview of 41FT483 with Primitive Camping Area hiking trail; photographed facing east.

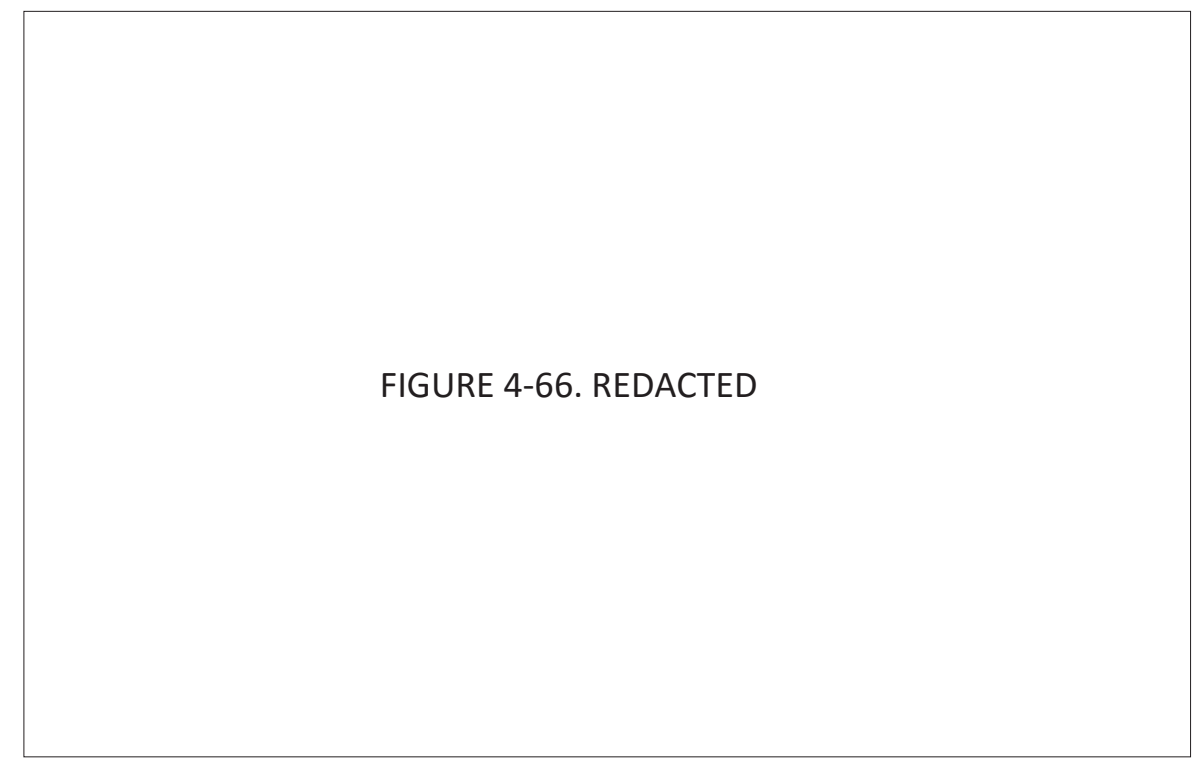

Figure 4-66. 41FT483 site map. 
of $68-100+$ cmbs. STs 1 and 2 each recovered one interior chert flake between 40 and $60 \mathrm{cmbs}$. ST 3 recovered one interior chert flake between 20 and $40 \mathrm{cmbs}$, and one interior chert flake between 40 and $60 \mathrm{cmbs}$. ST 4 recovered one interior quartzite flake between 20 and $40 \mathrm{cmbs}$; one fire-cracked rock and one piece of silicified wood showing possible cultural modifications were recovered between 40 and $60 \mathrm{cmbs}$. These artifacts were photographed but not collected. A large nutting stone was collected from the surface of the

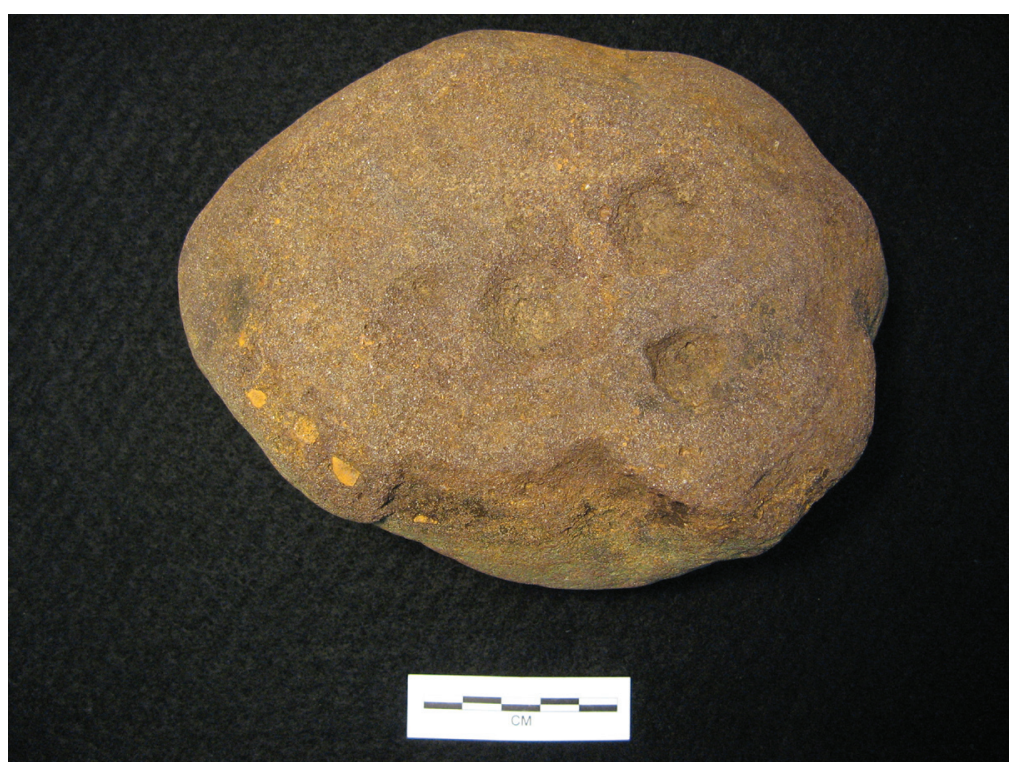

Figure 4-67. Nutting stone recovered from the northern portion of 41FT483 (Lot 3). northernmost portion of the site.

This specimen, manufactured from ferruginous sandstone and measuring 16.5$\mathrm{x}-13-\mathrm{x}-7-\mathrm{cm}$, exhibits grinding and pitting on opposing surfaces (Figure 4-67, Lot 3). Shallow topsoil $17 \mathrm{~cm}$ in thickness was encountered in a negative shovel test (ST 7) 20-m north of the nutting stone. Areas of exposed subsoil were also observed along the toeslope of the ridge.

\section{Conclusions and Recommendations}

Site 41FT483 is a large prehistoric campsite probably dating to the Archaic and/or Late Prehistoric periods. Although the northern portion of this site is eroded and deflated, the southern portion contains buried cultural deposits between 20 and $60 \mathrm{cmbs}$. As such, this site has good research potential and is classified as a Level 2 site (Moderate to High Management Priority). Without further work, the site's eligibility for NRHP nomination or SAL designation is unknown. Further eligibility testing will be necessary if future projects will impact the site.

\section{FT484}

This site is a prehistoric campsite located on the crest of a narrow ridge near the southwest corner of the park (Figure 4-68 and Figure 469). The northeasterly trending ridge overlooks an unnamed, intermittent tributary of Big Brown Creek about $90 \mathrm{~m}$ to the southeast. The site is wooded with a mixture of hardwoods and cedar, with several mature and very large trees. Tabor fine sandy loam $(\mathrm{TaB})$ also supports a very thick understory of vines and shrubs, which, together with a thick layer of leaf litter, prohibited inspection of the ground surface. The recorded portion of 41FT484 measures approximately 140m (N/S)-x-100-m (E/W). However, the site may extend west, outside of the park's boundary.

\section{Levels of Work and Results}

41FT484 site was discovered in 1996 during the excavation of a series of shovel tests along the ridge crest. According to SFA records, a total of five positive shovel tests were excavated in 1996. However, the material provided to CAS for the 2008 reassessment contained artifacts from only 


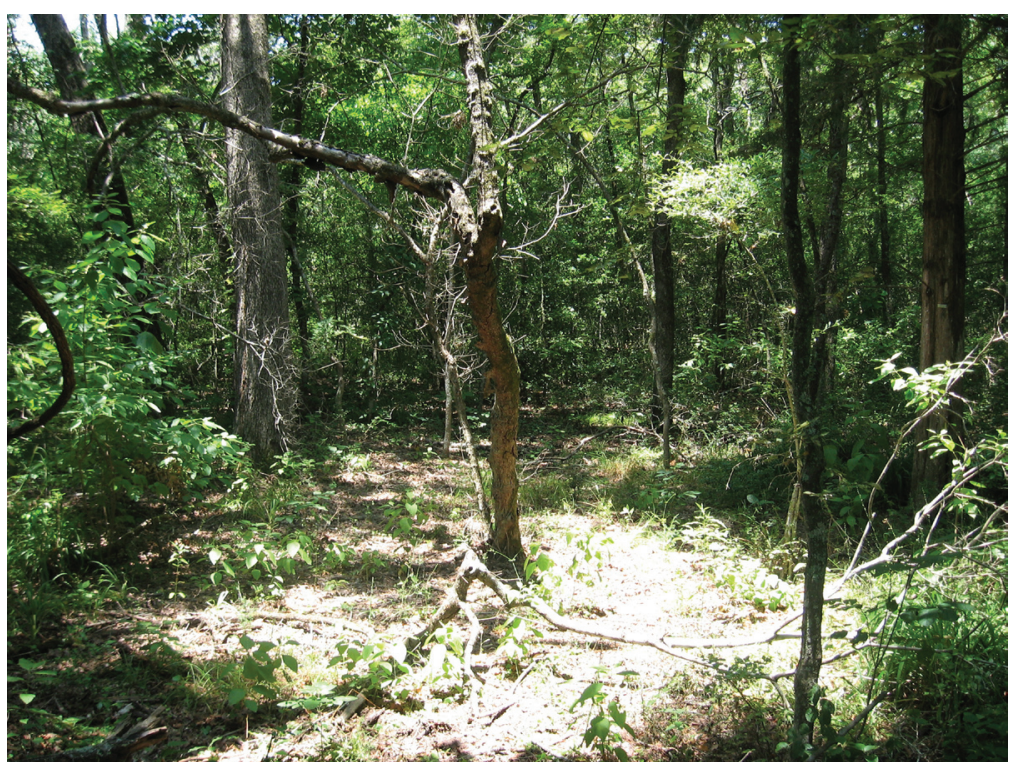

Figure 4-68. Overview of 41FT484; photographed facing west.

FIGURE 4-69. REDACTED

Figure 4-69. 41FT484 site map. four shovel tests. These artifacts include two interior chert flakes, one exterior silicified wood flake, one possible quartzite flake, and one fire-cracked rock. Additional negative shovel tests excavated by the SFA survey crew defined the northern and southern boundaries of the site. The eastern and western site boundaries are defined, respectively, by the slope of the landform and the western boundary of the park. In 2008, CAS archaeologists excavated one shovel test to evaluate the integrity of 41FT484. This test encountered sandy loam and loamy sand overlying a sandy clay subsoil at $27 \mathrm{cmbs}$. No artifacts were recovered.

\section{Conclusions and Recommendations}

41FT484 is a prehistoric encampment from which no diagnostic artifacts were recovered. Given the low-density of artifacts and only moderately-deep sediments, this site has only moderate research potential. As such, 41FT484 is classified as a Level 3 site (Moderate to Low Management Priority). Although the site's eligibility for NRHP nomination or SAL designation is unknown, CAS recommends that the THC be allowed to comment on any work that might be necessary.

\section{FT485}

Site41FT485isalargescatterofhistoric debris and features located, mostly, atop a ridge knoll in the southwest portion of the park. Adjacent to the cultural material is a pipeline cut that likely impacted the 
site significantly. The vegetation, supported by Edge fine sandy loam (EgE), varies from tall, thick grasses in the pipeline cut to an adjacent wooded area with a thick understory of grass, vines, and shrubs (Figure 4-70). Several large oak and cedar trees mark the site along the pipeline. Site 41FT485, delineated by the extent of surficial artifacts and features, measures approximately 100-m (N/S)-x-95-m (E/W) (Figure 471).

\section{Level of Effort and Results}

\section{The SFA crew discovered 41FT485 in} 1996. At that time, two shovel tests were excavated, but the site was delineated by the spread of cultural material on the surface. Both shovel tests excavated by the SFA crew yielded cultural material. Artifacts collected from shovel tests by the SFA crew include a clear bottle glass sherd with embossing, a clear vessel glass sherd, a clear bottle glass sherd, a brown bottle glass sherd, and a fragment of plaster. Some surficial cultural material was also collected. Included in the surface collection is an earthenware basesherd with an unidentified maker's mark, an earthenware base sherd with an unidentified

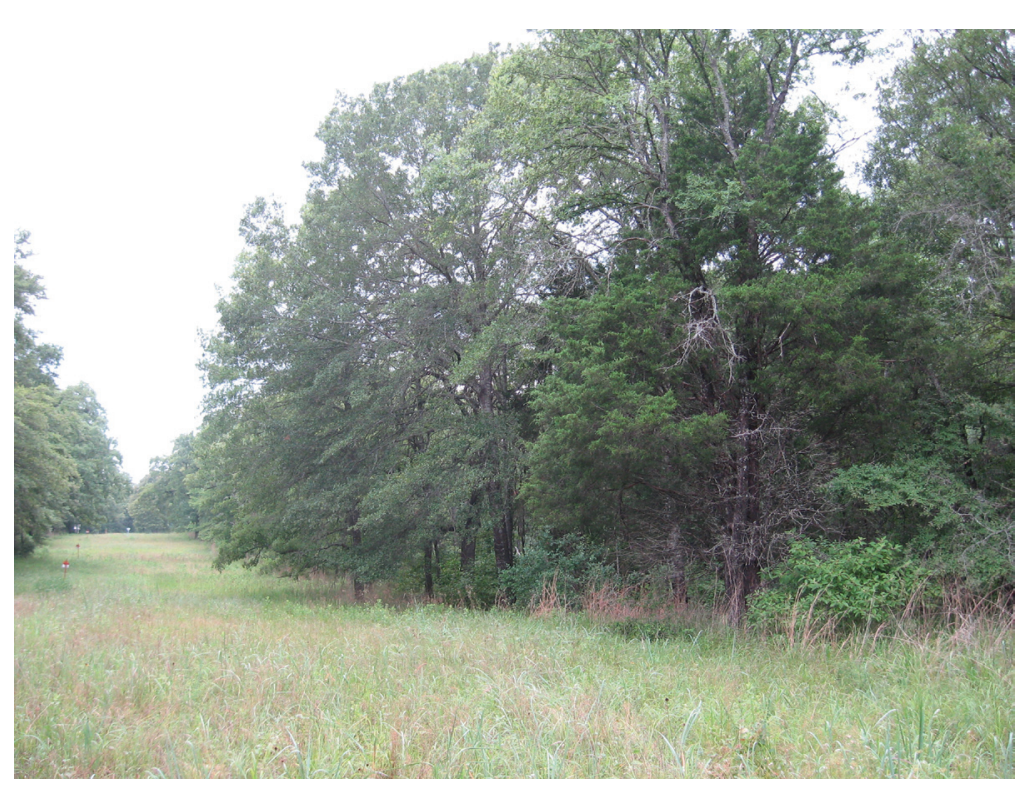

Figure 4-70. Overview of 41FT485; photographed facing west.
FIGURE 4-71. REDACTED

Figure 4-71. 41FT485 site map. 
maker's mark, a solarized bottle glass sherd, three wire nails, a blue vessel glass sherd, and a stoneware base sherd with gray salt glaze and Albany slip interior. In addition to the artifacts collected from the surface, a pile of low-fired bricks and two possible well depressions were observed in a line adjacent and parallel to the pipeline cut.

In 2008, CAS archaeologists returned to 41FT485. The depressions and brick pile which characterized the site were still present (Figure 4-72 and Figure 4-73). Another depression was located approximately 40-m southwest of the western-most depression. The depressions are approximately $3.25 \mathrm{~m}$ in diameter and the depths range from 25 to $60 \mathrm{cmbs}$. The pile of low-fired brick is approximately $2.5 \mathrm{~m}$ in diameter and reaches approximately $25 \mathrm{~cm}$ in height. A variety of metal scraps were observed throughout the wooded area of the site. The only artifact collected by CAS archaeologists is a complete, brown snuff bottle with a square base (Figure 4-74, Lot 4)).

\section{Conclusions/Recommendations}

Site 41FT485 is a large scatter of historic artifacts and features, possibly representing the former location of a historic structure that dates from the late-nineteenth to early-twentieth century. Although the pipeline construction has probably impacted the site significantly, the 


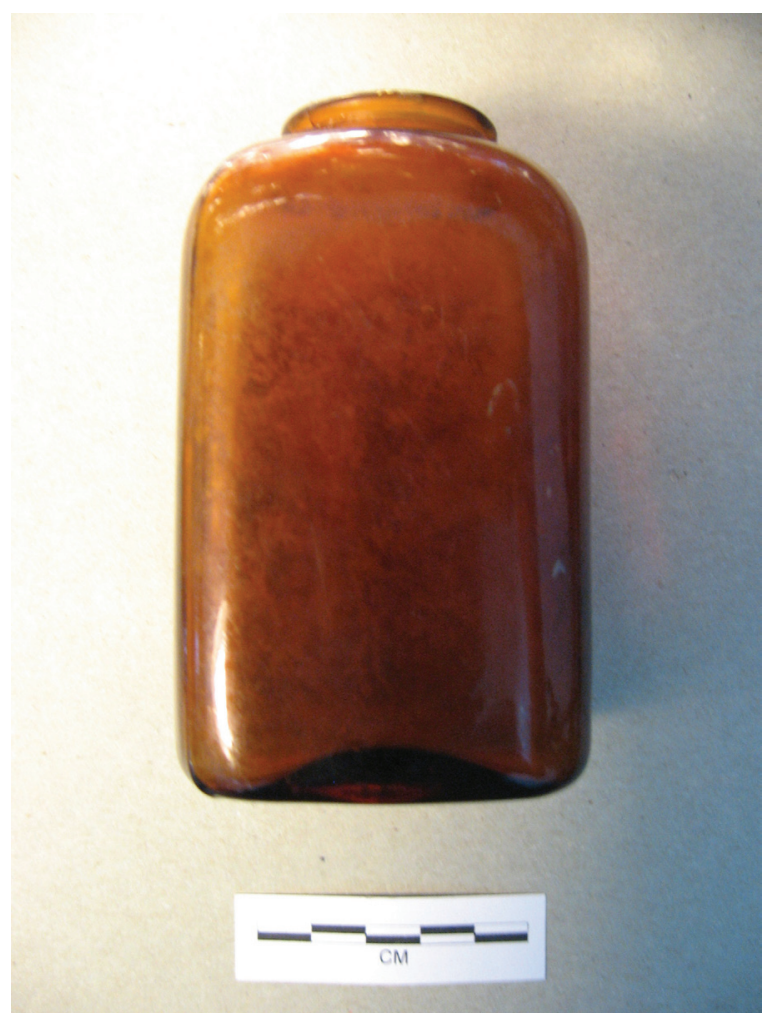

Figure 4-74. Complete, brown snuff bottle from 41FT485 (Lot 4).

\section{FT486}

This site is a group of surficial historic features located in the southwest corner of the park near Ranch Road 3285 (Figure 4-75 and Figure 4-76). Situated on a gentle slope overlooking Big Brown Creek about $225 \mathrm{~m}$ to the northwest, 41FT486 encompasses an area measuring approximately 160-m (N/S)-x-85-m (E/W). The site is mostly wooded with cedar, hickory, and oak. Edge fine sandy loam (EgE) also supports a thick understory of various vines and shrubs, as well as patches of grass in the open areas. The most prominent feature is a $3.5 \mathrm{~m}$ in diameter by about $40-\mathrm{cm}$ deep circular depression, possibly the remnants of a well. A relatively young hickory tree, perhaps 30 years old, has grown out of this depression. The northern end of the site is marked by three large ferruginous sandstone rocks equally spaced 1.9$m$ apart (Figure 4-77). These rocks, possibly piers for a structure, measure $49-\mathrm{x}-43-\mathrm{cm}, 53-\mathrm{x}-37-\mathrm{cm}$, and 53-x-29-cm. Remnants of wire fencing were also noted near the possible piers and along the unnamed dirt road that bisects the site.

\section{Levels of Work and Results}

In 1996, the SFA survey crew excavated seven shovel tests in the vicinity of the circular depression. No artifacts were recovered from these shovel tests. Two brick fragments, a tin bucket, and a beer bottle were observed on the surface but not collected. In 2008, the surface visibility was very low and CAS archaeologists were unable to locate any diagnostic artifacts. The only artifact noted on the surface was a coil of barbed wire near the possible sandstone piers.

\section{Conclusions and Recommendations}

The features recorded at 41FT486 probably represent the remnants of a twentieth century homestead or the outbuildings of a twentieth century farmstead. The location of the three possible piers at the northern edge of the site closely correspond with the location of a structure depicted on USGS quadrangle maps of the area dated as late as 1982. Given the probable late date of occupation, it is unlikely that this site good research potential. 41FT486 is classified as a Level 3 site (Moderate to Low Management Priority). Although the site's eligibility for NRHP nomination or SAL designation is unknown, CAS recommends that the THC be allowed to comment on any work that might be necessary.

\section{FT487}

This site is a surface scatter of historic artifacts located along an unnamed dirt road near the western park boundary (Figure 4-78 and Figure 4-79). 41FT487 is situated on the gentle southern sideslope of a large bifurcated ridge overlooking Fairfield Lake. The scatter measures 


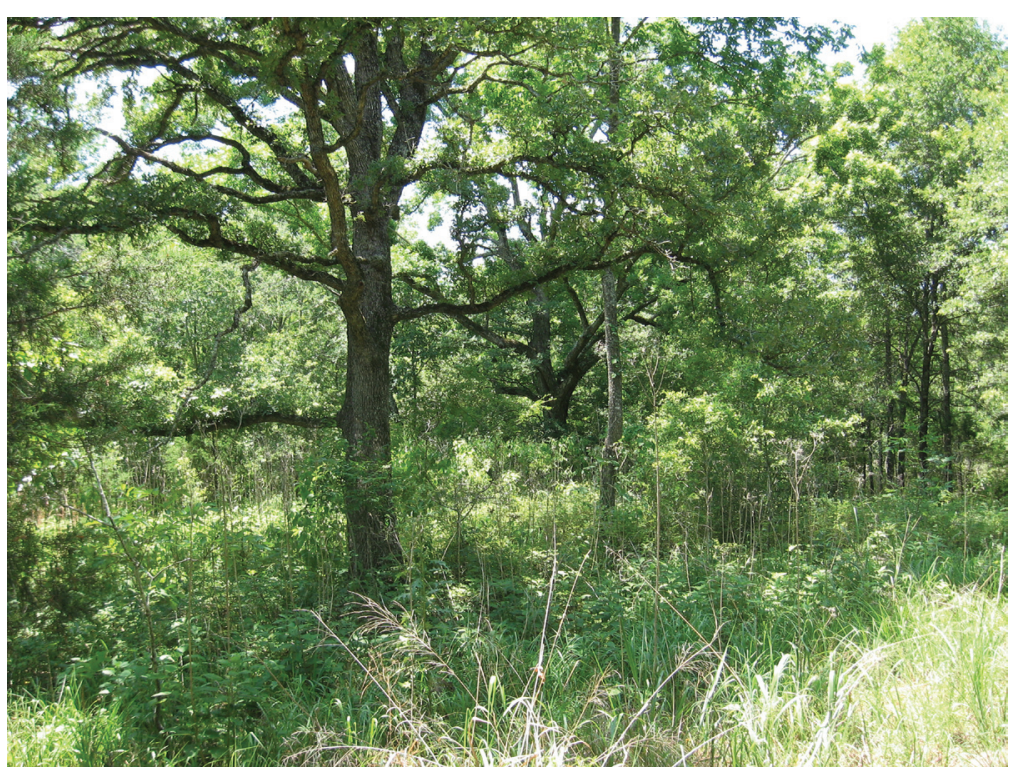

Figure 4-75. Overview of 41FT486; photographed facing southeast.

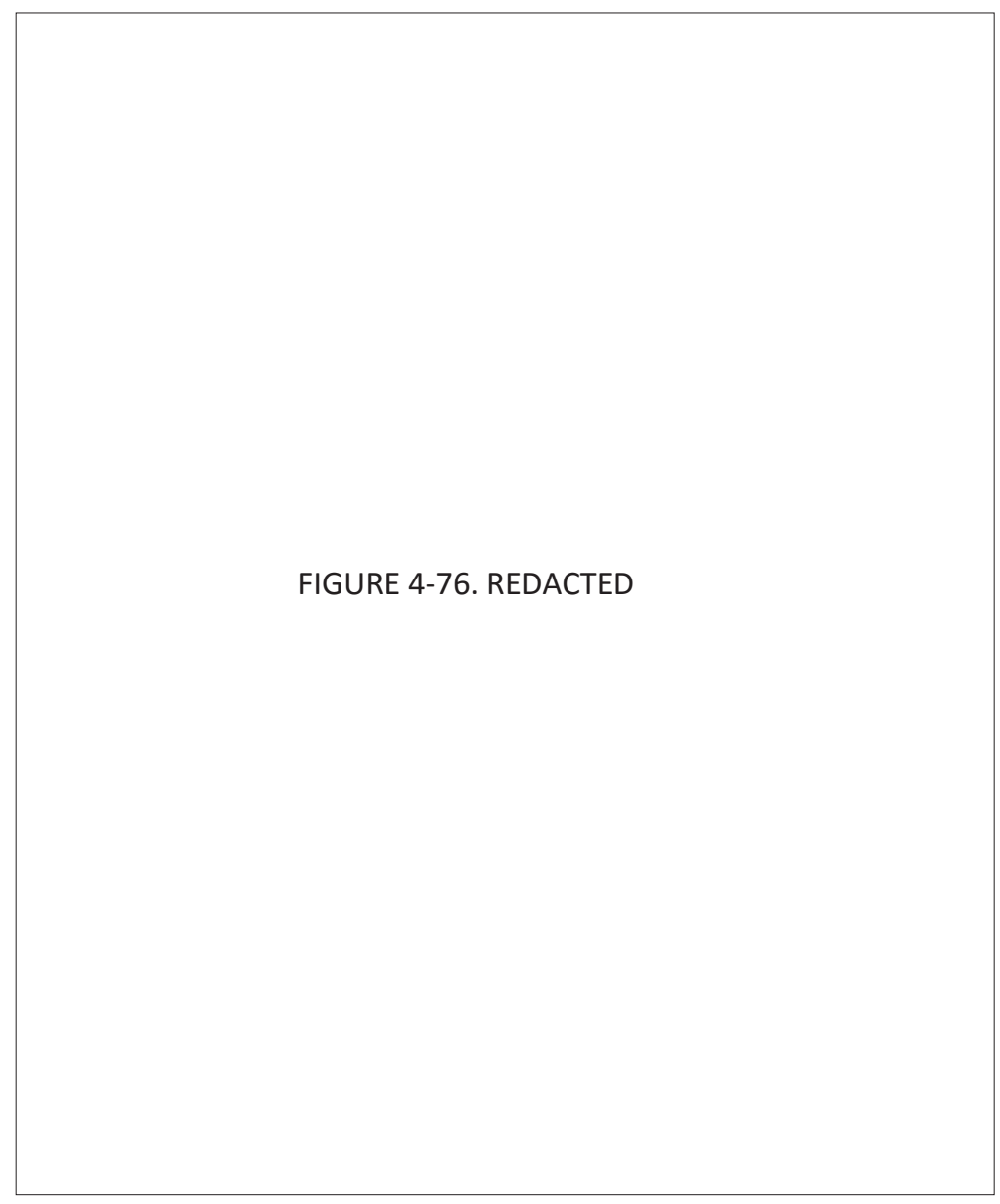

Figure 4-76. 41FT486 site map. 


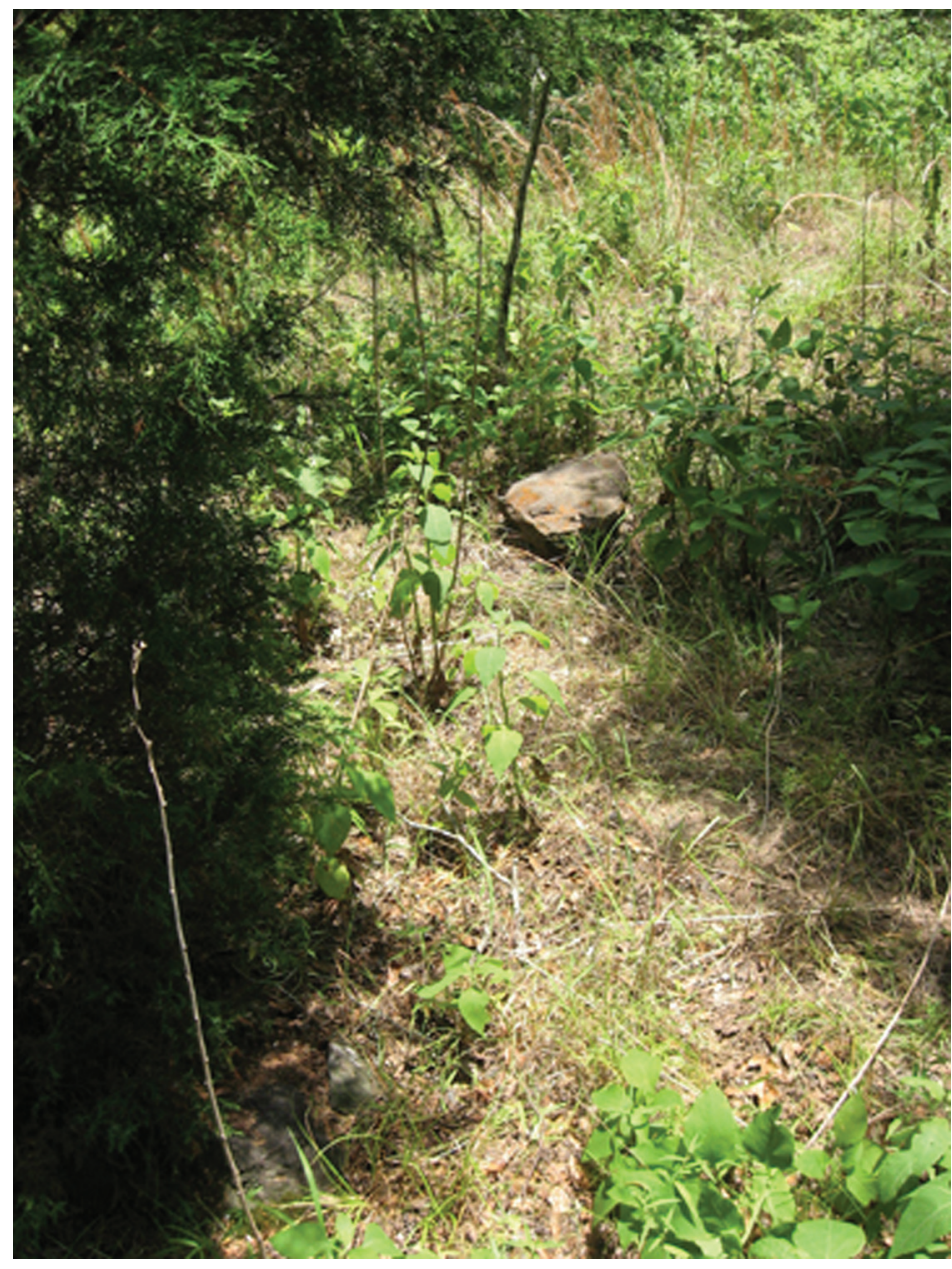

Figure 4-77. Linear rock feature, possible pier support, at 41FT486; photographed facing north.

approximately $10-\mathrm{m}(\mathrm{N} / \mathrm{S})-\mathrm{x}-35-\mathrm{m}(\mathrm{E} / \mathrm{W})$, and is mostly wooded with oak and young cedar. Edge fine sandy loam (EgE) also supports a thick understory of various shrubs, vines, and patchy grass. A very large oak tree, presumably over 100 years old, and a pump/well station are on a nearby ridge knoll to the southwest.

\section{Levels of Work and Results}

In 1996, the SFA survey crew collected a small sample of artifacts from the surface, including one sherd of Bristol glazed stoneware, one sherd of milk glass, and two sherds of refined earthenware, one of which exhibits a partial, unidentified, English maker's mark.
During the 2008 reassessment, CAS archaeologists observed but did not collect a light scatter of artifacts along the dirt road cut, and to a lesser degree, inside the tree line where surface visibility was less than 30 percent. These artifacts included low-fired brick fragments, sherds of refined earthenware, clear vessel glass, solarized glass, and fragments of rusted metal objects. CAS archaeologists also excavated two shovel tests inside the tree line, neither of which recovered artifacts.

\section{Conclusions/Recommendations}

Site 41FT487 is a late-nineteenth to early-twentieth century historic scatter of domestic and architectural debris. This surficial scatter, and the unusually large oak tree previously mentioned, may be the remnants of an occupation of the nearby ridge knoll. The knoll, however, had been severely disturbed by park infrastructure construction. 41FT487 is classified as a Level 4 site (Low Management Priority). While its location should be noted and taken into consideration if threatened by future construction projects, CAS recommends that no further work is warranted at this site, and it is considered ineligible for nomination to the NRHP or for SAL designation.

\section{FT488}

Site 41FT488 is a prehistoric lithic scatter located on a low, irregularly-shaped rise on the north edge of a broad ridge overlooking Little Brown Creek in the center of the park. The site is approximately $75-\mathrm{m}$ east of a paved park road providing access to a boat ramp. The vegetation, 


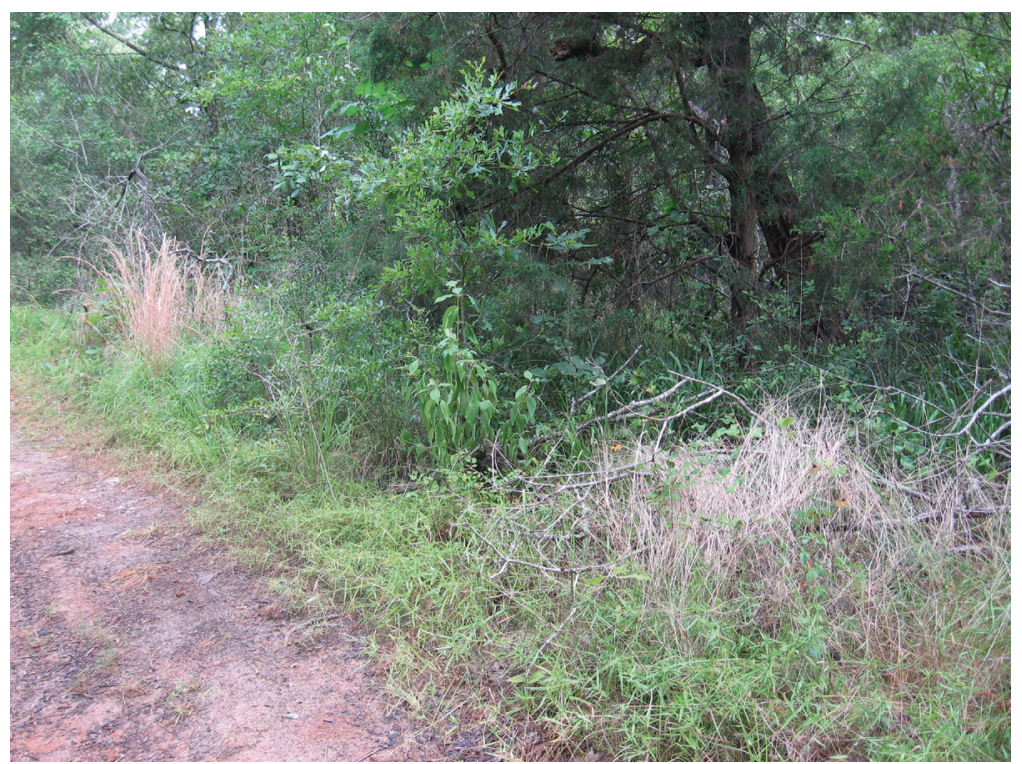

Figure 4-78. Overview of 41FT487; photographed facing west.

FIGURE 4-79. REDACTED supported by Tabor $(\mathrm{TaB})$ fine sandy loam, consists primarily of young oaks, some young cedars, and a relatively thick understory of tall grasses and shrubs (Figure 4-80). Delineated to the north by an intermittent drainage and to the east, south, and west by sterile shovel tests, 41FT488 measures approximately 95-m (N/S)-x-95-m (E/W) (Figure 481).

\section{Level of Effort and Results}

The SFA crew discovered 41FT488 in 1996. At that time, nine shovel tests were excavated. Three of these shovel contained cultural material, including two exterior silicified wood flakes, three possible flakes of ironstone, and a possible flake of silicified wood. All of the shovel tests containing cultural material were excavated on the top of the low rise. When CAS archaeologists returned to $41 \mathrm{FT} 488$ in 2008 , three additional shovel tests were excavated to better define the site's boundary. Two shovel tests were placed off the eastern edge of the rise, and one shovel test was excavated on the southern portion of the rise. All three shovel tests were devoid of cultural material. ST 1, which was approximately

Figure 4-79. 41FT487 site map. 
$30-\mathrm{m}$ south of the intermittent drainage, reached subsoil at a depth of $64 \mathrm{cmbs}$ while ST 2 and 3 reached subsoil at a maximum depth of $48 \mathrm{cmbs}$. No cultural material is present on the surface. The location of the shovel tests containing cultural material suggest that the site is confined to the top of the low rise.

\section{Conclusions/ \\ Recommendations}

Site 41FT488 is a prehistoric lithic scatter of unknown age. Given the low-density

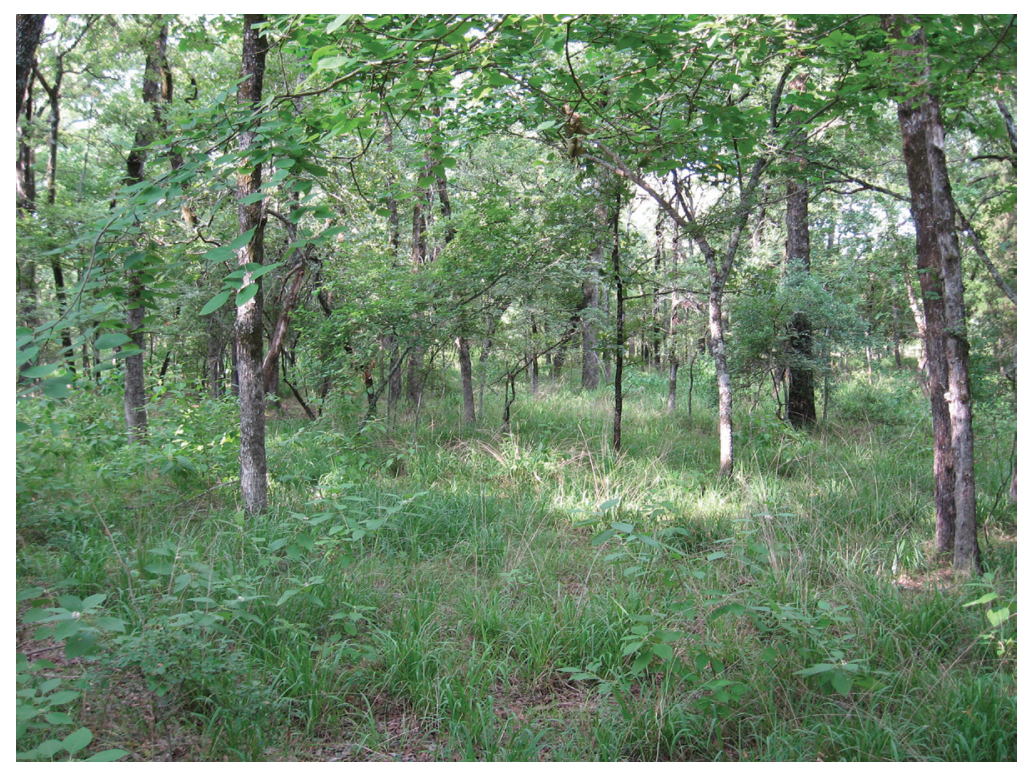

Figure 4-80. Overview of 41FT488; photographed facing southwest. of artifacts and the moderate depth of soils, this site has only moderate research potential. As such, 41FT488 is classified as a Level 3 site (Moderate to Low Management Priority). Although the site's eligibility for NRHP nomination or SAL designation is unknown, CAS recommends that the THC be allowed to comment on any work that might be necessary.

\section{FT496}

This site, perhaps FIGURE 4-81. REDACTED best described as an isolated prehistoric find, is located adjacent to State Park Road 64 near the eastern park boundary (Figure 4-82 and Figure 4-83). 41FT496 is situated

on a somewhat narrow ridge overlooking Ball Branch Creek to the southwest. The landform has been severely disturbed by construction activities 
and the area is now used by park personnel as a storage and staging area, and as a dump for waste generated at the park's fish cleaning stations (see Figure 4-82). Portions of the landform appear to have been removed, presumably by bulldozer for construction fill. The remaining landform is mostly wooded with oak of various ages and young cedar. Gasil fine sandy loam (GfB) also supports a thin understory of grass in the wooded areas and tall grass and weeds in the clearings. The site is also marked by three linear push piles and two open pits. The pits, which measure approximately 2-x-2-m, are not dissimilar to the roughly square-shaped pits observed at other sites in the park (see 41FT280 and 41FT497).

\section{Levels of Work and Results}

41FT496 was recorded in 1996 after Park Superintendent Dennis Walsh gave the SFA survey crew a fragment of a barbed, basally-notched, untyped, Archaic projectile point reportedly found on or near the landform (Figure 4-84, Lot 1). The SFA crew excavated four shovel tests in the vicinity of the find, but all were negative. In 2008, CAS archaeologists thoroughly inspected the pushpiles, the backdirt piles adjacent to the open pits, and the ground surface, which offered

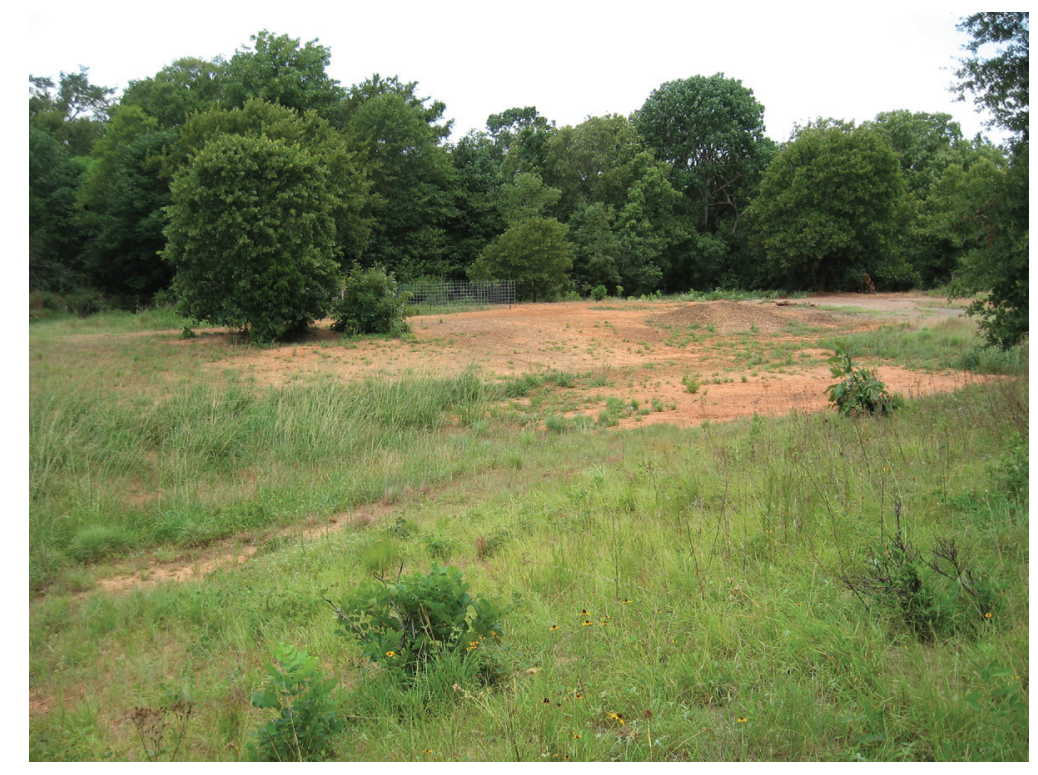

Figure 4-82. Overview of 41FT496; photographed facing west.

FIGURE 4-83. REDACTED

Figure 4-83. 41FT496 site map. 
visibility over 30 percent in some places. No cultural material was observed.

\section{Conclusions/Recommendations}

Given the apparent paucity of cultural material, this site has little or no research value. 41FT496 is ineligible for NRHP nomination or SAL designation, and is classified as a Level 4 site (Low Management Priority). Although the location of the site should be noted if threatened by future construction projects, CAS recommends that no further work is warranted at 41FT496.

\section{FT497}

Located on the slope and top of a south by southwest trending spur of a broad ridge, 41FT497 is marked by four pit features-three rectangular and one square-with clearly visible, adjacent backdirt piles. The vegetation, supported by

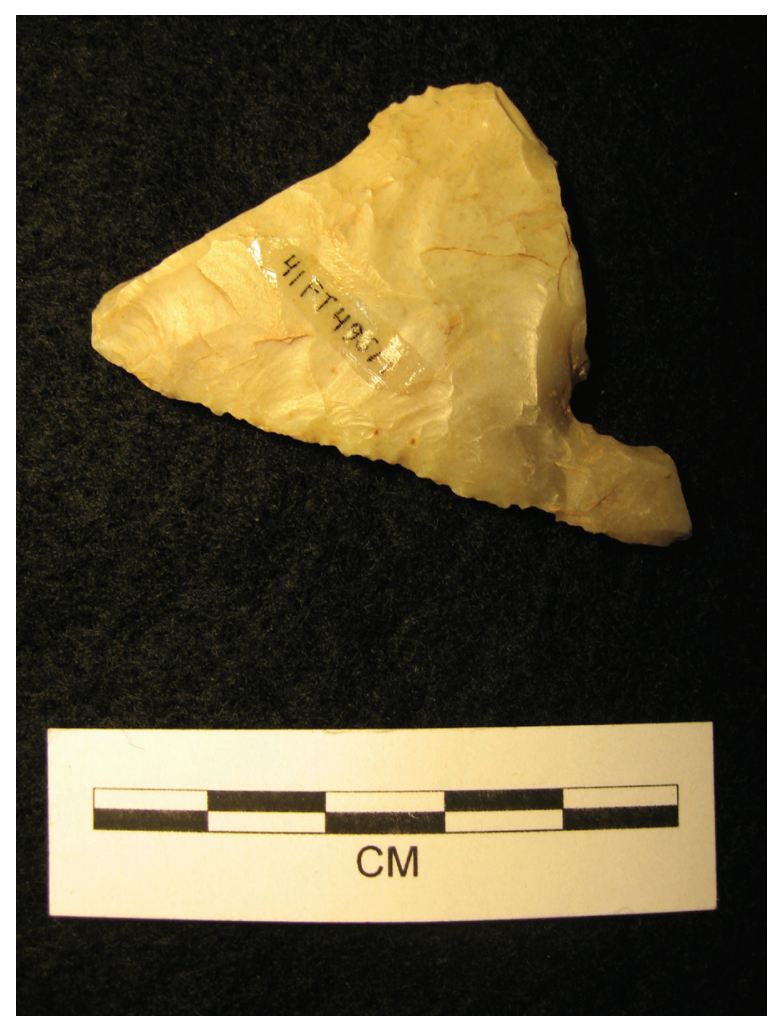

Figure 4-84. Untyped, Archaic projectile point recovered from 41FT496 (Lot 1).
Edge fine sandy loam (EgE), consists primarily of mature oaks with a thin, grassy understory (Figure 4-85). Leaf litter and grass obscure the surface visibility to less than 15 percent. The site's boundary is delineated by the extent of pit features and measures approximately 40-m (N/ S)-x-20-m (E/W) (Figure 4-86).

\section{Level of Effort and Results}

Site 41FT497 was discovered by the SFA crew in 1996. At this time, no shovel tests were excavated and no map was made. SFA records reveal that they interpreted the site as a prehistoric and historic gravel quarry. One grinding/hammer stone made of foreign material was observed and collected. In 2008, CAS archaeologists returned to 41FT497. The pit features were still exposed, but no cultural material was present on the surface. Two shovel tests were excavated in 2008; both shovel tests were sterile and reached subsoil at a maximum depth of $34 \mathrm{cmbs}$.

\section{Conclusions/Recommendations}

Given the apparent paucity of cultural material, the origins/functions of the pit features are unknown and thus, this site has little or no research potential. 41FT497 is ineligible for NRHP nomination or SAL designation, and it is classified as a Level 4 site (Low Management Priority). Although the location of the site should be noted if threatened by future construction projects, CAS recommends that no further work is warranted at 41FT498 at this time.

\section{FT498}

This site, perhaps best described as an isolated prehistoric find, is located near State Park Road 64 in the eastern portion of the park (Figure 4-87 and Figure 4-88). 41FT498 is situated on the gentle sideslope of a small ridge overlooking Fairfield Lake. The area is wooded, predominately with 


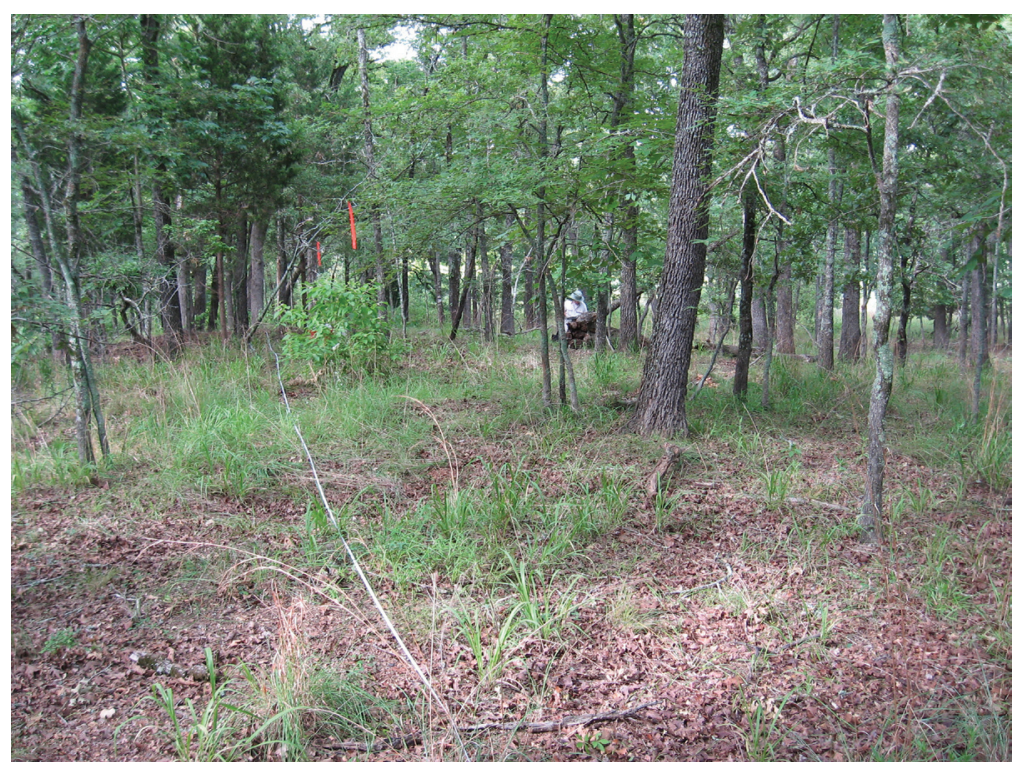

Figure 4-85. Overview of 41FT497; photographed facing south.

FIGURE 4-86. REDACTED oak and cedar. The soils, mapped as Edge fine sandy loam (EgE), also support a dense understory of various young trees and shrubs. Thick leaf litter obscures the ground surface, and visibility is less than 20 percent.

\section{Levels of Work and Results}

In 1996, the SFA survey crew collected a nutting stone from the surface of this site. The stone, made of ferruginous sandstone, measures approximately 10$\mathrm{x}-9-\mathrm{x}-5-\mathrm{cm}$, and exhibits pits on opposing sides. Although the vicinity of the find was not mapped, the site was plotted on a small ridge spur. On that ridge spur, CAS archaeologists were unable to locate a sandstone outcrop, which according to the SFA description, marks the location of the site. However, appreciable amounts of sandstone were observed on the ridge at a higher elevation. CAS archaeologists excavated two shovel tests at the higher elevation with the supposition that the location of the find was plotted incorrectly on the USGS quadrangle. These shovel tests (ST 1 and 2) encountered shallow, gravelly loamy sands overlying gravelly clay loam subsoil at depths of 16-22 cmbs. No artifacts were recovered from the shovel tests, and no cultural material was observed on the surface.

Figure 4-86. 41FT497 site map. 


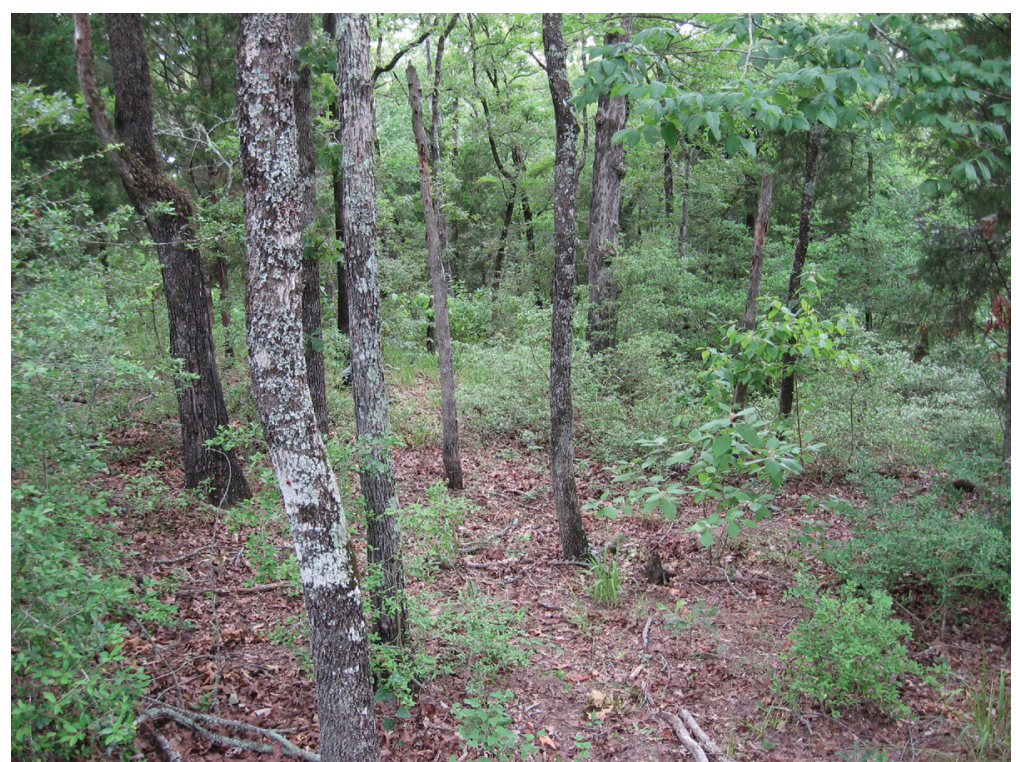

Figure 4-87. Overview of 41FT498; photographed facing north. further work is warranted at this time.

\section{FT499}

Site 41FT499 is marked by a roughly circular depression and an adjacent historic road bed running northeast to southwest (Figure 4-89 and Figure 4-90). The site is located on a broad ridge sloping gently to the west towards Big Brown Creek. Aside from a small, grassy clearing southwest of the depression, the vegetation consists primarily of young and mature oak with a thin, grassy understory. The soil mapping unit in the vicinity of the site is Edge fine sandy loam (EgE).

FIGURE 4-88. REDACTED

Figure 4-88. 41FT498 site map.

\section{Conclusions/Recommendations}

This site has little or no research value given the paucity of cultural material. 41FT498 is ineligible for NRHP nomination or SAL designation, and is classified as a Level 4 site (Low Management Priority). Although the location of the site should be noted if threatened by future construction projects, CAS recommends that no

\section{Level of Effort and Results}

The SFA crew discovered 41FT499 in 1996. One shovel test revealed very thin topsoil and yielded no cultural material. No cultural material was observed or collected from the surface either. The function of the depression was not discerned. CAS archaeologists returned to the site in 2008. The depression was located and one shovel test was excavated approximately six meters to the southwest. This shovel test revealed very shallow subsoil, which was encountered at approximately $11 \mathrm{cmbs}$. No cultural material was observed or collected from the 2008 shovel test or 
from the surface. Approximately 15-m southeast of the depression is a historic road bed that becomes heavily eroded close to the Primitive Camping Area access trail.

\section{Conclusions/ Recommendations}

Site 41FT499 consists of a depression of unknown origin and a historic road bed, both of unknown age. Given the apparent paucity of cultural material, this site has little or no research potential. Site 41FT499 is classified as a Level 4 site (Low Management Priority). Although the location of the site should be noted and taken into consideration if threatened by future construction projects, CAS recommends that no further work is warranted at 41FT499 at this time. Site 41FT498 is ineligible for NRHP nomination or SAL designation.

\section{FT630}

This site is an abandoned historic cemetery located adjacent to State Park Road 64 near the northeast corner of the park (Figure 4-91 and Figure 492). Near the head of a dendritic drainage, the site lies atop a large, flat ridge. As recorded, the cemetery measures at least $20-\mathrm{m}$ (N/S)-x-14-m (E/W), but it may be considerably larger. Edge fine sandy loam (EgE) supports oak tress of various ages,

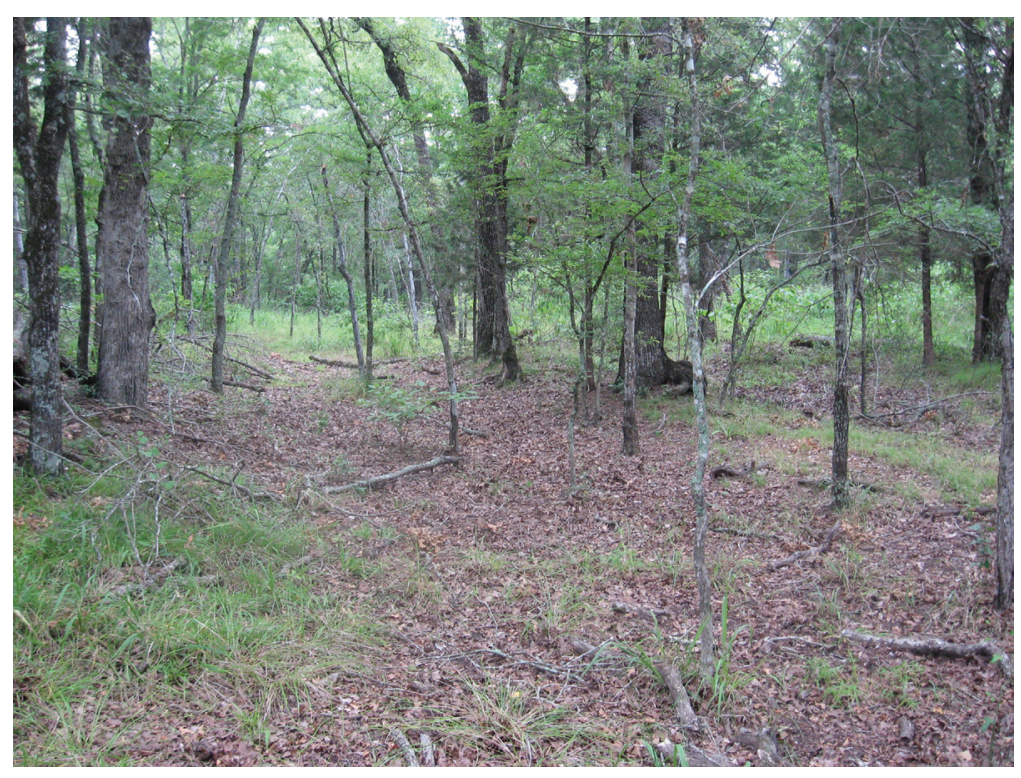

Figure 4-89. Overview of 41FT499 feature a historic road cut; photographed facing northeast.

FIGURE 4-90. REDACTED

Figure 4-90. 41FT499 site map. 
young cedar, and a relatively thin understory of grasses, vines, and shrubs. The site is marked by a single headstone which was photographed and described by Jasinski (2002). The marker is now broken at the base and lying flat on the ground (Figure 4-93). Although eroded, the engraving on the headstone is mostly discernible and reads:

EASTER
WIFE OF
D. MILES
BORN _ 1835
DIED JUNE 19
1887
BUT NOT FORGOTTEN

\section{Levels of Work and Results}

In 2008, CAS archaeologists returned to the cemetery to record its location and condition, and examine the surrounding area in an effort to identify additional grave locations without the use of intrusive techniques or remote sensing technology. The outlines of six probable sunken graves, each measuring approximately 1-x-2-m, were recorded west of the road near the headstone. Two smaller and less distinct depressions, each measuring approximately .5-x-1-m and possibly representing sub-adult internments, were also observed in the general vicinity of the headstone. A ninth depression, measuring .5-x-2-m and possibly representing an additional adult grave, was observed about 25-m east of the road.

\section{Conclusions/Recommendations}

While portions of this cemetery may have been disturbed by road construction, the presence of a nineteenth century headstone, six probable grave depressions, and three possible grave depressions suggests that several burials remain intact. As such, 41FT630 appears eligible for nomination to the NRHP or for SAL designation. This site is classified as a Level 1 site (High Management Priority) and should be avoided and protected. If any ground-disturbing undertakings are scheduled in the vicinity of 41FT630, CAS recommends that ground penetrating radar or other suitable techniques be employed to identify any graves not visible on the surface. 


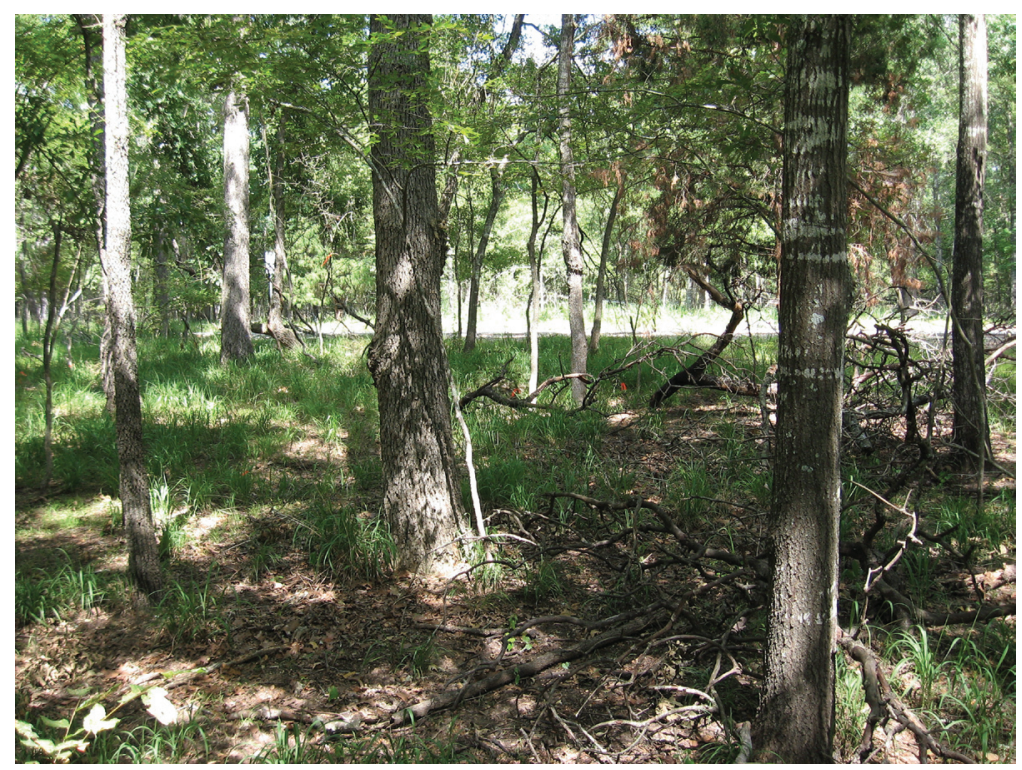

Figure 4-91. Overview of 41FT630; photographed facing east.

FIGURE 4-92. REDACTED

Figure 4-92. 41FT630 site map. 


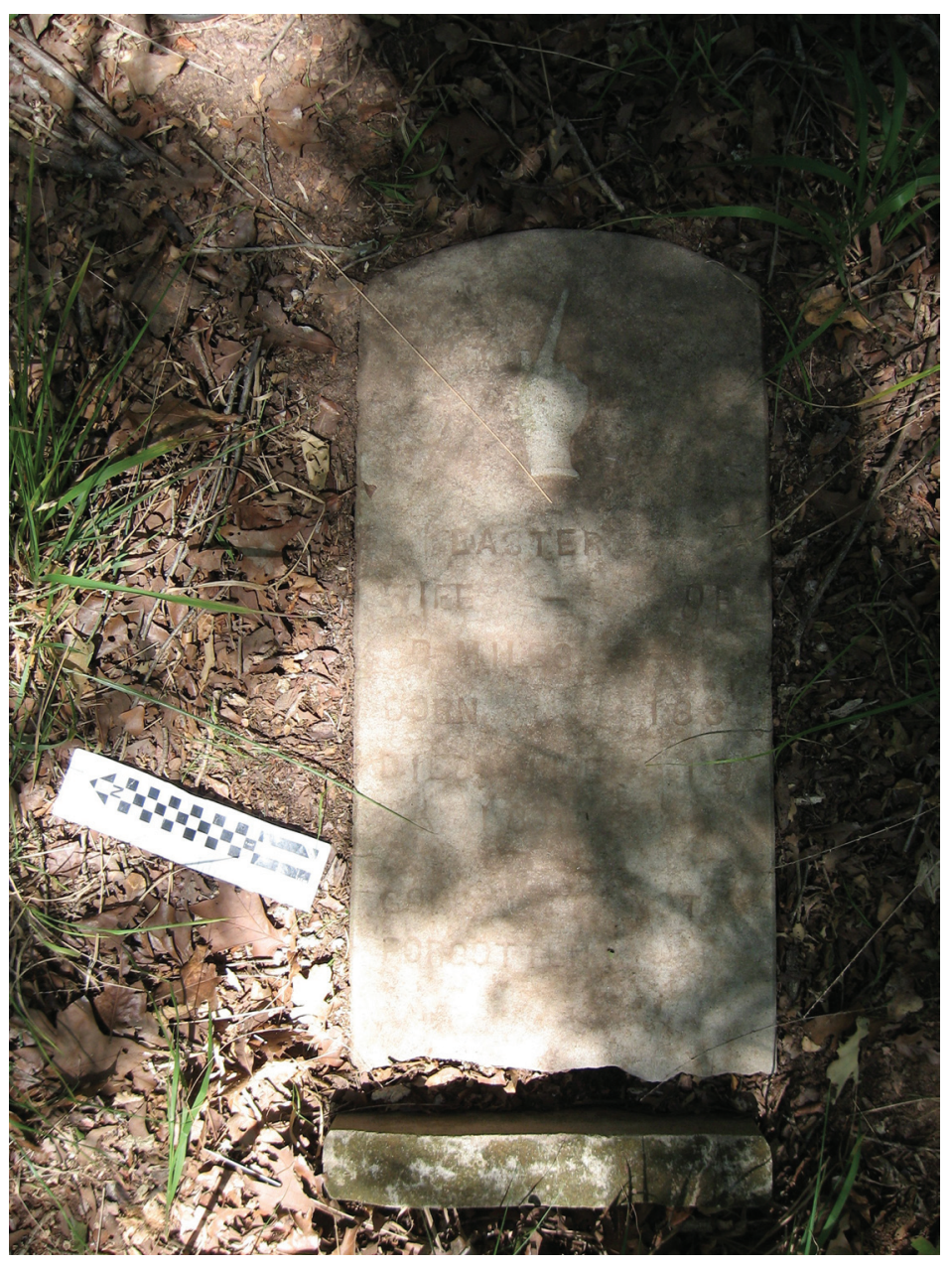

Figure 4-93. Headstone at 41FT630. 


\title{
Chapter 5
}

\section{Management Level and Recommendations}

\author{
David M. Yelacic and Jon C. Lohse
}

\section{Management Level}

As stated in Chapter 3, the 35 sites documented inside the park were graded for management priority on a scale of Level 1 to Level 4, with Level 1 assigned to sites with the highest level of management priority and Level 4 to those with the lowest. The factors that weighed heavily in the decision of management priority level include: the integrity and depth of the sediments if the site was beneath the surface; the amount, distribution, and degree of disturbance of artifacts and features; the amount of modern disturbances; and the geographic and topographic location of the site.

Level 1 sites (41FT280, 41FT408, 41FT409, 41FT470, 41FT481, 41FT482, and 41FT630) are considered to have the highest potential significance in terms of intactness, integrity, and the cultural materials they contain. Level 1 sites are eligible for designations as State Archaeological Landmarks (SALs) or nomination to the National Register of Historic Places (NRHP). CAS recommends that Level 1 sites be avoided during future park developments if at all possible. If these sites cannot be avoided, CAS recommends that additional fieldwork be carried out to offset the resultant loss of information. Such future work should include archaeological testing and, in the case of historic sites, archival research so that the affected site(s) can be contextualized in local, regional, and state historical developments and events.
Level 2 sites (41FT279, 41FT464, 41FT465, 41FT466, 41FT467, 41FT468, 41FT473, 41FT474, 41FT477, 41FT483, and 41FT485) appear to be intact and retain integrity, although for various reasons their potential significance is not fully demonstrated. Therefore, Level 2 sites are of unknown eligibility for designation as SALs or nomination to the NRHP. CAS recommends that if future park developments will impact these sites, additional work should be carried out in advance of those impacts to assess the site's potential significance. In many cases, this additional work might consist merely of archival research (in the case of some historic sites), additional shovel testing, or light, controlled, hand-excavation. Based on this work, recommendations may be made about the need for any additional research to offset the loss of important cultural information that may result from the proposed developments.

Level 3 sites (41FT463, 41FT469, 41FT471, 41FT475, 41FT476, 41FT478, 41FT479, 41FT480, 41FT484, 41FT486, and 41FT488) are considered to have very little to no research potential, but are of unknown eligibility for designation as SALs or nomination to the NRHP for a number of reasons. These include that the sites are on deflated or moderately disturbed landforms, or that they lack an artifact content capable of yielding useful information about historic or prehistoric activities that may have been carried out at these locations. CAS recommends that the THC should review these sites in the event of future impacts. 
An assessment of Level 4 was reserved for sites which had been mostly or completely destroyed by recent development, were significantly impacted by erosion, or were entirely deflated. A small number of sites were classified as Level 4, including 41FT472, 41FT487, 41FT496, 41FT497, 41FT498, and 41FT499. Level 4 sites are considered ineligible for designation as SALs or nomination to the NRHP. The primary distinction between Level 3 and 4 sites is that Level 3 sites, while having low research value, remain present and retain evidence of prehistoric or historic activities that were once carried out there. In contrast, at Level 4 sites, all such integrity and evidence is gone. CAS recommends that TPWD be permitted to develop these areas.

\section{Conclusions/Recommendations}

To summarize, in the event that future park developments will impact the aforementioned cultural resources, CAS offers the following recommendations. Level 1 sites are considered eligible for listing to the NRHP and/or being designated as SALs and should be avoided to the degree possible or feasible in the context of proposed development. If these sites cannot be avoided, CAS recommends that TPWD conduct additional archaeological and, in the case of historic sites, archival research to mitigate the loss of important cultural information that these sites contain. In the event that Level 2 sites cannot be avoided and will be impacted by future developments, CAS recommends that TPWD conduct additional archaeological and/or archival research to finalize assessments about the potential significance of these sites. This research should focus on assessing whether these sites meet any of the significance or worthiness criteria set forth in the NHPA or the Texas Antiquities Code (see Chapter 3, this report). Based on the results of this work, additional research may or may not be warranted. Level 3 sites are considered to have very little to no research potential, but are of unknown eligibility for designation as SALs or nomination to the NRHP. The THC should review these sites in the event of future impacts. Level 4 sites are not considered eligible for listing to the NRHP or worthy of being designated as SALs. If future developments are proposed that will impact Level 4 sites, CAS recommends that TPWD be granted regulatory clearance to proceed with those activities without further consideration for any potential loss of information that may result from that development. A full list of sites and their components and assigned management priority levels can be viewed in Table 5-1.

Additionally, CAS has reason to believe that there may be unrecorded resources within the park. This suspicion is based primarily on three sources. Firstly, Laurie Jasinski's (2002) history of the park mentions structures that do not appear to be associated with any of the recorded archaeological sites. These structures include, among others, a one-room school house/church in the vicinity of Chancellor's Cemetery, and a cistern located near Cook's Ferry Camping Area. Secondly, the USGS quadrangle map of the area (the Young sheet), compiled in 1978 and revised in 1982, depicts a structure in the primitive camping area that, again, does not appear to be associated with any recorded site. Finally, Park Ranger Don Boyd (personal communication 2008) reported finding the remnants of an unrecorded still somewhere in the vicinity of sites 41FT469 and $41 \mathrm{FT} 473$. 
Table 5-1. Sites, their components, and assigned management priority levels.

\begin{tabular}{|c|c|c|c|c|}
\hline \multirow{2}{*}{ Site Trinomial } & \multirow{2}{*}{ Type } & \multicolumn{2}{|c|}{ Component Age } & \multirow{2}{*}{$\begin{array}{c}\text { Management } \\
\text { Priority } \\
\text { (Level)/NRHP } \\
\text { Eligibility }\end{array}$} \\
\hline & & Prehistoric & Historic & \\
\hline 41FT279 & $\begin{array}{l}\text { Historic } \\
\text { Homestead }\end{array}$ & & $\begin{array}{l}\text { Late- } 19^{\text {th }} \text { to } \\
\text { Early } 20^{\text {th }} \\
\text { Century }\end{array}$ & $\begin{array}{l}\text { Moderate to } \\
\text { High (Level 2)/ } \\
\text { Unknown }\end{array}$ \\
\hline 41FT280 & $\begin{array}{l}\text { Historic } \\
\text { Structure }\end{array}$ & & $19^{\text {th }}$ Century & $\begin{array}{c}\text { High (Level 1)/ } \\
\text { Eligible }\end{array}$ \\
\hline 41FT408 & $\begin{array}{l}\text { Historic } \\
\text { Structure }\end{array}$ & & $\begin{array}{c}\text { Late- } 19^{\text {th }} \text { to } 20^{\text {th }} \\
\text { Century }\end{array}$ & $\begin{array}{c}\text { High (Level 1)/ } \\
\text { Eligible }\end{array}$ \\
\hline 41FT409 & Historic Dump & & $\begin{array}{l}\text { Late- } 19^{\text {th }} \text { to } 20^{\text {th }} \\
\text { Century }\end{array}$ & $\begin{array}{c}\text { High (Level 1)/ } \\
\text { Eligible }\end{array}$ \\
\hline 41FT463 & $\begin{array}{l}\text { Prehistoric } \\
\text { Lithic Scatter }\end{array}$ & Unknown & & $\begin{array}{l}\text { Moderate to } \\
\text { Low (Level 3)/ } \\
\text { Unknown }\end{array}$ \\
\hline 41FT464 & $\begin{array}{l}\text { Prehistoric } \\
\text { Campsite }\end{array}$ & $\begin{array}{l}\text { Archaic/Late } \\
\text { Prehistoric }\end{array}$ & & $\begin{array}{l}\text { Moderate to } \\
\text { High (Level 2)/ } \\
\text { Unknown }\end{array}$ \\
\hline 41FT465 & $\begin{array}{l}\text { Prehistoric } \\
\text { Lithic Scatter }\end{array}$ & $\begin{array}{c}\text { Middle/ } \\
\text { Transitional } \\
\text { Archaic }\end{array}$ & & $\begin{array}{l}\text { Moderate to } \\
\text { High (Level 2)/ } \\
\text { Unknown }\end{array}$ \\
\hline 41FT466 & $\begin{array}{l}\text { Prehistoric and } \\
\text { Historic Scatter }\end{array}$ & Unknown & $\begin{array}{l}\text { Early } 20^{\text {th }} \\
\text { Century }\end{array}$ & $\begin{array}{l}\text { Moderate to } \\
\text { High (Level 2)/ } \\
\text { Unknown }\end{array}$ \\
\hline 41FT467 & $\begin{array}{l}\text { Prehistoric } \\
\text { Lithic Scatter }\end{array}$ & Unknown & & $\begin{array}{l}\text { Moderate to } \\
\text { High (Level 2)/ } \\
\text { Unknown }\end{array}$ \\
\hline 41FT468 & $\begin{array}{l}\text { Prehistoric and } \\
\text { Historic Scatter }\end{array}$ & Unknown & $19^{\text {th }}$ Century & $\begin{array}{l}\text { Moderate to } \\
\text { High (Level 2)/ } \\
\text { Unknown }\end{array}$ \\
\hline
\end{tabular}




\begin{tabular}{|c|c|c|c|c|}
\hline 41FT469 & Historic Dump & & $\begin{array}{l}\text { Early- to Mid- } \\
20^{\text {th }} \text { Century }\end{array}$ & $\begin{array}{c}\text { Moderate to } \\
\text { Low (Level 3) } \\
\text { Unknown }\end{array}$ \\
\hline 41FT470 & $\begin{array}{l}\text { Historic } \\
\text { Structure }\end{array}$ & & $\begin{array}{l}\text { Early- to Mid- } \\
20^{\text {th }} \text { Century }\end{array}$ & $\begin{array}{c}\text { High (Level 1) } \\
\text { Eligible }\end{array}$ \\
\hline 41FT471 & $\begin{array}{c}\text { Prehistoric } \\
\text { Lithic Scatter } \\
\text { (Isolated Find) }\end{array}$ & Unknown & & $\begin{array}{c}\text { Moderate to } \\
\text { Low (Level 3) } \\
\text { Unknown }\end{array}$ \\
\hline $41 \mathrm{FT} 472$ & $\begin{array}{c}\text { Prehistoric } \\
\text { Lithic Scatter/ } \\
\text { Historic Dump }\end{array}$ & Unknown & $\begin{array}{l}\text { Late-19 } 9^{\text {th }} \text { to } \\
\text { Early-20 } \\
\text { Century }\end{array}$ & $\begin{array}{c}\text { Low (Level 4) } \\
\text { Ineligible }\end{array}$ \\
\hline 41 FT473 & $\begin{array}{l}\text { Prehistoric } \\
\text { Lithic Scatter }\end{array}$ & Unknown & & $\begin{array}{c}\text { Moderate to } \\
\text { High (Level 2) } \\
\text { Unknown }\end{array}$ \\
\hline 41 FT474 & $\begin{array}{c}\text { Historic } \\
\text { Special-Use }\end{array}$ & & $\begin{array}{l}\text { Early- to Mid- } \\
20^{\text {th }} \text { Century }\end{array}$ & $\begin{array}{l}\text { Moderate to } \\
\text { High (Level 2) } \\
\text { Unknown }\end{array}$ \\
\hline $41 \mathrm{FT} 475$ & Historic Dump & & $20^{\text {th }}$ Century & $\begin{array}{l}\text { Moderate to } \\
\text { Low (Level 3) } \\
\text { Unknown }\end{array}$ \\
\hline 41FT476 & $\begin{array}{c}\text { Prehistoric } \\
\text { Lithic Scatter }\end{array}$ & Unknown & & $\begin{array}{c}\text { Moderate to } \\
\text { Low (Level 3) } \\
\text { Unknown }\end{array}$ \\
\hline 41 FT477 & $\begin{array}{l}\text { Possible } \\
\text { Historic } \\
\text { Structure }\end{array}$ & & $\begin{array}{l}\text { Early-20 } 0^{\text {th }} \\
\text { Century }\end{array}$ & $\begin{array}{c}\text { Moderate to } \\
\text { High (Level 2) } \\
\text { Unknown }\end{array}$ \\
\hline 41FT478 & $\begin{array}{c}\text { Prehistoric } \\
\text { Lithic Scatter } \\
\text { (Isolated Find) }\end{array}$ & Unknown & & $\begin{array}{c}\text { Moderate to } \\
\text { Low (Level 3) } \\
\text { Unknown }\end{array}$ \\
\hline 41 FT479 & $\begin{array}{l}\text { Prehistoric } \\
\text { Lithic Scatter }\end{array}$ & Unknown & & $\begin{array}{c}\text { Moderate to } \\
\text { Low (Level 3) } \\
\text { Unknown }\end{array}$ \\
\hline 41FT480 & $\begin{array}{l}\text { Prehistoric } \\
\text { Lithic Scatter }\end{array}$ & Unknown & & $\begin{array}{l}\text { Moderate to } \\
\text { Low (Level 3) } \\
\text { Unknown }\end{array}$ \\
\hline
\end{tabular}




\begin{tabular}{|c|c|c|c|c|}
\hline 41FT481 & $\begin{array}{l}\text { Possible } \\
\text { Historic } \\
\text { Structure }\end{array}$ & & $\begin{array}{l}\text { Late-19 }{ }^{\text {th }} \text { to } \\
\text { Early-20 } 20^{\text {th }} \\
\text { Century }\end{array}$ & $\begin{array}{c}\text { High (Level 1) } \\
\text { Eligible }\end{array}$ \\
\hline 41FT482 & $\begin{array}{l}\text { Historic } \\
\text { Structure }\end{array}$ & & $\begin{array}{l}\text { Early- to Mid- } \\
20^{\text {th }} \text { Century }\end{array}$ & $\begin{array}{c}\text { High (Level 1) } \\
\text { Eligible }\end{array}$ \\
\hline 41FT483 & $\begin{array}{l}\text { Prehistoric } \\
\text { Campsite }\end{array}$ & $\begin{array}{l}\text { Archaic/Late } \\
\text { Prehistoric }\end{array}$ & & $\begin{array}{l}\text { Moderate to } \\
\text { High (Level 2) } \\
\text { Unknown }\end{array}$ \\
\hline 41FT484 & $\begin{array}{l}\text { Prehistoric } \\
\text { Campsite }\end{array}$ & Unknown & & $\begin{array}{c}\text { Moderate to } \\
\text { Low (Level 3)/ } \\
\text { Unknown }\end{array}$ \\
\hline 41FT485 & $\begin{array}{l}\text { Possible } \\
\text { Historic } \\
\text { Structure }\end{array}$ & & $\begin{array}{l}\text { Late-19 }{ }^{\text {th }} \text { to } \\
\text { Early- } 20^{\text {th }} \\
\text { Century }\end{array}$ & $\begin{array}{c}\text { Moderate to } \\
\text { High (Level 2) } \\
\text { Unknown }\end{array}$ \\
\hline 41FT486 & $\begin{array}{c}\text { Historic } \\
\text { Homestead/ } \\
\text { Farmstead }\end{array}$ & & $20^{\text {th }}$ Century & $\begin{array}{c}\text { Moderate to } \\
\text { Low (Level 3)/ } \\
\text { Unknown }\end{array}$ \\
\hline 41FT487 & $\begin{array}{l}\text { Possible } \\
\text { Historic } \\
\text { Structure }\end{array}$ & & $\begin{array}{l}\text { Late-19 } 19^{\text {th }} \text { to } \\
\text { Early- } 20^{\text {th }} \\
\text { Century }\end{array}$ & $\begin{array}{c}\text { Low (Level 4)/ } \\
\text { Ineligible }\end{array}$ \\
\hline 41FT488 & $\begin{array}{l}\text { Prehistoric } \\
\text { Lithic Scatter }\end{array}$ & Unknown & & $\begin{array}{c}\text { Moderate to } \\
\text { Low (Level 3)/ } \\
\text { Unknown }\end{array}$ \\
\hline 41FT496 & $\begin{array}{c}\text { Prehistoric } \\
\text { Lithic Scatter } \\
\text { (Isolated Find) }\end{array}$ & Unknown & & $\begin{array}{c}\text { Low (Level 4)/ } \\
\text { Ineligible }\end{array}$ \\
\hline 41FT497 & Unknown & Unknown & Unknown & $\begin{array}{c}\text { Low (Level 4)/ } \\
\text { Ineligible }\end{array}$ \\
\hline 41FT498 & $\begin{array}{c}\text { Prehistoric } \\
\text { Lithic Scatter } \\
\text { (Isolated Find) }\end{array}$ & Unknown & & $\begin{array}{c}\text { Low (Level 4)/ } \\
\text { Ineligible }\end{array}$ \\
\hline 41FT499 & $\begin{array}{l}\text { Unknown } \\
\text { Historic }\end{array}$ & & Unknown & $\begin{array}{c}\text { Low (Level 4)/ } \\
\text { Ineligible }\end{array}$ \\
\hline
\end{tabular}




\begin{tabular}{|c|c|c|c|c|}
\hline $41 \mathrm{FT} 630$ & $\begin{array}{c}\text { Historic } \\
\text { Cemetery }\end{array}$ & & 19th Century & $\begin{array}{c}\text { High (Level 1)/ } \\
\text { Eligible }\end{array}$ \\
\hline
\end{tabular}




\section{References Cited}

Barber, Edwin A.

2001 Marks of American Potters. The Blackburn Press, Caldwell, New Jersey.

Bruseth, James E., and Randall W. Moir (editors)

1987 Introduction to the Richland Creek Archaeological Project: Environmental Background and Cultural Setting. Richland Creek Archaeological Project, Vol. 1. Richland Creek Technical Series, Archaeology Research Program, Institute for the Study of Earth and Man, Southern Methodist University, Texas.

Cook, Scott

1998 Mexican Brick Culture in the Building of Texas, 1800s-1980s. Texas A\&M University Press, College Station.

Crouch, Dan

1992 Site 41FT279 site data. Records on file with the Texas Historical Commission, Texas Archeological Site Atlas. Electronic document, http://www.nueces.thc.state.tx.us, accessed on May 20, 2008.

1992 Site 41FT280 site data. Records on file with the Texas Historical Commission, Texas Archeological Site Atlas. Electronic document, http://www.nueces.thc.state.tx.us, accessed on May 20, 2008.

Fields, Ross C.

1995 The Archaeology of the Post Oak Savannah of East Central Texas. Bulletin of the Texas Archeological Society, Vol. 66:301-330.

2004 The Archaeology of the Post Oak Savanna of East-Central Texas. The Prehistory of Texas (edited by Timothy K. Perttula). Texas A\&M University Press, College Station.

Fields, Ross C., Eloise F. Gadus, Amy C. Earls, Karen M. Gardner, L. Wayne Klement, and Janet K. Wagner

1995 National Register Assessments of Prehistoric and Historic Sites in Area E at the Jewett Mine, Freestone County, Texas. Reports of Investigations, Number 100. Prewitt and Associates, Inc. Consulting Archeologists, Austin, Texas.

Greer, Georgeanna H.

2005 American Stonewares: The Art and Craft of Utilitarian Potters. 4th edition. Schiffer Publishing, Atglen, Pennsylvania. 
Griffith, G.E., S.A. Bryce, J.M. Omernik, J.A. Comstock, A.C. Rogers, B. Harrison, S.L. Hatch, and D. Bezanson

2004 Ecoregions of Texas. U.S. Environmental Protection Agency, Corvallis, Oregon.

Hume, Ivor Noel

1969 A Guide to Artifacts of Colonial America. Vintage Books, New York.

Janak, Edward F., and Edward L. Griffin

2002 Soil Survey of Freestone County, Texas. United States Department of Agriculture, Natural Resources Conservation Service and Texas Agriculture Experiment Station, College Station.

Jasinski, Laurie E

2002 Land of Great Promise: A History of Fairfield Lake State Park. Texas Parks and Wildlife Cultural Resources Program, Austin, Texas.

Ketchum, William C.

2000 American Pottery and Porcelain. Black Dog and Leventhal, New York.

Lindsey, Bill

2008 Historic Glass Bottle Identification and Information Website. Electronic document. URL: http://www.sha.org/bottle/index.htm, accessed July 2008.

Meltzer, David J., and Michael R. Bever

1995 Paleoindians of Texas: An Update on the Texas Clovis Fluted Point Survey. Bulletin of the Texas Archeological Society, Vol. 66:47-81.

Miller, G. L.

1993 A User's Guide to Ceramic Assemblages, Part Four: Some Thoughts on Classification of White Earthwares. Council for Northwest Historical Archaeology Newsletter, No.26.

Munsey, Cecil

1970 The Illustrated Guide to Collecting Bottles. Hawthorn Books, New York.

Perttula, Timothy K.

1990 The Hurricane Hill Site (41HP106): Excavations at Cooper Lake, Hopkins County, Texas. Second Draft. Contributions in Archaeology No. 9. Institute of Applied Sciences, University of North Texas, Denton.

1995 The Archeology of the Pineywoods and Post Oak Savanna of Northeast Texas. Bulletin of the Texas Archeological Society, Vol. 66:331-359.

2004 The Prehistoric and Caddoan Archeology of the Northeastern Texas Pineywoods. The Prehistory of Texas. Texas A\&M University Press, College Station. 
Ralph, Ronald William

1997 Site 41FT408 site data. Records on file with the Texas Historical Commission, Texas Archeological Site Atlas. Electronic document, http://www.nueces.thc.state.tx.us, accessed on May 20, 2008.

1997 Site 41FT409 site data. Records on file with the Texas Historical Commission, Texas Archeological Site Atlas. Electronic document, http://www.nueces.thc.state.tx.us, accessed on May 20, 2008.

Richner, Jeffrey J.

1982 Tennessee Colony III. Archaeology Research Program, Department of Anthropology, Southern Methodist University, Dallas.

Richner, Jeffrey J., and Joe T. Bagot

1978 A Reconnaissance Survey of the Trinity River Basin. Archaeology Research Program Research Report 113. Archaeology Research Program, Department of Anthropology, Southern Methodist University, Dallas.

Steinbomer, R. A.

1982 Brickmaking in Texas: A History of the Industry and its Product. Unpublished manuscript submitted to the Texas Historical Commission, Austin.

Story, Dee Ann

1965 The Archeology of Cedar Creek Reservoir, Henderson and Kaufman Counties, Texas. Bulletin of the Texas Archeological Society, Vol. 36:163-257.

1990 Cultural History of the Native Americans. The Archaeology of the Gulf Coastal Plain: Vol. 1:163-366. Arkansas Archaeological Survey Research Series No. 38.

Toulouse, Julian Harrison

1971 Bottle Makers and Their Marks. The Blackburn Press, Caldwell, New Jersey.

Turner, Ellen Sue, and Thomas R. Hester

1999 A Field Guide to Stone Artifacts of Texas Indians. Gulf Publishing, Landham, Maryland.

Wenke, Robert J.

1990 Patterns in Prehistory: Humankind's First Three Million Years. $3^{\text {rd }}$ ed. Oxford University Press, Oxford, England.

Westmorland Coal Company

2008 General information on Jewett Mine. Electronic Document. URL: http://www.westmoreland. com/coal.asp?topoc=westmoreland_mining, accessed on May 22, 2008 


\section{ApPendix A}

\section{Fairfield Lake State Park - TPWD \\ 41FT279 Shovel Test No. 1}

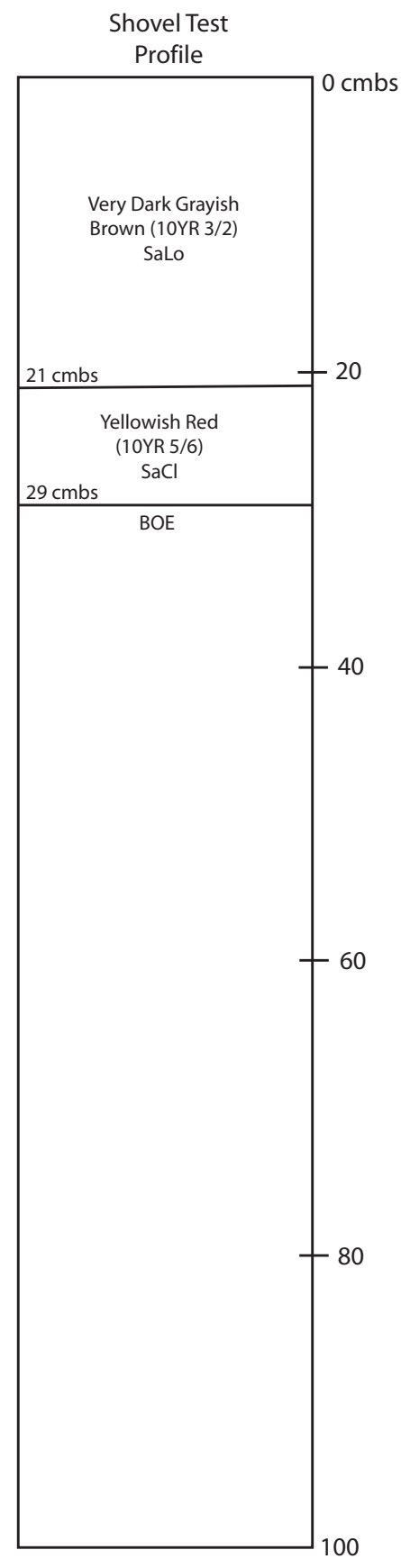

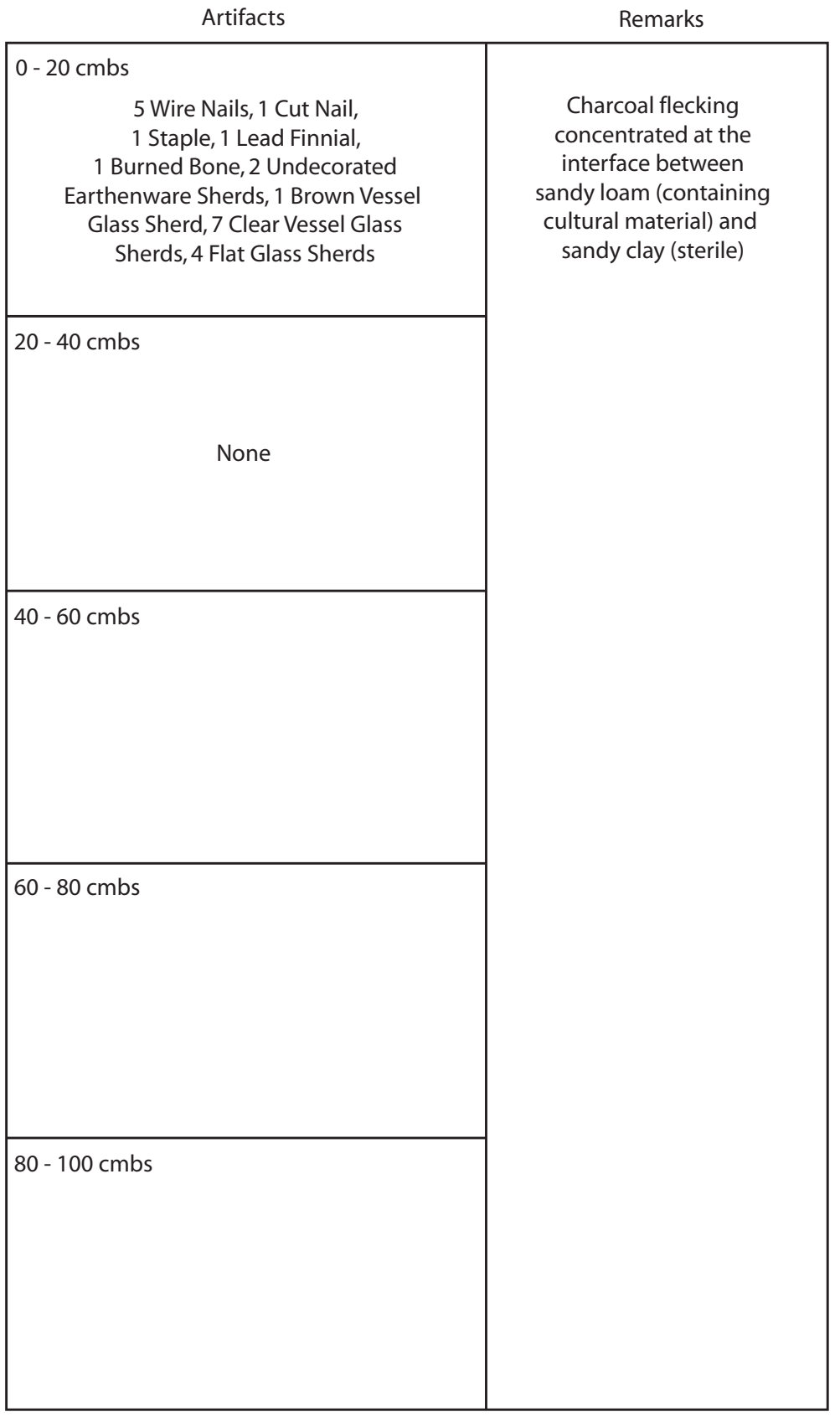




\section{Fairfield Lake State Park - TPWD \\ 41FT279 Shovel Test No. 2}

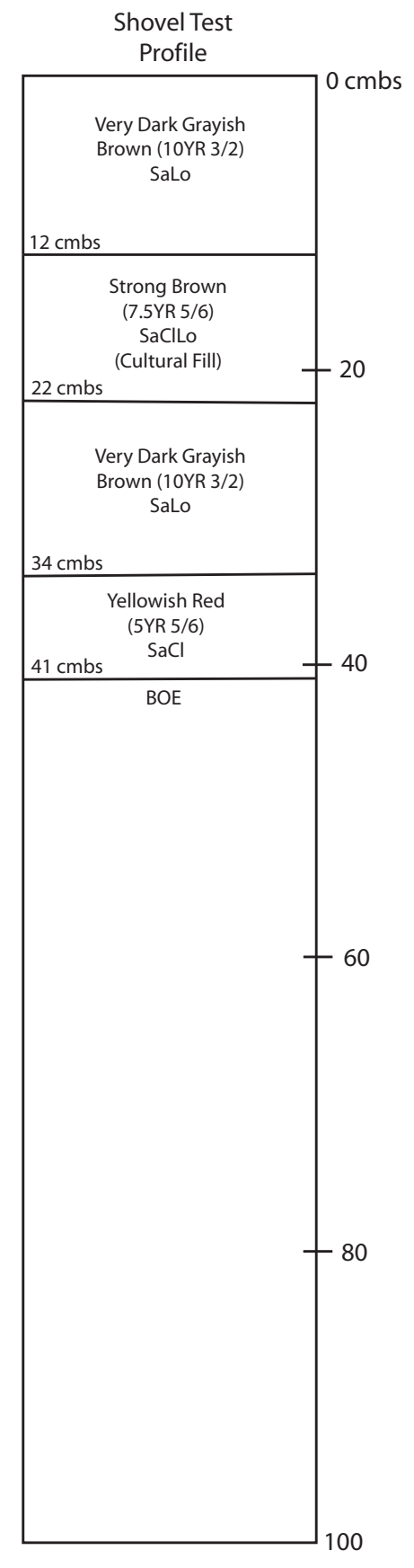

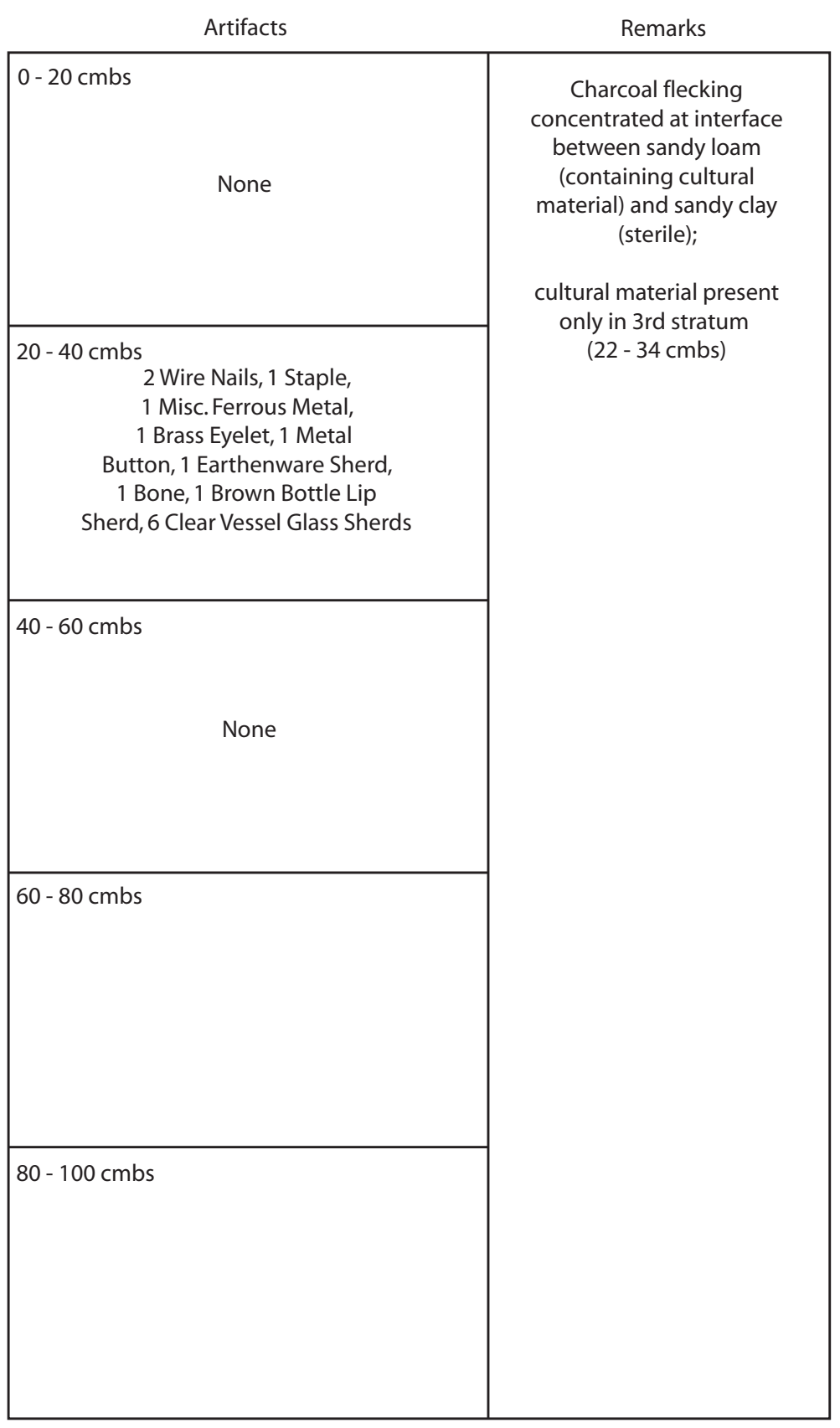


Fairfield Lake State Park - TPWD

41FT279 Shovel Test No. 3

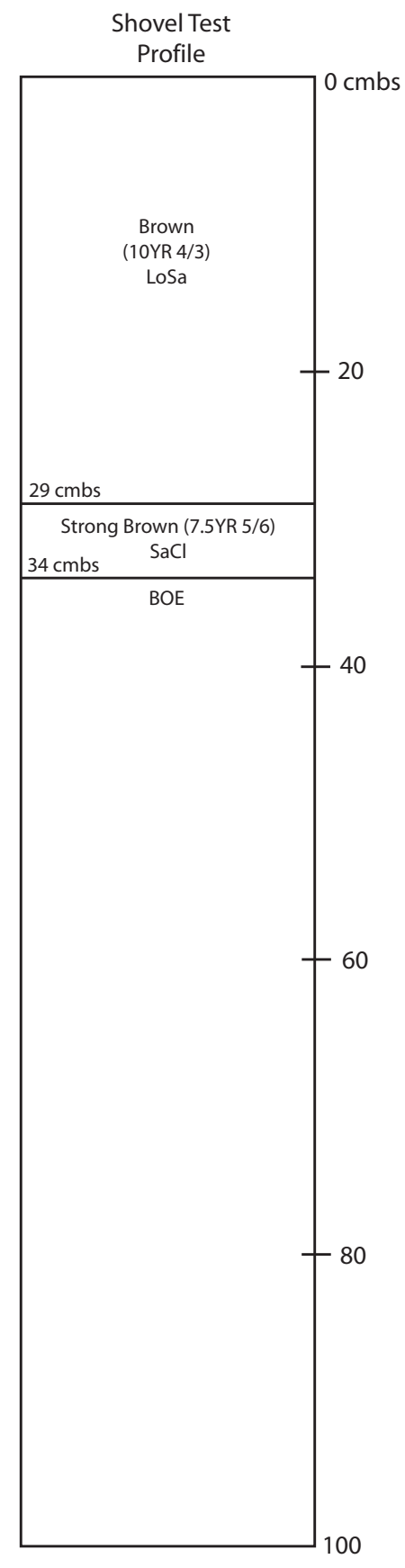

\begin{tabular}{|c|c|}
\hline Artifacts & Remarks \\
\hline $\begin{array}{l}0-20 \text { cmbs } \\
\\
1 \text { Earthenware Sherd, } \\
1 \text { Clear Vessel Glass Sherd }\end{array}$ & None \\
\hline 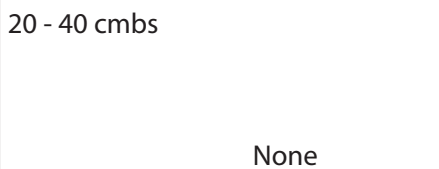 & \\
\hline $40-60 \mathrm{cmbs}$ & \\
\hline $60-80 \mathrm{cmbs}$ & \\
\hline $80-100 \mathrm{cmbs}$ & \\
\hline
\end{tabular}




\section{Fairfield Lake State Park - TPWD}

41FT279 Shovel Test No. 5

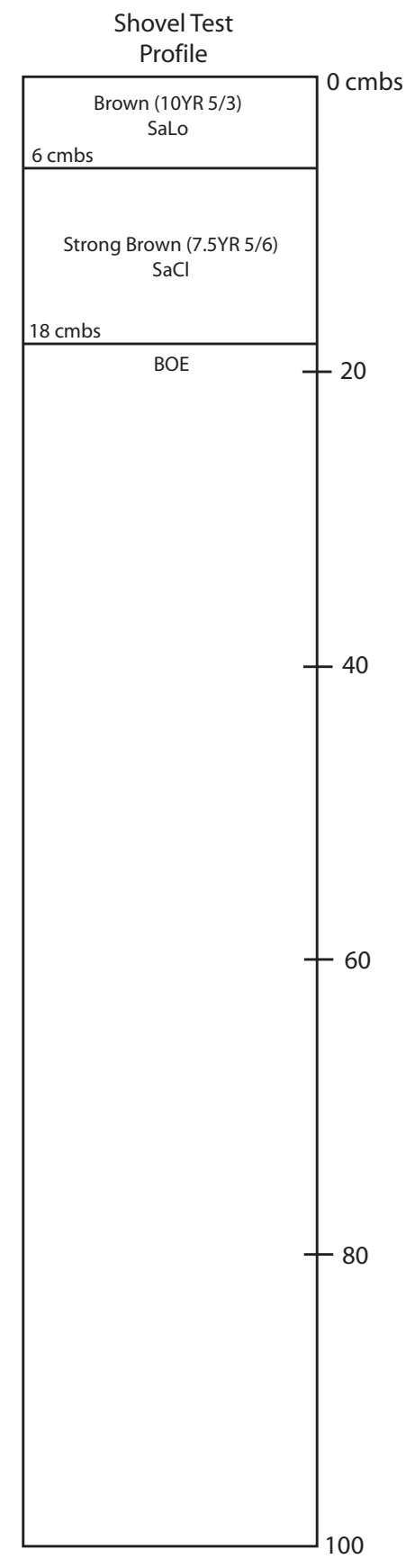

\begin{tabular}{|c|c|}
\hline Artifacts & Remarks \\
\hline $\begin{array}{l}0-20 \mathrm{cmbs} \\
\quad 2 \text { Wire Nails, } 1 \text { Earthenware Sherd }\end{array}$ & $\begin{array}{l}\text { Cultural materials present } \\
\text { only in } 1 \mathrm{st} \text { stratum } \\
(0-6 \mathrm{cmbs})\end{array}$ \\
\hline $20-40 \mathrm{cmbs}$ & \\
\hline $40-60 \mathrm{cmbs}$ & \\
\hline $60-80 \mathrm{cmbs}$ & \\
\hline $80-100 \mathrm{cmbs}$ & \\
\hline
\end{tabular}


Fairfield Lake State Park - TPWD

41FT280 Shovel Test No. 1

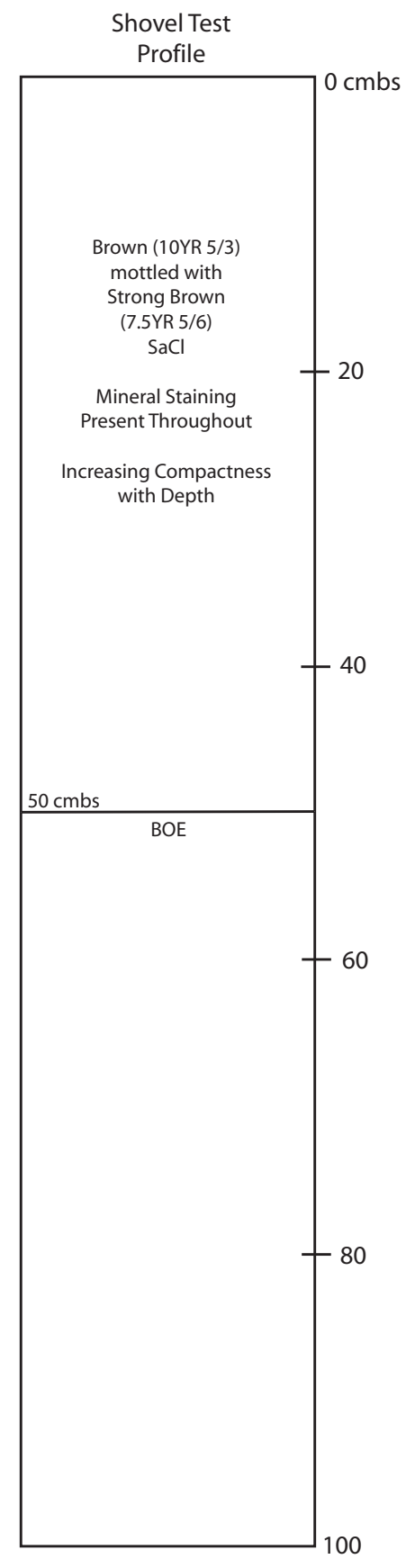

\begin{tabular}{|c|c|}
\hline Artifacts & Remarks \\
\hline $0-20 \mathrm{cmbs}$ & $\begin{array}{c}\text { Located in center of } \\
2.5 \text { m square cultural } \\
\text { depression; } \\
3 \text { total brick } \\
\text { fragments found in } \\
\text { the shovel test } \\
\text { profile ( } 15-25 \mathrm{cmbs} \text { ) }\end{array}$ \\
\hline $\begin{array}{l}20-40 \text { cmbs } \\
\text { Brick Fragments }\end{array}$ & \\
\hline 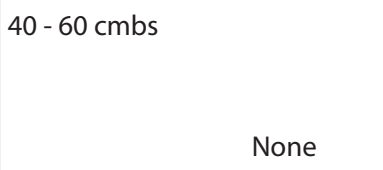 & \\
\hline $60-80 \mathrm{cmbs}$ & \\
\hline $80-100 \mathrm{cmbs}$ & \\
\hline
\end{tabular}




\section{Fairfield Lake State Park - TPWD \\ 41FT280 Shovel Test No. 2}

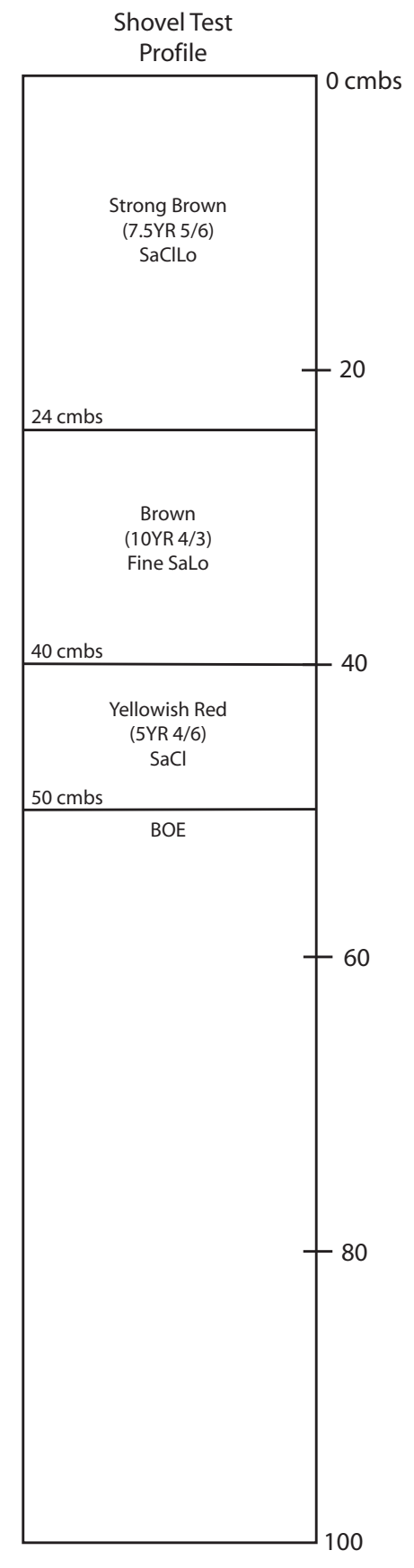

\begin{tabular}{|c|c|}
\hline Artifacts & Remarks \\
\hline $0-20 \mathrm{cmbs}$ & $\begin{array}{l}\text { Located on spoil } \\
\text { pile adjacent to } 2.5 \mathrm{~m} \\
\text { square depression; } \\
\text { distinct boundary between } \\
\text { overburden (SaClLo) and } \\
\text { buried topsoil (Fine SaLo); }\end{array}$ \\
\hline $\begin{array}{l}20-40 \text { cmbs } \\
\text { 3 Cut Nails, } \\
1 \text { Brass Buckle Fragment }\end{array}$ & $\begin{array}{l}\text { only in } 2 \text { nd stratum } \\
(24-40 \mathrm{cmbs})\end{array}$ \\
\hline 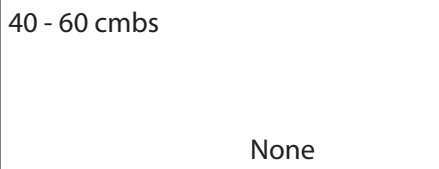 & \\
\hline $60-80 \mathrm{cmbs}$ & \\
\hline $80-100 \mathrm{cmbs}$ & \\
\hline
\end{tabular}


Fairfield Lake State Park - TPWD

41FT464 Shovel Test No. 1

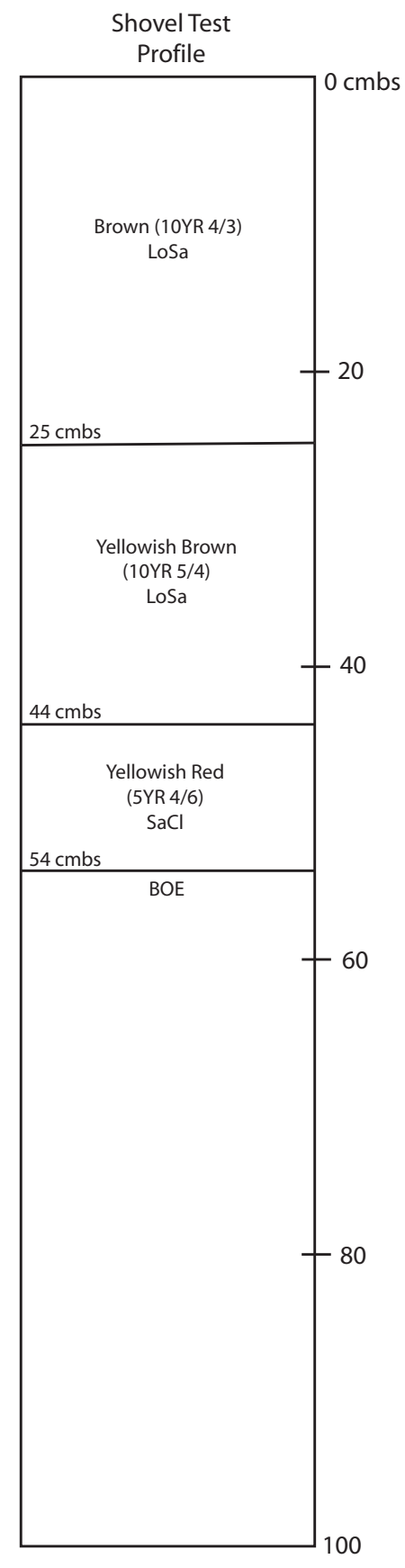

\begin{tabular}{|c|c|}
\hline Artifacts & Remarks \\
\hline $\begin{array}{l}0-20 \text { cmbs } \\
\\
1 \text { Interior Chert Flake, } \\
1 \text { Probable Fire Cracked Rock }\end{array}$ & None \\
\hline 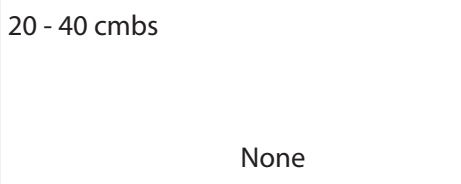 & \\
\hline 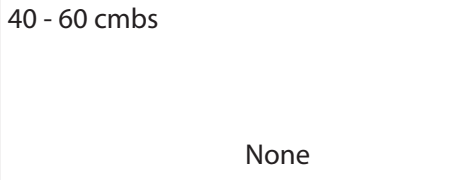 & \\
\hline $60-80 \mathrm{cmbs}$ & \\
\hline $80-100 \mathrm{cmbs}$ & \\
\hline
\end{tabular}




\section{Fairfield Lake State Park - TPWD \\ 41FT468 Shovel Test No. 1}

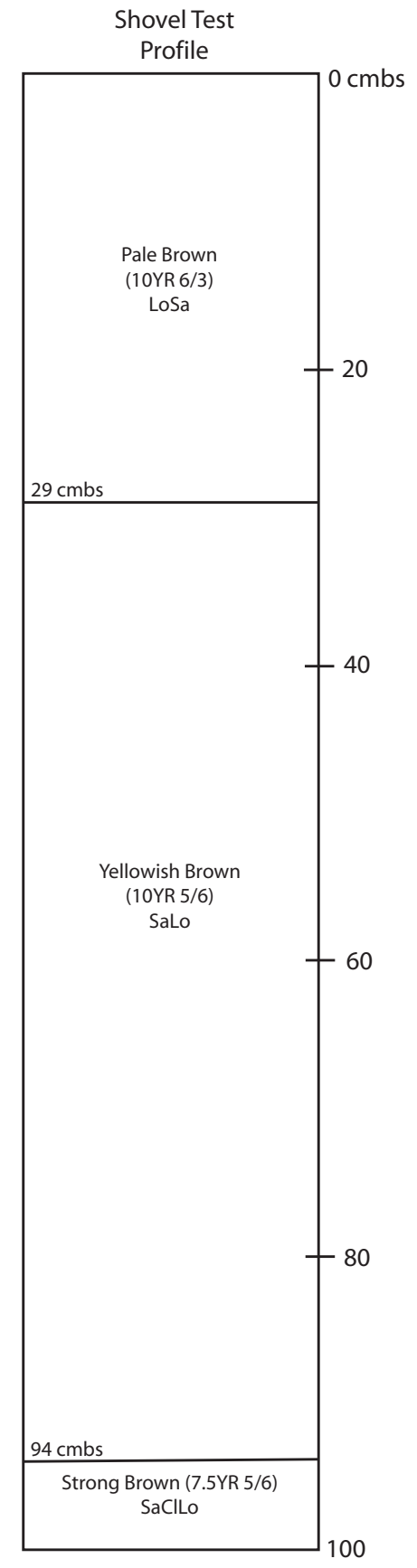

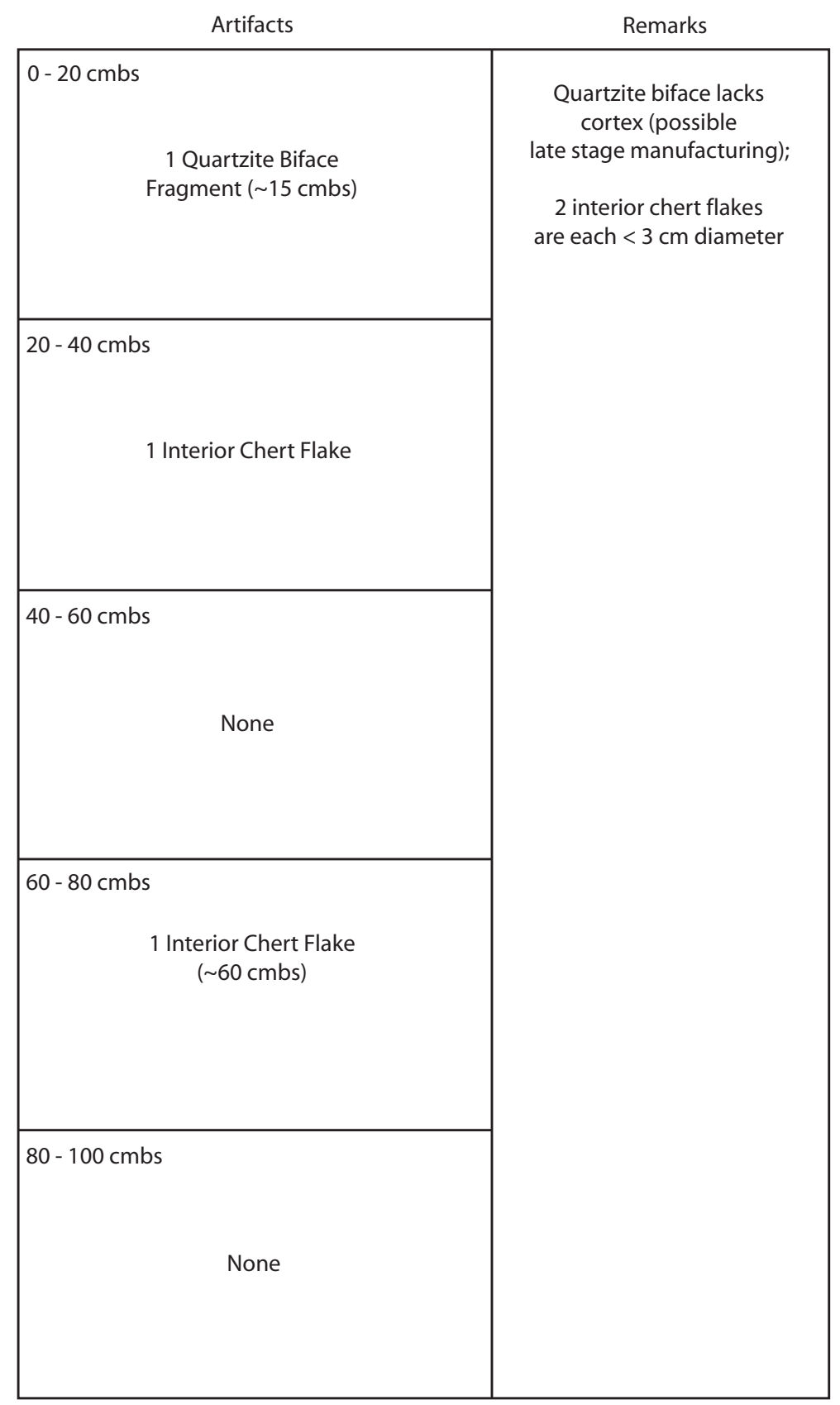


Fairfield Lake State Park - TPWD

41FT470 Shovel Test No. 3

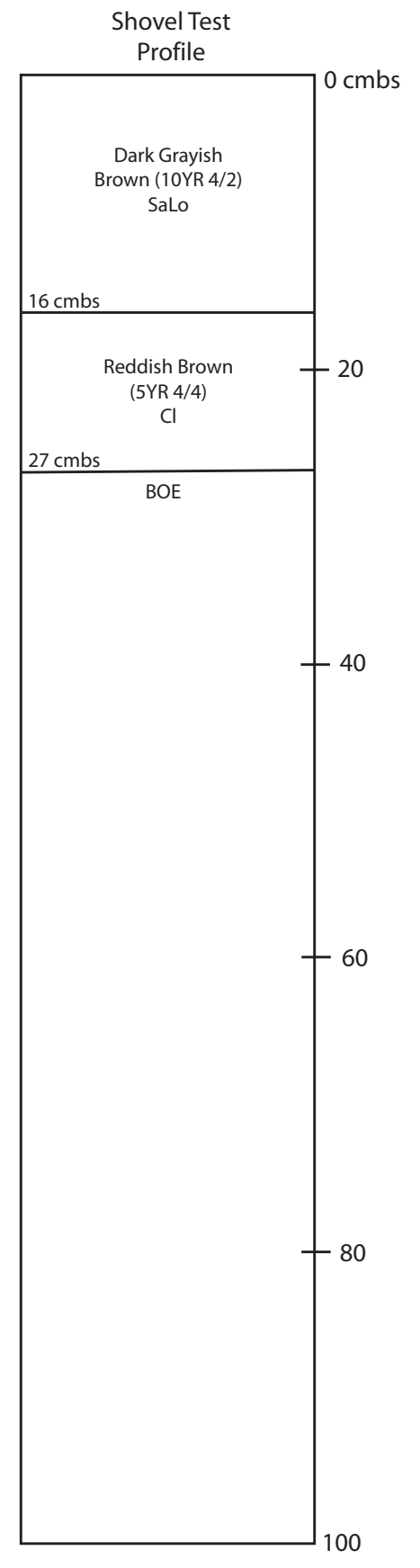

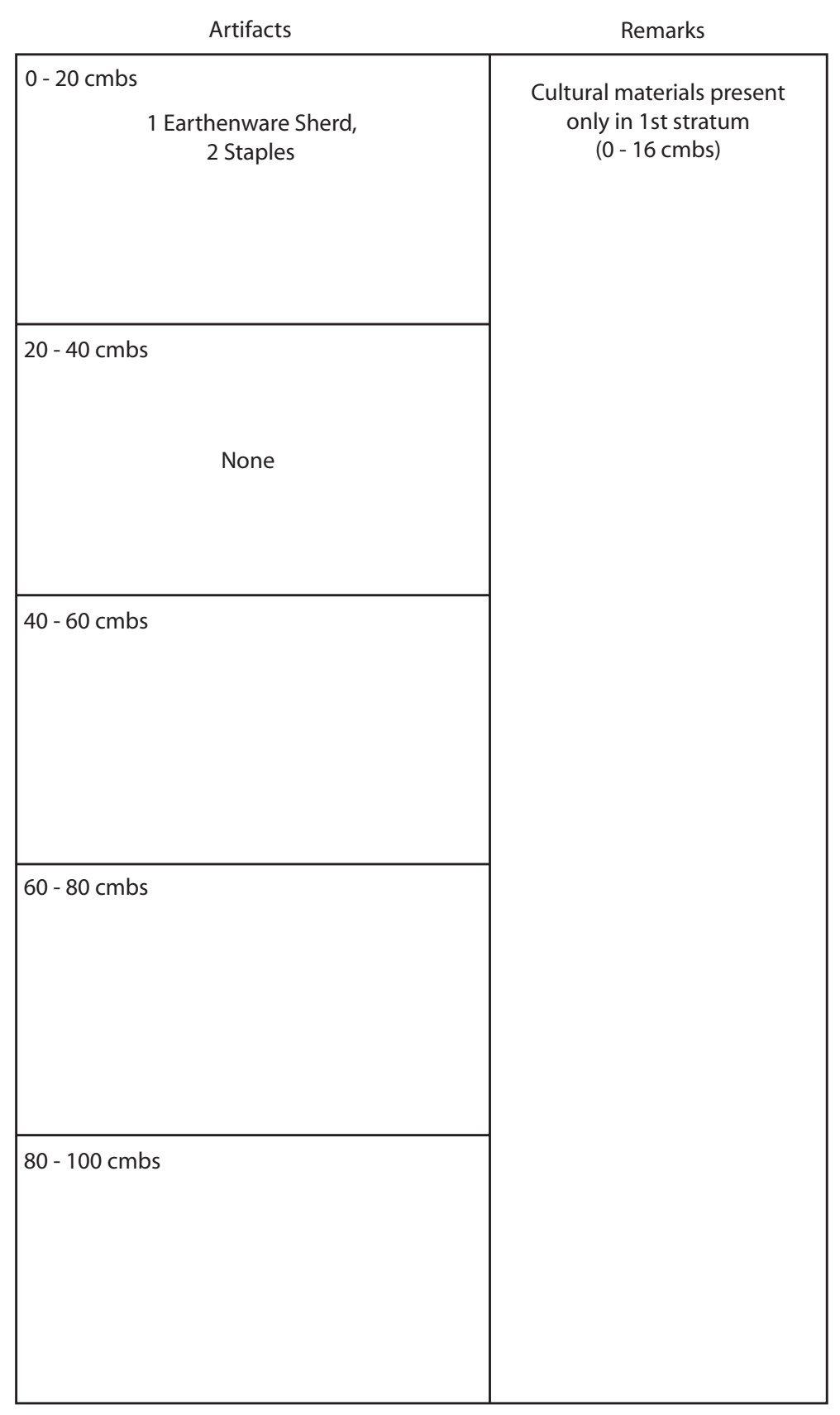


Fairfield Lake State Park - TPWD

41FT473 Shovel Test No. 1

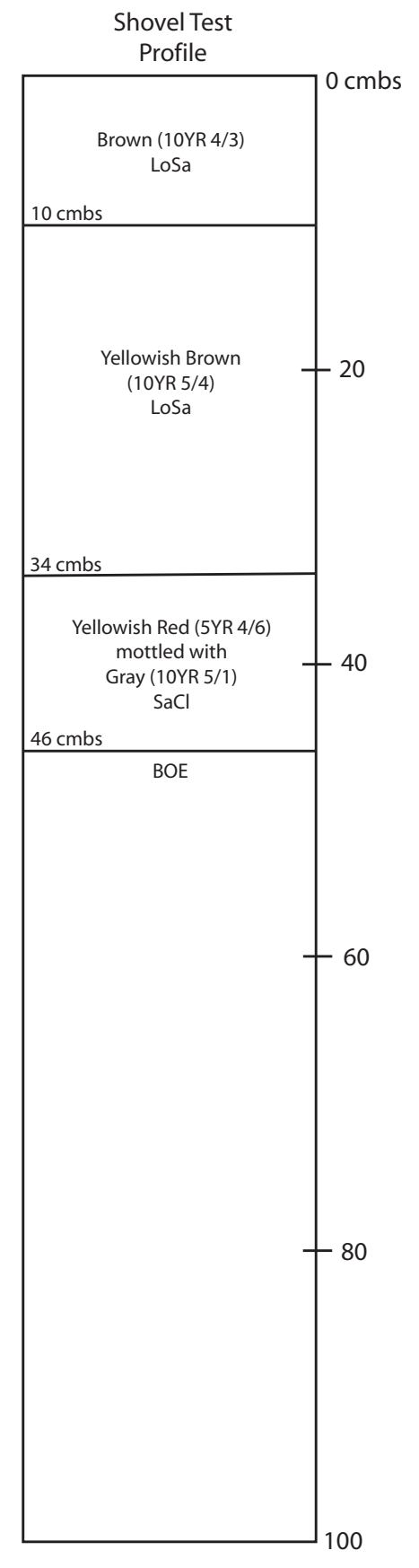

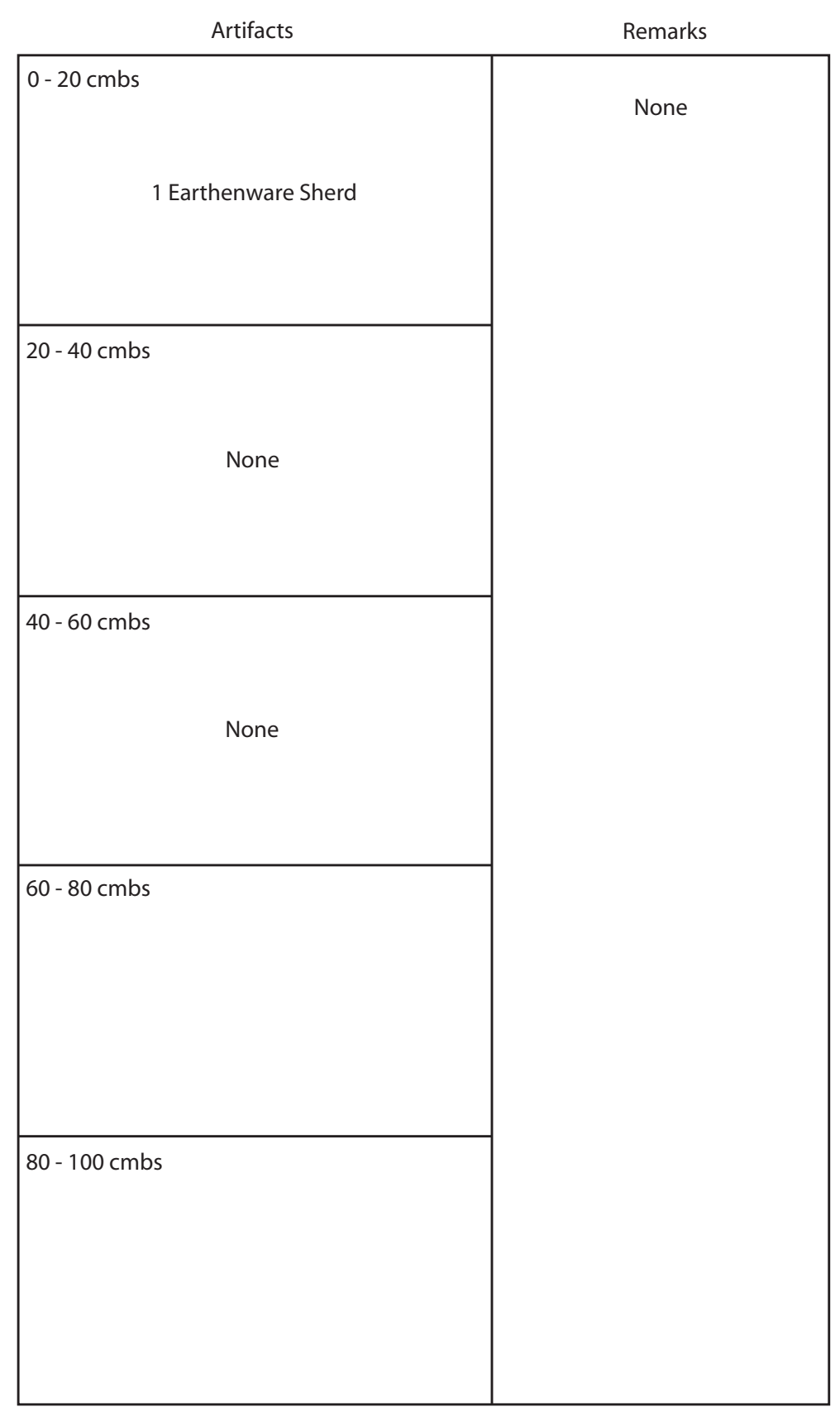


Fairfield Lake State Park - TPWD

41FT482 Shovel Test No. 2

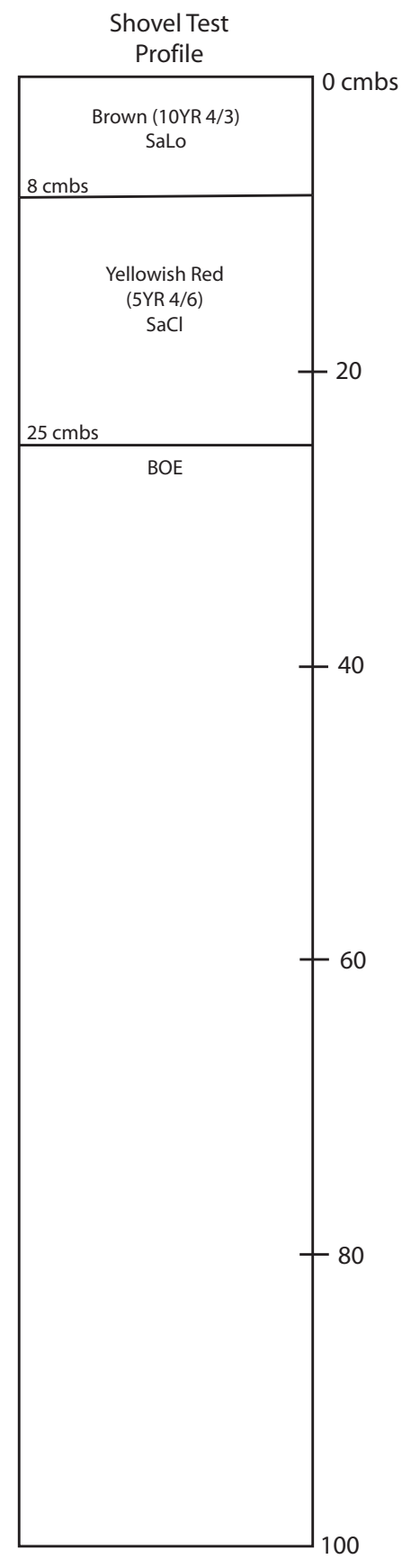

\begin{tabular}{|c|c|}
\hline Artifacts & Remarks \\
\hline $\begin{array}{l}0-20 \mathrm{cmbs} \\
\\
1 \text { Decorated } \\
\text { Earthenware Sherd }\end{array}$ & $\begin{array}{l}\text { Cultural material present } \\
\text { only in } 2 \text { nd stratum } \\
\text { (8 - } 25 \mathrm{cmbs})\end{array}$ \\
\hline $20-40 \mathrm{cmbs}$ & \\
\hline $40-60 \mathrm{cmbs}$ & \\
\hline $60-80 \mathrm{cmbs}$ & \\
\hline $80-100 \mathrm{cmbs}$ & \\
\hline
\end{tabular}


Fairfield Lake State Park - TPWD

41FT482 Shovel Test No. 4

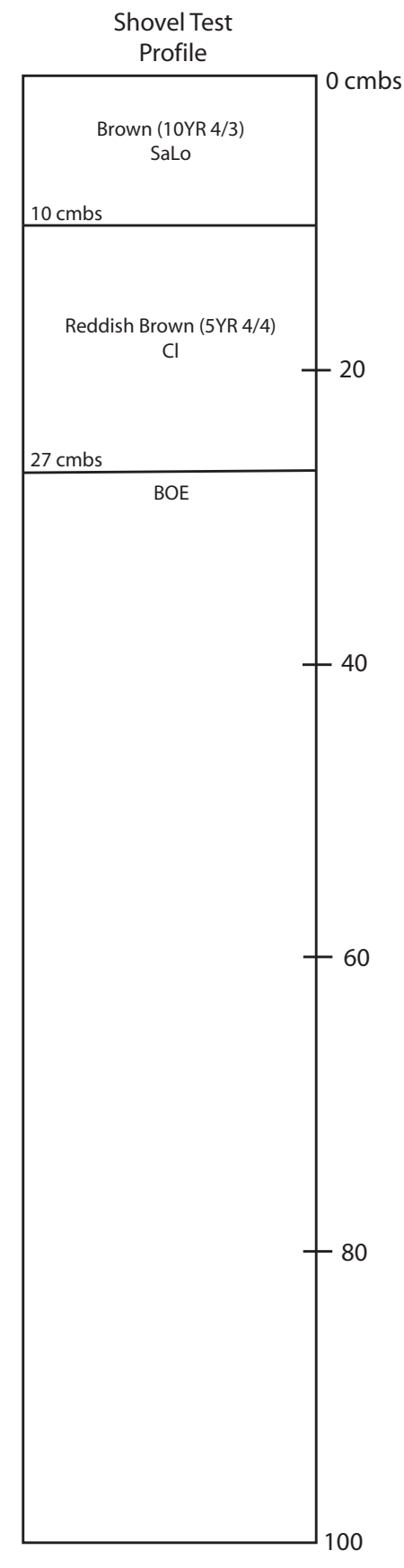

\begin{tabular}{|c|c|}
\hline Artifacts & Remarks \\
\hline $\begin{array}{l}0-20 \mathrm{cmbs} \\
\\
1 \text { Brown Bottle Glass Sherd }\end{array}$ & $\begin{array}{l}\text { Cultural material present } \\
\text { only in } 1 \mathrm{st} \text { stratum } \\
(0-10 \mathrm{cmbs})\end{array}$ \\
\hline $20-40 \mathrm{cmbs}$ & \\
\hline $40-60 \mathrm{cmbs}$ & \\
\hline $60-80 \mathrm{cmbs}$ & \\
\hline $80-100 \mathrm{cmbs}$ & \\
\hline
\end{tabular}


Fairfield Lake State Park - TPWD

41FT482 Shovel Test No. 5

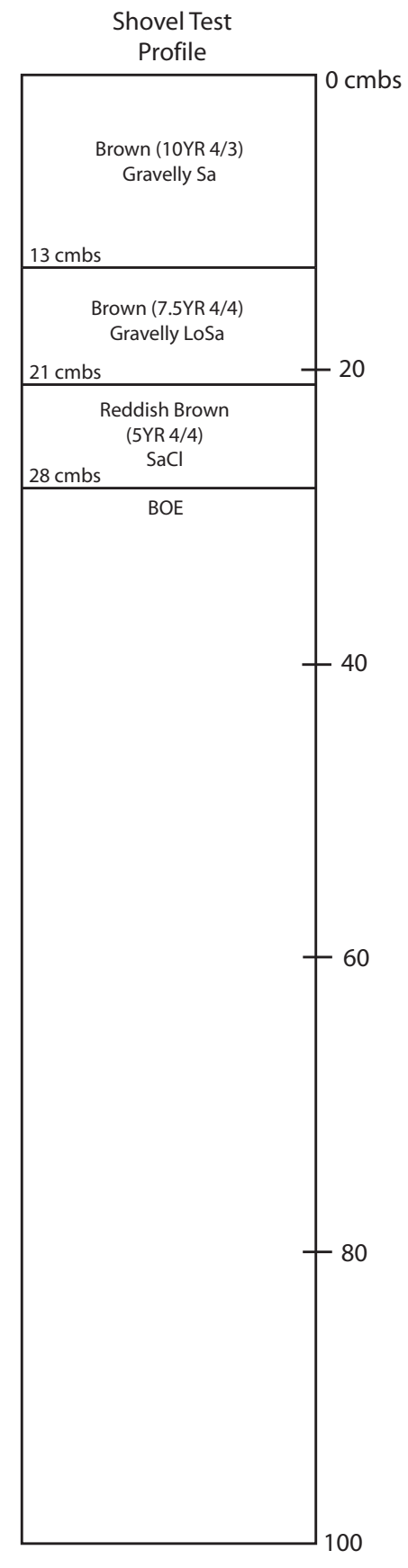

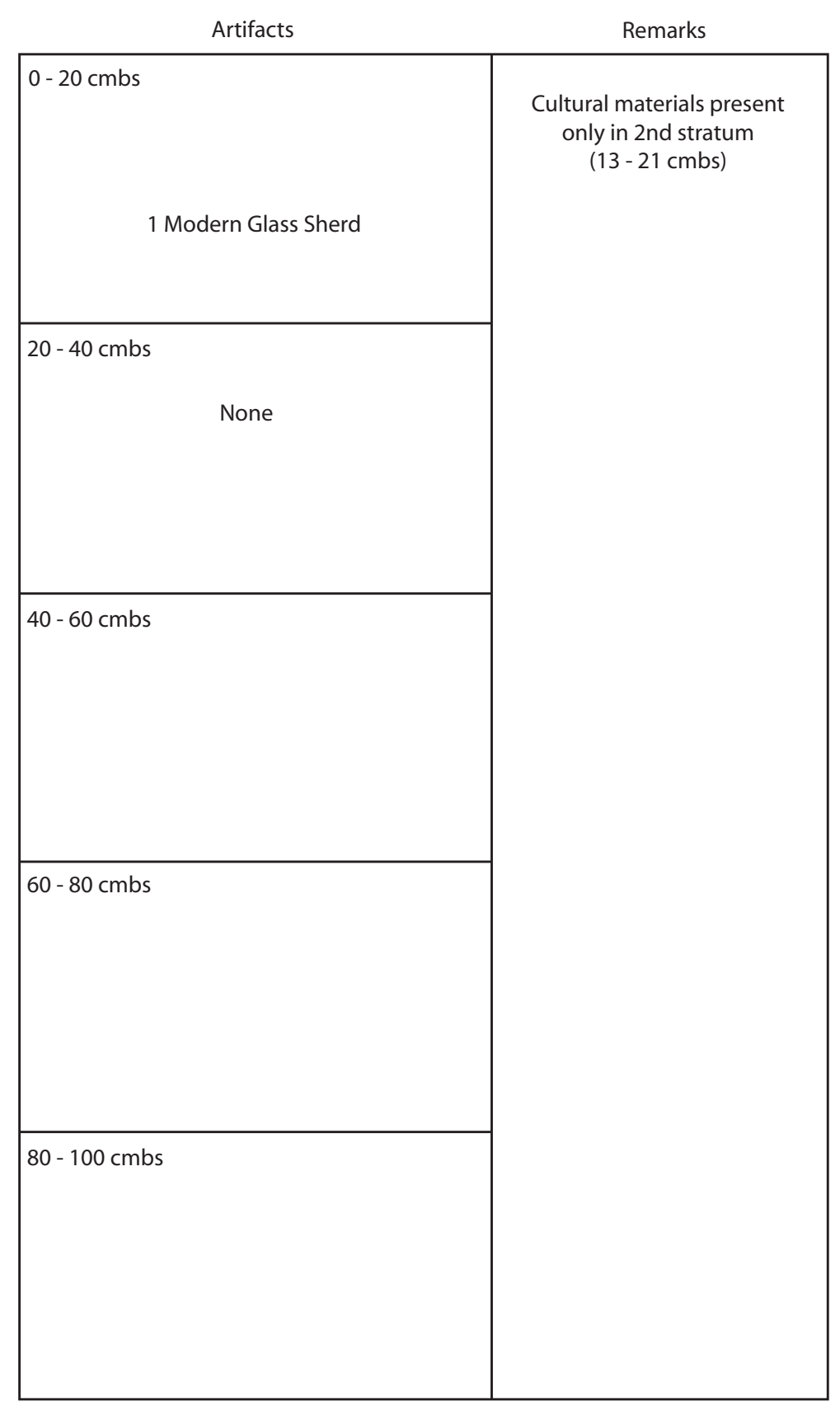




\section{Fairfield Lake State Park - TPWD \\ 41FT482 Shovel Test No. 6}

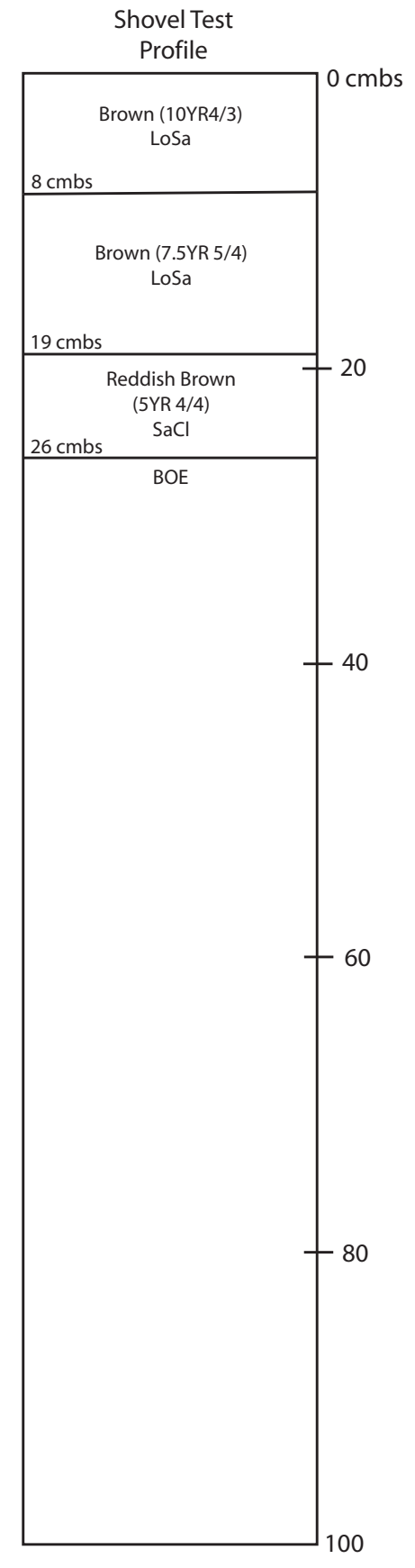

\begin{tabular}{|c|c|}
\hline Artifacts & Remarks \\
\hline $\begin{aligned} 0-20 \mathrm{cmbs} & \\
& 1 \text { Earthenware Sherd }\end{aligned}$ & $\begin{array}{l}\text { Cultural material present } \\
\text { only in } 2 \text { nd stratum } \\
\quad(8-19 \mathrm{cmbs})\end{array}$ \\
\hline $20-40 \mathrm{cmbs}$ & \\
\hline $40-60 \mathrm{cmbs}$ & \\
\hline $60-80 \mathrm{cmbs}$ & \\
\hline $80-100 \mathrm{cmbs}$ & \\
\hline
\end{tabular}


Fairfield Lake State Park - TPWD

41FT482 Shovel Test No. 7

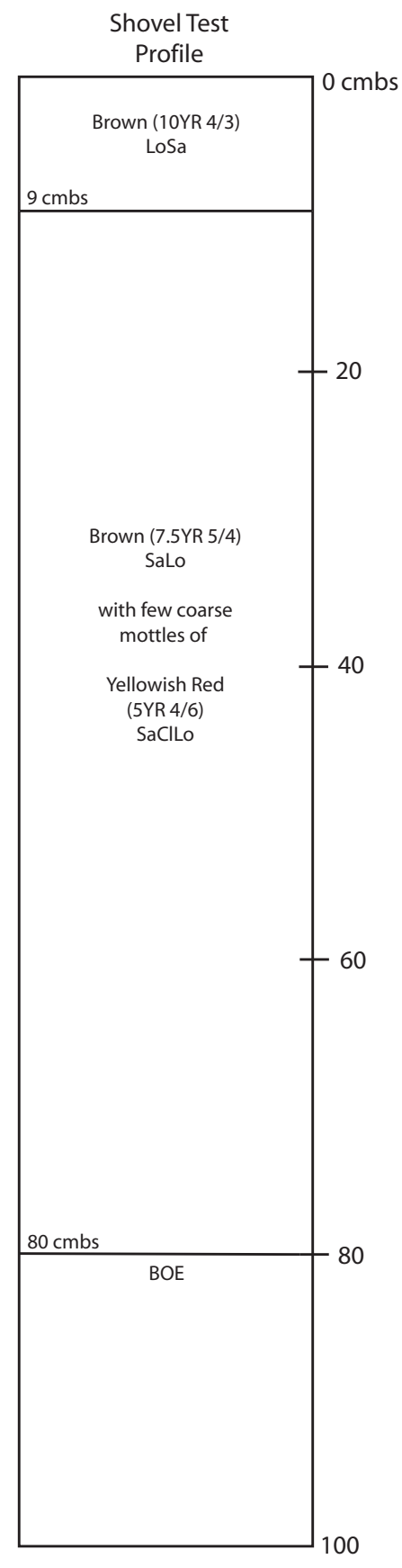

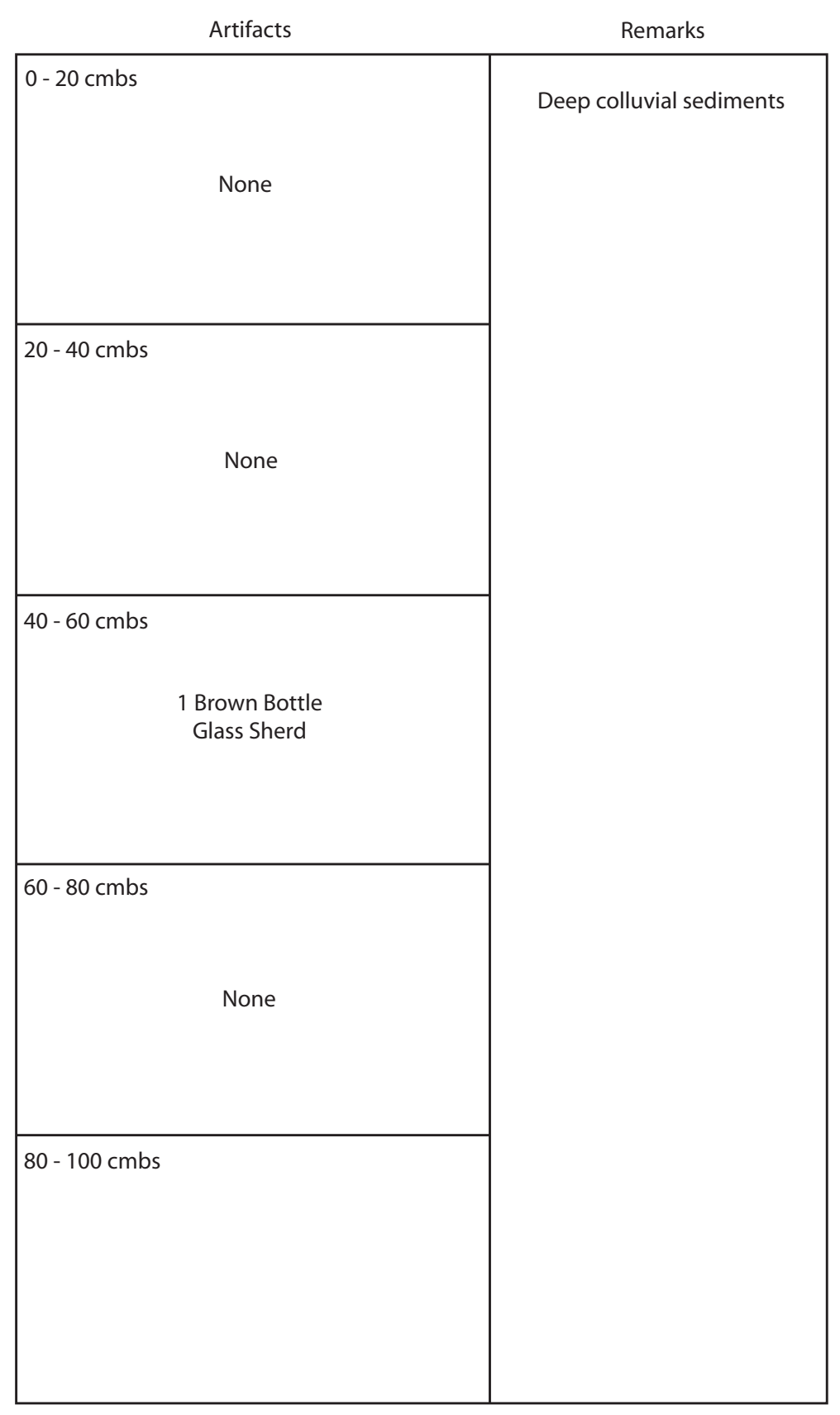


Fairfield Lake State Park - TPWD

41FT483 Shovel Test No. 1

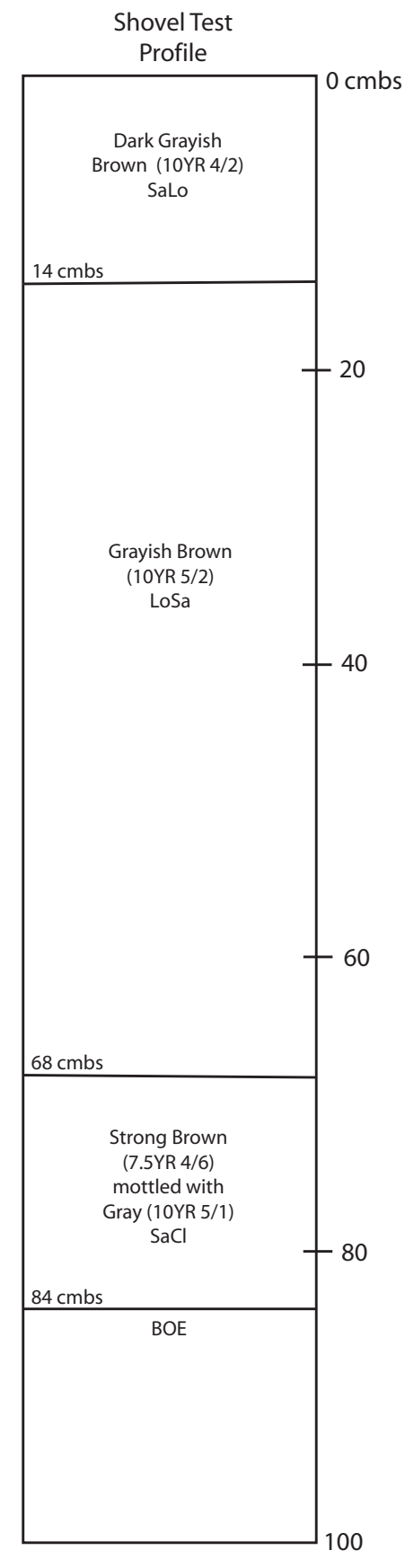

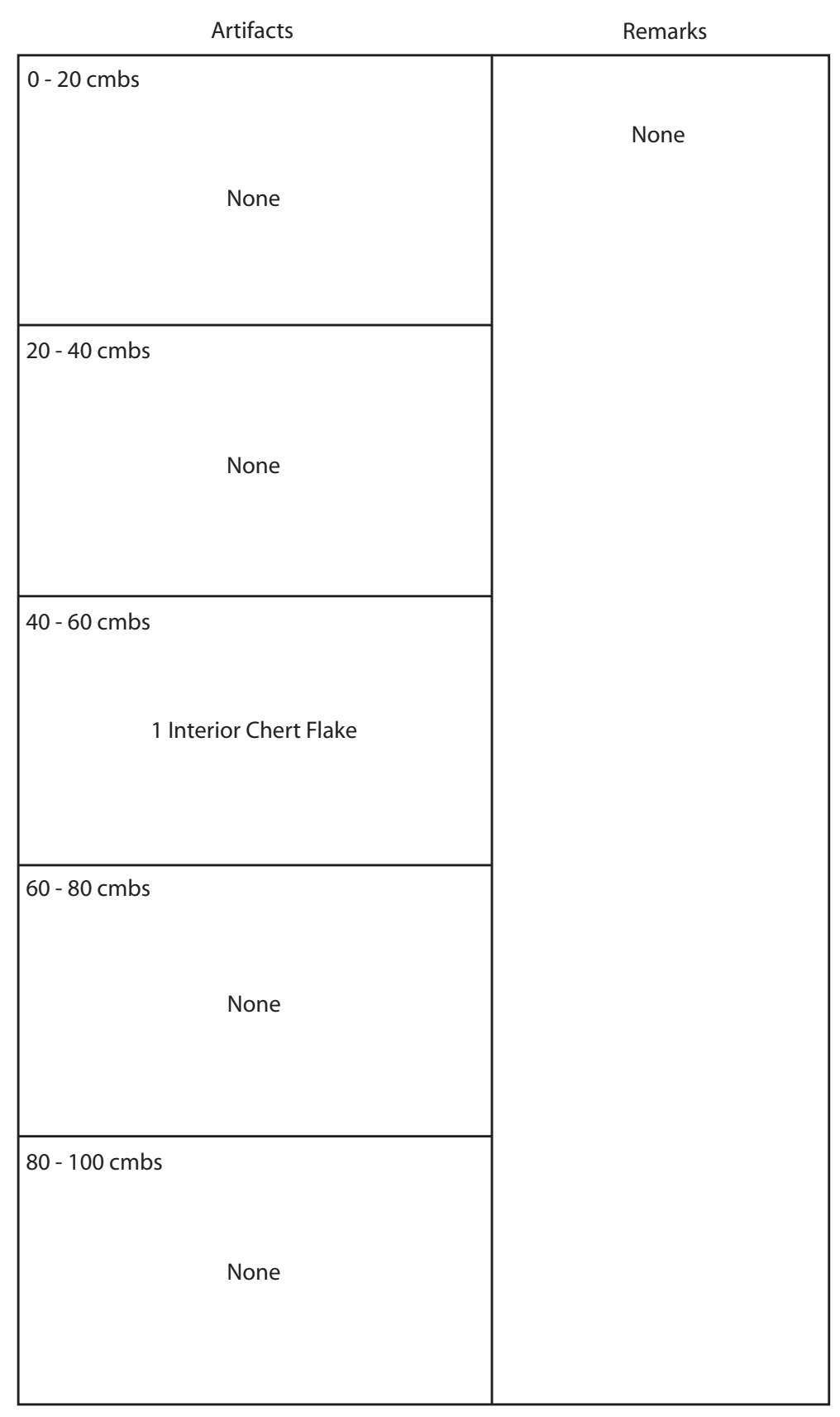


Fairfield Lake State Park - TPWD

41FT483 Shovel Test No. 2

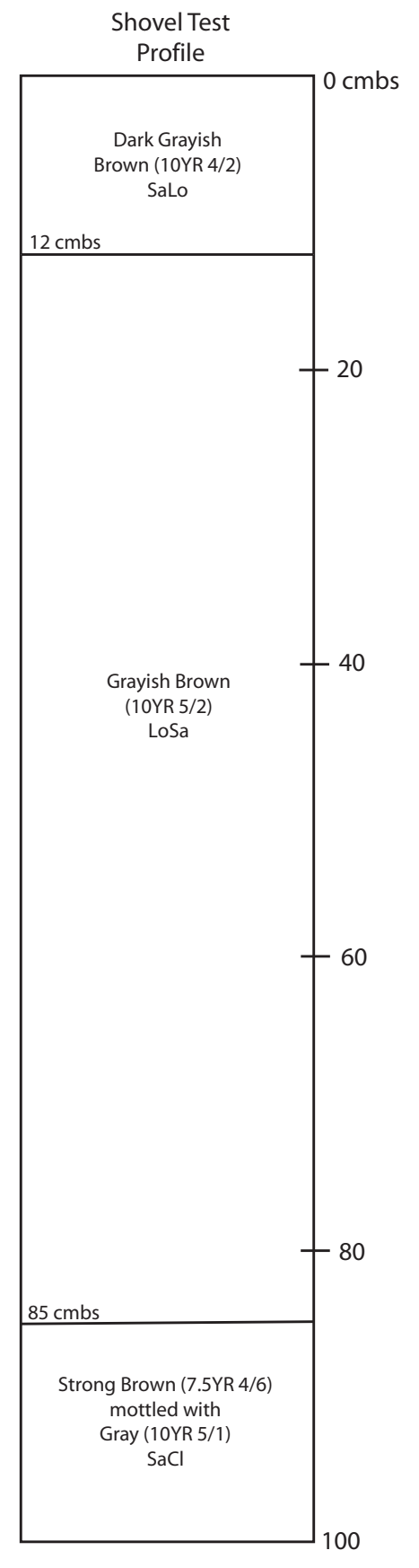

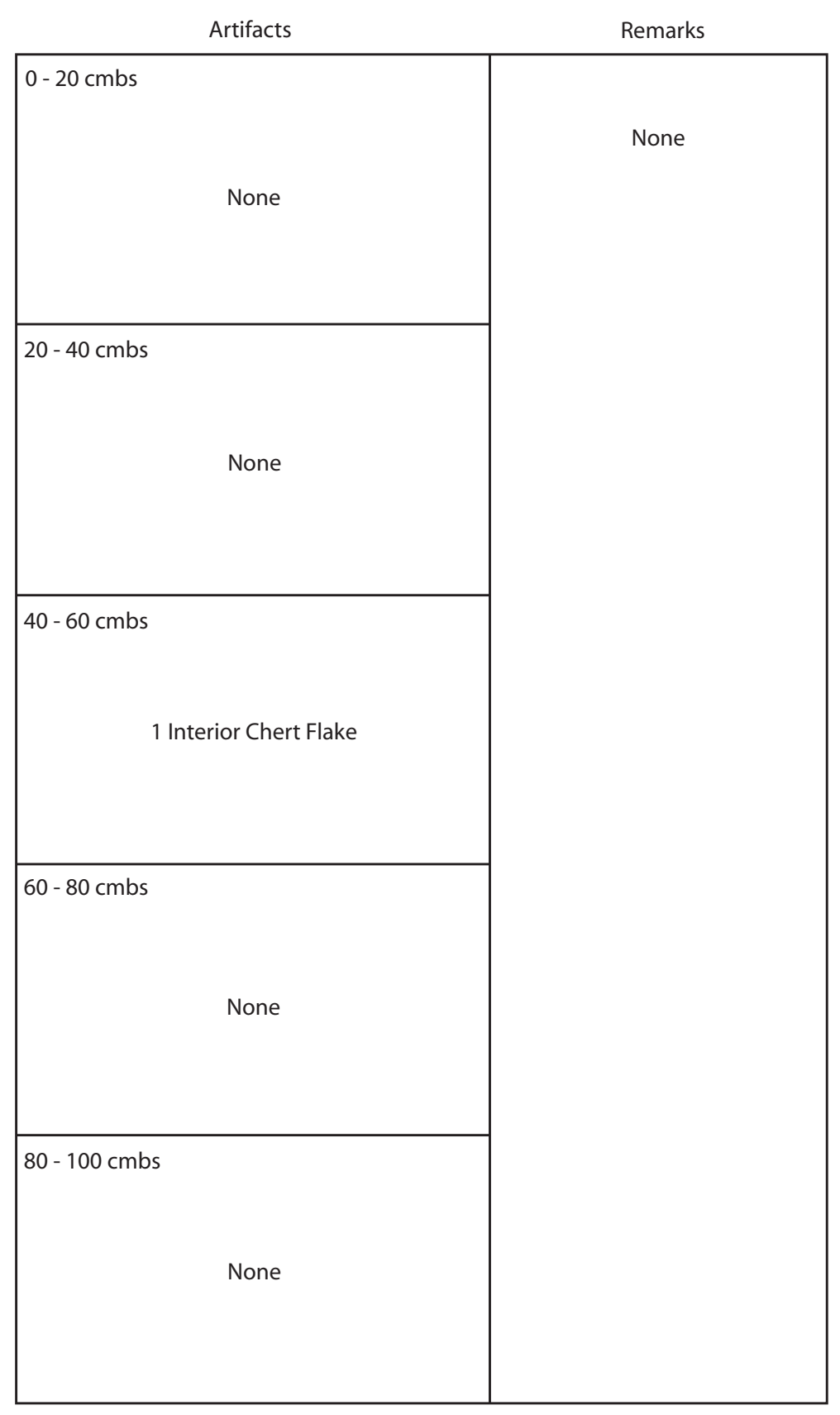


Fairfield Lake State Park - TPWD

41FT483 Shovel Test No. 3

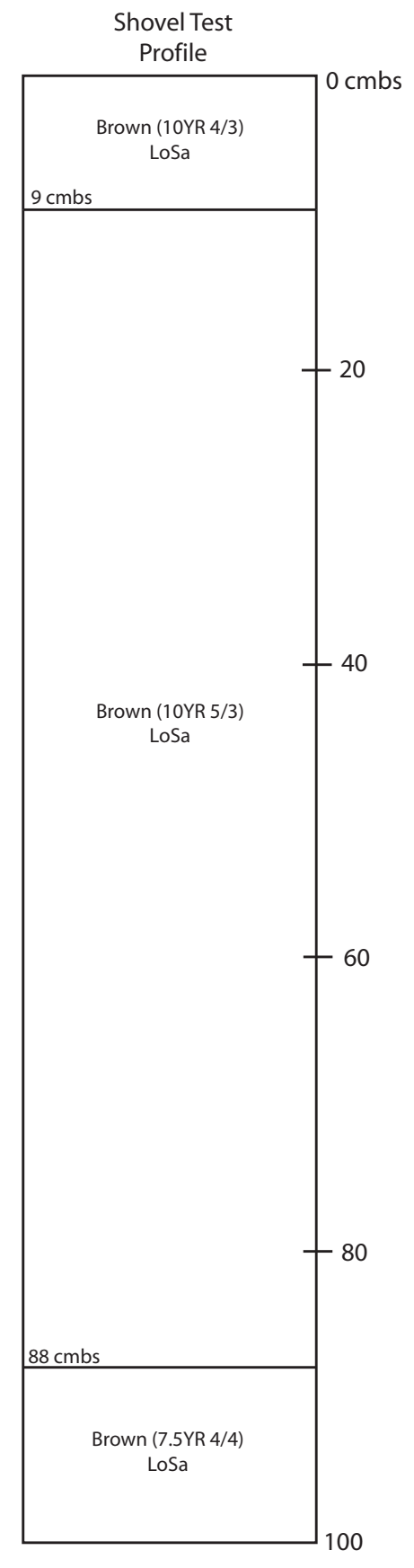

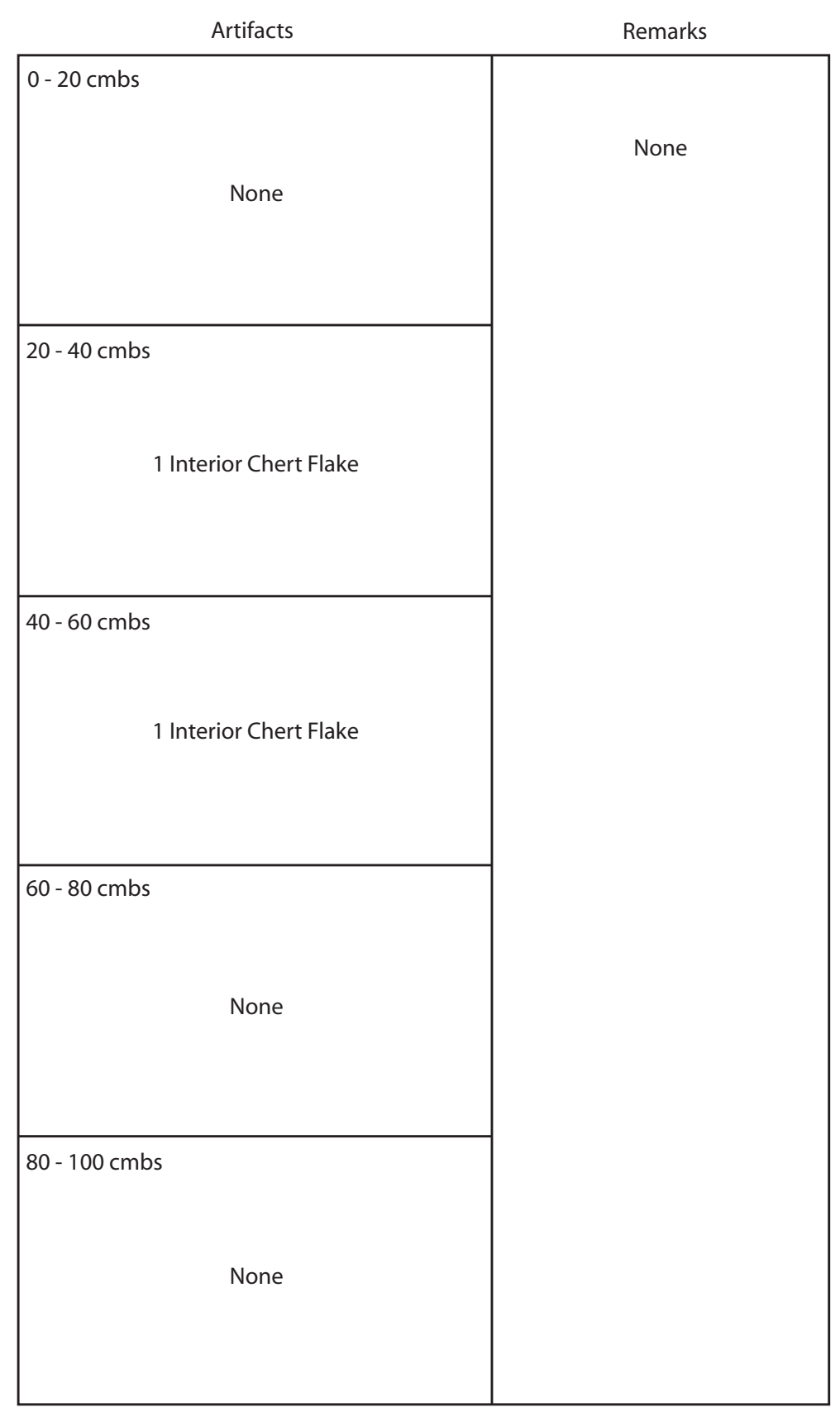


Fairfield Lake State Park - TPWD

41FT483 Shovel Test No. 4

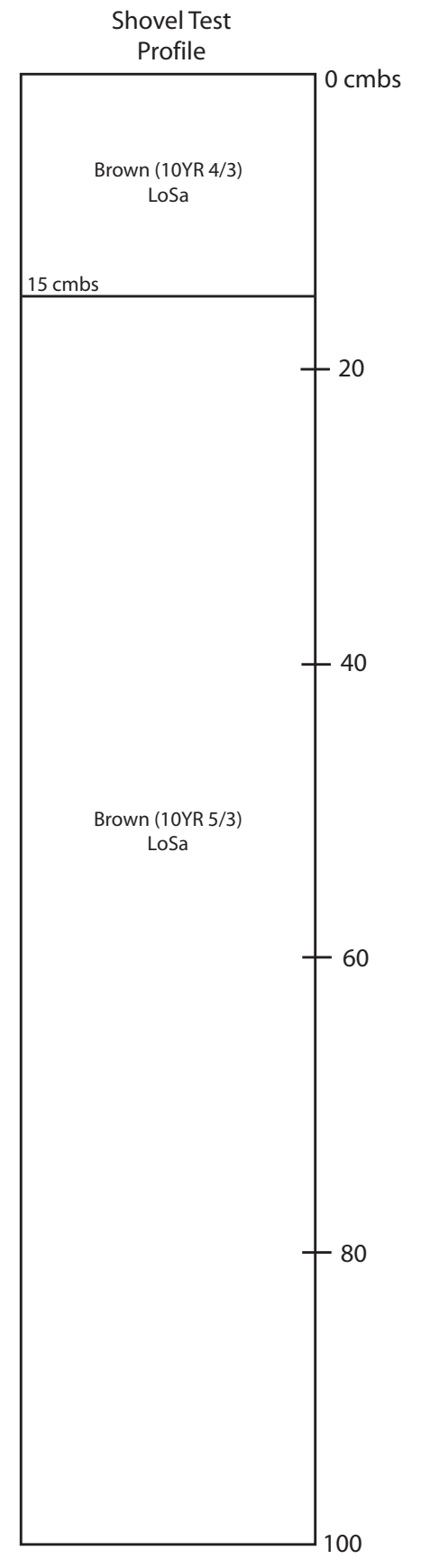

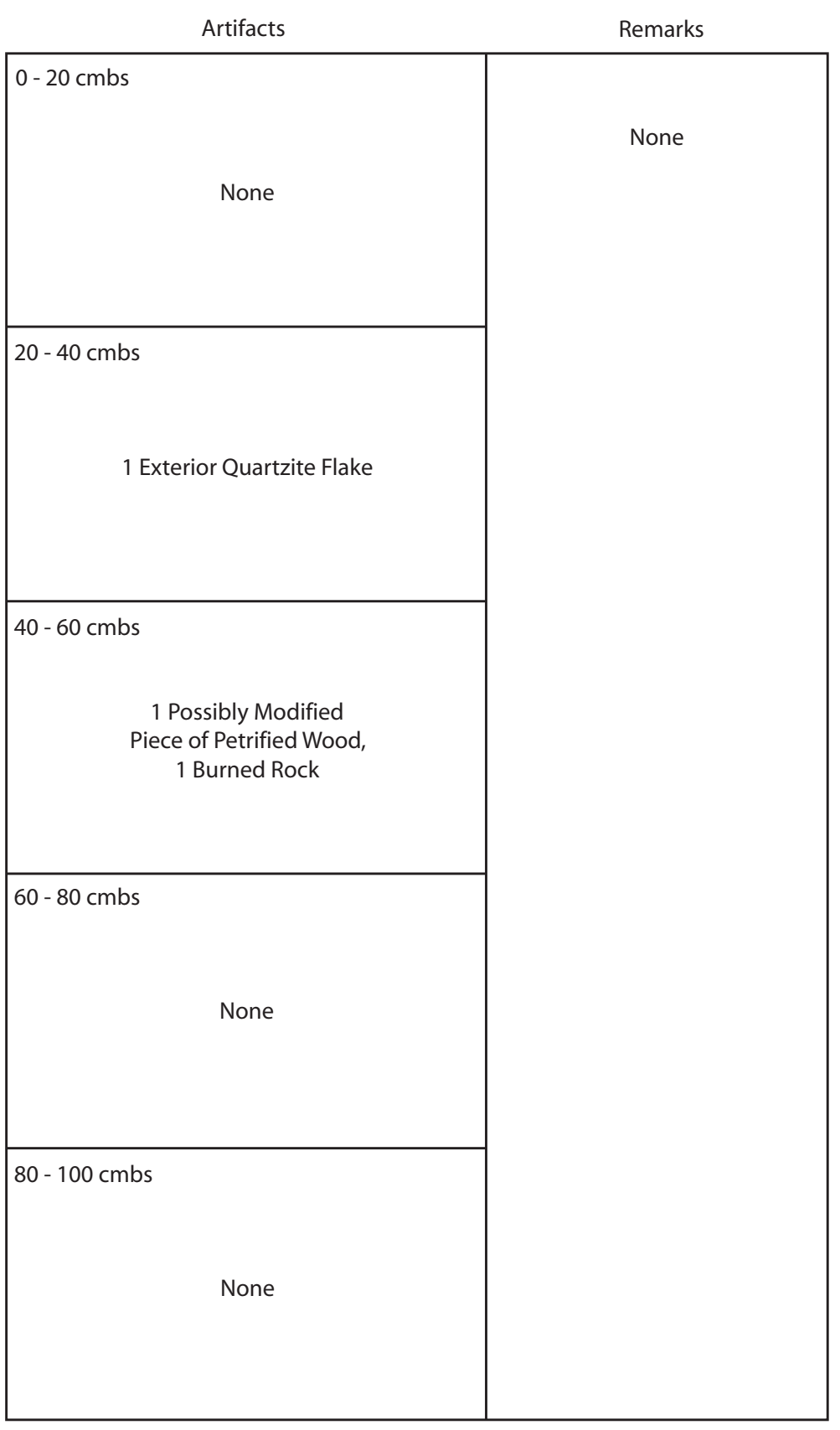



APENDIX B. REDACTED 